A Hydrostratigraphic Framework Model and Alternatives for the Groundwater Flow and Contaminant Transport Model of Corrective Action Unit 98: Frenchman Flat, Clark, Lincoln and Nye Counties, Nevada

\author{
Prepared for \\ U.S. Department of Energy \\ National Nuclear Security Administration \\ Nevada Site Office \\ Las Vegas, Nevada
}

Prepared by

Geotechnical Sciences Group

Bechtel Nevada

Las Vegas, Nevada

September 2005 


\section{DISCLAIMER STATEMENT}

Reference herein to any specific commercial product, process, or service by trade name, trademark, manufacturer, or otherwise, does not necessarily constitute or imply its endorsement, recommendation, or favoring by the U.S. Government or any agency thereof. The views and opinions of authors expressed herein do not necessarily state or reflect those of the U.S. Government or any agency thereof.

\section{AVAILABILITY STATEMENT}

Available to the public, in paper from-

U.S. Department of Commerce

National Technical Information Service

5285 Port Royal Road

Springfield, VA, 22161-0002

Telephone: 800.553.684 or 703.605 .6000

E-mail: orders@ntis.gov

Online ordering: http://www.ntis.gov/ordering.htm

Available electronically at http://www.osti.gov/bridge

Available for a processing fee to U.S. Department of Energy and its contractors, in paper, from-

\section{U.S. Department of Energy}

Office of Scientific and Technical Information

P.O. Box 62

Oak Ridge, TN, 37831-0062

Telephone: 865.576 .8401

Fax: 865.576.5728

E-mail: reports@adonis.osti.giv 


\section{A Hydrostratigraphic Framework Model and Alternatives for the Groundwater Flow and Contaminant Transport Model of Corrective Action Unit 98: Frenchman Flat, Clark, Lincoln and Nye Counties, Nevada}

Approved by: Lemenal 2. Stel cet Sigmrind L. Drellack, Jr. Task Leader,

Date: $9-22-05$

BN Underground Test Area Project

Approved by:

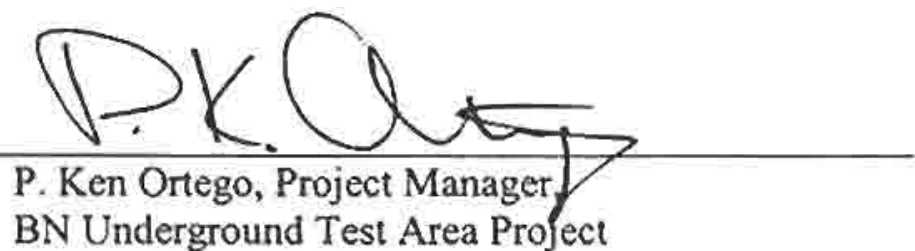

Date: $9 / 22 / 05$ 
This page intentionally left blank. 


\title{
A Hydrostratigraphic Model and Alternatives for the Groundwater Flow and Contaminant Transport Model of Corrective Action Unit 98: Frenchman Flat, Clark, Lincoln and Nye Counties, Nevada DOE/NV/11718--1064
}

\begin{abstract}
A new, revised three-dimensional (3-D) hydrostratigraphic framework model for Frenchman Flat was completed in 2004. The area of interest includes Frenchman Flat, a former nuclear testing area at the Nevada Test Site, and proximal areas. Internal and external reviews of an earlier (Phase I) Frenchman Flat model recommended additional data collection to address uncertainties. Subsequently, additional data were collected for this Phase II initiative, including five new drill holes and a 3-D seismic survey. These were integrated using EarthVision ${ }^{\circledR}$ to develop the new 3-D hydrostratigraphic framework model.

The model area is large (approximately 570 square kilometers) and geologically complex. A diverse set of geological and geophysical data collected over the past 40 years was utilized to develop a structural model and hydrostratigraphic classification system for the basin. The model consists of 73 faults and 17 hydrostratigraphic units. Formation of the basin appears to be related to the termination of the left-lateral Rock Valley fault system. Northeast-striking faults of the Rock Valley system in the southern portion of Frenchman Flat turn north and then northwest as the faults of the system flare out into an extensional imbricate fan along the eastern and northern margins of the basin. This has resulted in the basin being dropped down on the south, east and north, and filled with more than 2,740 meters of mostly Tertiary volcanic rocks and alluvium.
\end{abstract}

Forty-eight stratigraphic units in the model area were grouped into 17 hydrostratigraphic units based on their propensity toward aquifer or aquitard characteristics. The authors divided the alluvial section into 5 hydrostratigraphic units, including 3 aquifers and 2 confining units. The volcanic rocks are organized into 8 hydrostratigraphic units that include 4 aquifers and 4 confining units. The underlying pre-Tertiary rocks were divided into 4 hydrostratigraphic units, including 2 aquifers and 2 confining units. The model depicts the thickness, extent, and geometric relationships of these hydrostratigraphic units ("layers" in the model) along with the major structural features that control them (e.g. faults).

Some of the more significant differences between this hydrostratigraphic model and the Phase I model include a better constrained structural model that does not include a series of largedisplacement north-striking faults through the center of the basin and the testing areas. The depth of the lower carbonate aquifer is also better constrained and deeper in the vicinity of the testing areas in the current model. The current model also contains more hydrostratigraphic units based on new data and is consistent with the hydrostratigraphic classification system developed for the adjacent Yucca Flat CAU.

The complexity of the model area and the non-uniqueness of some of the interpretations incorporated into the base model made it necessary to address alternative interpretations for some of the major features in the model. Four of these alternatives were developed so they could be modeled in the same fashion as the base model.

This work was done in support of the U.S. Department of Energy, National Nuclear Security Administration Nevada Site Office in support of the Environmental Restoration Division's Underground Test Area Project. 
This page intentionally left blank. 


\section{Table of Contents}

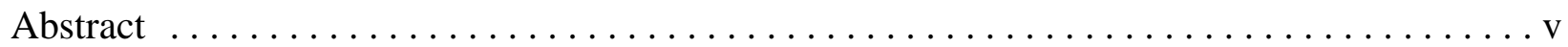

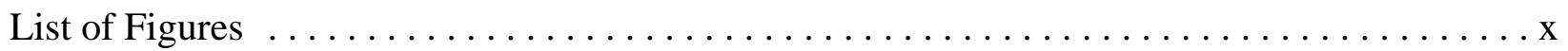

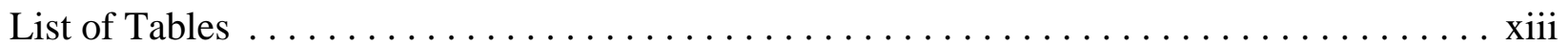

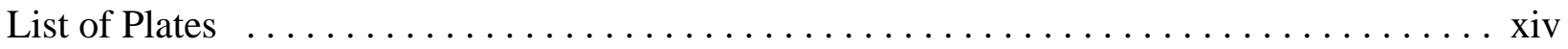

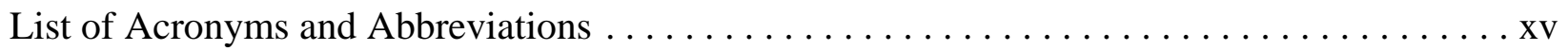

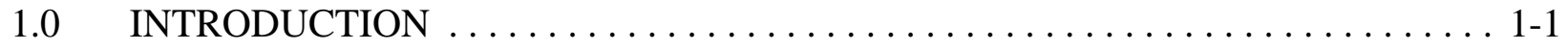

1.1 Background Information for Hydrostratigraphic Framework Model Task . . . . 1-1

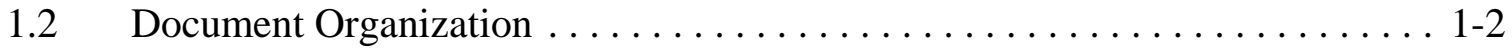

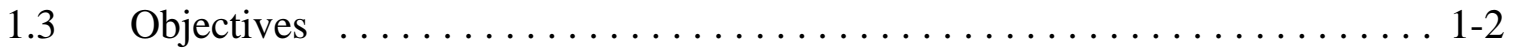

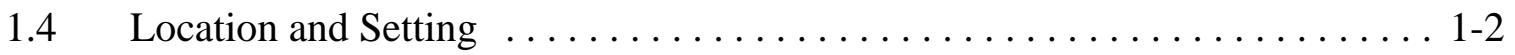

1.4.1 Underground Nuclear Tests in Frenchman Flat ............... 1-3

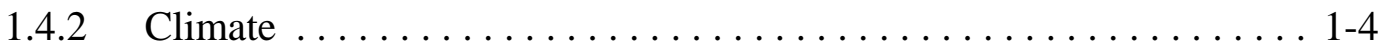

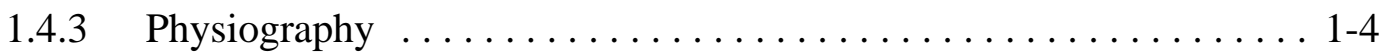

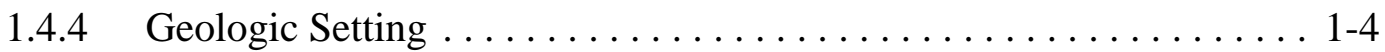

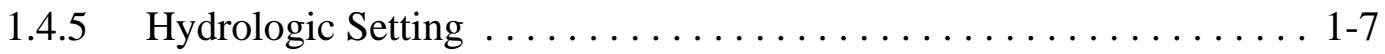

1.5 Previous UGTA Work $\ldots \ldots \ldots \ldots \ldots \ldots \ldots \ldots \ldots \ldots \ldots \ldots . . .1-8$

1.6 Summary of Differences Between the Initial Phase I Frenchman Flat Model

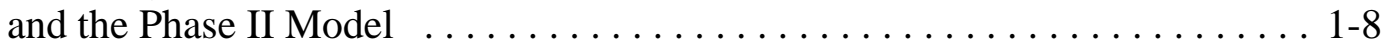

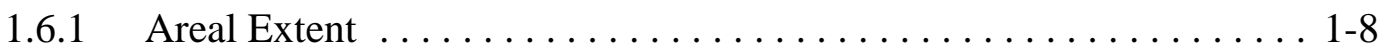

1.6.2 Structural Framework . . . . . . . . . . . . . . . . . . . . . . . 1-9

1.6.3 Basin Depth ................................ 1-9

1.6.4 Number of Hydrostratigraphic Units $\ldots \ldots \ldots \ldots \ldots \ldots \ldots \ldots . \ldots \ldots$

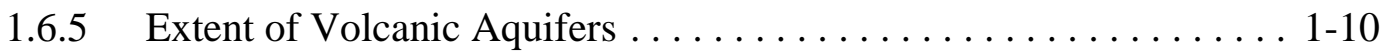

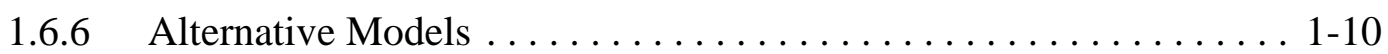

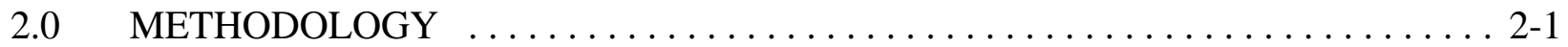

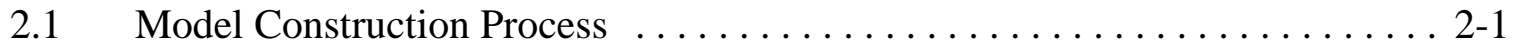

2.2 Determination of Model Area Boundaries ................... 2-3

2.3 Data, Interpretive Products, and Other Information Used in Model

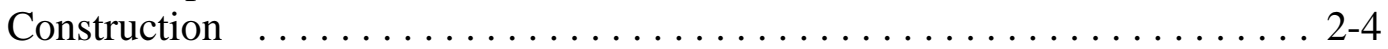

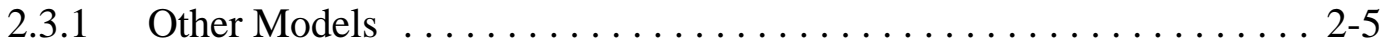

2.3.2 Existing Geological and Geophysical Maps $\ldots \ldots \ldots \ldots \ldots \ldots .2-5$

2.3.3 Drill Hole Data ............................. 2-7

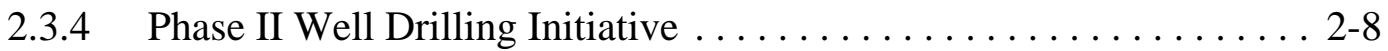

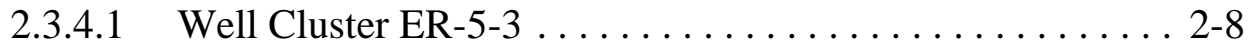

2.3.4.2 Well Cluster ER-5-4 .................... 2-9

2.3.5 Geophysical Data and Investigations ................. 2-10 


\section{Table of Contents (continued)}

2.3.5.1 Gravity Data .......................... 2-11

2.3.5.2 Ground Magnetic Data ................... 2-12

2.3.5.3 Aeromagnetic Data ........................ 2-12

2.3.5.4 Natural Source Magnetotelluric Survey ............ 2-13

2.3.5.5 Controlled-Source Audio-Frequency Magnetotelluric Survey .............................. 2-14

2.3.5.6 Other Resistivity Surveys ................... 2-15

2.3.5.7 Seismic Refraction Surveys ................. 2-15

2.3.5.8 2-D Seismic Reflection Survey $\ldots \ldots \ldots \ldots \ldots \ldots .2-15$

2.3.5.9 3-D Seismic Reflection Survey ................ 2-16

2.3.6 Alluvium Studies .......................... 2-17

2.3.6.1 Differentiation of the Older Alluvium . . . . . . . . . . 2-17

2.3.6.2 Reactive Secondary Mineral Study for Alluvium in North Central Frenchman Flat . . . . . . . . . . . . . . . . . 2-18

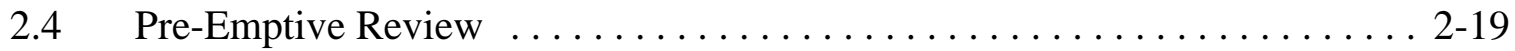

$2.5 \quad$ Model Construction .............................. 2-19

2.5.1 Use of Computer Software to Construct the Model ........... 2-20

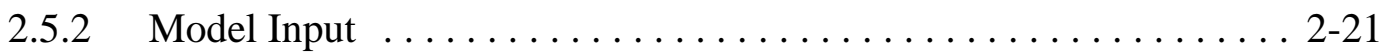

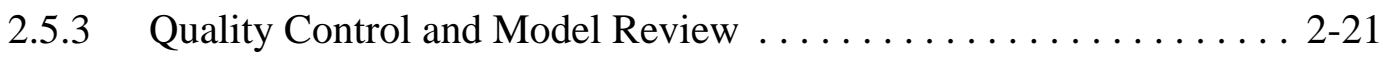

2.5.4 Alternative Models ............................. 2-22

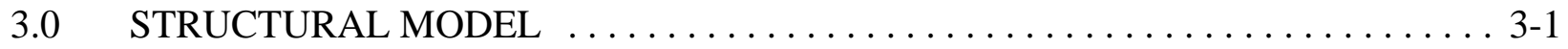

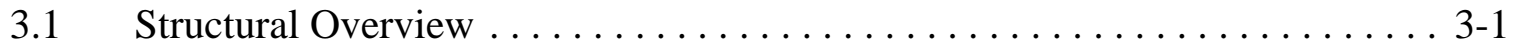

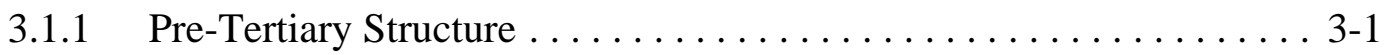

3.1.2 Development of Frenchman Flat Basin $\ldots \ldots \ldots \ldots \ldots \ldots \ldots . . \ldots \ldots .2$

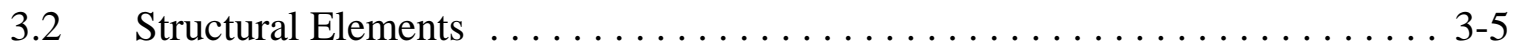

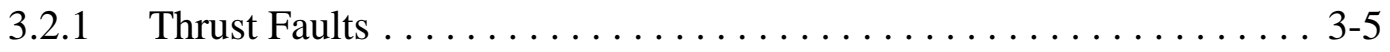

3.2.2 High-Angle Faults $\ldots \ldots \ldots \ldots \ldots \ldots \ldots \ldots \ldots \ldots \ldots . . \ldots \ldots$

3.2.3 Detachment Fault $\ldots \ldots \ldots \ldots \ldots \ldots \ldots \ldots \ldots \ldots \ldots \ldots \ldots \ldots \ldots \ldots \ldots \ldots$

3.3 Comparison with Phase I Model $\ldots \ldots \ldots \ldots \ldots \ldots \ldots \ldots \ldots \ldots \ldots \ldots \ldots \ldots$

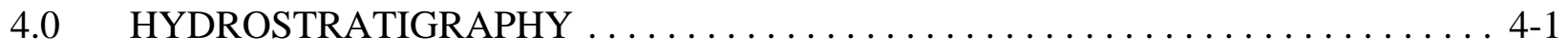

4.1 Development of the Hydrostratigraphic Classification System . . . . . . . . . 4 4-1

$4.2 \quad$ Stratigraphy of the Frenchman Flat Model Area .................. 4-2

4.3 Hydrogeologic Units for the Frenchman Flat Model Area $\ldots \ldots \ldots \ldots \ldots$. $4-3$

4.3.1 Alluvial HSUs $\ldots \ldots \ldots \ldots \ldots \ldots \ldots \ldots \ldots \ldots \ldots \ldots .7$

4.3.2 Volcanic HGUs $\ldots \ldots \ldots \ldots \ldots \ldots \ldots \ldots \ldots \ldots \ldots . . \ldots \ldots .4$

4.3.3 Pre-Tertiary HGUs $\ldots \ldots \ldots \ldots \ldots \ldots \ldots \ldots \ldots \ldots \ldots .4 .7$ 


\section{Table of Contents (continued)}

4.4 Hydrostratigraphic Units for the Frenchman Flat Model . . . . . . . . . . . 4-7

4.4.1 Alluvial Aquifers (AA,AA3, AA2, AA1) . . . . . . . . . . . 4-8

4.4.2 Playa Confining Units (PCU2T, PCU1U, PCU1L) . . . . . . . . . 4-12

4.4.3 Older Alluvial Aquifers (OAA, OAA1) . . . . . . . . . . . . . 4-13

4.4.4 Basalt Lava-Flow Aquifer (BLFA) . . . . . . . . . . . . . . . . 4-14

4.4.5 Timber Mountain Hydrostratigraphic Units . . . . . . . . . . . . . . . 4-14 4.4.5.1 Timber Mountain Welded-Tuff Aquifer (TM-WTA) . . . . 4-15

4.4.5.2 Timber Mountain Lower Vitric-Tuff Aquifer (TM-LVTA) 4-16

4.4.6 Upper Tuff Confining Unit (UTCU) . . . . . . . . . . . . . . . . . . 4-16

4.4.7 Topopah Spring Aquifer (TSA) . . . . . . . . . . . . . . 4 4-17

4.4.8 Lower Vitric-Tuff Aquifer (LVTA) . . . . . . . . . . . . . . . . 4-17

4.4.9 Wahmonie Confining Unit (WCU) . . . . . . . . . . . . . . . 4 4-18

4.4.10 Lower Tuff Confining Unit (LTCU) . . . . . . . . . . . . . . . . . 4-19

4.4.11 Volcaniclastic Confining Unit (VCU) . . . . . . . . . . . . . . . 4-20

4.4.12 Lower Carbonate Aquifer - Thrust Plate (LCA3) . . . . . . . . . . . 4-20

4.4.13 Upper Clastic Confining Unit (UCCU) . . . . . . . . . . . . . 4 4-21

4.4.14 Lower Carbonate Aquifer (LCA) . . . . . . . . . . . . . . 4-21

4.4.15 Lower Clastic Confining Unit (LCCU) . . . . . . . . . . . . . . 4-21

4.5 Relationship of Hydrostratigraphic Units and the Water Table . . . . . . 4 4-22

5.0 ALTERNATIVE SCENARIOS . . . . . . . . . . . . . . . . . . 5-1

5.1 Process of Addressing Alternatives to the Base Model . . . . . . . . . . 5-1

5.2 Alternative Models . . . . . . . . . . . . . . . . . . . . 5-11

5.2.1 Portray the Basalt as a Single, Continuous Lava Flow

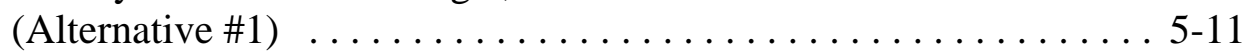

5.2.2 Remove the Detachment Fault (Alternative \#2) . . . . . . . . . . . 5-12

5.2.3 Juxtaposition of HSUs Along Faults (Alternative \#3) . . . . . . . . 5-12

5.2.4 Variations of the CP Thrust Fault in CP Basin (Alternative \#4) . . . 5 5-12

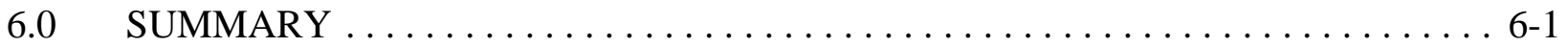

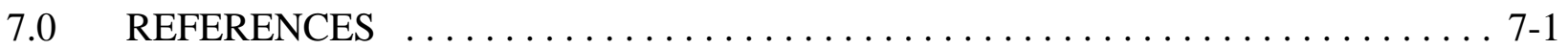

Appendix A - Geologic and Hydrostratigraphic Drill Hole Database for the Frenchman Flat Model Area

Appendix B - Graphical Presentations for Selected UGTA Wells in the Frenchman Flat Model Area Showing Stratigraphy, Lithology, Alteration, and Hydrogeologic Units

Appendix C - Hydrostratigraphic Profiles through the Frenchman Flat Model Area

Appendix D - 3-D Seismic Survey in Frenchman Flat 


\section{List of Figures}

\section{NOTE: Figures are located at the end of each section.}

Number

1-1 UGTA Corrective Action Unit (CAU) and Model Area Boundaries

1-2 Satellite Image of the Frenchman Flat Area Showing Physiographic Features and Locations of Underground Nuclear Tests

1-3 Color Relief Map Showing Locations of the Basin and Range Physiographic and Great Basin Hydrographic Provinces

1-4 Generalized Geologic Map of the Frenchman Flat Region

1-5 Natural Springs and Seeps on the Nevada Test Site

1-6 Groundwater Subbasins of the Nevada Test Site and Vicinity

2-1 3-D Display from EarthVision ${ }^{\circledR}$ of the Model Volume

2-2 Locations of Drill Holes in the Frenchman Flat Model Area

2-3 Elevation of Pre-Cenozoic Rocks beneath Frenchman Flat

2-4 Locations of Gravity Stations and Surface Magnetic Lines in the Frenchman Flat Model Area

2-5 Locations of Resistivity Receiver Stations and Lines in the Frenchman Flat Model Area

2-6 Locations of Seismic Surveys in the Frenchman Flat Model Area

2-7 Model Assessment Chart Comparing HSU Tops in Drill Holes with HSU Tops Generated by EarthVision ${ }^{\circledR}$ in the Base Model

3-1 Generalized Geologic Map of Frenchman Flat and Vicinity Showing the Conceptual Structural Model of the Basin

3-2 Structure Map for Top of Pre-Tertiary Rocks Generated from the EarthVision ${ }^{\circledR}$ Model

4-1 Simplified Stratigraphic Section for Frenchmen Flat

4-2 Correlation of Stratigraphic and Hydrostratigraphic Units of the Frenchman Flat Model Area

4-3 Block Model View Showing Hydrostratigraphic Units at the Surface within the Frenchman Flat Model Area

4-4 Block Model View Showing Basement Subcrop for the Frenchman Flat Model Area

4-5 Block Model View Showing Extent of the Alluvial Aquifer (AA) within the Frenchman Flat Model Area

4-6 Perspective View Showing Extent of the Playa Confining Unit (PCU2T) and the Older Alluvial Aquifer (OAA) within the Frenchman Flat Model Area 


\section{List of Figures (continued)}

\section{Number Title}

4-7 Schematic West-East Hydrostratigraphic Cross Section Through Central Frenchman Flat Showing Relationships of the Playa Confining Units and the Alluvial Aquifers

4-8 Perspective View Showing Extent of the Playa Confining Unit (PCU1U) and the Basalt Lava-Flow Aquifer (BLFA) within the Frenchman Flat Model Area

4-9 Perspective View Showing Extent of the Playa Confining Unit (PCU1L) and the Older Alluvial Aquifer (OAA1) within the Frenchman Flat Model Area

4-10 Schematic North-South Hydrostratigraphic Cross Section Showing Relationships Among the Alluvial Aquifers and the Basalt Lava-Flow Aquifer in Northern Frenchman Flat

4-11 Depth to Top of the Basalt Lava-Flow Aquifer (BLFA)

4-12 Schematic West-East Cross Section Across Northern Frenchman Flat Showing Variability in Hydrogeologic Character of the Timber Mountain Hydrostratigraphic Units

4-13 Block Model View Showing Extent of the Timber Mountain Welded-Tuff Aquifer (TM-WTA) within the Frenchman Flat Model Area

4-14 Schematic North-South Hydrostratigraphic Cross Section Showing Relationships Among the Volcanic HSUs in Northern Frenchman Flat

4-15 Depth to Top of the Timber Mountain Welded-Tuff Aquifer (TMWTA)

4-16 Block Model View Showing Extent of the Timber Mountain Lower Vitric-Tuff Aquifer within the Frenchman Flat Model Area

4-17 Depth to Top of the Timber Mountain Lower Vitric-Tuff Aquifer (TMLVTA)

4-18 Block Model View Showing Extent of the Upper Tuff Confining Unit (UTCU) within the Frenchman Flat Model Area

4-19 Block Model View Showing Extent of the Topopah Spring Aquifer (TSA) within the Frenchman Flat Model Area

4-20 Depth to Top of the Topopah Spring Aquifer (TSA)

4-21 Block Model View Showing Extent of the Lower Vitric-Tuff Aquifer (LVTA) within the Frenchman Flat Model Area

4-22 Depth to Top of the Lower Vitric-Tuff Aquifer (LVTA)

4-23 Block Model View Showing Extent of the Wahmonie Confining Unit (WCU) within the Frenchman Flat Model Area

4-24 Schematic West-East Hydrostratigraphic Cross Section Through South-Central Frenchman Flat Showing Relationship of the Wahmonie Confining Unit with other HSUs

4-25 Block Model View Showing Extent of the Lower Tuff Confining Unit (LTCU) within the Frenchman Flat Model Area 


\section{List of Figures (continued)}

Number

Title

4-26 Block Model View Showing Extent of the Volcaniclastic Confining Unit (VCU) within the Frenchman Flat Model Area

4-27 Block Model View Showing Extent of the Lower Carbonate Aquifer - Thrust Plate (LCA3) within the Frenchman Flat Model Area

4-28 Depth to Top of the Lower Carbonate Aquifer - Thrust Plate (LCA3)

4-29 Block Model View Showing Extent of the Upper Clastic Confining Unit (UCCU) within the Frenchman Flat Model Area

4-30 Block Model View Showing Extent of the Lower Carbonate Aquifer (LCA) within the Frenchman Flat Model Area

4-31 Depth to Top of the Lower Carbonate Aquifer (LCA)

4-32 Block Model View Showing Extent of the Lower Clastic Confining Unit (LCCU) within the Frenchman Flat Model Area

4-33 Map Showing HSUs at the Water Table within the Frenchman Flat Model Area

5-1 Comparison of the Basalt Lava-Flow Aquifer in the Base Model with Alternative Scenario \#1

5-2 Comparison of the Base Model with the No Detachment Fault Alternative (Alternative \#2)

5-3a Perspective View of the Base Model Showing Top of LCA and Location of Alternative \#3

5-3b Profiles Comparing Base Model with Alternative \#3

5-4 Comparison of the Base Model with the CP Basin Alternative (Alternative \#4)

\section{Hydrostratigraphic Profiles (Appendix C)}

\section{Profile Title}

A-A' West to East Hydrostratigraphic Profile A-A’ through North-Central Frenchman Flat at Well ER-5-3

B-B' West to East Hydrostratigraphic Profile through Central Frenchman Flat at Well ER-5-4

C-C’ North-Northeast to South-Southwest Hydrostratigraphic Profile C-C' through Wells ER-5-3 and ER-5-4, Central Frenchman Flat

D-D’ Northwest to Southeast Hydrostratigraphic Profile D-D’ through Well ER-5-4, Frenchman Flat

E-E' Northwest to Southeast Hydrostratigraphic Profile E-E' in Southwestern Frenchman Flat 


\section{List of Tables}

Number

Title

Page

1-1 Boundaries of the Frenchman Flat Model Area . . . . . . . . . . . . . . . . . 1-3

1-2 List of Underground Nuclear Tests Conducted in Frenchman Flat . . . . . . . . . . . 1-5

2-1 Geologic Quadrangle Maps (Scale 1:24,000) Used in Construction of the Frenchman Flat Hydrostratigraphic Framework Model . . . . . . . . . . . . . 2-6

2-2 Special Purpose Geologic Maps Used in Construction of the Frenchman Flat Hydrostratigraphic Framework Model $\ldots \ldots \ldots \ldots \ldots \ldots \ldots \ldots \ldots$. . . . . . . . . . . .

2-3 Miscellaneous Special Purpose Maps Used in Construction of the Frenchman Flat Hydrostratigraphic Framework Model $\ldots \ldots \ldots \ldots \ldots \ldots \ldots \ldots \ldots . \ldots \ldots$

4-1 Quaternary and Tertiary Stratigraphic Units of the Frenchman Flat Model Area . . . . 4-4

4-2 Pre-Tertiary Stratigraphic Units of the Frenchman Flat Model Area . . . . . . . . . . 4-5

4-3 Hydrogeologic Units of the Frenchman Flat Model . . . . . . . . . . . . . . . 4-6

4-4 Hydrostratigraphic Units of the Frenchman Flat Hydrostratigraphic Framework Model . . . . . . . . . . . . . . . . . . . . . . . 4-9

4-5 Correlation of Hydrostratigraphic Units of the Frenchman Flat Model and Earlier Models ... . . . . . . . . . . . . . . . . . . . . . . . . . . . . . . . . . . . 4 4-11

5-1 Abridged List of Alternative Scenarios for the Frenchman Flat 3-D Hydrostratigraphic Framework Model 


\section{List of Plates}

Plate 1 Geologic Map of Frenchman Flat and Vicinity

Plate 2 Hydrostratigraphic Unit Surface Map for the Frenchman Flat Model Area 


\section{List of Acronyms and Abbreviations}

\begin{tabular}{|c|c|}
\hline${ }^{\circ} \mathrm{C}$ & degrees Celsius \\
\hline${ }^{\circ} \mathrm{F}$ & degrees Fahrenheit \\
\hline $3-\mathrm{D}$ & three-dimensional \\
\hline AA & Alluvial aquifer; valley fill aquifer \\
\hline AA1 & Alluvial aquifer 1 \\
\hline AA2 & Alluvial aquifer 2 \\
\hline AA3 & Alluvial aquifer 3 \\
\hline BLFA & Basalt lava-flow aquifer \\
\hline $\mathrm{BN}$ & Bechtel Nevada \\
\hline CAU & Corrective Action Unit \\
\hline CSMAT & controlled-source audio-frequency magnetotelluric \\
\hline DEM & Digital Elevation Model \\
\hline DOE & U.S. Department of Energy \\
\hline ERMA® & Environmental Resources Management Applications System \\
\hline FFACO & Federal Facility Agreement and Consent Order \\
\hline $\mathrm{ft}$ & feet (foot) \\
\hline $\mathrm{gal} / \mathrm{min}$ & gallons per minute \\
\hline HGU & hydrogeologic unit \\
\hline HSU & hydrostratigraphic unit \\
\hline IT & International Technologies Corporation \\
\hline $\mathrm{km}$ & kilometer(s) \\
\hline $\mathrm{km}^{2}$ & square kilometers \\
\hline LANL & Los Alamos National Laboratory \\
\hline LCA & lower carbonate aquifer \\
\hline LCA3 & lower carbonate aquifer - thrust plate \\
\hline LCCU & lower clastic confining unit \\
\hline LFA & lava-flow aquifer \\
\hline LLNL & Lawrence Livermore National Laboratory \\
\hline lpm & liters per minute \\
\hline LTCU & lower tuff confining unit \\
\hline LTCU1 & lower tuff confining unit 1 \\
\hline LVTA & lower vitric tuff aquifer \\
\hline $\mathrm{m}$ & meter(s) \\
\hline Ma & Mega anna (i.e., million years ago) \\
\hline mi & mile(s) \\
\hline $\mathrm{mi}^{2}$ & square miles \\
\hline MT & magnetotelluric \\
\hline NAD & North American Datum \\
\hline
\end{tabular}




\section{List of Acronyms and Abbreviations (continued)}

NNSA/NSO U.S. Department of Energy, National Nuclear Security Administration Nevada Site Office

NTS Nevada Test Site

OAA older alluvium aquifer

OAA1 older alluvium aquifer 1

PCU2T playa confining unit

PCU1U older playa confining Unit 1 Upper

PCU1L older playa confining Unit 1 Lower

RWMS Radioactive Waste Management Site

SEM scanning electron microscope

SNJV Stoller-Navarro Joint Venture

SWNVF Southwestern Nevada Volcanic Field

TCU tuff confining unit

TD total depth

TMA Timber Mountain aquifer

TM-WTA Timber Mountain welded-tuff aquifer

TM-LVTA Timber Mountain lower-vitric aquifer

TSA Topopah Spring aquifer

TWG Technical Working Group

UCCU upper clastic confining unit

UGTA Underground Test Area

USGS U.S. Geological Survey

UTCU upper tuff confining unit

UTM Universal Transverse Mercator

VCU volcaniclastic confining unit

WCU Wahmonie confining unit

WTP weapons testing program

YMP Yucca Mountain Project

XRD X-ray diffraction

XRF $\quad x$-ray fluorescence 


\subsection{INTRODUCTION}

The Environmental Restoration Division of the U.S. Department of Energy (DOE), National Nuclear Security Administration Nevada Site Office (NNSA/NSO) initiated the Underground Test Area (UGTA) Project to investigate the extent of groundwater contamination at the Nevada Test Site (NTS) and surrounding areas due to past underground nuclear testing. The UGTA investigation focuses on the geology and hydrology of the NTS to estimate the direction and rate at which contaminants are transported by groundwater flow. This report describes the hydrostratigraphic framework model constructed for the Frenchman Flat area. This model will be used to develop models of groundwater flow and contaminant transport for the underground nuclear testing areas in Frenchman Flat.

\subsection{Background Information for Hydrostratigraphic Framework Model Task}

A regional three-dimensional (3-D) computer groundwater model (IT Corporation [IT], 1996a) was developed in the initial stages of the UGTA project to identify any immediate risk, and to provide a basis for developing more detailed models of specific nuclear testing areas designated as Corrective Action Units (CAU). The CAU-specific models, of which four are planned, geographically cover each of the six former NTS underground nuclear testing areas (Figure 1-1). CAU-specific groundwater-flow and contaminant-transport models will be used to determine contaminant boundaries based on the maximum extent of contaminant migration at specified regulatory limits. The models will also be used to refine a monitoring network to ensure public health and safety.

Construction of CAU-specific groundwater-flow and contaminant-transport models requires a hydrostratigraphic framework that depicts the character and extent of hydrostratigraphic units in three dimensions. CAU-specific framework models will provide modelers the ability to test a range of potential groundwater flow and contamination scenarios by allowing them to apply flow and transport algorithms and to vary parameters for each hydrostratigraphic unit. Thus, the framework model must reflect reality as well as it is known, but also must be suitable for mathematical manipulation. This report provides information about how the hydrostratigraphic framework model for the Frenchman Flat CAU was developed, presents a description of the model, and provides documentation of data sources used to produce the model. This document addresses only the hydrostratigraphic framework model. Separate data documentation packages containing detailed descriptions of the hydrologic modeling process, and other pertinent flow and transport information, have also been developed. 
The Frenchman Flat hydrostratigraphic framework model was developed by a multi-disciplinary team of scientists from the Bechtel Nevada (BN) Geotechnical Sciences group and StollerNavarro Join Venture (SNJV; the SNJV personnel were employed by the consortium, IT Corporation/Science Applications International Corporation/Geotrans at the beginning of this project). The team also received valuable input from scientists at the Los Alamos National Laboratory (LANL), Lawrence Livermore National Laboratory (LLNL), the U.S. Geological Survey (USGS), and the NNSA/NSO, and guidance from the NNSA/NSO UGTA Technical Working Group (TWG).

The model presented here consists of a base model and several alternatives. Because of the geologic complexity of the model area and non-unique interpretations incorporated into the base model, different geologic interpretations were developed for some of the more significant features in the model. These alternative models are intended to be tested by hydrologic modeling to evaluate the hydrologic impact of different geologic interpretations.

\subsection{Document Organization}

This section contains background information for the development of the Frenchman Flat hydrostratigraphic framework model, including location, setting, and previous work. Section 2.0 provides descriptions of the processes, methods, and data used to construct the model, including discussions of data obtained within the last five years specifically for the Frenchman Flat UGTA model. Section 3.0 presents a discussion of the structural elements of the model, and Section 4.0 describes all the hydrostratigraphic units included in the model. Alternative models are described in Section 5.0, Section 6.0 presents a document summary, and relevant references are listed in Section 7.0.

\subsection{Objectives}

The primary objective of the Frenchman Flat hydrostratigraphic modeling effort was to produce a 3-D hydrostratigraphic framework model that depicts the geometric relationships of hydrostratigraphic units (HSUs) and structural features in the Frenchman Flat model area. The effort also included development of alternative scenarios. The Frenchman Flat hydrostratigraphic framework model and alternative scenarios will be used to model groundwater flow and contaminant transport for the Frenchman Flat CAU.

\subsection{Location and Setting}

The hydrostratigraphic framework model for the Frenchman Flat area encompasses more than 570 square kilometers $\left(\mathrm{km}^{2}\right)$ (220 square miles $\left[\mathrm{mi}^{2}\right]$ ) in the southeastern part of the NTS (Figure 1-1). The model area is located approximately 113 kilometers (km) (70 miles [mi]) 
northwest of Las Vegas, Nevada, and includes lands managed by the U.S. Air Force (Nevada Test and Training Range; formerly known as the Nellis Air Force Range) and a co-use area of the Desert National Wildlife Refuge and the Nevada Test and Training Range, in addition to the southeastern portion of the NTS. The model area lies mostly in southern Nye County, Nevada, but also includes portions of southwestern Lincoln and northwestern Clark Counties, Nevada. The model area encompasses the Frenchman Flat CAU defined in the Federal Facility Agreement and Consent Order (FFACO; 1996 as amended), and additional areas surrounding the CAU that include important rock outcrop and drill hole data that help constrain geologic interpretations. The model area includes the Frenchman Flat topographic basin and portions of the adjacent highlands. The model area also includes portions of Yucca Flat and CP basins, located north and northwest of Frenchman Flat. The model has a north-south dimension of $30.0 \mathrm{~km}$ (19.1 mi) and an east-west dimension of $19.1 \mathrm{~km}$ (11.9 mi), and includes geologic units as deep as $5 \mathrm{~km}$ (3.1 mi) below mean sea level. Boundaries for the Frenchman Flat model area are listed in Table 1-1.

Table 1-1

Boundaries of the Frenchman Flat Model Area

\begin{tabular}{||l|c|c||}
\hline & $\begin{array}{c}\text { Central Nevada State } \\
\text { Planar Coordinates } \\
\text { (NAD 27; feet) })^{a, b}\end{array}$ & $\begin{array}{c}\text { Universal Transverse } \\
\text { Mercator (Zone 11) } \\
\text { (NAD 83; meters) }\end{array}$ \\
\hline \hline Northern Boundary, Along Northing & $\mathrm{N} \mathrm{805,460}$ & $\mathrm{N} \mathrm{4,091,000}$ \\
\hline Southern Boundary, Along Northing & $\mathrm{N} \mathrm{707,676}$ & $\mathrm{N} \mathrm{4,061,000}$ \\
\hline Western Boundary, Along Easting & $\mathrm{E} 679,585$ & $\mathrm{E} \mathrm{584,500}$ \\
\hline Eastern Boundary, Along Easting & $\mathrm{E} \mathrm{742,227}$ & $\mathrm{E} \mathrm{603,500}$ \\
\hline
\end{tabular}

a $\quad$ NAD $=1927$ North American Datum

b $\mathrm{N}=$ North; $\mathrm{E}=$ East

\subsubsection{Underground Nuclear Tests in Frenchman Flat}

The Frenchman Flat CAU includes the locations of all ten of the underground nuclear tests conducted in Frenchman Flat. All the tests are assumed to have generated contaminated groundwater because the tests were conducted in the saturated zone or within 100 meters (m) (325 feet [ft]) of the water table (DOE, 1999). The tests were conducted in two areas located in the northern and the central parts of Frenchman Flat (Figure 1-2). Seven underground nuclear tests were conducted in the northern part of the basin. One of these tests was located within the Tertiary volcanic rocks, below the alluvium, and the other six were conducted within the 
alluvium. Three tests were conducted in alluvium in the central part of the basin. Table 1-2 lists the underground nuclear tests conducted in Frenchman Flat, along with the designation of the emplacement hole, announced yield, depth of burial, location of the water table, and geologic unit at the working point (explosion point).

\subsubsection{Climate}

Frenchman Flat is located within the northern portion of the Mojave desert (DOE, 2004). Annual precipitation for Frenchman Flat is approximately 12 centimeters (5 inches) (DOE, 1998). Precipitation in the area is sporadic, typically falling as small amounts of rain or snow during isolated, short-duration winter and summer storms. Severe weather can occur in the region, usually in the form of summer thunderstorms with intense lightning, strong winds, and localized heavy rainfall. Daily temperatures range from -3 to 12 degrees Celsius $\left({ }^{\circ} \mathrm{C}\right.$ ) (27 to 54 degrees Fahrenheit $\left[{ }^{\circ} \mathrm{F}\right]$ ) in January, and from $17^{\circ}$ to $36^{\circ} \mathrm{C}\left(63^{\circ}\right.$ to $97^{\circ} \mathrm{F}$ ) in July (DOE, 1998).

\subsubsection{Physiography}

Frenchman Flat is an intermontane basin located in the northern portion of the Basin and Range physiographic province (Figure 1-3). The basin is bounded on the north by Massachusetts Mountain and French Peak, on the east by the Ranger Mountains and Buried Hills, on the south by the Spotted Range, and on the west by the Wahmonie Hills (Figure 1-2). The sparsely vegetated valley floor slopes gently toward a central playa (dry lake bed). Ground level elevations range from $938 \mathrm{~m}$ (3,078 ft) above sea level at the playa, to over 1,463 m (4,800 ft) in the nearby surrounding mountains.

\subsubsection{Geologic Setting}

Frenchman Flat is a Cenozoic-age basin formed in response to basin-and-range extension. Rocks exposed in the highlands around the margins of Frenchman Flat include Paleozoic sedimentary rocks and Cenozoic volcanic and tuffaceous sedimentary rocks (Hinrichs and McKay, 1965; Poole, 1965; Poole et al., 1965; Hinrichs, 1968; McKeown et al., 1976; Barnes et al., 1982). Paleozoic sedimentary rocks are exposed along the south and east margins of Frenchman Flat (Figure 1-4 and Plate 1), and consist mostly of carbonate rocks ranging in age from Cambrian to Mississippian. The Paleozoic rocks show contractional deformation most likely related to generally east-directed thrusting during the Mesozoic. However, contractional 
Table 1-2

List of Underground Nuclear Tests Conducted in Frenchman Flat ${ }^{a}$

\begin{tabular}{|c|c|c|c|c|c|c|c|}
\hline $\begin{array}{c}\text { Emplacement } \\
\text { Hole } \\
\text { Designation }\end{array}$ & Test Name & $\begin{array}{l}\text { Date } \\
\text { of Test }\end{array}$ & $\begin{array}{c}\text { Yield } \\
\text { (kilotons) }\end{array}$ & $\begin{array}{c}\text { Depth of } \\
\text { Burial } \\
\text { (meters [feet]) }\end{array}$ & $\begin{array}{l}\text { Static Water } \\
\text { Level Depth } \\
\text { (meters [feet]) }\end{array}$ & $\begin{array}{l}\text { Working Point } \\
\text { Geology }\end{array}$ & $\begin{array}{c}\text { Estimated } \\
\text { Alluvium } \\
\text { Thickness } \\
\text { (meters [feet]) } \\
\end{array}$ \\
\hline \multicolumn{8}{|c|}{ Northern Test Area } \\
\hline$U-5 i$ & DERRINGER & 9/12/1966 & 7.8 & $255(837)$ & $335(1,100)$ & Alluvium & $305(1,000)$ \\
\hline U-5k & MILK SHAKE & 3/25/1968 & $<20$ & $265(868)$ & 286 (939) & Alluvium & $500(1,640)$ \\
\hline$U-11 b$ & PIN STRIPE & 4/25/1966 & $<20$ & $269(970)$ & $349(1,146)$ & Volcanic Rocks & $58(190)$ \\
\hline U-11c & NEW POINT & $12 / 13 / 1966$ & $<20$ & $239(785)$ & $299(980)^{c}$ & Alluvium & $478(1,570)$ \\
\hline $\mathrm{U}-11 \mathrm{e}$ & DIANA MOON & 8/27/1968 & $<20$ & $242(794)$ & $305(1,000)^{\mathrm{C}}$ & Alluvium & $366(1,200)$ \\
\hline U-11f & MINUTE STEAK & 9/12/1969 & $<20$ & $265(868)$ & $302(990)^{c}$ & Alluvium & $427(1,400)$ \\
\hline $\mathrm{U}-11 \mathrm{~g}$ & DIAGONAL LINE & $11 / 24 / 1971$ & $<20$ & $264(867)$ & $301(988)^{c}$ & Alluvium & $341(1,120)$ \\
\hline \multicolumn{8}{|c|}{ Central Test Area } \\
\hline U-5a & WISHBONE & 2/18/1965 & $<20$ & $175(574)$ & $N A^{d}$ & Alluvium & $590(1,935)$ \\
\hline$U-5 b$ & DILUTED WATERS & 6/16/1965 & $<20$ & $193(632)$ & $213(700)^{c}$ & Alluvium & $400(1,312)$ \\
\hline U-5e & CAMBRIC & $5 / 14 / 1965$ & 0.75 & 295 (967) & $213(700)$ & Alluvium & $576(1,890)$ \\
\hline
\end{tabular}
a Sources: DOE (2000b) and Marsh (1992)
b Drellack, 1997
c Estimated
d Not Available 
deformation has been overprinted by extensive extensional deformation related to basin-andrange extension during the Cenozoic. The Paleozoic rocks dip generally south and east away from Frenchman Flat.

Volcanic rock exposures include Miocene-age tuffs of generally rhyolitic composition erupted from large calderas located $40 \mathrm{~km}$ ( $25 \mathrm{mi}$ ) northwest of Frenchman Flat. These rocks dominate the highlands north and northwest of Frenchman Flat and dip south and southeast into the basin. The highlands bordering Frenchman Flat on the west are composed of intermediate-composition tuffs, lavas, and debris flows from the Wahmonie volcanic center located west of Frenchman Flat. These rocks are also Miocene in age, and generally dip southeastward into the basin. Numerous normal faults related to basin-and-range extension offset the volcanic rocks.

Tuffaceous sedimentary rocks occur within a rather narrow, linear, northeast-trending depositional area that generally corresponds to the topographic axis of the basin (Prothro and Drellack, 1997). These rocks are exposed along the southern margin of the basin, where they consist of a diverse assemblage of fluvial and lacustrine sandstone and mudrock, freshwater limestone, conglomerate, and volcanic tuff. The tuffaceous sedimentary rocks appear to be partly coeval with the older volcanic rocks, and thus likely interfinger with the volcanic rocks beneath northern portion of Frenchman Flat. Tuffaceous sedimentary rocks exposed along the southern margin of Frenchman Flat dip north into the basin.

Drilling and geophysical data from Frenchman Flat indicate that many of the rock units exposed along the margins of the basin are present beneath Frenchman Flat, but have been buried by thick aprons of alluvial debris shed from the exposed highlands during basin development. At its deepest point the basin is filled with approximately 1,500 m (5,000 ft) of Miocene to Quaternary alluvium that overlies approximately 1,300 m (4,300 ft) of Tertiary volcanic and tuffaceous sedimentary rocks.

Frenchman Flat lies within the Walker Lane Belt, a northwest-trending zone of complex structural deformation consisting of basin-and-range extensional fault blocks, strike-slip faults, and detachment faults (Stewart, 1998). The basin is just north of the Las Vegas Valley shear zone, a west-northwest-trending zone of right-lateral strike-slip faulting. The Rock Valley fault zone is located southwest of the basin. This zone is a system of left-lateral strike-slip faulting that trends northeast into the southern portion of the model area. 


\subsubsection{Hydrologic Setting}

Frenchman Flat is located within the Great Basin hydrographic province (Figure 1-3). The Great Basin is characterized by internal drainage, and consists of numerous hydrographically closed topographic basins, such as Frenchman Flat and Yucca Flat. Streams in the Frenchman Flat vicinity are ephemeral, flowing only in response to precipitation events. Runoff is conveyed through normally dry washes toward the topographically lowest part of the basin, and collects on the Frenchman Flat playa. The Frenchman Flat model area also includes portions of the Yucca Flat playa, northwest of Frenchman Flat. Although there are 24 known springs or seeps on the NTS (Hansen et al., 1997), no springs or seeps occur within the boundaries of the Frenchman Flat model area (Figure 1-5).

The NTS, including the Frenchman Flat model area, is located within the Death Valley regional groundwater flow system, one of the major hydrologic subdivisions of the southern Great Basin (Waddell et al., 1984; Laczniak et al., 1996). Groundwater in the NTS region is conveyed within several groundwater flow-system sub-basins within the Death Valley regional flow system (Figure 1-6). The Frenchman Flat model area is located within the Ash Meadows sub-basin. Recharge areas for the Death Valley groundwater system are the higher mountain ranges of central and southern Nevada, where there can be significant precipitation and snow-melt. Groundwater flow is generally from these upland areas to natural discharge areas located to the south and southwest. Potentiometric data indicate that the groundwater flow direction in the Frenchman Flat area is to the south-southwest, toward discharge areas in Amargosa Valley and Death Valley.

The depth to groundwater in Frenchman Flat ranges from $282.6 \mathrm{~m}(927 \mathrm{ft})$ in the northern portion of the basin at Well ER-5-3, to $215.7 \mathrm{~m}$ (708 ft) at Well ER-5-4 \#2 in the central portion of Frenchman Flat. At Well TW6-C at the southern end of Yucca Flat, the depth to groundwater is $470.6 \mathrm{~m}(1,544 \mathrm{ft})$. In CP Basin groundwater occurs at $256.6 \mathrm{~m}(842 \mathrm{ft})$ below the ground surface at Well WW6-4A. These depths correspond to elevations (above mean sea level) of 734.6 m (2,410 ft) in northern Frenchman Flat, 738.8 m (2,424 ft) in central Frenchman Flat, $724.5 \mathrm{~m}(2,377 \mathrm{ft})$ at the southern end of Yucca Flat, and $842.5 \mathrm{~m}$ (2,764 ft) in CP Basin.

Six water supply wells within the Frenchman Flat model area provide both potable and nonpotable water to the NTS. These wells include Water Wells 5b, 5c,and UE-5c in Frenchman Flat, WW6-4 and WW6-4a in CP Basin, and TWC6 at the southern end of Yucca Flat. 


\subsection{Previous UGTA Work}

Results from the Value of Information Analysis conducted for the Frenchman Flat area (IT, 1997) indicated that existing geologic data were sufficient to develop a CAU-specific hydrostratigraphic framework model for Frenchman Flat. The process of building a 3-D hydrostratigraphic model of Frenchman Flat began in October 1997, and an interim report containing supporting documentation for the completed model, hereafter referred to as the Phase I Frenchman Flat model, was issued in August 1998 (IT, 1998).

Technical reviews of the Phase I Frenchman Flat model were conducted by the UGTA TWG modeling subcommittee and an outside technical peer-review panel (IT, 1999b). These reviewers' major concerns regarding the Phase I hydrostratigraphic framework model were that existing data were inadequate to define the hydrostratigraphic framework, and that the model contained several uncertainties. Recommendations for resolving these concerns included performing additional data-collection activities such as drilling and seismic reflection, and assessing uncertainties in the model through the use of alternative models. As a result of the reviews, the Frenchman Flat Corrective Action Investigation Plan (DOE, 2000a) and a Phase II data acquisition initiative was conducted that included the completion of 5 new drill holes, a 3-D seismic reflection survey, and other studies referenced throughout this report. In addition, alternative models were developed to address uncertainties associated with hydrologically significant interpretations in the base model.

Rebuilding of the Phase I hydrostratigraphic framework model for Frenchman Flat using the new Phase II data began in October 2003. The methods used to rebuild the Phase I Frenchman Flat model were similar to those used to construct the UGTA Pahute Mesa - Oasis Valley framework model (BN, 2002). This effort included the use of EarthVision ${ }^{\circledR}$ modeling software which was not available during construction of the initial Frenchman Flat Phase I model.

\subsection{Summary of Differences Between the Initial Phase I Frenchman Flat Model and the Phase II Model}

The initial Phase I Frenchman Flat model and the current Phase II model differ in six main attributes: areal extent of the model; structural framework; depth of the basin; number of HSUs; extent of the volcanic aquifers; and the development of alternative models. The following paragraphs describe the differences between the two models for each attribute.

\subsubsection{Areal Extent}

The northern boundary of the Phase II model is $4.37 \mathrm{~km}(2.7 \mathrm{mi})$ farther north than the northern boundary of the Phase I model. This provides more overlap between the Frenchman Flat 
framework model and the Yucca Flat framework model (currently under construction). The extension of the northern boundary of the Phase II model makes the Phase II model $83 \mathrm{~km}^{2}$ $\left(32 \mathrm{mi}^{2}\right.$ ) larger in areal extent than the Phase I model.

\subsubsection{Structural Framework}

The initial Frenchman Flat Phase I base model incorporated a conceptual structural model developed by Grauch and Hudson (1995) that was based primarily on interpretation of gravity and aeromagnetic data. The Phase II model uses a new structural model based on a rigorous analysis of all the geologic and geophysical data, including data from the Phase II data acquisition. As a result, the structural models for the Phase I and Phase II Frenchman Flat hydrostratigraphic framework models, although similar in the general concept of basin development, differ considerably in detail. Both structural models depict a series of basinforming faults that flare out of the Rock Valley fault zone. However, the Phase I structural model depicted these faults as north-trending, down-to-the-west normal faults that produced a series of east-tilted half grabens beneath the central portion of Frenchman Flat. The Phase II structural model confines the basin-forming faults to the east side of Frenchman Flat, and models the faults as curving to the northwest. This results in a single, deep, east-tilted half graben beneath the central portion of Frenchman Flat, and a structural platform beneath the northern portion of the basin. The Phase II model also includes a detachment fault beneath the northern portion of Frenchman Flat. This structural feature was not part of the Phase I model.

\subsubsection{Basin Depth}

Data collected during the Frenchman Flat Phase II data acquisition clearly show that the Frenchman Flat basin is deeper than originally depicted in the Phase I framework model. In the vicinity of underground nuclear test locations in the central portion of Frenchman Flat, preTertiary rocks, which form the regional aquifer, are more than 1,000 $\mathrm{m}$ (3,000 ft) deeper in the Phase II model. Beneath northern Frenchman Flat, in the vicinity of Well Cluster ER-5-3, preTertiary rocks are approximately $380 \mathrm{~m}$ (1,250 ft) deeper in the Phase II model.

The greater depth to pre-Tertiary rocks in the Phase II model results in greater thicknesses of the overlying alluvial and volcanic deposits. Alluvial deposits in the Phase II framework model are more than $100 \mathrm{~m}$ (330 ft) thicker in northern portion of the basin, and more than $800 \mathrm{~m}(2,600 \mathrm{ft})$ thicker beneath central Frenchman Flat. Likewise, Tertiary-age volcanic rocks are $300 \mathrm{~m}$ $(980 \mathrm{ft})$ thicker beneath northern Frenchman Flat and $600 \mathrm{~m}$ (1,970 ft) thicker beneath the central portion of the basin. 


\subsubsection{Number of Hydrostratigraphic Units}

The Phase II hydrostratigraphic framework model for Frenchman Flat includes 17 HSUs versus 9 HSUs in Phase I model. The increase in the number of HSUs in the Phase II model is mainly the result of subdividing original Phase I HSUs based on new information from the Phase II data acquisition initiative. These subdivisions provide more detail in the model, as well as consistency with the hydrostratigraphic system under development for Yucca Flat where much more subsurface data is available.

\subsubsection{Extent of Volcanic Aquifers}

Phase II data from Well Cluster ER-5-4 (see Section 2.3.4.2) and the 3-D seismic survey (Section 2.3.5.9) clearly indicate that the volcanic aquifers in the Phase II model (i.e., Timber Mountain welded-tuff aquifer [TM-WTA], Timber Mountain vitric-tuff aquifer [TM-LVTA], and Topopah Spring aquifer [TSA]) are more extensive than the hydrostratigraphically equivalent Timber Mountain aquifer (TMA), that was originally modeled in the Phase I model. The volcanic aquifers in the Phase II model extend from outcrops in the hills north of Frenchman Flat southward to the central portion of the basin, pinching out south of Well Cluster ER-5-4. In the Phase I model the TMA was confined to the northern portion of Frenchman Flat, and thus was not present beneath the central portion of the basin.

\subsubsection{Alternative Models}

Although alternative interpretations were considered and described narratively in the Phase I model, they were not developed as independent models. The Phase II model also provides for four alternative models. Each alternative model contains a different interpretation of a nonunique or poorly constrained interpretation of a certain aspect of the base model that was judged to be hydrologically significant. Eight other alternative interpretations were judged to be better assessed during flow and transport modeling instead of developing separate framework models. 


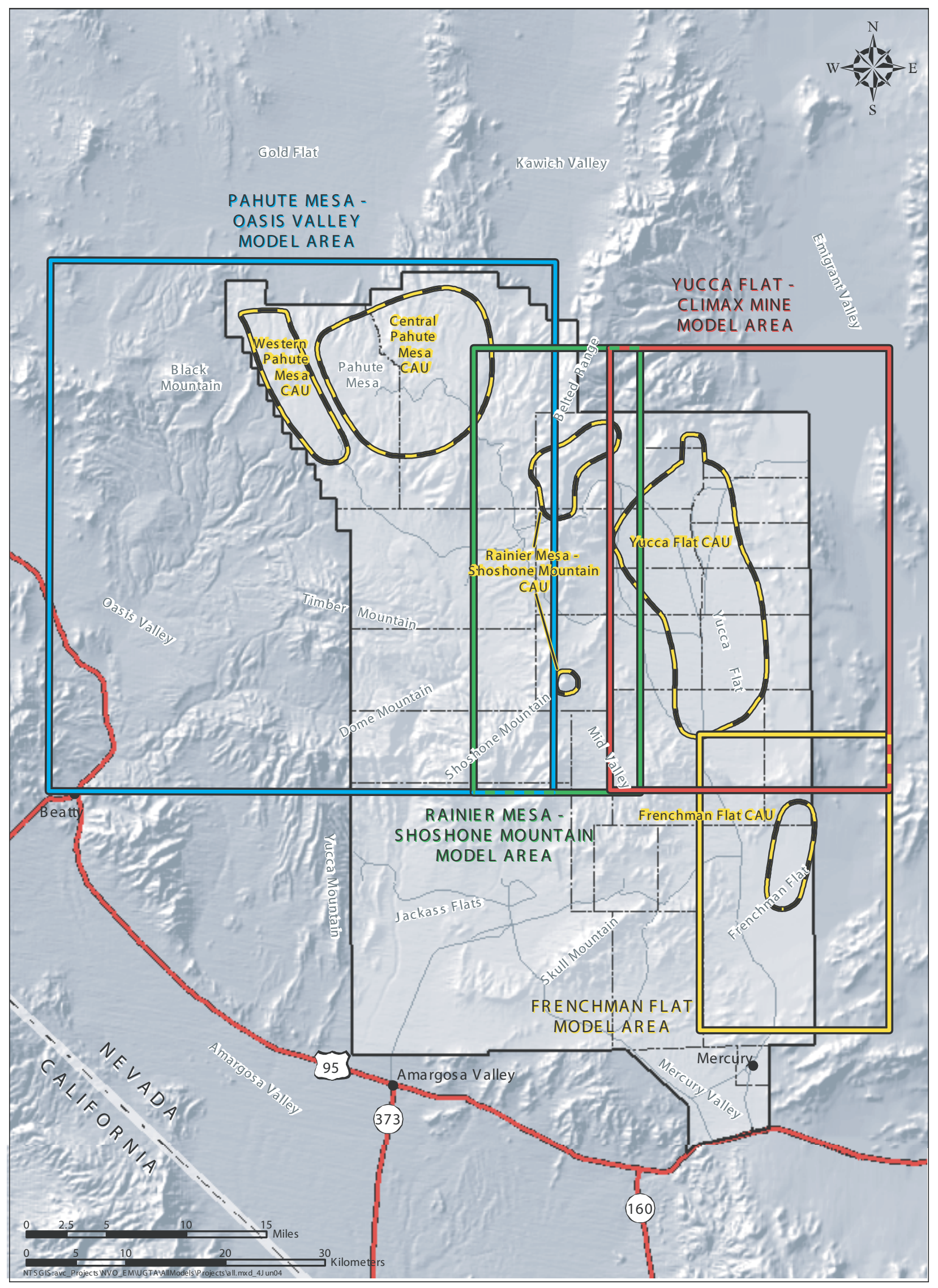

Figure 1-1

UGTA Corrective Action Unit (CAU) and Model Area Boundaries 


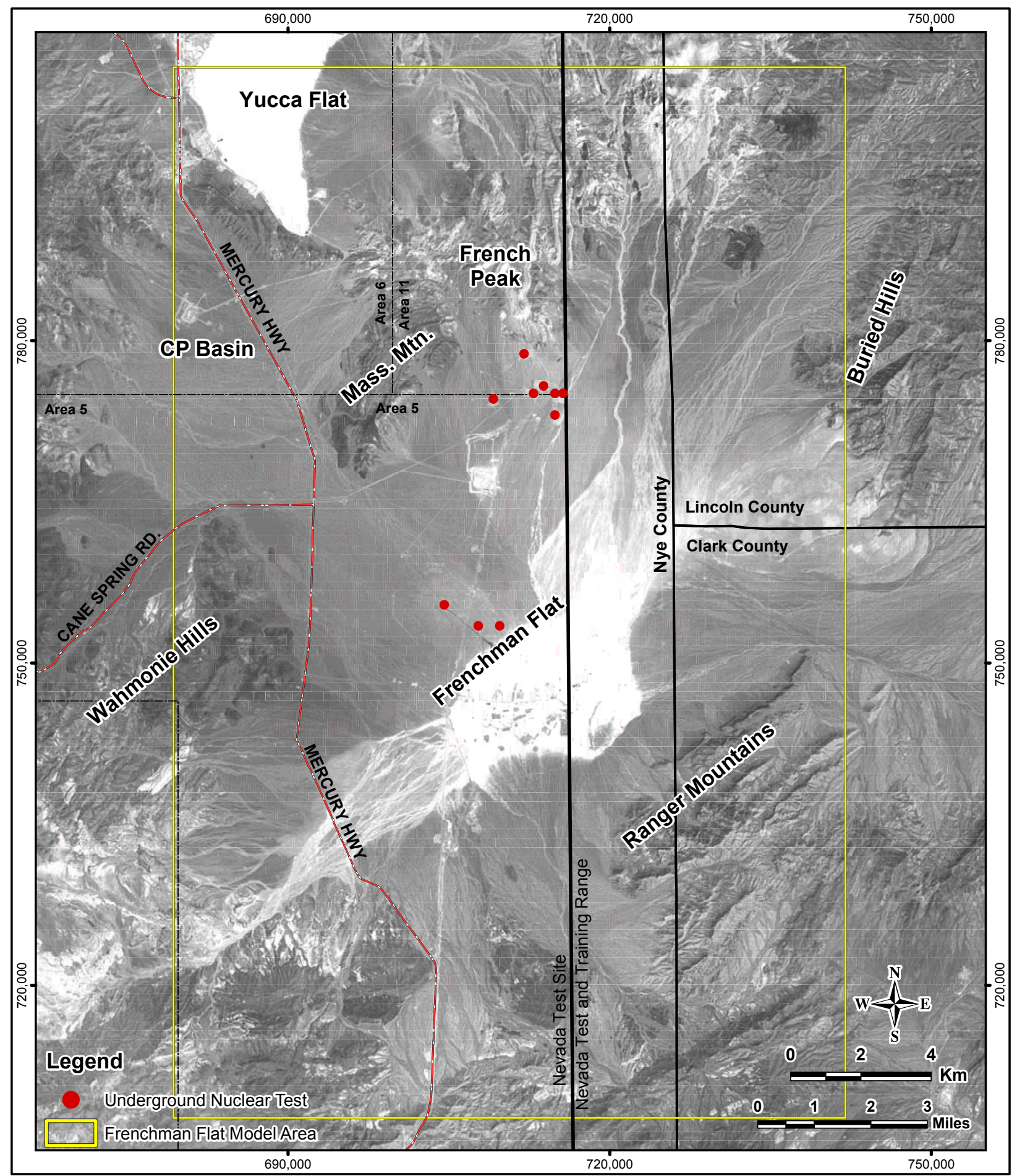

Figure 1-2

Satellite Image of the Frenchman Flat Area Showing Physiographic Features and Locations of Underground Nuclear Tests 


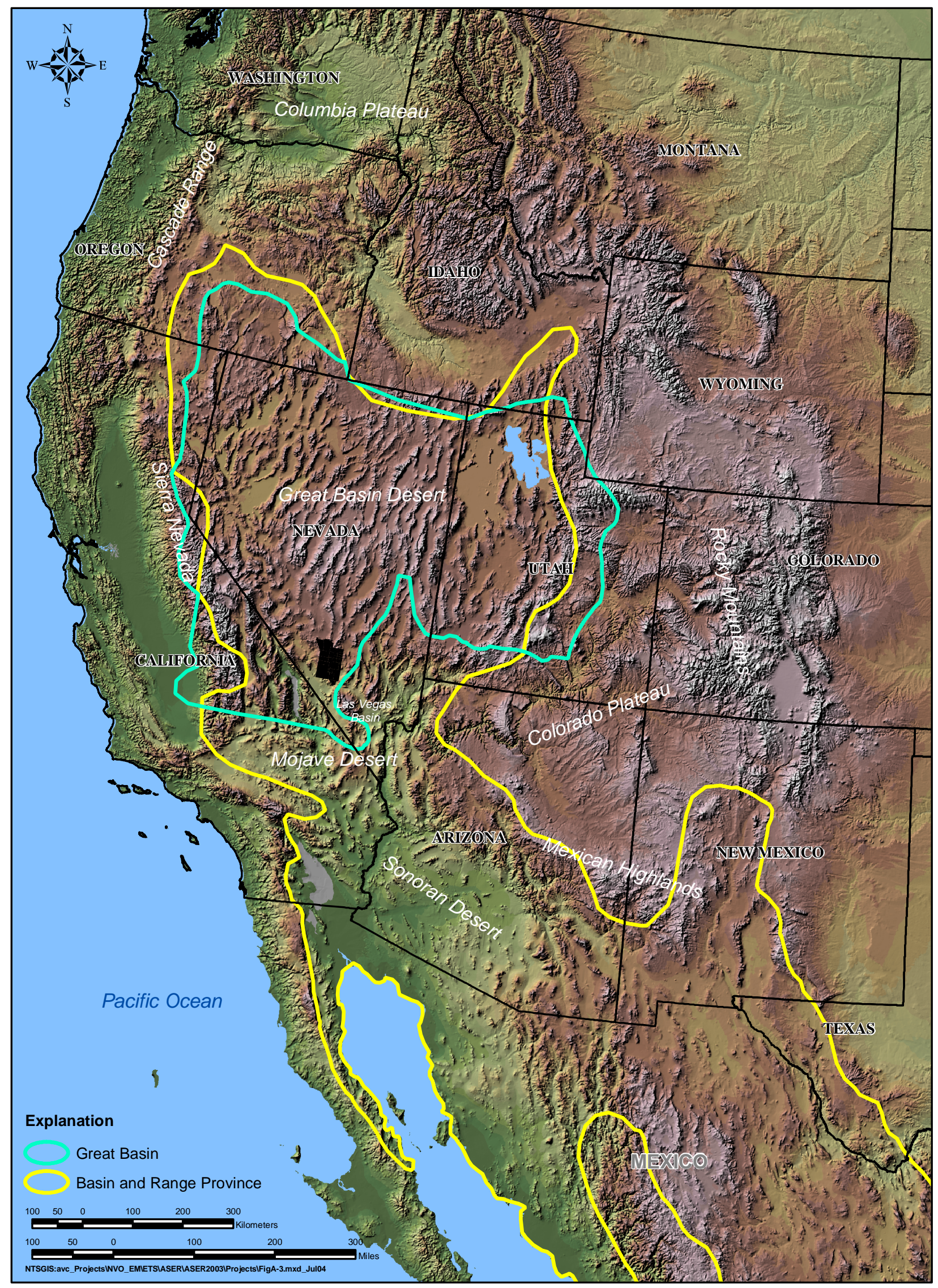

Figure 1-3

Color Relief Map Showing Locations of the Basin and Range Physiographic and Great Basin Hydrographic Provinces 


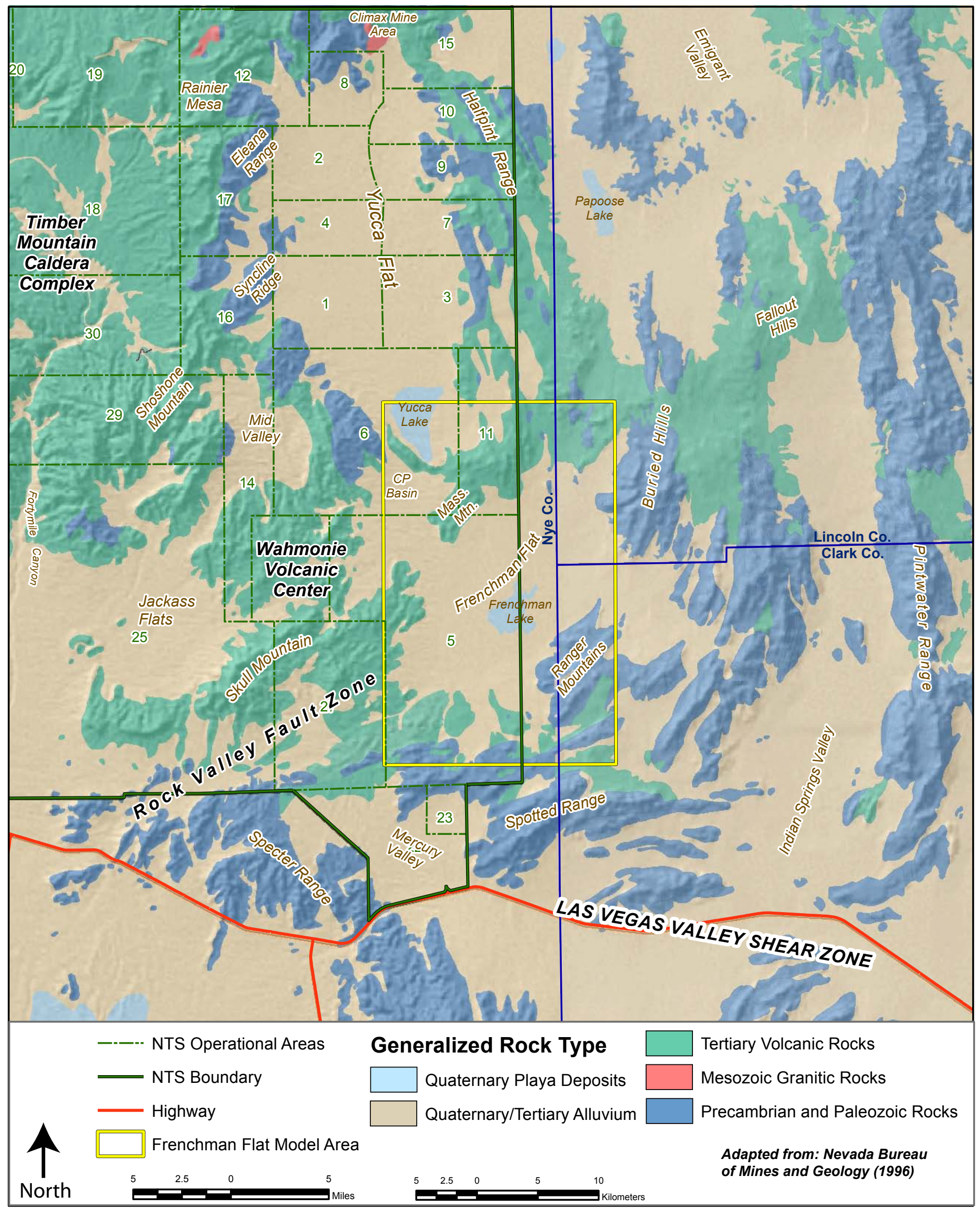

Figure 1-4 Generalized Geologic Map of the Frenchman Flat Region 


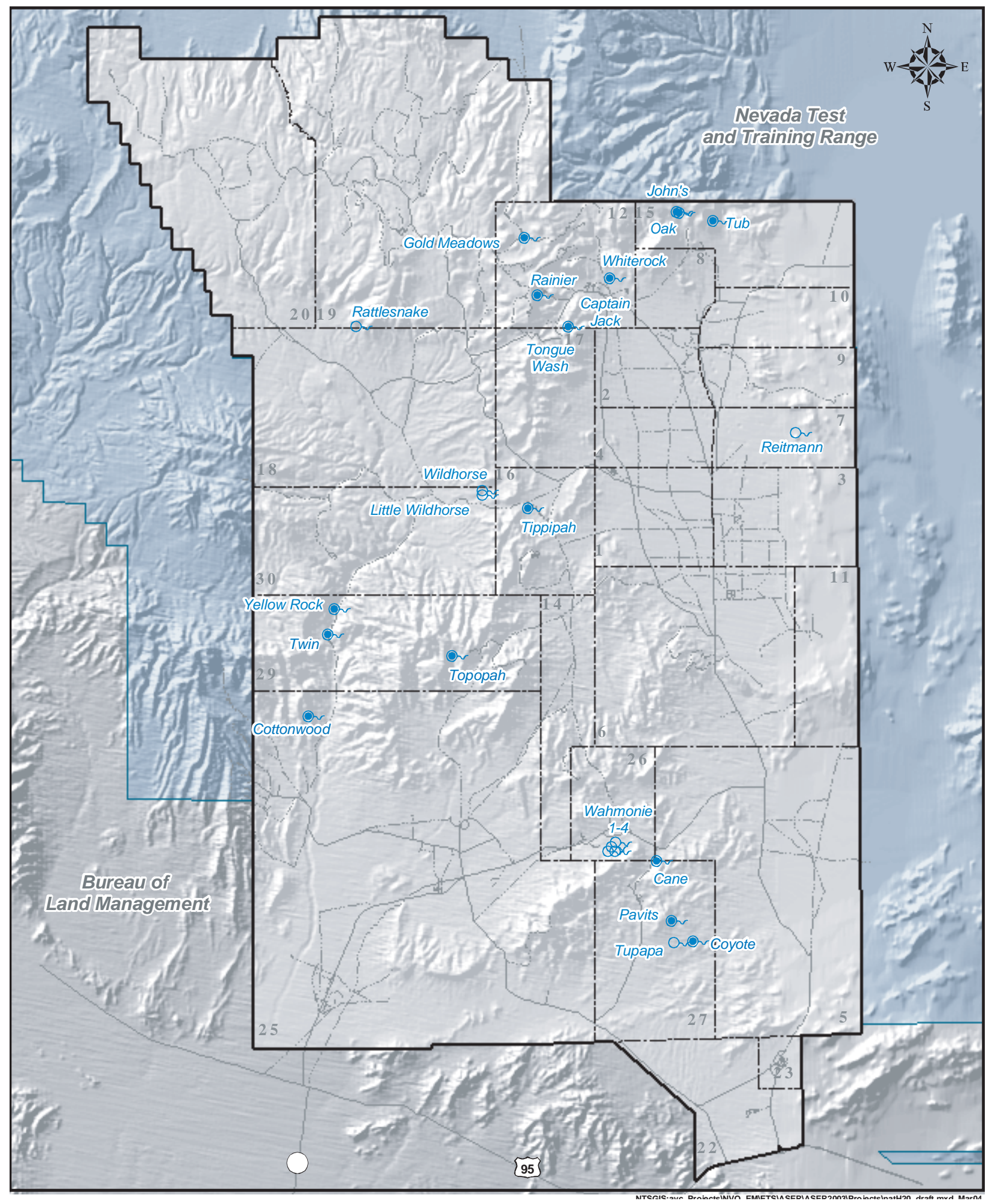

Figure 1-5

Natural Springs and Seeps on the Nevada Test Site

(After Hansen et al., 1997) 


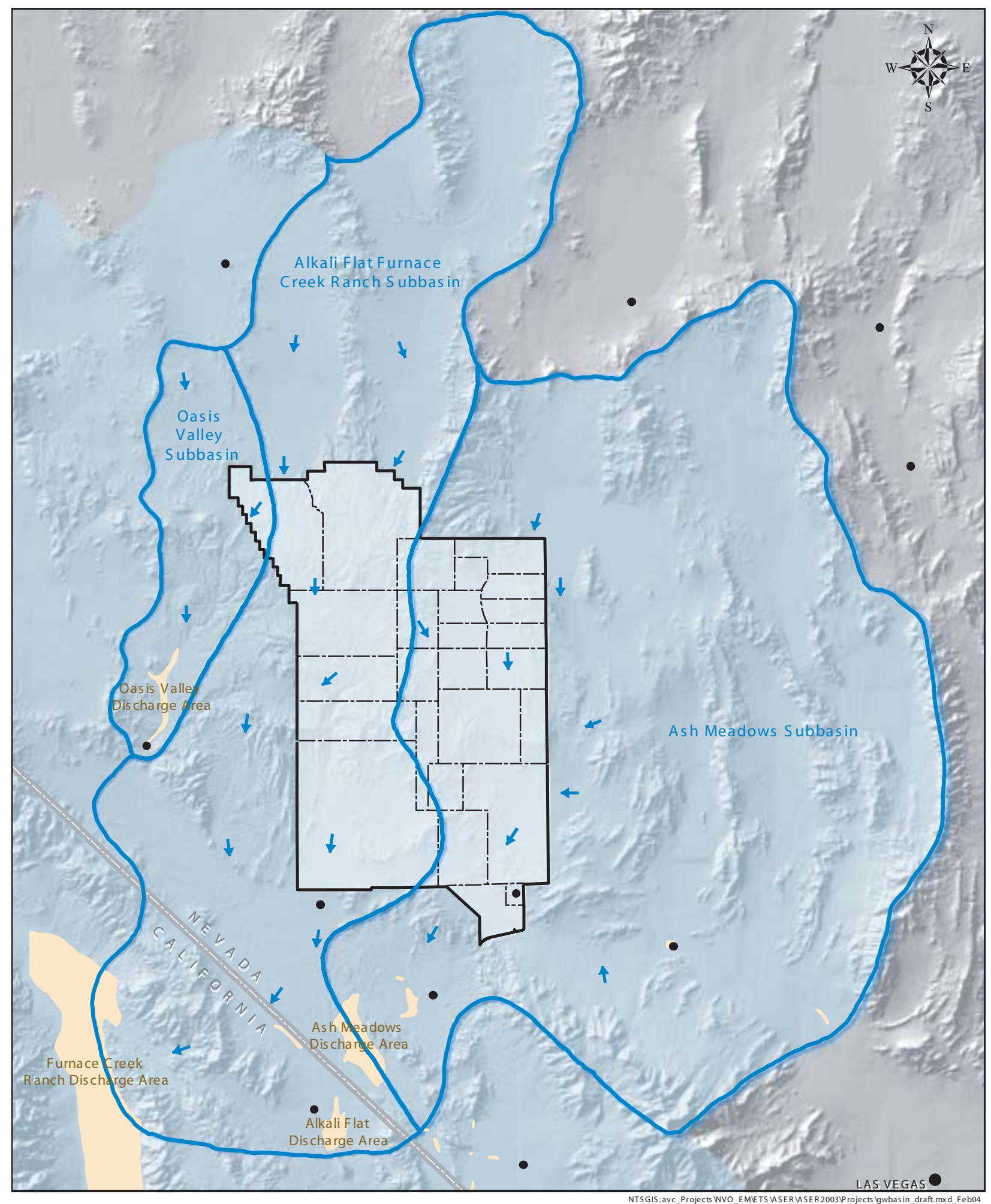

Figure 1-6

Groundwater Subbasins of the Nevada Test Site and Vicinity (Modified from Waddell et al., 1984 and Laczniak et al., 1996) Arrows show general direction of inferred groundwater flow. Black dots represent populated areas. 


\subsection{METHODOLOGY}

This section describes the process, methods, and data utilized to construct the Frenchman Flat hydrostratigraphic framework model. Because much of the initial model-building work was accomplished during Phase I (IT, 1998), some activities performed during Phase I are also included in this section.

\subsection{Model Construction Process}

A summary of the general work flow for model construction is provided below. The summary lists in general chronological order individual tasks accomplished to build the final framework model. More in-depth discussions of some of the major portions of the model-building process are provided in following subsections.

\section{Phase I (Fiscal Year [FY] 1997 and FY 1998)}

- Establish and define the boundaries of the model area.

- Assemble stratigraphic, lithologic, and alteration data for all drill holes within the model area.

- Assemble other existing geologic data and interpretive products, including geologic maps, cross sections, and geophysical investigations:

» Relevant hydrostratigraphic cross sections originally prepared during the UGTA Phase I regional modeling effort.

» Special-purpose maps, cross sections, and other data originally prepared in support of the DOE weapons testing program (WTP).

- Build upon existing databases to create an expanded stratigraphic drill hole database for the Frenchman Flat model.

- Develop a hydrostratigraphic classification system and HSU drill hole database for the Frenchman Flat model using stratigraphic, lithologic, and alteration data.

- Integrate the USGS structural model.

- Construct interpretive geologic cross sections, pseudo drill holes (i.e., control points), and structure-contour maps for selected HSUs.

- Input data and interpretive products into Environmental Resources Management Applications System ${ }^{\circledR}\left(\right.$ ERMA $\left.^{\circledR}\right)$ modeling software. 
- Resolve relational problems and modify the hydrostratigraphic framework model as necessary.

- $\quad$ Subject draft model to an internal review process.

- $\quad$ Revise draft model.

- Document the data used, their sources, interpretative approach, methods, etc.

- Submit hydrostratigraphic framework model and documentation to the UGTA hydrologic modelers.

- Submit model and documentation for internal and external reviews.

Phase II: Data Acquisition (FY 2001 and FY 2002)

- Drill five new wells.

- $\quad$ Conduct a 3-D seismic survey.

- Revise geophysical analyses (gravity and aeromagnetic data).

Phase II: Data Assessment and Model Building (this report, FY 2004 and FY 2005)

- Convert the 1998 ERMA $^{\circledR}$ model to the EarthVision ${ }^{\circledR}$ modeling platform.

- $\quad$ Revise model area boundaries.

- Conduct pre-emptive review.

- Compile data.

» Re-evaluate all existing data.

» Integrate new data.

- Develop new conceptual structural model.

- Enhance the existing Phase I hydrostratigraphic classification system (i.e., subdivide the alluvial and volcanic aquifer units) and revise HSU drillhole database.

- Input data into EarthVision ${ }^{\circledR}$ and build revised framework model.

- $\quad$ Resolve relational problems and modify the framework model as necessary.

- $\quad$ Subject draft base model to an internal review process.

- Revise draft base model. 
- Develop alternative scenarios.

- Subject alternative models to internal review process.

- Revise alternative models.

- Compile documentation package.

- Submit model to hydrologic modelers.

\subsection{Determination of Model Area Boundaries}

The Frenchman Flat model area is a north-south oriented, 19.1- by 30.0-km (11.9- by 19.1-mi) rectangular area encompassing more than $570 \mathrm{~km}^{2}\left(220 \mathrm{mi}^{2}\right)$. Vertically, the model extends from the ground surface to $5 \mathrm{~km}$ (3.1 mi) below mean sea level (Figure 2-1). The base of the model is below the top of the Precambrian sedimentary rocks that underlie the regional aquifer. This deep confining unit is considered to be the hydrologic basement ("LCCU" in Figure 2-1). Geographic coordinates that define the boundaries for the Phase II Frenchman Flat model area are given in Table 1-1.

The model area boundaries were constrained by the needs of the hydrologic modelers and by the limitations and benefits of using computer modeling software. The model area had to be large enough to encompass all potential regulatory boundaries and any subsequent or derivative flow and transport models. However, the area covered by the Frenchman Flat 3-D hydrostratigraphic framework model may not necessarily be the same as that covered in the final flow and transport model. The hydrostratigraphic framework model area encompasses all of the underground testing areas (i.e., radiological source areas) in northern and central Frenchman Flat. The model includes all relevant geologic features, including known and inferred geologic structures. It also encompasses plausible flow paths from the source areas, based on the initial Frenchman Flat model (IT, 1998), on the regional flow models (IT, 1999c), and on known hydrologic features (e.g., a possible flow path to Paleozoic-age rocks along the eastern portion of the model, or along the Rock Valley fault system in the southwest). The original northern boundary of the Phase I Frenchman Flat model, which coincided with the southern boundary of the Yucca Flat model area, was moved northward $4.37 \mathrm{~km}$ (2.7 mi) for the Phase II model. This creates an overlap with the southern portion of the Yucca Flat model area, and provides a larger hydrologic buffer on the north side of the Frenchman Flat model (Figure 1-1).

The model area had to be of a size that does not overload computing capabilities. Both software and hardware limitations, and desired level of detail in the model were considered. For ease of manipulation, the model area was kept rectangular in shape, which resulted in the inclusion of 
CP Basin in the northwest corner of the Phase II model. The CP Basin, located northwest of the Cane Spring fault, was not included in the Phase I model.

\subsection{Data, Interpretive Products, and Other Information Used in Model Construction}

Despite the presence of clusters of drill holes in portions of the model area (Drellack, 1997; Wagoner and Richardson, 1986) subsurface information in portions of the model area is sparse, particularly at deeper stratigraphic levels. However, geoscientists have been working in the NTS region for more than 40 years (Byers et al., 1989), and many sources of geologic and geophysical information and data relevant to the Frenchman Flat area are available. For example, most of the geologic units in the model are exposed at the surface within the NTS region, allowing direct observation of rock properties and characteristics. Drill hole and surface geophysical data are also available for these units. Other data for the adjacent Yucca Flat CAU area were also available (Gonzales et al., 1998), as well as published maps and geologic reports, and unpublished geologic and geophysical data originally collected in support of other NTS programs (e.g., WTP, Yucca Mountain Project [YMP], and Area 5 Radioactive Waste Management Site [RWMS]). Data also became available from five new boreholes and several new geophysical studies conducted in the study area. Ground surface elevations were imported from a digital elevation model (DEM) data set (IT, 1999a). This newer DEM was compiled from the most recent USGS 71/2-minute quadrangle maps. Surface and near-surface geologic information was derived from USGS geologic maps of the area.

Some of the more important sources of data and information used to construct the model are listed below and discussed in more detail in following subsections.

- Six USGS geologic quadrangle maps (Table 2-1)

- Lincoln County geologic map (Tschanz and Pampeyen, 1970)

- Gravity and magnetic investigations (Carr et al., 1975; Healey et al., 1987; Hudson, 1992 and 1997; Ponce et al., 1988; Wahl, 1995; Phelps and Graham, 2002; Phelps et al., 2005)

- Frenchman Flat alluvium study (Pawloski, 1996)

- Area 5 (RWMS) studies (Blout et al., 1995; Case, et al., 1984; RSN, 1994; REECo, 1993a, 1993b; BN, 2005; Shott et al., 1995, 1998; Snyder et al., 1994, 1995; Sully et al., 1993)

- A reconnaissance study of the Tertiary sediments in the Frenchman Flat area (Prothro and Drellack, 1997)

- USGS DEM data (IT, 1999a) were used as the basis for the final digital model. The original 90-m grid data were resampled to a 250-m grid for use in this model.

- Drill hole data (Drellack, 1997) 
- Well Cluster ER-5-3 (DOE, 2005a)

- Well Cluster ER-5-4 (DOE, 2005b)

- Seismic surveys (National Geophysical Company, Inc., 1966; Pullammanappallil and Louie, 1994; Prothro, 2002)

- Alluvium mineralogy study (Warren et al., 2002; Zavarin et al., 2002 and 2004)

\subsubsection{Other Models}

Several organizations have produced, or are in the process of producing, geologic and hydrologic models of various sizes and degrees of complexity for areas that adjoin or include portions of the UGTA Frenchman Flat area. The UGTA models that served as a starting point for the Frenchman Flat model have already been mentioned: the UGTA Phase I Regional Model (IT, 1996a, 1996b, 1996c, 1996d) and the initial Frenchman Flat Phase I hydrostratigraphic framework model (IT, 1998). The initial work on the Phase I Yucca Flat model (Gonzales et al., 1998) provided information for the northern portion of the Frenchman Flat model which overlaps the southern end of the Yucca Flat model area. The Death Valley regional groundwater flow model (D’Agnese et al., 1997; Workman et al., 2002; Sweetkind et al., 2001; Faunt, 1998; Faunt et al., 1999) was developed by the USGS at the request of a multi-organizational consortium which includes the National Park Service, the Bureau of Land Management, the State of Nevada, and NNSA/NSO for the YMP. The developers of the Frenchman Flat 3-D hydrostratigraphic framework model benefitted from access to these other models, and incorporated data and working concepts from them as necessary.

\subsubsection{Existing Geological and Geophysical Maps}

USGS geologists have been mapping in the NTS area since the 1950s, and have produced numerous geologic quadrangle maps at a scale of 1:24,000. Table 2-1 lists the six USGS geologic quadrangle maps that include portions of the Frenchman Flat model area. Data from other surface geologic maps at larger scales were also utilized (Table 2-2). Table 2-3 lists some of the special-purpose geological and geophysical maps that were studied and referred to during model construction. 
Table 2-1

Geologic Quadrangle Maps (Scale 1:24,000) Used in Construction of the Frenchman Flat Hydrostratigraphic Framework Model

\begin{tabular}{||l|l||}
\hline \multicolumn{1}{|c|}{ Quadrangle Name } & \multicolumn{1}{c|}{ Reference } \\
\hline \hline Mercury & Barnes et al., 1982 \\
\hline Camp Desert Rock & Hinrichs, 1968 \\
\hline Plutonium Valley & Hinrichs and McKay, 1965 \\
\hline Yucca Lake & McKeown et al., 1976 \\
\hline Frenchman Flat & Poole, 1965 \\
\hline Cane Spring & Poole et al., 1965 \\
\hline \hline
\end{tabular}

Table 2-2

Special Purpose Geologic Maps Used in Construction of the Frenchman Flat Hydrostratigraphic Framework Model

\begin{tabular}{||l|l||}
\hline \multicolumn{1}{|c||}{ Map Title and Scale } & \multicolumn{1}{c||}{ Reference } \\
\hline \hline $\begin{array}{l}\text { Digital Geologic Map of the Nevada Test Site and Vicinity, Nye, } \\
\text { Lincoln, and Clark Counties, Nevada, and Inyo County, California } \\
(1: 120,000)\end{array}$ & Slate et al., 1999 \\
\hline County Digital Geologic Maps (1:250,000) & $\begin{array}{l}\text { Nevada Bureau of Mines and } \\
\text { Geology, 1996 }\end{array}$ \\
\hline Geologic Map of Nevada (1:500,000) & Stewart and Carlson, 1978 \\
\hline $\begin{array}{l}\text { Geologic Map of the Death Valley Groundwater Basin and } \\
\text { Surrounding areas, Nevada and California (1:250,000) }\end{array}$ & Workman et al., 2002 \\
\hline
\end{tabular}




\section{Table 2-3}

Miscellaneous Special Purpose Maps Used in Construction of the Frenchman Flat Hydrostratigraphic Framework Model

\begin{tabular}{||l|l||}
\hline \multicolumn{1}{|c|}{ Map Title and Scale } & \multicolumn{1}{|c||}{ Reference } \\
\hline \hline $\begin{array}{l}\text { Geologic Surface Effects of Underground Nuclear Testing, Buckboard } \\
\text { Mesa, Climax Stock, Dome Mountain, Frenchman Flat, Rainier/Aqueduct } \\
\text { Mesa, and Shoshone Mountain, NTS, Nevada }\end{array}$ & Grasso, 2003 \\
\hline $\begin{array}{l}\text { Lineaments Identified in Northern Frenchman Flat, Nye, Lincoln, and } \\
\text { Clark Counties, Nevada (1:24,000) }\end{array}$ & Miller et al., 1993 \\
\hline $\begin{array}{l}\text { Preliminary Aeromagnetic Map of the Nevada Test Site and Vicinity, } \\
\text { Nevada (1:100,000) }\end{array}$ & Kirchoff-Stein et al., 1989 \\
\hline $\begin{array}{l}\text { Digital Aeromagnetic Map of the Nevada Test Site Area, Nye, Lincoln, } \\
\text { and Clark Counties, Nevada, and Inyo County, California (1:100,000) }\end{array}$ & Ponce, 1999 \\
\hline $\begin{array}{l}\text { Complete Bouguer Gravity Map of the Nevada Test Site and Vicinity, } \\
\text { Nevada (1:100,000) }\end{array}$ & Healey et al., 1987 \\
\hline $\begin{array}{l}\text { Isostatic Gravity Map of the Nevada Test Site and Vicinity, Nevada } \\
(1: 100,000)\end{array}$ & Ponce et al., 1988 \\
\hline $\begin{array}{l}\text { Digital Isostatic Gravity Map of the Nevada Test Site Area, Nye, Lincoln, } \\
\text { and Clark Counties, Nevada, and Inyo County, California (1:100,000) }\end{array}$ & Ponce et al., 1999 \\
\hline $\begin{array}{l}\text { Maps of the Thickness of Cenozoic Deposits and the Isostatic Residual } \\
\text { Gravity over Basement for Nevada (1:1,000,000) }\end{array}$ & Jachens and Moring, 1990 \\
\hline \hline
\end{tabular}

\subsubsection{Drill Hole Data}

Nearly 80 holes have been drilled in the Frenchman Flat area for various purposes, including construction of water wells and monitoring wells, emplacement holes for underground nuclear tests, and exploratory holes (RSN, 1990; Drellack, 1997). Most of these holes were drilled for the DOE in support of NTS programs, and data from most of these were held primarily in NTS agency files. During development of the UGTA Phase I regional model (IT, 1996a, 1996b, 1996c, 1996d) and the initial Phase I Frenchman Flat model (IT, 1998), most of these data were compiled, analyzed, and organized into databases for import into modeling software applications. Holes providing input for the Frenchman Flat framework model are listed in Appendix A and shown on Plate 2. The holes provide information on the geologic and hydrologic character and distribution of subsurface units. However, approximately half the holes listed in Appendix A are shallow alluvium holes and thus provide limited information. The principal holes that provide the most useful information are shown in Figure 2-2 and on Plate 1. 
Although much of the geologic information provided in Appendix A is typically referred to as data, it should be remembered that such information is a result of a rigorous interpretive process based on an integrated analysis of drill cuttings, rock core, geophysical logs, and surrounding surface exposures. Results from laboratory analyses such as petrography, $\mathrm{x}$-ray diffraction, and $\mathrm{x}$-ray fluorescence were also integrated into the stratigraphic interpretation when available.

\subsubsection{Phase II Well Drilling Initiative}

Five new wells were drilled and completed as part of the Phase II data acquisition initiative for the Frenchman Flat CAU, and provide important information and constraints for the framework model. The wells were intended to provide confirmatory information for the Frenchman Flat hydrogeologic model, and new detailed information about the geology, hydrogeology, and water chemistry in the immediate vicinity of the two underground nuclear testing areas within Frenchman Flat. Well Cluster ER-5-3 is located near the northern group of underground tests in Frenchman Flat, and Well Cluster ER-5-4 is located near the southern group of underground tests in central Frenchman Flat. The purpose and expectations of this drilling initiative are spelled out in the Frenchman Flat Hydrogeologic Investigation Wells Drilling and Completion Criteria and its addendum (IT, 2000, 2001). Data from these wells, combined with the 3-D seismic data, were important in the development of the modified structural model for Frenchman Flat. Information about the well clusters is summarized in the two subsections below.

\subsubsection{Well Cluster ER-5-3}

Well Cluster ER-5-3 is located in Frenchman Flat near the northern Frenchman Flat underground nuclear test area (Figure 2-2). The well cluster consists of three boreholes drilled on the same drill pad. The wells were drilled as part of the hydrogeologic investigation well program of Phase II Data Acquisition for Frenchman Flat. The primary purpose of constructing Well Cluster ER-5-3 was to obtain information to help characterize the hydrogeology near a group of underground nuclear test locations in this part of Frenchman Flat. Material for this discussion was abstracted from Completion Report for Well Cluster ER-5-3 (DOE, 2005a).

Three boreholes were drilled at this site in the attempt to penetrate saturated alluvium, the volcanic aquifer, and the tuff confining unit, and to reach total depth (TD) in the lower carbonate aquifer. Because of borehole instability problems the first borehole, Well ER-5-3, was terminated in the tuff confining unit before reaching the planned depth of 1,158.2 $\mathrm{m}(3,800 \mathrm{ft})$. Well ER-5-3\#2, was then drilled to the depth of 1,732.2 m (5,683 ft) and reached TD within the

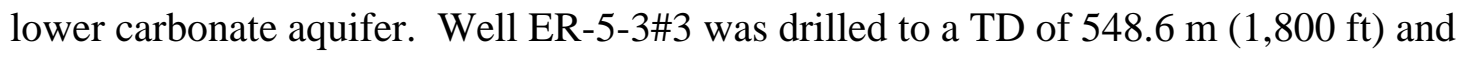
completed in the saturated alluvium. 
The unconfined water level, which is within the alluvial section at Well Cluster ER-5-3, is approximately $282.5 \mathrm{~m}$ (927 ft) below ground surface. Based on this preliminary fluid depth and the as-built surface elevation of 1,016.3 $\mathrm{m}$ (3,334.3 ft), the fluid level elevation at Well Cluster ER-5-3 is $733.8 \mathrm{~m}$ (2,407.3 ft). The potentiometric water level for Well ER-5-3\#2 (completed within Paleozoic-age carbonate rocks) is at a depth of $289.9 \mathrm{~m}$ (951 ft) below the ground surface. See also IT (2002) and SNJV (2004) for additional information on hydrologic studies made at this well cluster. No radionuclides above background levels were encountered during drilling of Well Cluster ER-5-3 (DOE, 2005a).

The wells penetrated Quaternary/Tertiary alluvium to the depth of $622.4 \mathrm{~m}(2,042 \mathrm{ft})$, with a 8.5-m (28-ft) thick basalt flow encountered within the alluvium. Tertiary-age tuffs were penetrated to the depth of approximately 1,425.9 m (4,678 ft), where the top of Paleozoic rocks was tagged in Well ER-5-3\#2. Geologic data from the well suggest that the contact between the Tertiary-age Bullfrog Tuff and Paleozoic-age dolomite is a fault, which is consistent with interpretation of 3-D seismic data in the area that shows a west-dipping normal fault cutting Well ER-5-3\#2 very near the 1,425.9-m (4,678-ft) depth. The depth to the top of Paleozoic rocks is $329 \mathrm{~m}$ (1,078 ft) deeper than predicted by the Phase I model. See Appendix B-1 for a graphical representation of the geology and hydrogeology of Well ER-5-3\#2.

The welded ash-flow tuffs that occur in the upper portion of the volcanic section above $914.4 \mathrm{~m}$ (3,000 ft) form welded-tuff aquifers. Severe lost circulation and borehole instability experienced while drilling these welded tuff intervals suggest that they are highly fractured and thus would likely form substantial aquifers in the vicinity of the well cluster. The volcanic rocks below $914.4 \mathrm{~m}$ (3,000 ft) consist mostly of poorly welded zeolitic tuffs that form a 511.5-m (1,678-ft) thick tuff confining unit at the well cluster site. The dolomite encountered below the volcanic section, at 1,425.9 $\mathrm{m}(4,678 \mathrm{ft})$, is the top of the regional carbonate aquifer.

\subsubsection{Well Cluster ER-5-4}

Well Cluster ER-5-4 is located in central Area 5 of the NTS (Figure 2-2), approximately $1.6 \mathrm{~km}$ $(1.0 \mathrm{mi})$ northwest of the Frenchman Lake playa, and $5.7 \mathrm{~km}(3.6 \mathrm{~m})$ south of Well Cluster ER-5-3. Well Cluster ER-5-4 consists of 2 boreholes drilled $30.5 \mathrm{~m}$ (100 ft) apart on the same drill pad. The wells were drilled as part of the hydrogeologic investigation well program, Phase II Data Acquisition for Frenchman Flat. The primary purpose of constructing Well Cluster ER-5-4 was to obtain information to help characterize the hydrogeology near a group of underground nuclear test locations in central Frenchman Flat. Material for this discussion was abstracted from Completion Report for Well Cluster ER-5-4 (DOE, 2005b). 
Well ER-5-4, the first well of the cluster, was drilled to a depth of 1,137.5 m (3,732 ft) in 2001. The completion design of the well allows for access to the alluvial aquifer at three depths. Well ER-5-4\#2 was drilled in 2002 to a depth of 2,133.6 m (7,000 ft). The well was completed in zeolitized, non-welded tuff (tuff confining unit) with a slotted interval at 1,976.9 to 2,029.3 m $(6,486.0$ to $6,657.7 \mathrm{ft})$.

The geologic units encountered at Well Cluster ER-5-4, in descending order, are 1,120.4 m (3,676 ft) of Quaternary and Tertiary alluvium, $242.6 \mathrm{~m}$ (796 ft) of generally unaltered nonwelded and welded ash-flow tuff of Tertiary age, and $770.5 \mathrm{~m}$ (2,528 ft) of mostly zeolitic nonwelded tuff, also of Tertiary age. Data from an imaging log indicate bedding dips of about 30 degrees to the east-southeast, which is consistent with dips determined from the seismic data. The wells encountered thicker alluvium and volcanic rocks than expected, and the deeper well, Well ER-5-4\#2, at 2,133.6 m (7,000 ft), did not reach the older Tertiary sedimentary rocks or Paleozoic rocks as predicted. The pre-drill estimate for the depth to Paleozoic rocks ranged from 1,158 to $1,524 \mathrm{~m}$ (3,800 to $5,000 \mathrm{ft}$ ) depending on the exact position of the borehole relative to a large inferred buried fault in the Phase I model. See Appendix B-2 for a graphical representation of the geology and hydrogeology of Well ER-5-4\#2.

The water level in both wells is approximately $221.6 \mathrm{~m}$ (727 ft) below ground surface. No radionuclides above background were encountered in the groundwater produced from either well in the cluster (DOE, 2005b).

\subsubsection{Geophysical Data and Investigations}

Numerous geophysical investigations have been conducted in Frenchman Flat since the 1960s, including seismic, resistivity, magnetic, and gravity surveys. Most recently, in FY 2001 and 2002, the UGTA Phase II data acquisition initiative for Frenchman Flat included a high resolution 3-D seismic survey of the two Frenchman Flat testing areas (see Appendix D), and analysis of existing gravity data in Frenchman Flat using 3-D inversion methods (Phelps and Graham, 2002). Also, a magnetotelluric (MT) survey was conducted in the Yucca Flat vicinity in 2003 as part of the Phase I data acquisition initiative for Yucca Flat. The two southern-most MT transects included measurements within the Frenchman Flat model area. The USGS collected additional gravity data in FY 2003 in the northwestern portion of the model area, including CP Basin and Massachusetts Mountain (Phelps et al., 2005).

Data and interpretations for all the geophysical investigations conducted in Frenchman Flat were reviewed during model construction and, where appropriate, integrated into the hydrostratigraphic framework model. Information from geophysical investigations was 
integrated with surface geology and drill hole data to develop a structural model of the basin and determine the distribution of HSUs. The geophysical data were also utilized during development of alternative scenarios. Each of the geophysical methods conducted in Frenchman Flat and used during model construction is discussed below.

\subsubsection{Gravity Data}

Gravity methods have been used in the Frenchman Flat vicinity since the 1960s to define the overall shape of the basin, determine approximate locations of major faults, and estimate the depth to pre-Cenozoic rocks (Poole, 1965; Healey, 1965; Carr et al., 1975; Miller and Healey, 1986; Grauch and Hudson, 1995; Wahl, 1995; Phelps and Graham, 2002; Phelps et al., 2005). The data indicate that Frenchman Flat is a northeast-oriented oval-shaped basin narrower at its southwest end. Strong gravity gradients are observed around the margins of the basin, particularly along the southeast and northeast margins, suggesting large basin-forming faults in these areas (Carr et al., 1975; Grauch and Hudson, 1995; Phelps and Graham 2002). Estimates of the maximum depth to pre-Cenozoic rocks range from 1,219.2 to 1,676.4 m (4,000 to 5,500 ft) in the earlier investigations (Poole, 1965; Carr et al., 1975; Miller and Healey, 1986; Wahl, 1995).

Phelps and Graham (2002) used an iterative gravity inversion method with a density model of the Cenozoic rocks that varies with depth (based on density data from Well Clusters ER-5-3 and ER-5-4), to estimate the maximum depth of the basin (i.e., depth to pre-Cenozoic rocks) at $2,400 \mathrm{~m}(7,874 \mathrm{ft})$. This estimate is consistent with recently acquired data from deep drilling at Well ER-5-4\#2 and from the 3-D seismic reflection survey (see Section 2.3.5.4). Phelps and Graham (2002) used data from 3,746 gravity measurements in and around Frenchman Flat, including 642 made in the basin itself and 233 made on surrounding pre-Cenozoic outcrops. Phelps and Graham (2002) verified the general shape of the basin as determined in the earlier investigations, and found no indication that major horst and graben structures are present beneath the basin (Figure 2-3). However, a northwest-trending, down-to-the-southwest gradient appears to separate the deeper basin occupying the southwestern two thirds of Frenchman Flat from a structural platform beneath the northeast portion of the basin. This feature is also quite evident in the maximum horizontal gradient map (Grauch and Hudson, 1995) and in the 3-D seismic data.

High-spatial-frequency gravity measurements were made in Frenchman Flat in 2001 as part of the 3-D seismic reflection survey effort. A total of 2,991 measurements were made within a $22.5-\mathrm{km}^{2}\left(14-\mathrm{mi}^{2}\right)$ area covering northern and central Frenchman Flat to provide near-surface, gravity-derived, static corrections to the seismic data. A Bouguer gravity map constructed from 
this data set indicated that the data are consistent with gravity data from previous investigations (Healey et al., 1987).

Additional gravity measurements were made in 2003 by the USGS in the northwest portion of the model area, including CP Basin and Massachusetts Mountain (Phelps et al., 2005). These data indicated that CP Basin is deepest on its eastern side, adjacent to the Cane Spring Fault. However, the gravity data did not indicate substantial vertical offset along the fault. These new data also indicated that the substantial negative gravity anomaly at Massachusetts Mountain (an area with few controlling data points ([Wahl, 1995; Phelps and Graham, 2002]), was not as pronounced when the new data points from this survey were taken into consideration.

The various gravity investigations conducted in and around Frenchman Flat provided valuable information during construction of the Frenchman Flat hydrostratigraphic model. The overall shape of the basin observed in the gravity data was honored in developing a structural model for Frenchman Flat. Areas with strong gravity gradients provided information on the approximate locations of major basin-forming faults. Gravity data also provided information for estimating the depth to pre-Cenozoic rocks in areas of little or no subsurface control. Figure 2-4 shows the locations of gravity measurements in the Frenchman Flat vicinity.

\subsubsection{Ground Magnetic Data}

Ground magnetic surveys were conducted as part of a special geologic and geophysical study of northern Frenchman Flat (Carr et al., 1975). These data were collected along 11 transects (Figure 2-4) and used by Carr et al. (1975) to determine the edges of several basalt lava flows intercalated within the alluvium in northern Frenchman Flat. Basalt was encountered in drill holes UE-5i and UE-5k (Dixon et al., 1967; Byers and Miller, 1966), and subsequently in UGTA Well Cluster ER-5-3 (DOE, 2005a). These data were utilized to establish the extent and thickness of buried basalt flow aquifers within the Frenchman Flat hydrostratigraphic framework model.

\subsubsection{Aeromagnetic Data}

Numerous aeromagnetic surveys have been flown over the Frenchman Flat vicinity (Carr et al., 1975; Grauch and Hudson, 1995; McCafferty and Grauch, 1997; Phelps et al., 2005). Carr et al. (1975) used aeromagnetic data to identify and evaluate the subsurface extent of magnetic anomalies caused by basalt flows and the presence of Rainier Mesa Tuff beneath the northern portion of Frenchman Flat. 
Grauch and Hudson (1995) used aeromagnetic data to evaluate the distributions of volcanic rocks beneath the basin and identify buried faults. Several north-trending linear magnetic boundaries were observed beneath Frenchman Flat that Grauch and Hudson (1995) interpreted to be buried, down-to-the-west normal faults. This interpretation of the aeromagnetic data formed an important component of the structural model of the original Frenchman Flat Phase I hydrostratigraphic framework model. However, these faults are not observed in the gravity data or 3-D seismic data, and thus likely result from other geological or geophysical effects. The current Phase II model does not include these aeromagnetic-inferred faults.

The USGS collected additional aeromagnetic data in the northwestern portion of the model area in 2003 (Phelps et al., 2005). This area includes CP Basin, the southern end of Yucca Flat, and the extreme northwest portion of Frenchman Flat.

Aeromagnetic data were the least useful of all the geophysical data utilized in the Frenchman Flat area. This is due mostly to the great thickness of alluvium within the basin and the presence of both positively and negatively magnetized units within the volcanic rocks of the area.

\subsubsection{Natural Source Magnetotelluric Survey}

In the fall of 2003, the USGS conducted a natural-source MT survey in the Yucca Flat vicinity to better characterize pre-Tertiary stratigraphy and structure beneath Yucca Flat. Fifty-two MT recording stations were arranged along six generally west-to-east profiles extending across Yucca Flat (Figure 2-5). The two southern-most MT profiles extend into the Frenchman Flat model area, and information from these profiles was incorporated into the Frenchman Flat model. The southern-most transect stretches from Mid Valley on the west, crosses CP Basin, and ends just north of Massachusetts Mountain. The other transect extends from west to east across Yucca Lake in extreme southern Yucca Flat.

BN geologists analyzed the MT data sets and found that MT stations across CP Basin delineate the Cane Spring fault and indicate that the fault forms the eastern boundary of the basin. MT data show that rocks east of the fault consist of a relatively thin section of Tertiary volcanic rocks overlying structurally high pre-Tertiary carbonate. Rocks west of the fault consist of thicker alluvium and volcanic rocks directly overlying a thick section of low resistivity rocks that are interpreted to represent Mississippian siliciclastic rocks. The siliciclastic rocks appear to be confined in extent to the eastern portion of CP Basin adjacent to the Cane Spring fault. However, a relatively thin (e.g. 100-m [330-ft]) section of Mississippian siliciclastic rocks could be present beneath the western portion of the basin. Such a section would be too thin to be resolved by the MT method. 
Data from the survey lines that cross the Yucca Flat playa indicate that the alluvium around the playa is much less resistive than alluvium in other parts of Yucca Flat, as expected for finegrained playa deposits. High resistivity values to a depth of 3,000 m (9,842 ft) beneath southern Yucca Flat indicate that pre-Tertiary rocks beneath the southern portion of the basin probably consist mostly of carbonate.

\subsubsection{Controlled-Source Audio-Frequency Magnetotelluric Survey}

A vector controlled-source audio-frequency magnetotelluric (CSMAT) survey was conducted in Frenchman Flat in 1990 to help characterize the subsurface geology in the vicinity of the Area 5 RWMS (Zonge, 1990). Two lines of vector CSMAT data were gathered in the northern portion of Frenchman Flat using two transmitter sites located in the southern portion of the valley. Several single-receiver stations were located in the southern portion of Frenchman Flat (Figure 2-5).

The CSMAT data provided information on the depth to the water table and on the depth and character of the Paleozoic rocks beneath the northwestern portion of Frenchman Flat. The water table is clearly visible along the southern line and the eastern half of the northern line, and appears relatively flat in an east-west direction. The thickness of unsaturated alluvium is slightly greater along the northern line, which is consistent with the higher surface elevation in that area.

The top of a deep resistive layer that likely corresponds to the top of pre-Tertiary rocks is observed at approximately 1,000 $\mathrm{m}$ (3,280 ft) depth beneath the western portion of the northern line and at approximately 1,300 $\mathrm{m}(4,270 \mathrm{ft})$ depth beneath the eastern portion of the line. This deep resistor is not observed on the southern line, which indicates that the top of pre-Tertiary rocks is below the depth of investigation $(1,500 \mathrm{~m}[4,920 \mathrm{ft}])$. These observations are generally consistent with the depth to top of pre-Tertiary rocks as determined from other data such as gravity and seismic, and from Well ER-5-3\#2. Gravity and 3-D seismic data indicate the top of pre-Tertiary rocks at between 1,250 and 1,750 $\mathrm{m}(4,100$ to 5,740 ft) in the area, with pre-Tertiary rocks deepening to the south and east. Well ER-5-3\#2, located approximately $670 \mathrm{~m}(2,200 \mathrm{ft})$ north of the western portion of the northern line, encountered the top of pre-Tertiary dolomite at 1,425.9 m (4,678 ft). The relatively high resistivity (100 to 400 ohm-meters) of the deep resistive layer along the northern line indicates that it likely consists of carbonate rocks, which is consistent with data from Well ER-5-3\#2, and that the carbonate aquifer is present below the northwestern portion of the basin. 


\subsubsection{Other Resistivity Surveys}

Electrical resistivity surveys were conducted around the Frenchman Lake playa in 1962 in support of the Small Boy series of above-ground nuclear tests (Scott, 1962; Scott and Black, 1962). Information from these early resistivity surveys was utilized during model construction to help determine the thickness of the Frenchman Flat playa deposit and the depth to the LCA in the vicinity of the Frenchman Lake playa. Data from the resistivity surveys indicate that the depth to higher resistivity units such as welded volcanic rocks and Paleozoic sedimentary rocks

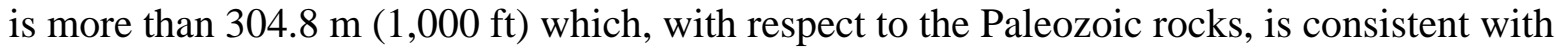
gravity data (Phelps et al., 2005). The data also indicate that the playa deposits are greater than $91.4 \mathrm{~m} \mathrm{(300} \mathrm{ft)} \mathrm{thick,} \mathrm{which} \mathrm{is} \mathrm{consistent} \mathrm{with} \mathrm{nearby} \mathrm{drill} \mathrm{hole} \mathrm{data.} \mathrm{Figure} \mathrm{2-5} \mathrm{shows} \mathrm{the}$ locations of these early resistivity measurements.

\subsubsection{Seismic Refraction Surveys}

Two programs of seismic refraction surveys have been conducted in Frenchman Flat. The first was conducted (in conjunction with the reflection survey described in Section 2.3.5.8) in 1966 in the northern portion of the basin (National Geophysical Company, Inc., 1966) to help characterize the subsurface geology of the area for underground nuclear testing. It consisted of 8 lines, each approximately 1,500 m (4,921 ft) long, and all oriented in a general east-west direction (Figure 2-6). The refraction data are of limited use due to the shallow depth of investigation of these relatively short lines. However, the data do seem to confirm the presence of a higher velocity alluvium at relatively shallow depths (213.3 to $243.8 \mathrm{~m}$ [700 to $800 \mathrm{ft}$ ]) beneath much of the northern portion of the basin.

Another seismic refraction survey was conducted in 1982, and consisted of 2 northwestsoutheast oriented lines that ran from CP Basin into the western portions of Frenchman Flat (Figure 2-6). These long lines provided useful structural information to a depth of $3 \mathrm{~km}$ $(9,842 \mathrm{ft})$. Interpretation of the seismic data indicates that the Cane Spring fault has a maximum throw of $500 \mathrm{~m}$ (1,600 ft) down to the northwest, and a minimum dip of 72 degrees to the northwest (Pullammanappilli and Louie, 1994). The data also indicate that a down-to-the-east fault is present along the western side of Frenchman Flat. In addition, the data show velocity horizons along the western side of Frenchman Flat, which likely correspond to geologic units, dip eastward into the basin.

\subsubsection{2-D Seismic Reflection Survey}

A 2-dimensional seismic reflection survey was conducted in the northern and central portions of Frenchman Flat in 1966 (in conjunction with the first refraction survey series described in Section 2.3.5.7). This reconnaissance survey consisted of six seismic reflection lines, five 
oriented east-west and one oriented generally north-south (Figure 2-6). Although the original seismic profiles could not be located for interpretation during construction of the Frenchman Flat hydrostratigraphic model, the model developers reviewed an informal report (National Geophysical Company, Inc., 1966) that summarizes the results of the survey. The report indicates that the survey was of limited success. The pre-Tertiary rocks were not imaged and there is no mention of any volcanic horizons being identified. Faults cutting the alluvial section were identified but could not be correlated between lines due to the large line spacing. Some of the east-west lines were said to indicate "steep” east dips along the western portions of the lines. This is consistent with later geophysical and geologic data that show rocks beneath the western portion of Frenchman Flat dipping east into the basin.

\subsubsection{3-D Seismic Reflection Survey}

A high resolution 3-D seismic reflection survey was conducted in Frenchman Flat in 2001. The purpose of the survey was to better constrain structural interpretations and distributions of hydrostratigraphic units beneath the underground nuclear testing areas in Frenchman Flat. The survey area covered $35.8 \mathrm{~km}^{2}\left(13.8 \mathrm{mi}^{2}\right)$ in the northern and central portions of Frenchman Flat (Figure 2-6). Approximately 4.5 million seismic traces were acquired within the survey area. These were stacked (i.e., grouped) into 153,855 traces within a 15.2-m by 15.2-m (50-ft by 50-ft) bin spacing (i.e., grid). Appendix D provides additional details regarding the acquisition parameters, processing, and interpretation of the Frenchman Flat 3-D seismic survey. The horizons and faults mapped from these data were converted from time to depth and integrated directly into the hydrostratigraphic framework model.

Results from the 3-D seismic survey provided valuable information on the structure and hydrostratigraphy beneath the northern and central portions of the basin. Three seismic horizons were mapped in detail. These included from shallowest to deepest: 1) the base of the alluvium, which corresponds hydrostratigraphically with the base of the alluvial aquifers and playa confining units; 2) the base of the welded volcanic rocks, which generally corresponds to the base of the volcanic aquifers and top of the volcanic confining units; and 3) the top of the Paleozoic rocks, which is interpreted to correspond to the top of the lower carbonate aquifer. In addition, two separate zones of poor seismic reflectivity in the alluvium were tentatively mapped, and are interpreted to represent older playa deposits (i.e., playa confining units) based on correlation of the seismic data with information from Well ER-5-4. Mapping of the seismic horizons, along with information from Well ER-5-4\#2, showed that welded volcanic rocks were more extensive beneath the basin than originally thought. It also provided much better constraints on the depth to the Paleozoic rocks, particularly in the northern portion of the basin where these rocks occur higher in the section. 
Important structural information was obtained from the seismic data. Of particular importance was the recognition of a previously unknown buried fault zone that strikes northwest beneath the northern portion of Frenchman Flat. This fault zone offsets the Paleozoic and volcanic rocks as much as $610 \mathrm{~m}(2,000 \mathrm{ft})$ along a series of down-to-the-southwest faults.

\subsubsection{Alluvium Studies}

Alluvial deposits that fill Frenchman Flat are particularly important in the Frenchman Flat model. Nine of the ten underground nuclear tests conducted in Frenchman Flat were emplaced within the alluvium, and initial modeling during Phase I showed that radionuclides from these tests did not migrate out of the alluvium during the 1,000-year transport simulations (IT, 1999c). In the Phase I Frenchman Flat hydrostratigraphic framework model, the alluvium was modeled as a single HSU. However, an early objective of the Phase II modeling effort was to subdivide the alluvium into multiple HSUs to allow for more realistic and versatile modeling of these important deposits. Information utilized for subdividing the alluvium came from various sources, including two alluvium investigations. Pawloski (1996) sought to define an apparent older, denser alluvium recognized in Frenchman Flat by early investigators. Warren et al. (2002) focused on characterizing the mineralogic and chemical nature of the alluvium in Frenchman Flat, primarily at Well ER-5-4. These two studies are described in more detail in the following subsections. Information from Well Clusters ER-5-3 and ER-5-4 (Sections 2.4.5.1 and 2.4.5.2) and geophysical data, including 3-D seismic (Section 2.4.7.9 and Appendix D) and surface magnetics (Section 2.4.7.2), also provided important information on the alluvium.

\subsubsection{Differentiation of the Older Alluvium}

Because of apparent variability of the alluvium in Frenchman Flat mentioned by earlier investigators (Carr et al., 1975 and Miller and Healey, 1986), Pawloski (1996) conducted an investigation of the alluvium in northern Frenchman Flat using existing literature, lithologic logs, and geophysical data to determine if the alluvial deposits could be subdivided on the basis of hydrogeologic characteristics. Pawloski (1996) focused on characterizing the nature and extent of an interval of dense alluvium recognized by Carr et al., (1975) and Miller and Healey (1986), that might possess hydrologic properties that are slightly different from the rest of the alluvial section. Although Pawloski (1996) confirmed that this subunit can be distinguished on the basis of bulk density, porosity, and velocity, it appeared to be discontinuous and of local extent, having been encountered in only a few holes in northern Frenchman Flat. Information from Pawloski (1996) was used during construction of the Phase II model to help designate and model a separate older alluvial aquifer beneath northern Frenchman Flat. 


\subsubsection{Reactive Secondary Mineral Study for Alluvium in North Central Frenchman Flat}

Hydrologic source term modeling has shown that radionuclide transport is highly sensitive to the abundance and availability of certain reactive minerals. Detailed chemical, mineralogic, and micrographic analyses were used to characterize the 1,137.5-m (3,732-ft) thick sequence of alluvium at Well ER-5-4 (Warren et al., 2002). Analysis methods for this study included x-ray diffraction (XRD), $x$-ray fluorescence (XRF), scanning electron microscope (SEM), quantitative petrography, and electron microprobe. The objective of the study was to provide detailed information regarding the distribution of reactive minerals in the thick alluvial section in northcentral Frenchman Flat. The task also supported a geostatistical characterization study by LLNL (Carle et al., 2002).

As summarized in Warren et al. (2002), important findings include:

- The alluvium within Well ER-5-4 can be subdivided into 12 lithologically, chemically, and/or mineralogically distinctive layers.

- The alluvial deposits have not been significantly altered since deposition.

- Though the layers in Well ER-5-4 are recognized within nearby holes UE-5n and RNM-1, they do not relate well to more distant parts of Frenchman Flat (e.g. Well ER-5-3).

- Detritus from the Wahmonie Formation is dominant at Well ER-5-4, indicating a source to the west.

- Minerals within the alluvium are partitioned among three components: crystals, lithic fragments, and matrix. Only those reactive minerals within the matrix are expected to interact with groundwater.

- Clays are present as coatings on crystals and lithic fragments, which limits their reactivity to groundwater.

- Authigenic iron and manganese oxides occur both as phenocrysts and in the matrix.

- Carbonate minerals (secondary calcite) are common in the matrix of the deeper layers.

- Zeolite minerals, on the other hand, occur mostly in lithic fragments and in shards, and consequently are largely unavailable for interaction with groundwater.

Warren et al. (2002) provided information used to subdivide the alluvium in the hydrostratigraphic framework model, and to characterize the nature and distribution of the older alluvial aquifer beneath northern Frenchman Flat. Mineralogic information from Well ER-5-3 
indicates that the tuffaceous matrix of the older alluvial deposits has been altered to zeolite. This may explain the physical differences between the older and younger alluvium observed by Pawloski (1996) and earlier investigators. The lack of zeolitic alteration within older alluvium in Well ER-5-4 provides a lateral constraint (i.e. southern limit) on the distribution of the older alluvial aquifer, and supports the conclusion of Pawloski (1996) that the older, denser alluvium in northern Frenchman Flat is limited in extent.

Detailed analytical results of lithologic samples from Well ER-5-4 reported in Warren et al. (2002) are consistent with lithologic descriptions from the well (DOE, 2005b) that describe a relatively thick interval of clay and silt within the coarser-grained alluvial section. Based on the lithology and correlation with seismic data, the interval 704.7 to $869.1 \mathrm{~m} \mathrm{(2,312} \mathrm{to} \mathrm{2,940} \mathrm{ft)} \mathrm{was}$ modeled separately and designated as an older playa confining unit.

\subsection{Pre-Emptive Review}

Before the Phase II Frenchman Flat hydrostratigraphic model was constructed, the UGTA TWG initiated a pre-emptive review process. The purpose of this review was to provide a forum for the TWG to evaluate the model and model-building process at various stages during construction of the Phase II model. The pre-emptive review subcommittee consisted of scientists from LANL, LLNL, SNJV, and the USGS. Pre-emptive reviews for the Frenchman Flat model were conducted on October 30, 2003, and March 3, 2004. Data sets, current status of the model, alternative interpretations, and the path forward were assessed from both technical and programmatic perspectives. Comments and suggestions from the subcommittee members were addressed as appropriate.

\subsection{Model Construction}

Prior to the actual digital construction of the 3-D framework model, two important tasks had to be completed. First, a structural model of the area had to be developed that included the locations and orientations of all the relevant faults in the model area. Fault information was imported into EarthVision ${ }^{\circledR}$, a 3-D computer modeling program, to form a fault-tree model that depicts all the model faults in 3-D space. The fault-tree model formed the framework on which the hydrostratigraphic model was built. A detailed discussion of the structural model is provided in Section 3.0 of this report.

Although the framework of the Frenchman Flat hydrostratigraphic model is the fault-tree, the foundation of the model is the hydrostratigraphic classification system. This system was developed through a rigorous analysis of stratigraphic and lithologic data in and around Frenchman Flat, and consists of 17 HSUs that form 3-D volumetric layers in the model. A 
detailed description of the hydrostratigraphic system developed for the Frenchman Flat model is provided in Section 4.0 of this report.

\subsubsection{Use of Computer Software to Construct the Model}

Computer software designed to handle large amounts of data and interpretive products is used to present the hydrostratigraphic framework for the use of the flow-and-transport modelers. The size of the study area, the large amount of data to be manipulated, and the complexity of the geologic setting of the NTS and vicinity demand sophisticated algorithms for production of realistic interpretations. As the field of computer modeling rapidly grows, new software becomes available which improves the efficiency and results of the modeling process. Thus, the UGTA hydrostratigraphic modeling efforts for Frenchman Flat were initiated in 1997 using ERMA $^{\circledR}$ software, but the data were migrated in 2002 to EarthVision ${ }^{\circledR}$, an improved system, for continuation of the modeling process. See IT (1998) and IT (1996a) for descriptions of modeling done with ERMA ${ }^{\circledR}$ software.

EarthVision ${ }^{\circledR}$ software (Version 7.5, by Dynamic Graphics) accepts spatially located data such as the elevation of the tops of stratigraphic units in boreholes, outcrop traces, locations and orientations of faults, and other data such as seismic profiles and geophysically derived surfaces. The software then applies geology-based geometric "rules" to determine the most likely 3-D interpretation of the geology in the model area that honors the input data. After the data and interpretive products are input, the computer's interpretation can be adjusted to suit the geologist's concept, to incorporate additional information, or to test alternate hypotheses. It is possible to easily and thoroughly evaluate a geologic model built in EarthVision ${ }^{\circledR}$ and examine relationships of the individual elements. Because the interpretive rules are geology-based, the model automatically satisfies many fundamental geometric requirements for geologic structure and, therefore, requires much less work to check and adjust than in the previously used modeling software (i.e., ERMA ${ }^{\circledR}$ ). EarthVision ${ }^{\circledR}$ can be used to produce maps and profiles to illustrate the structure and distribution of HSUs for any portion of the model.

The final hydrostratigraphic framework model will be provided in digital form to UGTA flowand-transport modelers who will use the framework model to model groundwater flow and contaminant movement within the Frenchman Flat study area. The plates, maps, profiles, and other figures included with this documentation report are intended to provide only general illustrations of the physical framework, structure, and distributions of the HSUs to aid the reader. The flow-and-transport modelers will receive the complete, digital, 3-D model (Figure 2-1). 


\subsubsection{Model Input}

As mentioned previously, the Phase I Frenchman Flat model (IT, 1998) was used as the initial starting point for the Phase II model. However, considerable re-building of the original model was required to incorporate new data acquired during Phase II data collection and to expand the hydrostratigraphic classification system to include more HSUs. A new fault-tree model was developed for the Phase II model based on a revised structural model of the basin resulting from interpretation of Phase II data, particularly from new drill holes and the 3-D seismic survey. Fault locations were digitized from maps and imported into EarthVision ${ }^{\circledR}$ along with information regarding fault dip and offset. Locations of faults determined from 3-D seismic data were imported directly into EarthVision ${ }^{\circledR}$.

Input regarding HSUs included a drill hole database consisting of elevation tops for HSUs (Appendix A), surface (i.e., outcrop) HSU maps derived from surface geologic maps, unit extent maps for each HSU, and a digital elevation model of the ground surface. The unit extent and outcrop maps were digitized and imported into EarthVision ${ }^{\circledR}$. Surfaces interpreted from 3-D seismic data were input directly into EarthVision ${ }^{\circledR}$. The pre-Tertiary surface derived from inversion of gravity-data (Section 2.3.5.1), was imported to help guide the construction of this surface in areas of limited data.

\subsubsection{Quality Control and Model Review}

The Phase II model was checked and modified as necessary by the SNJV and BN team members during model construction. This was an iterative process utilizing the capabilities of EarthVision ${ }^{\circledR}$ to cut profiles anywhere through the model, then interactively view individual or groups of HSU layers in 3-D, and visually compare various data sets such as drill hole tops and surface-grid points with HSU layers in the model. Traditional 2-D products such as structure contour maps and thickness maps were also produced from the model, and these were used to further evaluate the model. Modifications were made to address geometric conflicts, assure that geologic conventions were honored, assure conformation to drill hole, outcrop, and geophysical data, and incorporate geologic interpretations in areas of limited data. The various versions of the model produced during this process are electronically archived at the offices of SNJV in Las Vegas, Nevada. The final Frenchman Flat model, including alterative scenarios and electronic data sets, resides on workstations and electronic archival media at the offices of SNJV in Las Vegas, Nevada.

Computer-generated assessments of the final base model were conducted to statistically analyze and compare input data sets with computer-generated surfaces and grid points. These assessments show that computer-generated HSU surfaces tie well with the drill hole data 
(Figure 2-7), with associated errors typically less than $5 \mathrm{~m}(16.4 \mathrm{ft})$. Error associated with outcrop data is greater due to the complexity of the topographic surface, but is still considered to be relatively small.

Reviews of the model and alternatives were conducted within the UGTA pre-emptive review process as described in Section 2.4. A draft model documentation package (i.e., a draft of this report) was reviewed by a select group of pre-emptive review subcommittee members from LANL, LLNL, and USGS, and this final version of the package incorporates their comments.

\subsubsection{Alternative Models}

As briefly summarized in Sections 1.3.4 and discussed in more detail in Sections 3.0 and 4.0, the Frenchman Flat model area is geologically complex. Many of the major features within the valley are buried, and drill hole data are relatively sparse. Portions of the model are thus necessarily simplified, and represent non-unique solutions to the 3-D distribution of HSUs.

To address non-unique aspects of hydrologically significant interpretations within the base model, alternative interpretations were developed for portions of the base model. Ideas for alternative scenarios were conceived and evaluated during construction of the base model. The alternative models were constructed after the base model was completed, generally using the same model construction techniques. Each alternative model is equally bound by all the data and interpretation methods used for development of the base model. However, each alternative model is of limited geographic extent, and thus, affects only a portion of the base model. The alternatives can be thought of as fully functional, but geologically different, pieces of the base model that can be swapped into and out of the base model to test if the alternative interpretations can affect flow and transport.

An electronic copy of the base model was used in developing each alternative, and only those areas of the base model affected by the alternative interpretation were modified to produce the alternative model. Ultimately, four scenarios were selected for further development as alternative models, and eight scenarios were identified as alternative interpretations that would be better addressed later during hydrologic modeling. The UGTA pre-emptive review subcommittee participated in the development of alterative interpretations by reviewing the interpretations throughout the model construction process, including the final alternative interpretations. The process for addressing alternative interpretations is described in more detail, along with the interpretations themselves, in Section 5.0. 
Hydrostratigraphic

Units

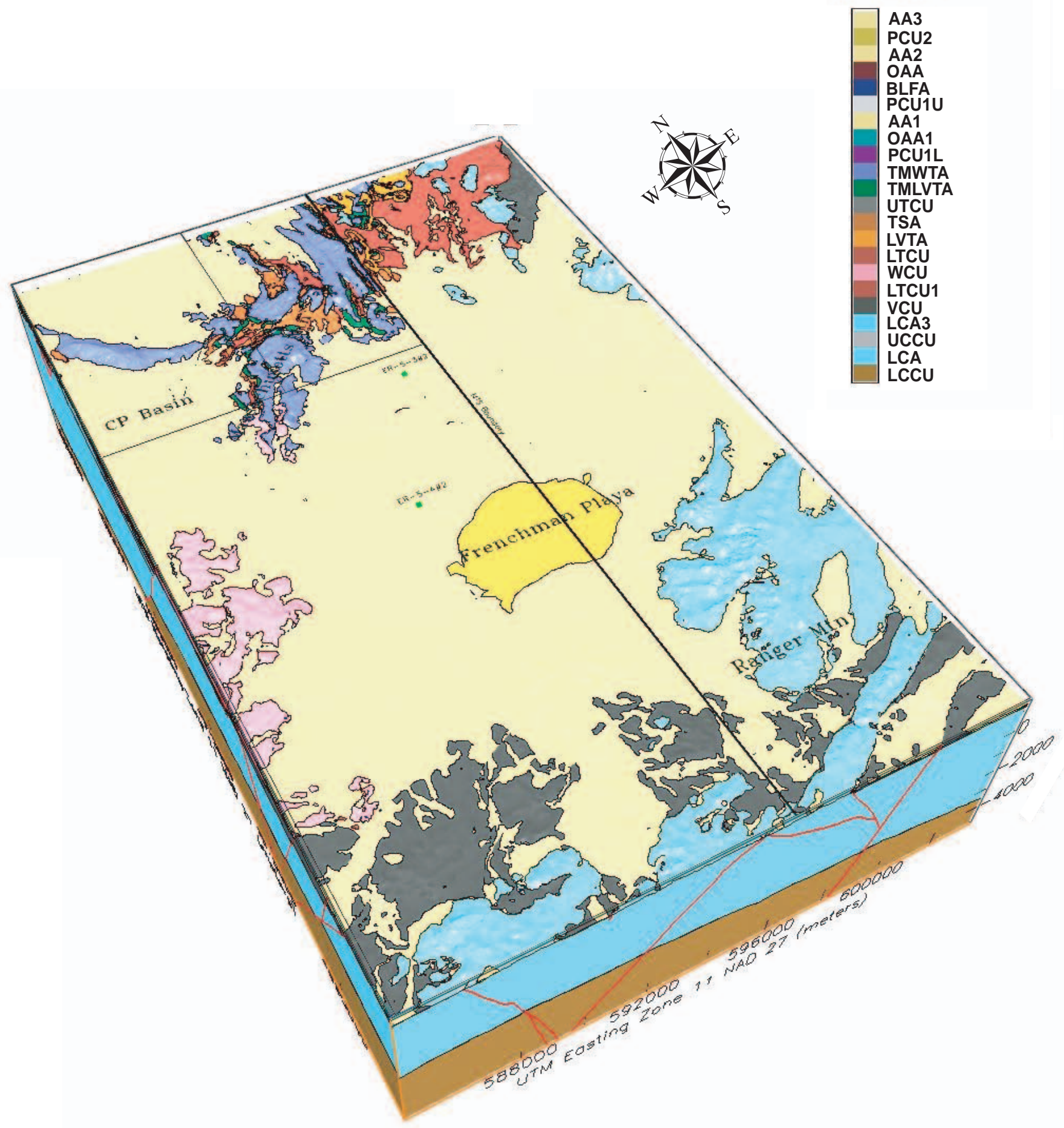

Figure 2-1

3-D Display from EarthVision ${ }^{\circledR}$ of the Model Volume 


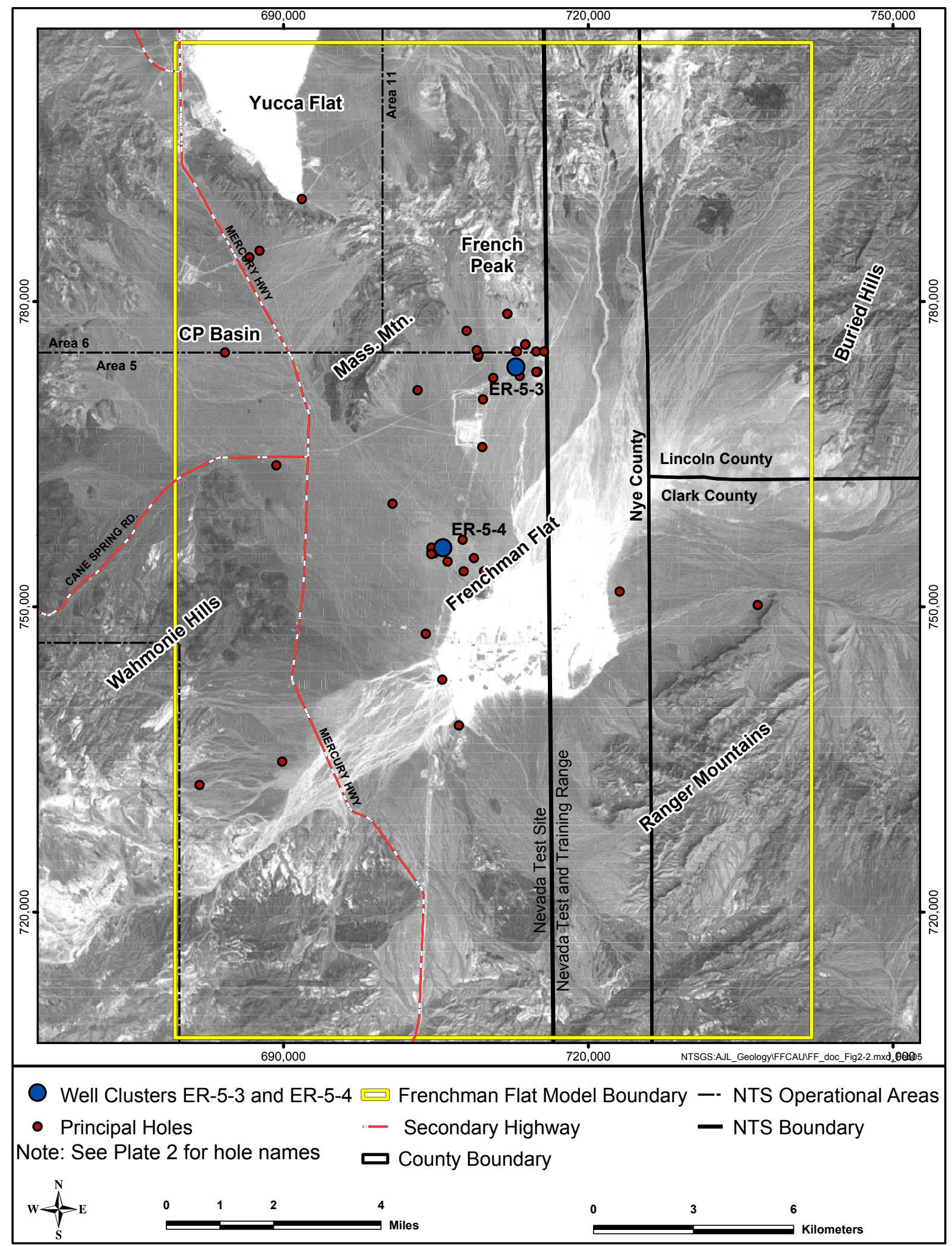

Figure 2-2

Locations of Drill Holes in the Frenchman Flat Model Area 


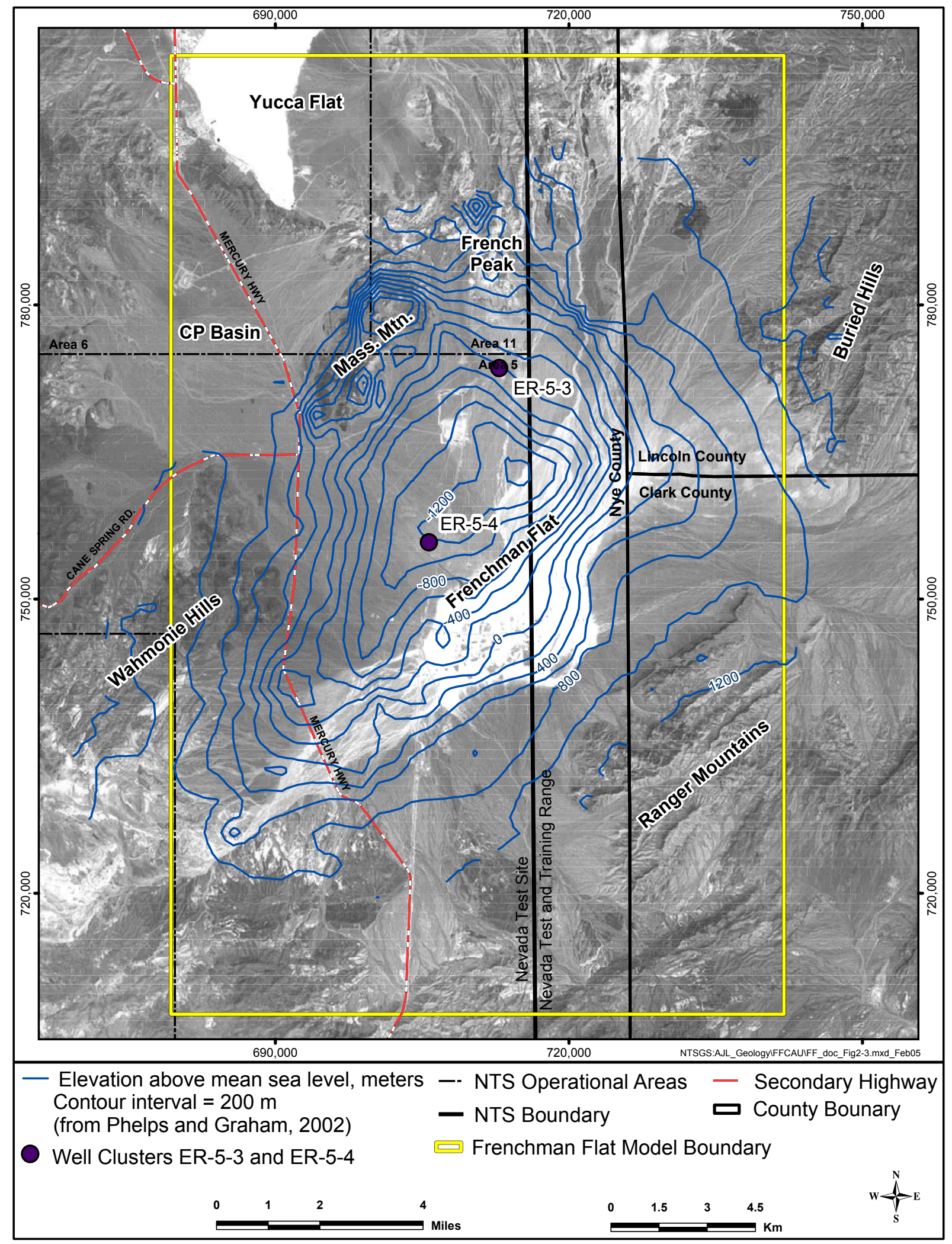

Figure 2-3

Elevation of Pre-Cenozoic Rocks Beneath Frenchman Flat Based on the Gravity Inversion Method 


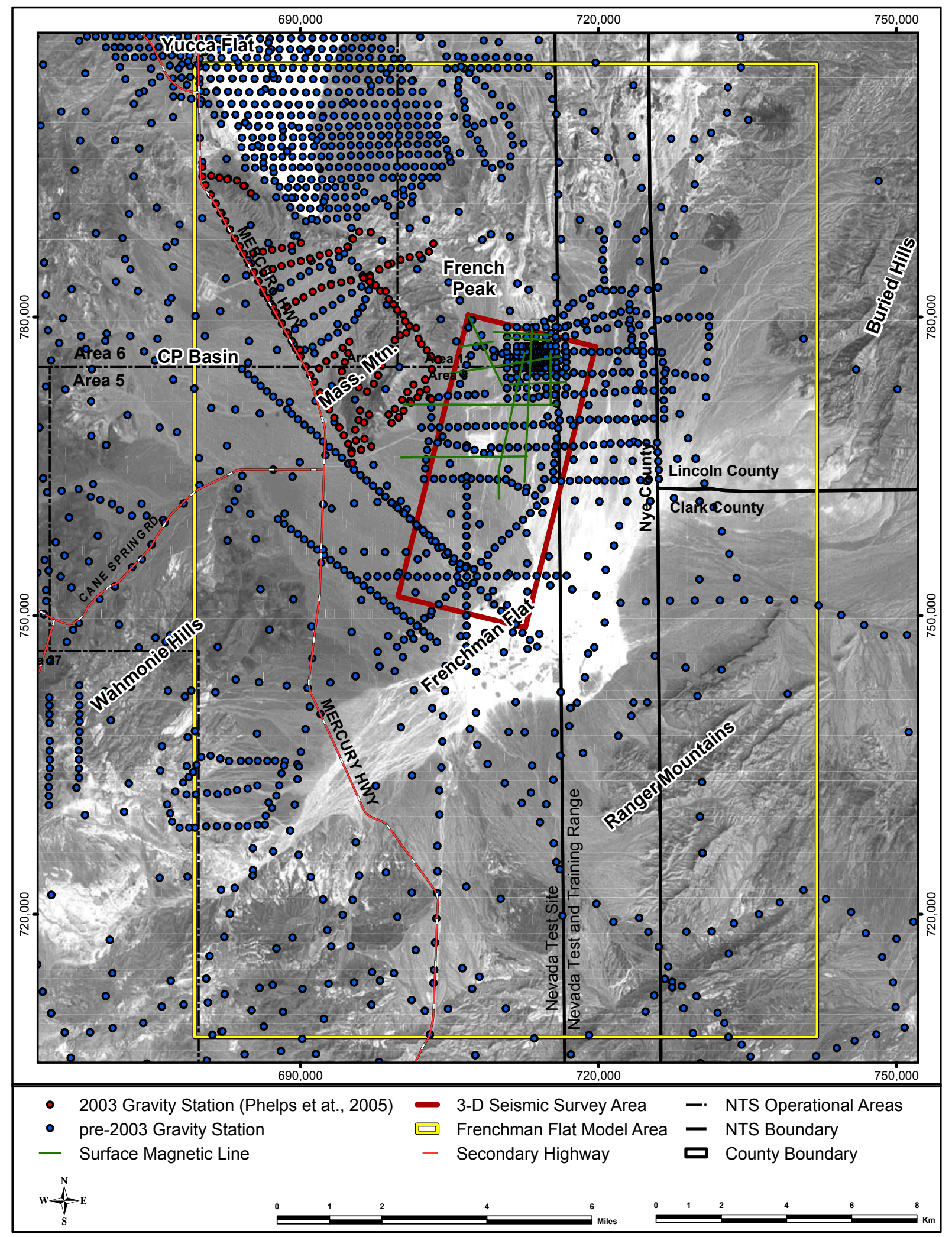

Figure 2-4

Locations of Gravity Stations and Surface Magnetic Lines in the Frenchman Flat Model Area 


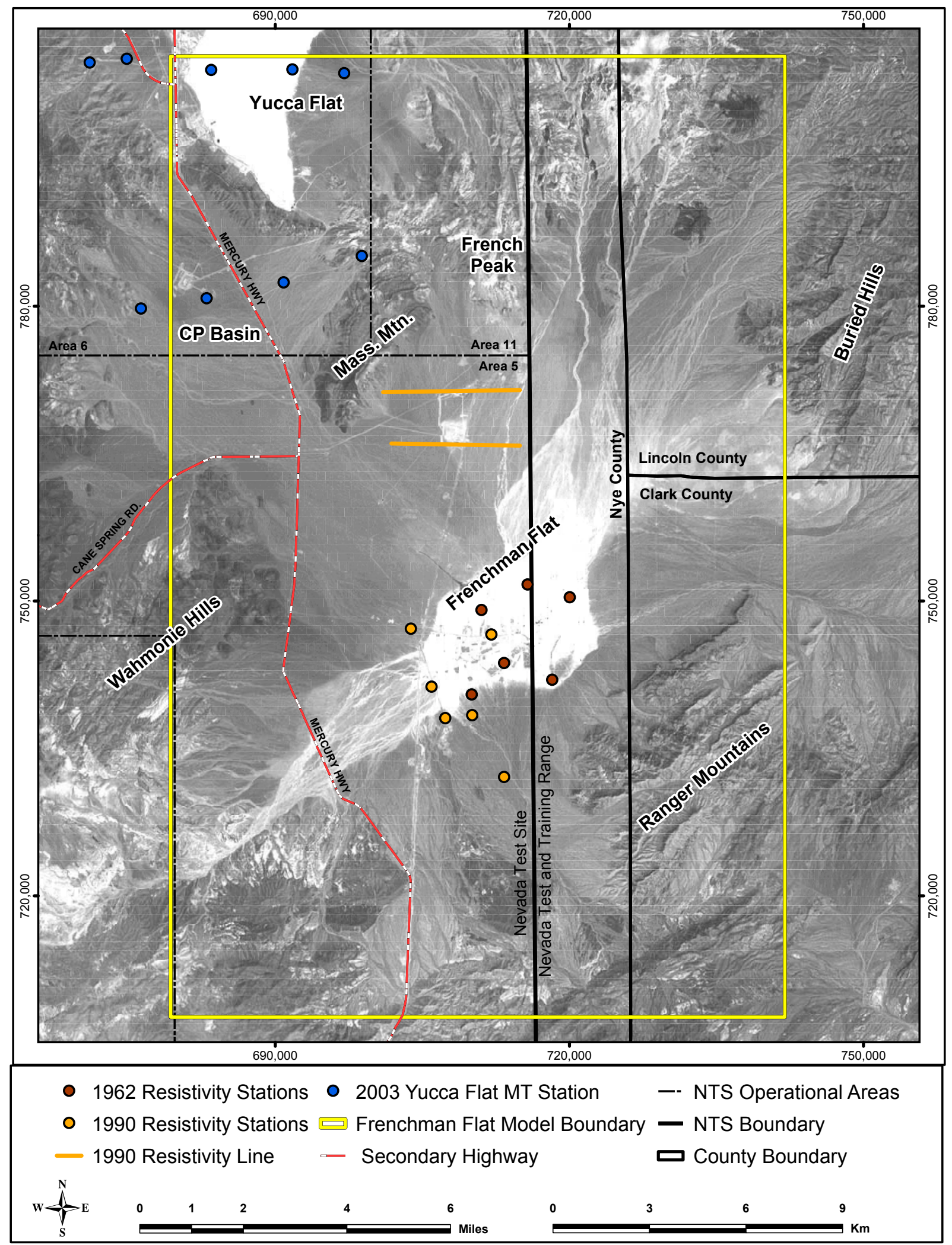

Figure 2-5

Locations of Resistivity Reciever Stations and Lines in the Frenchman Flat Model Area 


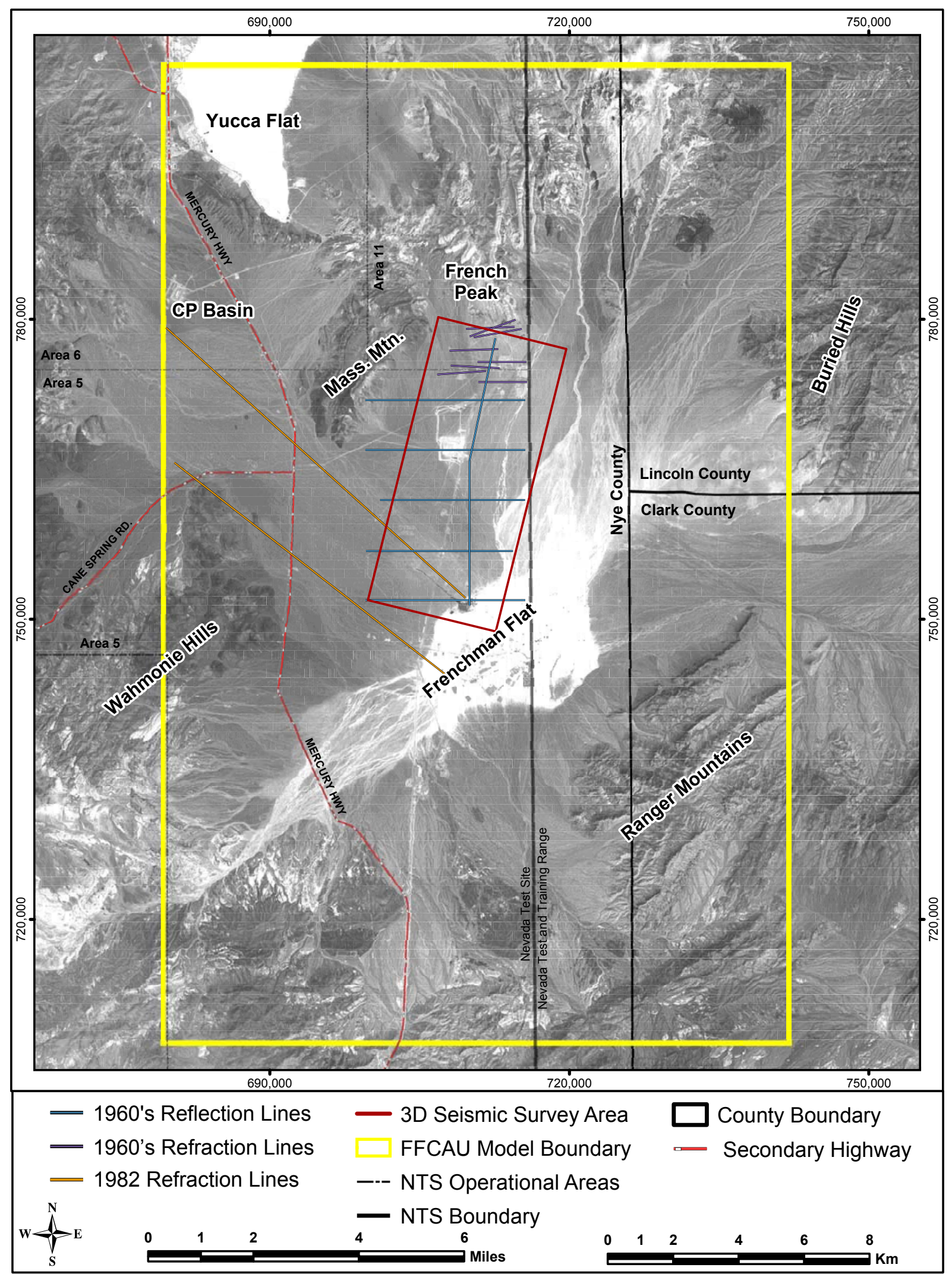

Figure 2-6

Locations of Seismic Surveys in the Frenchman Flat Model Area 


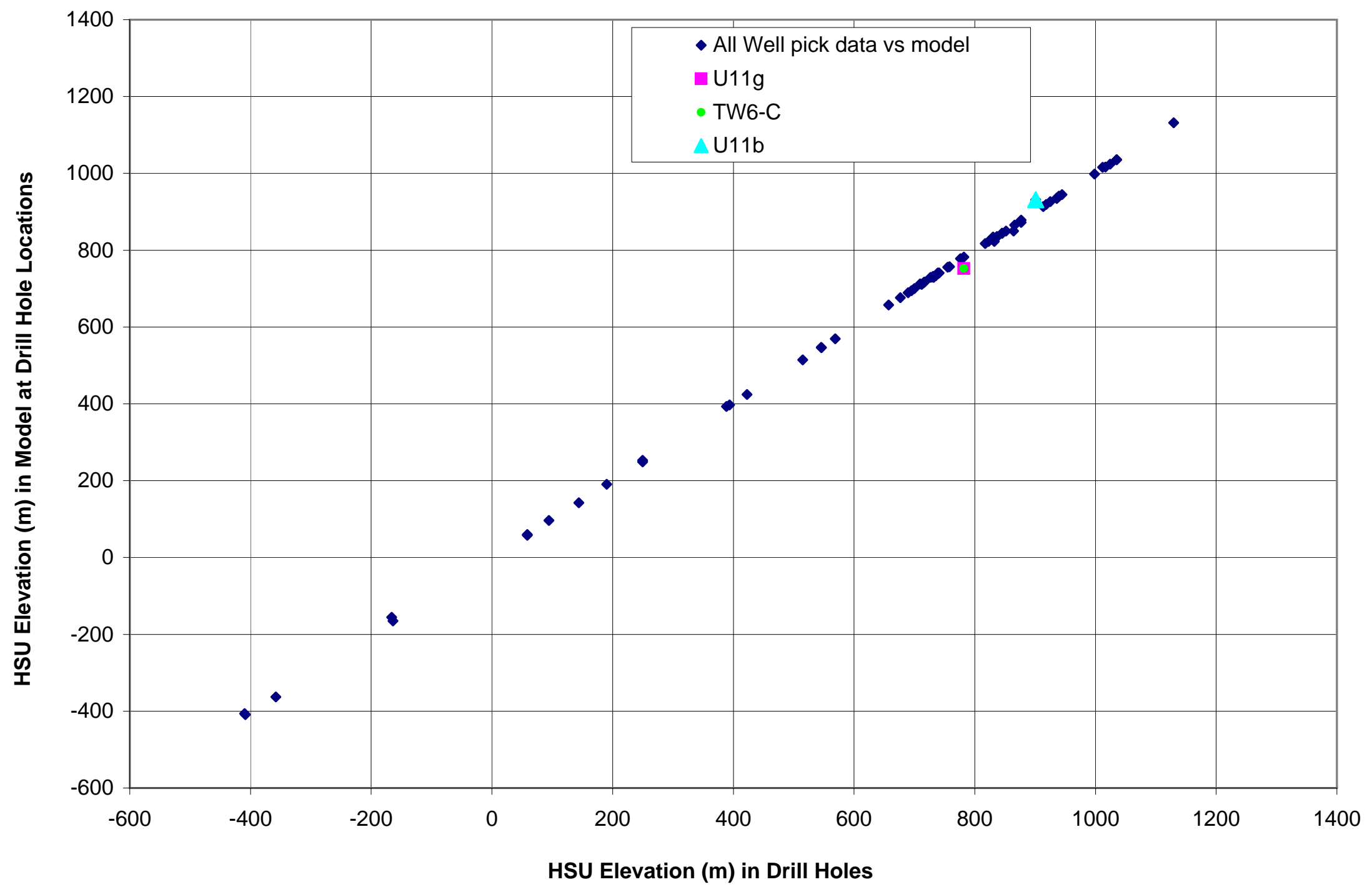

Figure 2-7

Model Assessment Chart Comparing HSU Tops in Drill Holes with HSU Tops Generated by EarthVision ${ }^{\circledR}$ in the Base Model 


\subsection{STRUCTURAL MODEL}

Geologic structures define the geometric configuration of the HSUs in the Frenchman Flat model area, including their distribution, thickness, and orientation, and thus are an important part of the hydrogeologic regime of the area. Basin-forming structures, including normal faults and some strike-slip faults, had a strong influence on depositional patterns of alluvial deposits and the extent, thickness, and structural elevation of volcanic deposits. Some faults place units with different hydrologic properties in juxtaposition, which may have significant hydrologic consequences. Also, the structures may themselves act as either conduits of groundwater flow, if they are characterized by open fractures, or barriers to flow, if associated with fine-grained gouge or increased alteration of nearby rocks. This section describes the structural elements of the model area, and includes discussions of how they were identified and spatially defined for the hydrostratigraphic framework model.

\subsection{Structural Overview}

The interpretation of the structural geology in the Frenchman Flat vicinity is difficult because complex pre-Tertiary contractional deformation has been overprinted by more recent extensional deformation. In addition, most of the major structural features are buried by thick deposits of volcanic rocks and alluvium. Fortunately, as described in Section 2.0, a rather large data set is available for Frenchman Flat that includes surface geologic exposures, drill hole data, and a variety of geophysical data. Recently acquired data, including deep drilling, 3-D seismic, and a new gravity inversion analysis, have proven valuable in better constraining the structural model of the basin.

\subsubsection{Pre-Tertiary Structure}

The pre-Tertiary rocks around the margins of Frenchman Flat show complex contractional structural relationships that include both east- and west-vergent thrusting and over-folding. South and east of Frenchman Flat the southeast-vergent Spotted Range thrust fault places Cambrian rocks over rocks as young as Mississippian (Barnes et al., 1982, Cole and Cashman, 1999). Northwest of CP Basin, Cambrian rocks have been thrust over Upper Mississippian and Pennsylvanian rocks along the west-vergent CP thust fault (McKeown et al., 1976; Caskey, 1991 and Cole and Cashman, 1999). The pre-Tertiary structural geology beneath Frenchman Flat however, is unknown. Only one hole within the basin (Well ER-5-3\#2) was drilled into preTertiary rocks, and very few coherent reflections were observed within the pre-Tertiary rocks in the seismic data (Prothro, 2002; Appendix D). 
Very little is also known about the pre-Tertiary structural geology beneath CP Basin. Analysis by BN geologists of the USGS MT measurements across CP Basin (Section 2.3.5.4) suggest that Mississippian rocks are thick but of limited extent beneath the basin. One interpretation of the MT data is that the Mississippian rocks dip very steeply beneath the eastern portion of the basin. Or Mississippian rocks may be present beneath the western portion of CP Basin, but not thick enough to be resolved by the MT method.

The timing of pre-Tertiary contractional deformation in the Frenchman Flat region is poorly constrained. Deformation must have occurred after the Pennsylvanian (less than 286 million years ago [Ma]) because rocks of this age are deformed within the footwall of the CP thrust fault northwest of CP Basin (McKeown et al., 1976; Caskey, 1991; and Cole and Cashman, 1999). Contractional deformation in the NTS region is probably older than Middle Cretaceous because approximately 100-Ma granite intrudes contractional structures in the northern portion of the NTS (Barnes et al., 1963; Gibbons et al., 1963; and Naeser and Maldonado, 1981).

\subsubsection{Development of Frenchman Flat Basin}

Gravity data show Frenchman Flat to be a northeast-oriented, tear-drop shaped basin, with its narrower end on the southwest (Figure 3-1). Steep gravity gradients along the south and east margins suggest the presence of major basin-forming faults in these areas. Structural attitudes of rocks exposed around the margins of Frenchman Flat also suggest that major basin-forming faults are located beneath the southern and eastern portions of the basin. Pre-Tertiary rocks are exposed extensively along the southern and eastern margins of the basin and generally dip east and southeast away from the basin. Along the western and northern margins of the basin thick sections of much younger volcanic rocks are exposed that generally dip southeast into the basin. Beneath the central portion of the basin, at Well ER-5-4\#2, these volcanic rocks occur at depths ranging from 1,120.4 $\mathrm{m}$ to more than 2,133.6 $\mathrm{m}$ (3,676 to more than 7,000 ft) (DOE, 2005b). Dip-meter analysis of the borehole image log from Well ER-5-4 \#2 and 3-D seismic data indicate that the volcanic rocks beneath the central portion of the basin dip approximately 30 degrees to the east-southeast (Prothro, 2002). This orientation is consistent with interpretations of seismic refraction (Pullammanappallil and Louie, 1994), 2-D seismic reflection (National Geophysical Company, Inc., 1966), and CSMAT data (Zonge, 1990), all of which indicate an eastward tilt to units beneath the basin. In addition, 3-D seismic reflection data do not indicate any large faults offsetting the volcanic rocks beneath the central portion of the basin. Together, the surface geology, geophysical, and drill hole data provide strong evidence that Frenchman Flat is an east-southeast-tilted, half-graben-type basin with the main basin-forming faults located along its southern and eastern margins (Figure 3-2). 
Integration of Frenchman Flat site-specific geologic information with regional geologic information strongly suggests that the development of Frenchman Flat is related to movement along the Rock Valley fault zone located southwest of the model area. The Rock Valley fault zone is a system of east-northeast-striking, left-lateral faults that appear to be an offshoot of the Walker Lane-Las Vegas Valley shear zone. Several faults of the Rock Valley system are mapped at the surface in the southwestern portion of the model area (Barnes et al., 1982; Hinrichs, 1968), but appear to be covered by alluvium in the southern portion of the basin, indicating that the fault system continues northeastward beneath the southern portion of Frenchman Flat (see Plate 1). However, pre-Tertiary rocks exposed along the east side of Frenchman Flat are not disrupted by east-northeast-striking faults, which suggests that the Rock Valley fault zone terminates in the vicinity of Frenchman Flat. Pre-Tertiary rocks and associated high-angle normal faults exposed south and east of Frenchman Flat generally strike eastnortheast, south of the basin but curve and strike in a more northerly direction east of the basin. It is likely that the faults of the Rock Valley system follow this same trend beneath the southern and eastern portions of the basin. This would place the Rock Valley faults in the same general location and orientation as the steep gravity gradients, and suggests that the Rock Valley faults form the major basin-forming faults along the south and east sides of Frenchman Flat.

Complicating this general structural model is the recognition of a previously unknown northwest-striking, down-to-the-southwest fault zone beneath the northern portion of the basin. This fault zone, which was identified with 3-D seismic reflection data, displaces the Paleozoic rocks as much as $600 \mathrm{~m}(2,000 \mathrm{ft})$, resulting in a structural platform beneath the northern portion of the basin (Figure 3-2; Appendix D, Figures D.4-22 and D.4-24). Though subtle, this structural feature is also observed on the gravity data (Figure 2-3). Due to the large amount of displacement associated with this fault zone it is interpreted to be related to basin development and therefore is also likely related to the large basin-forming faults interpreted to be present along the south and east margins of the basin. If this is the case, then the faults of the Rock Valley system must not only curve to the north but also continue to curve to the northwest forming a fan-shaped fault pattern. This fan-shaped pattern of basin-forming faults results in the overall tear-drop shape of the basin as observed in the gravity data.

The beginning of the main period of basin development for Frenchman Flat is well constrained. No sedimentary units are recognized within the volcanic section between the Crater Flat Group (13.25 Ma) and Ammonia Tanks Tuff (11.45 Ma). In addition, 3-D seismic reflection data show no stratigraphic relationships within this portion of the volcanic section characteristic of growthfaulting, such as increasing stratigraphic dip with depth or consistent directional thickening of volcanic units. Basalt flows intercalated within alluvium in drill holes UE-5i and UE-5k have 
been dated at 8.6 and 8.4 Ma, respectively (RSN, 1994), indicating that basin development had begun well before approximately 8.5 Ma in northern Frenchman Flat. However, at UE-5i, $3.0 \mathrm{~m}$ $(10 \mathrm{ft})$ of colluvium consisting of subangular to rounded gravel-sized clasts of mostly tuff and lesser quartzite (Dixon et al., 1967), occurs between the Ammonia Tanks Tuff and an overlying ash-flow tuff related to the Thirsty Canyon Group (9.14 to 9.4 Ma). Additionally, at Well ER-5-4 a thin ash-bed related to the Thirsty Canyon Group (Warren et al., 2002) occurs within the alluvium $293.5 \mathrm{~m}$ (963 ft) above the top of the Ammonia Tanks Tuff (DOE, 2005b). These stratigraphic relationships further constrain the onset of major basin development to some time after the eruption of the Ammonia Tanks Tuff (11.45 Ma) and before the end of the eruptive cycles of the Thirsty Canyon Group (9.14 Ma). Quaternary fault scarps in southern Frenchman Flat (Poole, 1965) and recent earthquake activity in the Frenchman Flat area, including the along Rock Valley fault zone (Anderson et al., 1993 and Fischer et al., 1972), suggest basin development may continue into the present.

Although the main period of basin development in Frenchman Flat occurred after the eruption of the Ammonia Tanks Tuff (11.45 Ma), the distribution of the older Tertiary units indicates that a Frenchman Flat proto-basin may have existed prior to, and contemporaneous with, the initial eruptions of the southwestern Nevada volcanic field (SWNVF). A thick, diverse assemblage of rocks ranging in age from approximately 18 to $13.25 \mathrm{Ma}$ is exposed in a rather narrow band that coincides with the Rock Valley fault zone in the southwestern portion of Frenchman Flat (Prothro and Drellack, 1997). This assemblage consists of sedimentary rocks deposited in fluvial and lacustrine environments, and intercalated volcanic rocks associated with the initial eruptions of the SWNVF. The presence of these rocks along the fault zone may indicate that movement along the Rock Valley fault prior to the development of the main basin produced a depositional center aligned with the trace of the fault system. The fault trace appears to continue north-eastward beneath the southern portion of Frenchman Flat. The occurrence of more than $610 \mathrm{~m}$ (2,000 ft) of Wahmonie Formation in Well ER-5-4\#2 (DOE, 2005b) may indicate that as late as $13.0 \mathrm{Ma}$, volcanic units were continuing to fill this pre-existing proto-basin.

In summary, the formation of Frenchman Flat appears to be directly related to the northeastern termination of the Rock Valley fault zone within an extensional imbricate fan. The formation of this fan structure has resulted in a series of oblique-slip faults that flare out to the north and northwest from the Rock Valley fault zone. These faults drop the basin down along the south, east, and north, forming an east-tilted half-graben-type basin beneath the central portion of Frenchman Flat and a structural platform beneath the northern portion. The main period of basin development appears to have begun between 11.45 and 9.14 Ma, and may continue into the present. 


\subsection{Structural Elements}

The primary structural elements within the Frenchman Flat model are high-angle faults. Other structural features in the model include thrust and detachment faults. These structural elements are described in the following subsections.

\subsubsection{Thrust Faults}

No thrust faults are exposed within the boundaries of the model area. However, as mentioned in Section 3.1.1, the CP and Spotted Range thrust faults are exposed just northwest and southeast of the model area, and their orientations suggest that both faults are likely present at depth within the model area.

The southeast-vergent Spotted Range thrust fault places carbonate rocks of Cambrian age over carbonate rocks as young as Mississippian (Barnes et al., 1982). Because the fault juxtaposes rocks of similar hydrologic character (i.e., carbonate aquifer over carbonate aquifer) where mapped at the surface southeast of the model area, and because of uncertainty about the nature and location of the fault at depth within the model area, the Spotted Range fault was not delineated within the framework model.

The CP thrust fault is exposed in the hills just west of the northwest corner of the model area. This west-vergent fault places mostly carbonate rocks of Cambrian age over Mississippian- and Pennsylvanian-age units that include fine-grained siliciclastic (i.e., clastic confining unit) and carbonate rocks (McKeown et al., 1976; Caskey, 1991 and Cole and Cashman, 1999). Because the fault juxtaposes rocks with significantly different hydrologic character, the CP thrust fault was modeled at depth within the framework model.

Very little is known about the CP thrust fault within the model area. No drill holes penetrate the fault and geophysical methods have been mostly unsuccessful in delineating it. However, MT data have proven successful in Yucca Flat in estimating the thickness and extent of Mississippian-age fine-grained siliciclastic rocks that compose the footwall of the CP thrust fault in the vicinity of the northwest portion of the Frenchman Flat model area. MT measurements across CP Basin show that Mississippian siliciclastic rocks are thick, but of limited lateral extent beneath the basin. These rocks occur at a depth of approximately 1,300 m (4,300 ft) and appear to be confined to the east side of the basin adjacent to the Cane Spring fault. MT data east of the Cane Spring fault do not indicate the presence of fine-grained siliciclatic rocks above 3,000 m (9,800 ft). In addition, information from Well ER-5-3\#2 (DOE, 2005a) and from a CSMAT survey (Zonge, 1990) in northern Frenchman Flat indicate that no pre-Tertiary fine-grained 
siliciclastic rocks occur above approximately 1,500 m (5,000 ft) in the northern portion of Frenchman Flat.

Because MT data suggest that fine-grained Mississippian rocks are present within the footwall of the CP thrust beneath CP Basin, the CP thrust fault was modeled beneath CP Basin. However, because no fine-grained pre-Tertiary rocks are indicated above approximately 1,500 m (5,000 ft) east of CP Basin in northern Frenchman Flat, the CP thrust fault was not modeled beneath Frenchman Flat. The CP fault may be present beneath Frenchman Flat, but if so, it occurs at depths greater than $1,500 \mathrm{~m}(5,000 \mathrm{ft})$. If it is shallower, the fault likely places carbonate rocks over other carbonate rocks, and thus, like the Spotted Range thrust fault, juxtaposes rocks of similar hydrologic character.

Beneath CP Basin the CP thrust fault is modeled as a southeast-dipping fault that is rooted in the northeast-striking Cane Spring fault. The thrust fault places carbonate rocks in the hanging wall over the steeply-dipping siliciclastic and carbonate rocks that compose the footwall. Because the CP thrust fault is poorly constrained in the model area, but may have a profound influence on the distribution of pre-Tertiary hydrostratigraphic units, an alternative interpretation of the thrust fault was developed (Section 5.5). This alternative models a more extensive and continuous sheet of Mississippian siliciclastic rocks within the footwall of the thrust fault beneath CP Basin.

\subsubsection{High-Angle Faults}

The most common structural feature in the model are high-angle normal faults related to basinand-range extension and basin formation. Although an early pre-volcanic extensional event that included the development of low-angle faults has been documented in the NTS region (Cole and Cashman, 1999), no such faults have been mapped in the model area and thus are not included in the model. Seventy-three high-angle faults are included in the framework model. Each fault is typically modeled as a single fault plane that dips approximately 75 degrees, and extends to the base of the model. Some faults, however, terminate against other faults. Almost all of the highangle faults are modeled with a component of dip-slip displacement, and most are probably best classified as normal faults. However, the apparent strong influence of strike-slip faulting on basin development likely results in many high-angle faults also having a component of strikeslip movement. Some faults, such as the Cane Spring fault and the main basin-forming faults along the southern margin of the basin, may have significant horizontal motion, and thus may best be classified as strike-slip faults.

The locations of the high-angle faults were determined on the basis of surface traces and geophysical evidence. Only the main surface faults were included in the model, and were 
digitized from surface geology maps (Hinrichs and McKay, 1965; Poole, 1965; Poole et al., 1965; Hinrichs, 1968; McKeown et al., 1976; Barnes et al., 1982; Workman et al., 2002). These faults typically have offsets greater than $61 \mathrm{~m}$ (200 ft) and appear to provide the main control on the structural fabric and outcrop patterns in the model area. Geophysically inferred high-angle faults include almost all the faults confidently identified in the 3-D seismic data. Other faults were inferred from seismic refraction and gravity data. The major basin-forming faults along the south and east sides of Frenchman Flat are inferred from gravity data and regional structural analysis. Therefore, the exact location, dip, and offset of these faults are poorly constrained, and the relative uncertainty of these features is thus higher than for most other faults in the model.

\subsubsection{Detachment Fault}

Evidence from 3-D seismic and drill hole data suggests that a detachment fault is present beneath the northern portion of Frenchman Flat (Prothro, 2002; Appendix D). Seismic reflections from the welded volcanic rocks (i.e. Ammonia Tanks Tuff, Rainier Mesa Tuff, and Topopah Spring Tuff) show a southeast-trending anticlinal feature within the volcanic rocks in the extreme northern portion of Frenchman Flat, between Drill Hole UE-11b and Well ER-5-3\#2 (see Appendix D). However, the anticlinal form does not extend downward to the top of the Paleozoic rocks, which are clearly expressed on the seismic data in this area. This large-scale disharmonic folding is common along listric normal faults, where such folds are referred to as rollover anticlines (Twiss and Moores, 1992). Rollover anticlines form in the hanging walls of concave-upward, listric normal faults as a result of the hanging wall strata tilting downward and deforming to maintain contact with the footwall of the fault. The disparity in depth to the volcanics between drill holes UE-11b and UE-11g ext 1 (338.6 vertical meters [1,111 ft] in 1,036.3 horizontal meters [3,400 ft]) and the shallow dip of the reflections of the volcanics here, indicate that the high-angle portion of the detachment fault is present between these two wells and that the dip of the fault shallows rapidly with depth to the south. It is likely that the detachment fault runs near the base of the Tertiary rocks and is rooted in the northwest-striking structural zone described previously. Because of the uncertainty of this interpretation and the potential hydrologic consequences associated with such an interpretation, an alternative model was developed that did not include the detachment fault, but modeled volcanic rocks as dipping steeply southward from UE-11b and nearby surface exposures to the deeper intercepts in drill holes located to the south (Section 5.3).

\subsection{Comparison with Phase I Model}

The structural models for the Phase I and II Frenchman Flat HSU framework models are similar in the general concept of basin development but differ considerably in detail. The structural model for the Phase I Frenchman Flat hydrostratigraphic framework model (IT, 1998) was 
developed by Grauch and Hudson (1995) in support of the UGTA hydrologic modeling project. It was based mainly on interpretation of gravity and aeromagnetic data, and like the Phase II model, depicted a series of basin-forming faults flaring out of the Rock Valley fault zone. However, the Phase I structural model depicted these faults as north-trending down-to-the-west normal faults that resulted in a series of east-tilted half grabens beneath the central portion of Frenchman Flat. This structural pattern is not reflected in the overall shape of the basin as indicated with the gravity data, and no such faults are observed in the 3-D seismic data beneath the central portion of the basin. As described previously, a large northwest-striking fault zone was observed on the seismic data in the northern portion of Frenchman Flat, suggesting that the larger basin-forming faults beneath Frenchman Flat strike northwest. This fault pattern provides a better fit with the gravity data.

Information from the 3-D seismic survey and from Wells ER-5-3\#2 and ER-5-4\#2 shows that the basin is deeper than modeled in the Phase I model. The maximum depth to pre-Tertiary rocks beneath Frenchman Flat in the Phase I model was 1,480 m (4,850 ft), versus 2,790 m (9,150 ft) in the Phase II model, which incorporates the more recent gravity, seismic, and drill hole data.

The Phase II model also includes a detachment fault beneath the northern portion of Frenchman Flat. This structural feature was not included in the Phase I model. However, a Phase II alternative model was developed that removes the detachment fault which is more consistent with the original Phase I model. 


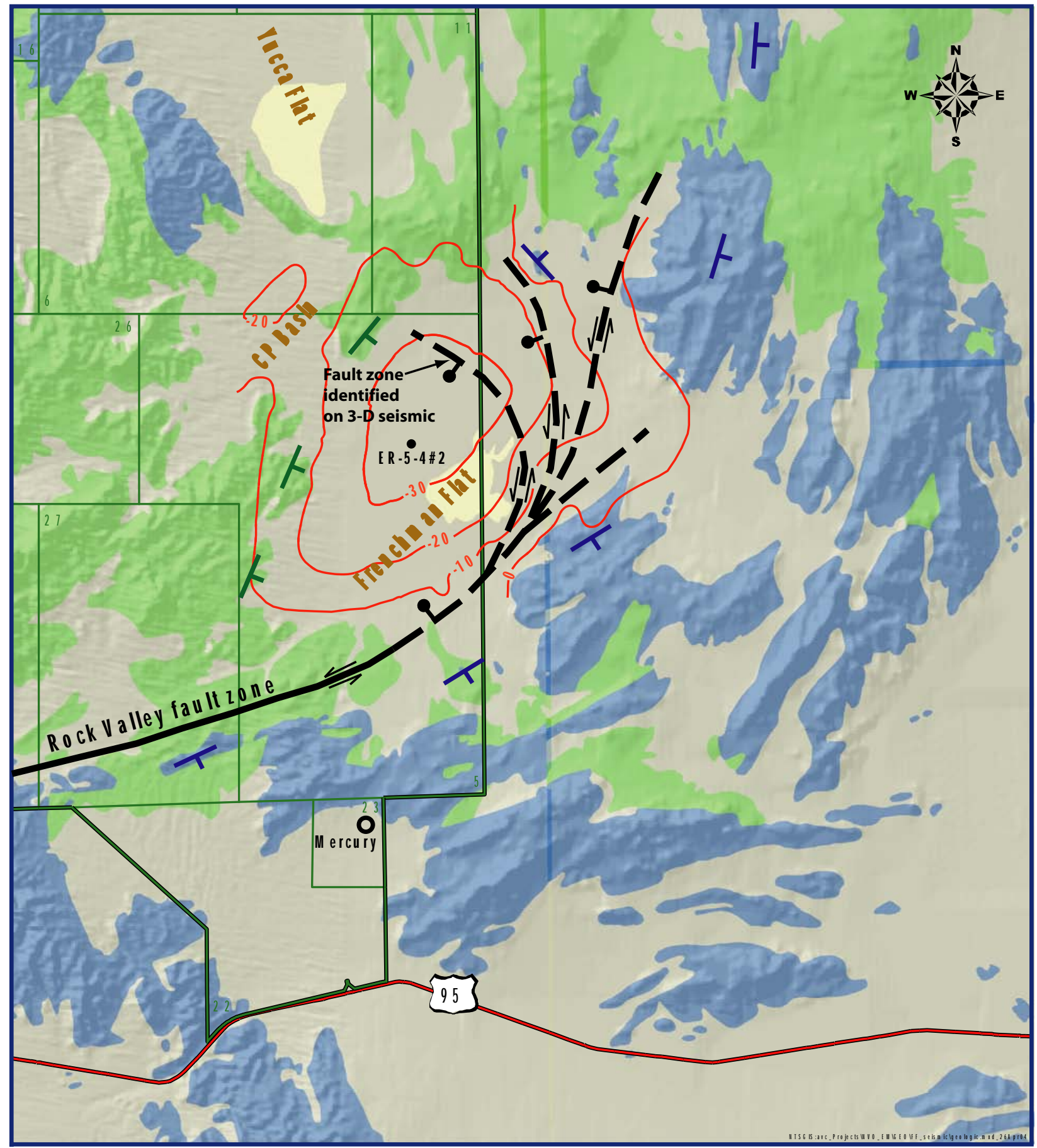

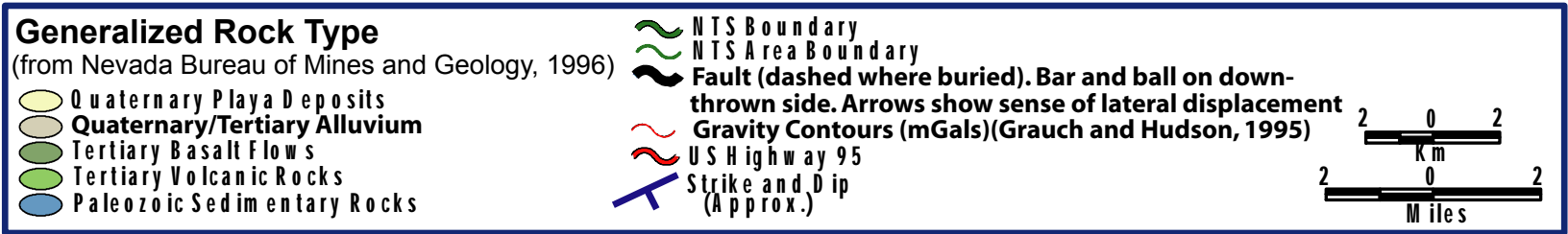

Figure 3-1

Generalized Geologic Map of Frenchman Flat and Vicinity Showing the Conceptual Structural Model of the Basin 


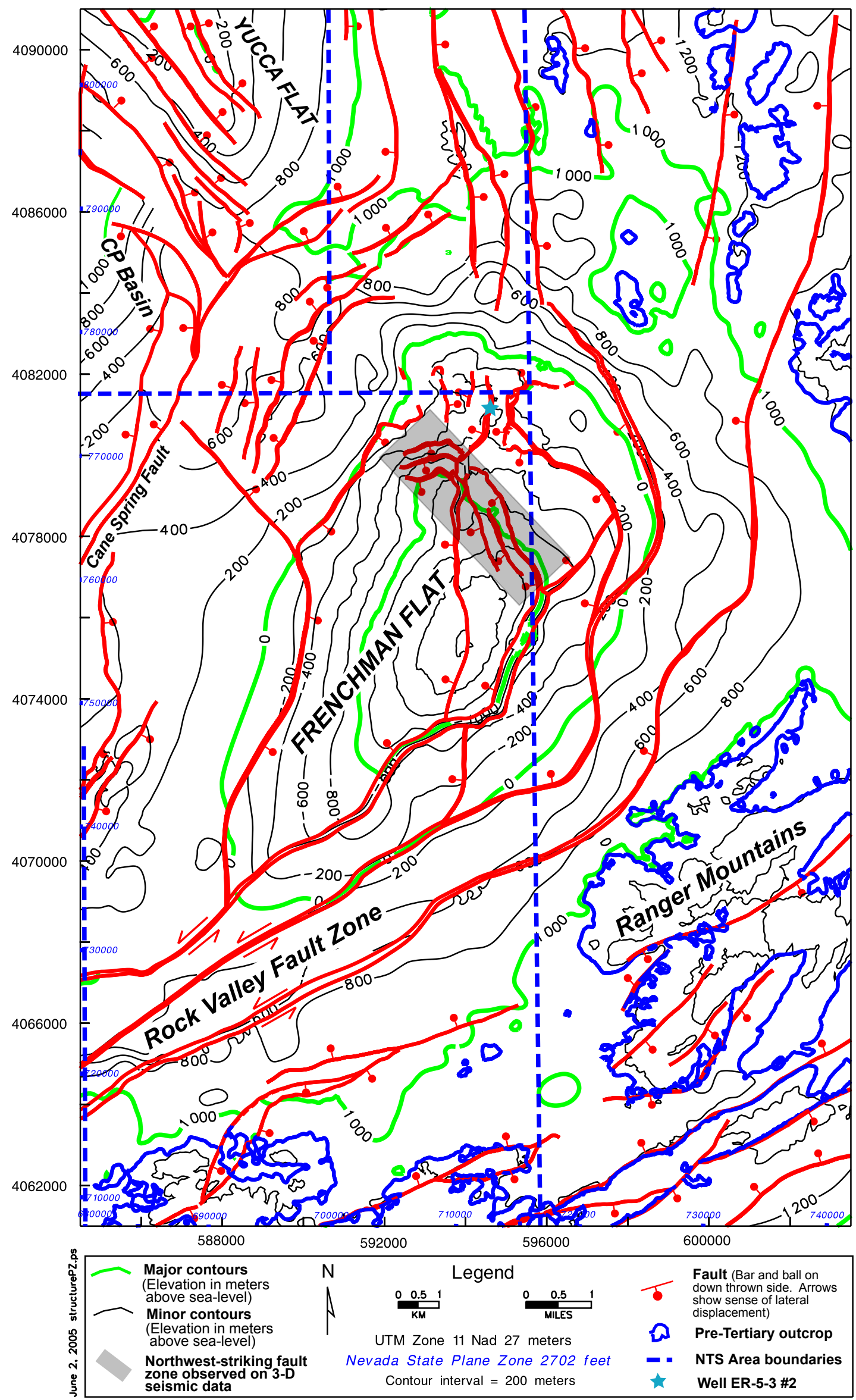

Figure 3-2

Structure Map for the Top of Pre-Tertiary Rocks in the Frenchman Flat Model Area (Map generated from the EarthVision ${ }^{\circledR}$ model) 


\subsection{HYDROSTRATIGRAPHY}

As introduced in Section 2.5, a hydrostratigraphic classification system for depicting the hydrologic character of complexly interfingering rocks of a wide range of lithologic and hydrologic characteristics was developed for use in the digital framework model for the Frenchman Flat area. The hydrogeologic framework for Frenchman Flat and vicinity established by Winograd and Thordarson (1975) provided the basis for developing the hydrostratigraphic system presented in this section.

\subsection{Development of the Hydrostratigraphic Classification System}

The development of the hydrostratigraphic classification system for the Frenchman Flat model area involved a three-step process. The first step was acquiring a thorough understanding of the character and three-dimensional distribution of the rocks, both lithologically and stratigraphically, within the model area. This critical first step was accomplished through a rigorous analysis of published surface geologic maps and descriptions, and drill hole and geophysical data.

In the second step, rocks in the Frenchman Flat area were classified as one of eight hydrogeologic units (HGUs) based on the rock's ability to transmit groundwater, which is mainly a function of a rock's primary lithology, type and degree of post-depositional alteration, and propensity to fracture. The most important factor affecting how groundwater flows through a body of rock is the rock's original primary lithology, which exerts a strong influence on the other two important processes, post-depositional alteration and fracturing. Hard, dense, brittle rocks such as welded tuff, lava, and carbonate generally have low primary porosity and permeability, but tend to fracture readily in response to tectonic forces and, as in the case of welded tuffs and lavas, also as a result of contraction during cooling. In addition, the low primary porosity and permeability of these rocks tend to inhibit significant secondary alteration such as zeolitization which typically changes the hydrologic character of the rocks. These rocks are considered aquifers and have been shown to be prolific water producers at the NTS. Less dense units such as alluvium, nonwelded tuff, and shale typically do not support extensive fracture systems and thus usually have low fracture-related effective porosity. However, some low density rocks such as nonwelded tuffs and alluvium can have relatively high primary effective porosity and these units are also considered aquifers where they are unaltered. The high primary effective porosity of these rocks, particularly nonwelded tuffs, makes them susceptible to post-depositional alteration precesses such as zeolitization, which can significantly 
reduce the effective porosity of altered rocks. Nonwelded tuffs that have undergone zeolitic alteration are considered confining units because of their very low effective porosity.

The third step in the development of the Frenchman Flat hydrostratigraphic classification system was to group individual HGUs of similar character into larger HSUs to facilitate mapping and 3-D model construction. A critical component of this step was the careful integration of Frenchman Flat stratigraphy. The integration of stratigraphic concepts is important to assure individual HGUs grouped within HSUs, and the HSUs themselves, properly correlate within the model. HSUs, therefore, can be thought of as groupings of contiguous stratigraphic units that have a particular hydrogeologic character, such as aquifer or confining unit. An HSU may consist of several HGUs, but is defined so that a single general type of HGU dominates (e.g., mostly welded-tuff and lava-flow aquifers, or mostly tuff confining units). HSUs serve as “layers” for the UGTA groundwater modeling process (IT, 1996c).

Sections 4.2 and 4.3 describe the stratigraphy and the HGUs of the Frenchman Flat area. Each of the 17 HSUs in the Frenchman Flat hydrostratigraphic framework model is described in Section 4.4.

\subsection{Stratigraphy of the Frenchman Flat Model Area}

To define appropriate HSUs to serve as layers in the framework model, the modelers had to start from a well understood stratigraphic system. Refinement of the stratigraphy of the NTS area, including Frenchman Flat, was a continuous process during the decades in which geoscientists associated with the WTP worked to understand the complex volcanic setting (Byers et al., 1989). The need to develop detailed geologic models in support of the UGTA program continued this process. The recognition of smaller and smaller distinct volcanic units permitted a greater understanding of the three-dimensional configuration of these rocks. Efforts to better understand the structure and stratigraphy of the pre-Tertiary sedimentary rocks have also continued throughout the UGTA program.

The stratigraphic section for the Frenchman Flat area consists of Paleozoic-age siliciclastic and carbonate rocks, Tertiary-age lacustrine and fluvial sedimentary rocks, Tertiary-age volcanic rocks, and Tertiary- and Quaternary-age alluvium (Hinrichs and McKay, 1965; Poole, 1965; Poole et al., 1965; Hinrichs, 1968; McKeown et al., 1976; Barnes et al., 1982) (Figure 4-1).

Paleozoic rocks are exposed in the mountains bordering Frenchman Flat on the northeast, east, and south. These rocks range in age from Cambrian to Mississippian. In northern Frenchman Flat, middle to upper Miocene-age volcanic rocks, that originated from vents located to the 
northwest of the basin, unconformably overlie Ordovician-age carbonate and siliciclastic rocks (Hinrichs and McKay, 1965; Prothro and Drellack, 1997). Southward, these volcanic units, including the Ammonia Tanks Tuff, Rainier Mesa Tuff, Topopah Spring Tuff, and Crater Flat Group, thin considerably and ultimately pinch out. The Crater Flat Group and older tuffs interfinger with coeval sedimentary rocks to the south and southeast (Poole, 1965; Poole et al., 1965; Hinrichs, 1968; Barnes et al., 1982; Prothro and Drellack, 1997). Upper to middle Miocene tuffs, lavas, and debris flows from the Wahmonie volcanic center, located west of Frenchman Flat, dominate the volcanic section beneath the western portion of the valley. To the south and southeast, most of the volcanic units are absent, and Oligocene to middle Miocene sedimentary and tuffaceous sedimentary rocks, which unconformably overlie the Paleozoic-age rocks in southern Frenchman Flat, dominate the Tertiary section (Hinrichs, 1968; Barnes et al., 1982; Prothro and Drellack, 1997). In most of the basin, upper Miocene to Holocene alluvium covers the older sedimentary and volcanic rocks (Hinrichs and McKay, 1965; Poole, 1965; Poole et al., 1965; Hinrichs, 1968; McKeown et al., 1976; Barnes et al., 1982; Slate, 1999).

Table 4-1 lists the Quaternary and Tertiary stratigraphic units of the Frenchman Flat model area. Table 4-2 lists the pre-Tertiary units.

\subsection{Hydrogeologic Units of the Frenchman Flat Model Area}

The data documentation package prepared for the previous CAU-scale hydrostratigraphic framework model (Pahute Mesa - Oasis Valley area; see BN, 2002) included a separate section that addressed expected hydraulic properties of the HGUs included in the model. However, separate data documentation packages have been developed specifically for Frenchman Flat hydrology, transport parameter, and source term data (for example, SNJV, 2004b, 2005a, 2005b), which address the ranges of parameter values hydrologic modelers will use as they explore groundwater flow and contaminant transport using this hydrostratigraphic framework model. This document thus does not include a section specifically addressing hydraulic properties, but the following paragraphs and Table 4-3 provide general information to aid in the reader in understanding the hydrologic character of each HGU.

All the rocks of the Frenchman Flat model area are classified as one of the following eight HGUs: playa confining unit, alluvial aquifer, welded-tuff aquifer, vitric-tuff aquifer, lava-flow 
Table 4-1

Quaternary and Tertiary Stratigraphic Units of the Frenchman Flat Model Area

\begin{tabular}{|c|c|}
\hline Stratigraphic Assemblages and Major Units ${ }^{a}$ & Volcanic Sources $^{b}$ \\
\hline $\begin{array}{l}\text { Quaternary and Tertiary Sediments } \\
\text { Young playa deposits (Qp) } \\
\text { Young alluvium (Qay) } \\
\text { Quaternary - Tertiary colluvium (QTc) } \\
\text { Intermediate alluvium (Qai) } \\
\text { Quaternary-Tertiary alluvium (QTa) } \\
\text { Pliocene Basalts (Tybf) } \\
\text { Older playa deposits (QTp) } \\
\text { Tertiary alluvium (QTa) }\end{array}$ & Not applicable \\
\hline $\begin{array}{c}\text { Thirsty Canyon Group (Tt) } \\
\text { Pahute Mesa Tuff (Ttp) }\end{array}$ & Black Mountain Caldera \\
\hline $\begin{array}{l}\text { Timber Mountain Group (Tm) } \\
\text { Ammonia Tanks Tuff (Tma) } \\
\text { bedded Ammonia Tanks Tuff (Tmab) } \\
\text { Rainier Mesa Tuff (Tmr) } \\
\text { Tuff of Holmes Road (Tmrh) }\end{array}$ & $\begin{array}{l}\text { Timber Mountain Caldera Complex } \\
\text { Ammonia Tanks Caldera } \\
\text { Rainier Mesa Caldera }\end{array}$ \\
\hline $\begin{array}{l}\text { Paintbrush Group (Tp) } \\
\text { Tiva Canyon Tuff (Tpc) } \\
\text { Topopah Spring Tuff (Tpt) } \\
\end{array}$ & $\begin{array}{c}\text { Claim Canyon Caldera } \\
\text { Unknown }\end{array}$ \\
\hline Calico Hills Formation (Th; formerly Tac) & Unknown \\
\hline $\begin{array}{l}\text { Wahmonie Formation (Tw) } \\
\text { Upper Member (Twu) } \\
\text { Middle Member (Twm) } \\
\text { Lower Member (Twl) } \\
\text { Tuff of Wahmonie Flat (Twlb) } \\
\text { Salyer Member (Twls) }\end{array}$ & Wahmonie Volcanic Center \\
\hline $\begin{array}{l}\text { Crater Flat Group (Tc) } \\
\text { Prow Pass Tuff (Tcp) } \\
\text { Bullfrog Tuff (Tcb) } \\
\text { Tram Tuff (Tct) } \\
\text { Belted Range Group (Tb) } \\
\text { Grouse Canyon Tuff (Tbg) }\end{array}$ & $\begin{array}{l}\text { Silent Canyon Caldera Complex } \\
\text { Area } 20 \text { Caldera } \\
\text { Grouse Canyon Caldera }\end{array}$ \\
\hline Tunnel Formation (Tn) & Unknown \\
\hline Older volcanics (Tqo) & Unknown \\
\hline $\begin{array}{l}\text { Older Tuffaceous Sedimentary Rocks }{ }^{c} \\
\text { Rocks of Pavits Spring (Tgp) }{ }^{d} \\
\text { Rocks of Winapi Wash (Tgw) }\end{array}$ & $\begin{array}{l}\text { Unknown } \\
\text { Not Applicable }\end{array}$ \\
\hline
\end{tabular}


Table 4-1 (continued)

Quaternary and Tertiary Stratigraphic Units of the Frenchman Flat Model Area

a Compiled from Slate et al. (1999) and Ferguson et al. (1994). Letters in parentheses are stratigraphic unit map symbols.

b Sources, where known, from Sawyer et al. (1994)

c Prothro and Drellack, 1997

d Proposed symbol: Tg after Wahl et al., 1997

e Informal unit, after Yount (1996). Formerly the Horse Spring Formation

Table 4-2

Pre-Tertiary Stratigraphic Units of the Frenchman Flat Model Area

(Stratigraphic and lithologic units adapted from Cole, 1992)

\begin{tabular}{||l|c|c|c|l||}
\hline \multicolumn{1}{||}{ Map Unit } & $\begin{array}{c}\text { Stratigraphic } \\
\text { Unit Map } \\
\text { Symbol }\end{array}$ & \multicolumn{2}{|c|}{$\begin{array}{c}\text { Stratigraphic } \\
\text { Thickness } \\
\text { Feet }\end{array}$} & Meters
\end{tabular}


Table 4-3

Hydrogeologic Units of the Frenchman Flat Model

Adapted from Winograd and Thordarson (1975); IT (1996a); and Laczniak et al. (1996)

\begin{tabular}{|c|c|c|}
\hline Hydrogeologic Unit & Typical Lithologies & Hydrologic Significance \\
\hline $\begin{array}{l}\text { Playa Confining Unit } \\
\text { (PCU) }\end{array}$ & Clayey-silt, sandy-silt & $\begin{array}{l}\text { Near-surface confining unit at Frenchman } \\
\text { Lake and at base of alluvium in deepest } \\
\text { portion of Frenchman Flat. May also limit, or } \\
\text { redirect, recharge where present at surface. }\end{array}$ \\
\hline $\begin{array}{l}\text { Alluvial aquifer } \\
\text { (AA) } \\
\text { (AA is also an HSU } \\
\text { in the Frenchman Flat } \\
\text { framework model.) }\end{array}$ & $\begin{array}{l}\text { Unconsolidated to partially } \\
\text { consolidated gravelly sand, } \\
\text { eolian sand, and colluvium; }\end{array}$ & $\begin{array}{l}\text { Has characteristics of a highly conductive } \\
\text { aquifer, but less so where lenses of clay-rich } \\
\text { paleocolluvium, zeolitic alteration, or playa } \\
\text { deposits are present. }\end{array}$ \\
\hline $\begin{array}{l}\text { Welded-tuff aquifer } \\
\text { (WTA) }\end{array}$ & $\begin{array}{l}\text { Welded ash-flow tuff; vitric to } \\
\text { devitrified }\end{array}$ & $\begin{array}{l}\text { Degree of welding greatly affects interstitial } \\
\text { porosity (i.e., less porosity as degree of } \\
\text { welding increases) and permeability (i.e., } \\
\text { greater fracture permeability as degree of } \\
\text { welding increases). }\end{array}$ \\
\hline $\begin{array}{l}\text { Vitric-tuff aquifer } \\
\text { (VTA) }\end{array}$ & $\begin{array}{l}\text { Bedded tuff; ash-fall and } \\
\text { reworked tuff; vitric }\end{array}$ & $\begin{array}{l}\text { Constitutes a volumetrically minor HGU. } \\
\text { Generally does not extend far below the static } \\
\text { water level due to tendency of tuffs to } \\
\text { become zeolitic under saturated conditions, } \\
\text { which drastically reduces permeability. } \\
\text { Significant interstitial porosity (i.e., } 20 \text { to } 40 \\
\text { percent). Generally insignificant fracture } \\
\text { permeability. }\end{array}$ \\
\hline $\begin{array}{l}\text { Lava-flow aquifer } \\
\text { (LFA) }\end{array}$ & Basalt and dacite lava flows & $\begin{array}{l}\text { Generally as thin local flows. Hydrologically } \\
\text { complex; wide range of transmissivities; } \\
\text { fracture density and interstitial porosity differ } \\
\text { with lithologic variations. }\end{array}$ \\
\hline $\begin{array}{l}\text { Tuff confining unit } \\
\text { (TCU) }\end{array}$ & $\begin{array}{l}\text { Zeolitic bedded tuff with } \\
\text { interbedded, but less } \\
\text { significant, zeolitic, } \\
\text { nonwelded to partially } \\
\text { welded ash-flow tuff }\end{array}$ & $\begin{array}{l}\text { May be saturated, but measured } \\
\text { transmissivities are very low. May cause } \\
\text { accumulation of perched and/or semi- } \\
\text { perched water in overlying units. }\end{array}$ \\
\hline $\begin{array}{l}\text { Clastic confining unit } \\
\text { (CCU) }\end{array}$ & Argillite, siltstone, quartzite & $\begin{array}{l}\text { Clay-rich rocks are relatively impermeable; } \\
\text { coarser-grained siliceous rocks are fractured, } \\
\text { but with fracture porosity generally sealed } \\
\text { due to secondary mineralization. }\end{array}$ \\
\hline $\begin{array}{c}\text { Carbonate aquifer } \\
\text { (CA) }\end{array}$ & Dolomite, limestone & $\begin{array}{l}\text { Transmissivity values vary greatly, and are } \\
\text { directly dependent on degree of fracturing } \\
\text { and dissolution. }\end{array}$ \\
\hline
\end{tabular}


aquifer, tuff confining unit, clastic confining unit, and the carbonate aquifer. These are summarized in Table 4-3 and described in the following paragraphs.

\subsubsection{Alluvial HGUs}

Two alluvial HGUs are recognized in the Frenchman Flat model area: the alluvial aquifer (AA; also an HSU) and the playa confining unit. The AA consists mainly of gravelly sand and sandy gravel eroded from the surrounding mountains during the main period of basin development, and deposited on alluvial fans by debris flow and sheet-flood processes. Deposits of finer-grained eolian sand are intercalated within the coarser alluvial deposits. The playa confining unit consists of fine-grained sand, silt, and clay deposited as playa lake sediments in the topographic low point of the basin. Descriptions for these two HGUs are included in the subsections for the similarly named HSUs (Sections 4.4.1, 4.4.2, and 4.4.3).

\subsubsection{Volcanic HGUs}

The volcanic rocks within the study area are categorized into four HGUs based on primary lithologic properties, degree of fracturing, and secondary mineral alteration. In general, the altered volcanic rocks, which are typically zeolitized, act as confining units, and the unaltered rocks form aquifers. The aquifer units can be further divided into welded-tuff and vitric-tuff aquifers, depending on degree of welding, and lava-flow aquifers. Denser rocks, such as welded ash-flow tuffs and lava flows, tend to fracture more readily, and therefore have relatively high permeability (Blankennagel and Weir, 1973; Winograd and Thordarson, 1975; Laczniak et al., 1996; IT, 1996a; Prothro and Drellack, 1997).

\subsubsection{Pre-Tertiary HGUs}

The hydrogeology of the pre-Tertiary sedimentary rocks at the NTS follows the framework developed by Winograd and Thordarson (1975), and used in the Phase I regional modeling effort (IT, 1996a, 1996b, 1996c, 1996d) and subsequent CAU-scale models (BN, 2002; Gonzales et al., 1998). Within the study area, pre-Tertiary rocks are categorized as aquifer or confining unit HGUs based on lithology. The siliceous clastic rocks, such as quartzite, siltstone, and shale, are classified as clastic confining units. Carbonate rocks such as limestone and dolomite are classified as carbonate aquifers (Winograd and Thordarson, 1975; Laczniak et al., 1996).

\subsection{Hydrostratigraphic Units for the Frenchman Flat Model}

The following paragraphs describe all the HSUs in the Frenchman Flat hydrostratigraphic framework model. They are generally listed in descending order from the top of the model to the bottom. However, some HSUs are laterally rather than vertically contiguous, and not all units are present in all parts of the model area. A summary of the characteristics of each of the 
17 HSUs of the Frenchman Flat model is given in Table 4-4. Table 4-5 shows the correlation of Frenchman Flat HSUs with HSUs of other hydrostratigraphic framework models of the region.

The geometric configuration of the HSUs as defined in the model is represented as 3-D perspective views and 2-D plan maps and profiles in various figures throughout this report. Contour maps showing the depth to the top of selected aquifer HSUs are introduced as necessary to aid in the description of these HSUs. The correlation of stratigraphic units and hydrostratigraphic units of the Frenchman Flat model area is depicted graphically in Figure 4-2. Figure 4-3 is a HSU surface map (see also Plate 2) and Figure 4-4 is a HSU "basement" sub-crop map. Profiles A-A' through E-E', which illustrate the relationships of the HSUs and structures in various vertical planes, can be found in Appendix C.

\subsubsection{Alluvial Aquifer (AA, AA3, AA2, AA1)}

This HSU consists of Quaternary- and Tertiary-age basin-filling alluvium such as that mapped at the surface in the central portions of Frenchman Flat and CP Basin (Qay, Qa, and QTa in Slate et al., 1999) (Figure 1-4; Plate 1 and Figure 4-3). Although the AA is considered the highest (i.e., youngest) HSU in the model, stratigraphically, it consists of alluvial debris as young as recent alluvium found in active drainages, and as old as tuffaceous gravels that may correlate time-stratigraphically with the volcanic units of the Thirsty Canyon Group, approximately $9 \mathrm{Ma}$ (Sawyer et al., 1994).

The alluvium in Frenchman Flat is a friable to moderately consolidated, poorly sorted mixture of detritus derived from volcanic and Paleozoic-age sedimentary rocks, ranging in particle size from clay to boulders. Sediment deposition is largely in the form of alluvial fans which coalesce to form discontinuous, gradational, and poorly sorted deposits. Eolian sand, basalt lava flows, and playa deposits are also present within the alluvium section. Basalt lava flows and playa deposits have been designated as separate HSUs in the Frenchman Flat base model and are discussed in following subsections.

The alluvial aquifer is an important aquifer in Frenchman Flat because many of the underground nuclear tests were conducted in this unit, and it is thick and extensive within much of the model area (Figure 4-5). Significant saturated thicknesses are present in the central portion of the model area (Profiles B-B' and C-C'). Where saturated, the unit is considered an aquifer, as 
Table 4-4

Hydrostratigraphic Units of the Frenchman Flat Hydrostratigraphic Framework Model

\begin{tabular}{|c|c|c|c|c|}
\hline $\begin{array}{l}\text { Hydrostratigraphic Unit } \\
\text { (Symbol) }\end{array}$ & $\begin{array}{l}\text { Dominant } \\
\text { Hydrogeologic } \\
\text { Unit(s) }^{\mathrm{a}}\end{array}$ & $\begin{array}{l}\text { Stratigraphic } \\
\text { Unit Map } \\
\text { Symbols }\end{array}$ & General Description & $\begin{array}{l}\text { Transport } \\
\text { Parameter } \\
\text { Category }\end{array}$ \\
\hline $\begin{array}{c}\text { alluvial aquifer } \\
\text { (AA, AA3, AA2, AA1) } \\
\text { (this term is also used to } \\
\text { designate a hydrogeologic unit) }\end{array}$ & AA & $\begin{array}{l}\text { Qay, QTc, Qai, } \\
\text { QTa, Tt }\end{array}$ & $\begin{array}{l}\text { Consists mainly of alluvium that fills extensional basins. Also includes } \\
\text { generally older Tertiary gravels and very thin air-fall tuffs. AA, AA1, AA2, } \\
\text { and AA3 are equivalent hydrogeologically except for position relative to } \\
\text { other HSUs embedded within the alluvial section (see Figures } 4-7 \text { and } \\
4-10) \text {. }\end{array}$ & AA \\
\hline $\begin{array}{l}\text { playa confining unit } \\
\text { (PCU2T) }\end{array}$ & PCU & Qp & Clayey silt and sandy silt. Forms the Frenchman Flat playa (dry lake). & TCU \\
\hline $\begin{array}{l}\text { basalt lava-flow aquifer } \\
\text { (BLFA) }\end{array}$ & LFA & Tybf & $\begin{array}{l}\text { Several (possibly dissected) basalt flows are recognized in the middle of } \\
\text { the alluvial section of the northeastern Frenchman Flat. Related to other } \\
\text { basalt flows in Nye Canyon. }\end{array}$ & LFA \\
\hline $\begin{array}{l}\text { older altered alluvial aquifer } \\
\quad(\mathrm{OAA}, \text { and } O A A 1)\end{array}$ & AA & QTa & $\begin{array}{l}\text { Older, denser, zeolitized alluvium recognized only in northern Frenchman } \\
\text { Flat. OAA and OAA1 are equivalent except for position: the OAA is } \\
\text { above the BLFA, and the OAA1 is stratigraphically beneath the BLFA (see } \\
\text { Figure 4-10). }\end{array}$ & $\begin{array}{l}\text { TCU } 50 \% \\
\text { AA } 50 \%\end{array}$ \\
\hline $\begin{array}{l}\text { older playa confining unit } \\
\text { (PCU1U and PCU1L) }\end{array}$ & PCU & QTp & $\begin{array}{l}\text { Deep, subsurface playa deposits in the deepest portion of Frenchman } \\
\text { Flat. Recognized in Well ER-5-4\#2 and with 3-D seismic data. The } \\
\text { PCU1U and PCU1L are similar except for position (see Figure 4-7). }\end{array}$ & TCU \\
\hline $\begin{array}{l}\text { Timber Mountain welded-tuff } \\
\text { aquifer } \\
\text { (TM-WTA) }\end{array}$ & $\begin{array}{l}\text { Mostly WTA, } \\
\text { minor VTA }\end{array}$ & $\begin{array}{l}\text { Tma, Tmab, } \\
\text { Tmr }\end{array}$ & $\begin{array}{l}\text { Consists mainly of welded ash-flow tuffs of Ammonia Tanks Tuff and } \\
\text { Rainier Mesa Tuff. Unit occurs mostly in north and central Frenchman } \\
\text { Flat. Prolific aquifer when saturated. }\end{array}$ & $\begin{array}{l}\text { WTA } 90 \% \\
\text { VTA } 10 \%\end{array}$ \\
\hline $\begin{array}{l}\text { Timber Mountain lower } \\
\text { vitric-tuff aquifer } \\
\text { (TM-LVTA) }\end{array}$ & VTA & $\begin{array}{l}\text { Tma, Tmab, } \\
\text { Tmr, Tmrh, Tp, } \\
\text { Th }\end{array}$ & $\begin{array}{l}\text { Defined to include all unaltered (nonzeolitic) nonwelded and bedded tuffs } \\
\text { below the welded Tmr and above the level of pervasive zeolitization. The } \\
\text { presence of the welded Tpt (see TSA) complicates this general } \\
\text { description. }\end{array}$ & VTA \\
\hline $\begin{array}{l}\text { upper tuff confining unit } \\
\text { (UTCU) }\end{array}$ & TCU & $\begin{array}{l}\text { Tmr (lower } \\
\text { most), Tmrh, } \\
\text { Tp }\end{array}$ & $\begin{array}{l}\text { Relatively thin TCU above the TSA. Grouped with the LTCU where the } \\
\text { TSA is not present. }\end{array}$ & $\begin{array}{l}\text { TCU } 90 \% \\
\text { VTA } 10 \%\end{array}$ \\
\hline $\begin{array}{c}\text { Topopah Spring aquifer } \\
\text { (TSA) }\end{array}$ & WTA & Tpt & $\begin{array}{l}\text { The welded ash-flow lithofacies of the Topopah Spring Tuff in } \\
\text { Massachusetts Mountain / French Peak area and north-central Frenchman } \\
\text { Flat. }\end{array}$ & $\begin{array}{l}\text { WTA } 80 \% \\
\text { VTA } 20 \%\end{array}$ \\
\hline
\end{tabular}


Table 4-4

Hydrostratigraphic Units of the Frenchman Flat Hydrostratigraphic Framework Model (continued)

\begin{tabular}{|c|c|c|c|c|}
\hline $\begin{array}{l}\text { Hydrostratigraphic Unit } \\
\text { (Symbol) }\end{array}$ & $\begin{array}{l}\text { Dominant } \\
\text { Hydrogeologic } \\
\text { Unit(s) }^{\text {a }} \\
\end{array}$ & $\begin{array}{l}\text { Stratigraphic } \\
\text { Unit Map } \\
\text { Symbols } \\
\end{array}$ & General Description & $\begin{array}{l}\text { Transport } \\
\text { Parameter } \\
\text { Category } \\
\end{array}$ \\
\hline $\begin{array}{l}\text { lower vitric-tuff aquifer } \\
\text { (LVTA) }\end{array}$ & VTA & Th & $\begin{array}{l}\text { Relatively thin VTA unit below the TSA. Grouped with the TM-LVTA } \\
\text { where TSA is not present. }\end{array}$ & VTA \\
\hline $\begin{array}{l}\text { lower tuff confining unit } \\
\text { (LTCU and LTCU1) }\end{array}$ & $\begin{array}{l}\text { TCU, } \\
\text { minor WTA }\end{array}$ & $\begin{array}{l}\text { Th, Tw, Tc, Tn, } \\
\text { To }\end{array}$ & $\begin{array}{l}\text { Generally includes all the zeolitic nonwelded and bedded tuffs in } \\
\text { southeastern NTS. May include all units from base of Tmr to top of } \\
\text { Paleozoic-age rocks. The Tw stratigraphic interval grades or interfingers } \\
\text { laterally (westward) into the WCU (see below). Zeolitic bedded tuffs } \\
\text { stratigraphically below the WCU (e.g. Tc, Tn, and To) are classified as the } \\
\text { LTCU1 in order to address the operation requirements of the EarthVision }{ }^{\circledR} \\
\text { modeling software. }\end{array}$ & $\begin{array}{l}\text { TCU } 95 \% \\
\text { WTA } 5 \%\end{array}$ \\
\hline $\begin{array}{l}\text { Wahmonie confining unit } \\
\text { (WCU) }\end{array}$ & TCU, minor LFA & $\begin{array}{l}\text { Tw (Twu, Twm, } \\
\text { Twl, Twls) }\end{array}$ & $\begin{array}{l}\text { Mixture of lava flows, debris flows, lahars, ash-flows, and air-falls. } \\
\text { Typically zeolitic, argillic, or hydrothermally altered. Grades or interfingers } \\
\text { laterally with the LTCU. }\end{array}$ & $\begin{array}{l}\text { TCU } 80 \% \\
\text { AA } 10 \% \\
\text { CA } 5 \%\end{array}$ \\
\hline $\begin{array}{l}\text { volcaniclastic } \\
\text { confining unit } \\
\qquad \text { (VCU) }\end{array}$ & $\begin{array}{l}\text { TCU, minor AA } \\
\text { and CA }\end{array}$ & Tgp, Tgw & $\begin{array}{l}\text { Older Tertiary sedimentary rocks of variable lithologies including silt, clay, } \\
\text { limestone, gravel and tuffaceous units. Present in southeastern half of } \\
\text { Frenchman Flat. }\end{array}$ & $\begin{array}{l}\text { TCU } 85 \% \\
\text { AA } 10 \% \\
\text { CA } 5 \%\end{array}$ \\
\hline $\begin{array}{l}\text { lower carbonate aquifer- } \\
\text { thrust plate } \\
\text { (LCA3) }\end{array}$ & CA & Dg through Cc & $\begin{array}{l}\text { Cambrian through Devonian, mostly limestone and dolomite, rocks that } \\
\text { occur in the hanging wall of the Belted Range thrust fault. Present only in } \\
\text { the northwest corner (CP Basin) of the model area. }\end{array}$ & CA \\
\hline $\begin{array}{l}\text { upper clastic } \\
\text { confining unit } \\
\quad(\text { UCCU) }\end{array}$ & $\mathrm{CCU}$ & Mc, MDe & $\begin{array}{l}\text { Late Devonian through Mississippian siliciclastic rocks. Present only in } \\
\text { the northwest corner (CP Basin) of the model area, northwest of Cane } \\
\text { Spring fault and southwest of Topgallant fault. }\end{array}$ & $\mathrm{CCU}$ \\
\hline $\begin{array}{l}\text { lower carbonate aquifer } \\
\qquad(\text { LCA) }\end{array}$ & CA & Dg through Cc & $\begin{array}{l}\text { Cambrian through Devonian mostly limestone and dolomite. Regional } \\
\text { carbonate aquifer present throughout the model area. }\end{array}$ & CA \\
\hline $\begin{array}{l}\text { lower clastic } \\
\text { confining unit } \\
\quad(\text { LCCU })\end{array}$ & $\mathrm{CCU}$ & $\begin{array}{l}\mathrm{Cc}, \mathrm{Cz}, \mathrm{Czw} \\
\mathrm{Zs}, \mathrm{Zj}\end{array}$ & $\begin{array}{l}\text { Late Proterozoic through Early Cambrian siliciclastic rocks. Hydrologic } \\
\text { "basement" present at great depth in the model area. }\end{array}$ & $\mathrm{CCU}$ \\
\hline
\end{tabular}

a See Table 4-3 for definitions of HGUs.

b See Tables 4-1 and 4-2 for definitions of stratigraphic unit map symbols.

c These subdivisions are equivalent hydrogeologically but are necessary to satisfy operational requirements of the EarthVision ${ }^{\circledR}$ Software.

d Indicator of HSU hydraulic properties, provided for flow-and-transport modelers. 
Table 4-5

Correlation of Hydrostratigraphic Units of the Frenchman Flat Model and Earlier Models

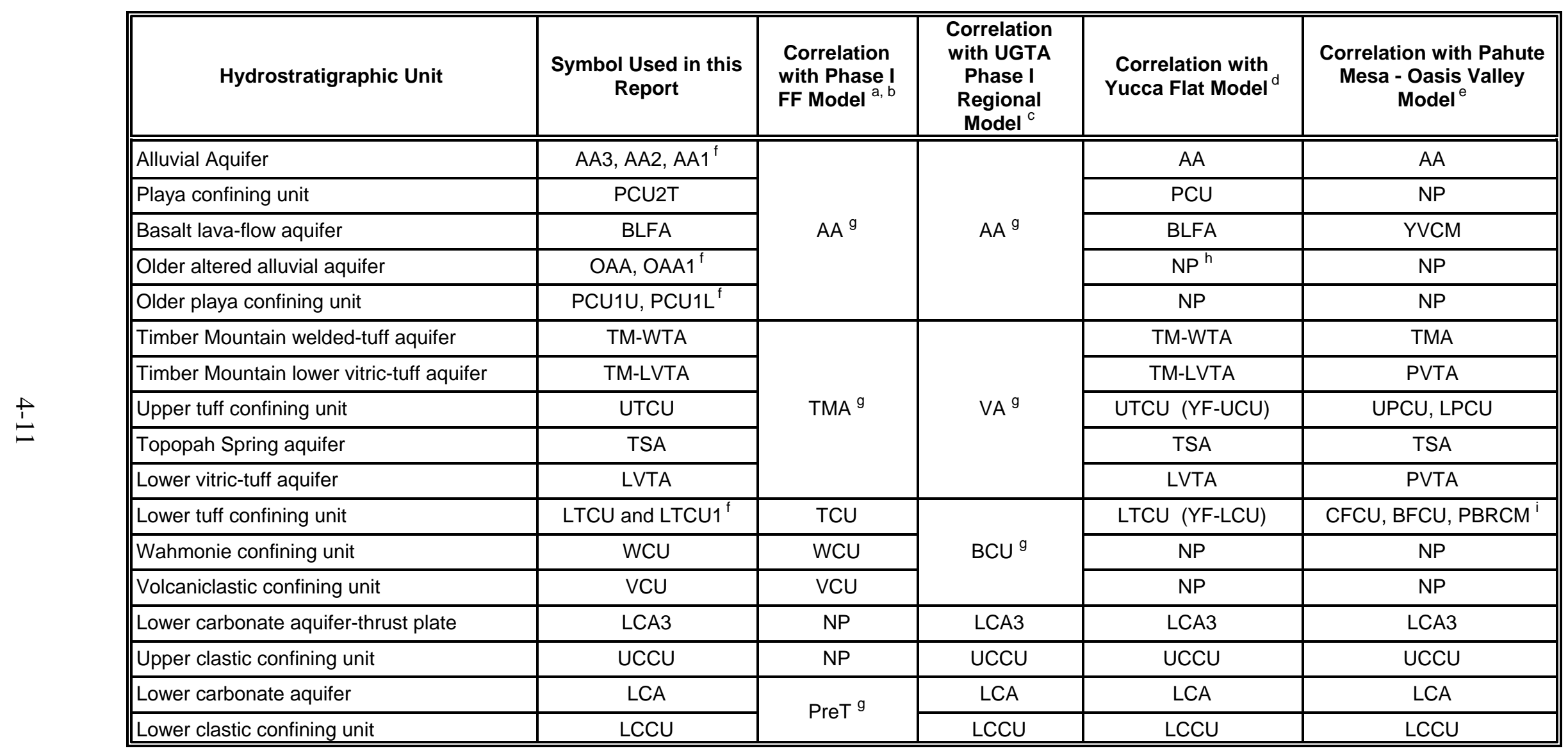

a If correlative to more than one HSU, all HSUs are listed.

b See IT, 1998 for explanation initial FF model (1998) nomenclature.

c See IT (1996a) for explanation of the UGTA Phase I HSU nomenclature.

d Preparation of documentation material for final Yucca Flat model is in progress. See Gonzales et al. (1998) for explanation of the Yucca Flat HSU nomenclature.

e See BN, 2002 for explanation of Pahute Mesa/Oasis Valley HSU nomenclature.

f Subdivisions, though hydrogeologically equivalent, are necessary to satisfy operational requirements of the EarthVision ${ }^{\circledR}$ modeling software.

g Not subdivided.

h Not present.

i PBRCM may include embedded ash-flow tuffs. 
inferred from high hydraulic conductivity and specific capacity values from NTS wells completed within the AA (e.g., Water Wells 5a, 5b, and 5c in Frenchman Flat [Classen, 1973; IT, 1996b]; Well A, Well 3 [IT, 1996b]). However, the more tuffaceous intervals may have zeolitic alteration that could locally reduce the unit's ability to transmit water. The AA is over 1,220 m (4,000 ft) thick in the vicinity of Well Cluster ER-5-4 (DOE, 2005b) located near the central portion of the valley.

Lithologic and physical properties data from drill holes near the Area 5 RWMS indicate that the alluvium is relatively homogenous (REECo, 1993a, 1993b; BN, 2005). Hydrologic data show that the alluvium is isotropic with respect to hydrologic properties as well (Sully et al., 1993). Thus, no subdivisions of the alluvial aquifer were included in the initial Phase I hydrogeologic model for Frenchman Flat (IT, 1998). Pawloski (1996) also concluded that the limited data available suggested that Frenchman Flat alluvium is homogeneous on a basin-wide scale. However, she recommended that during the modeling process this unit should be tested to determine if the localized zones of dense alluvium identified in northern Frenchman Flat have any influence on groundwater flow. As more information became available as a result of Phase II data acquisition, subdividing the alluvium became possible. These subdivisions, particularly the older altered alluvium, are discussed separately in the following subsections.

The AA is subdivided into three EarthVision ${ }^{\circledR}$ model layers: AA1, AA2, and AA3. These subdivsions are equivalent hydrogeologically except for position relative to other HSUs imbedded within the alluvial section. Such subdivisions are necessary to satisfy operational requirements of the of the EarthVision ${ }^{\circledR}$ software, only, and do not represent geologically significant boundaries.

\subsubsection{Playa Confining Unit (PCU2T, PCU1U, and PCU1L)}

Three separate playa confining units are defined in the Frenchman Flat model: a younger unit that includes the youngest deposits at the surface (PCU2T) and two older, buried units (PCU1U and PCU1L). The playa deposits are mainly clayey silt, but may also contain intercalated beds of sand and pumice. The playa deposits behave as an aquitard due to the abundance of silt and clay (Winograd and Thordarson, 1975).

Frenchman Lake is a prominent playa near the center of Frenchman Flat. The playa deposits that compose the Frenchman Lake playa are designated PCU2T in the hydrostratigraphic framework model (Figure 4-6). The PCU2T is approximately $150 \mathrm{~m}$ (500 ft) thick. The relationship of the PCU2T to the older playa confining units (i.e., PCU1U and PCU1L) with the alluvial aquifer is shown in Figure 4-7. 
Beneath the central portion of Frenchman Flat, two zones of low reflectivity within the alluvium section are observed in the 3-D seismic data (see Appendix D). The upper of these two zones is penetrated by Well ER-5-4\#2 where it corresponds to fine-grained sand, silt, and clay that is interpreted to represent an earlier period of playa deposition. The lower zone is not penetrated by any drill holes, and is define strictly on a similar seismic character to the upper zone. This lower zone is also interpreted to represent older playa deposits.

The buried playa deposits are designated hydrostratigraphically as older playa confining units due to the fine-grained nature of playa deposits. Because the two deposits are separated by coarser alluvium, they are designated as separate EarthVision ${ }^{\circledR}$ layers in the framework model. The upper of the two older playa confining units is designated PCU1U, and its extent is shown in Figure 4-8. The lower older playa confining unit is designated PCU1L, and its extent is shown in Figure 4-9. The hydraulic characteristics of both the PCU1U and PCU1L are assumed to be similar to the modern playa deposit (PCU2T) that is exposed at Frenchman Lake.

\subsubsection{Older Alluvial Aquifer (OAA and OAA1)}

Pawloski (1996) conducted an investigation using existing literature, lithologic logs, and geophysical data to determine if these deposits could be subdivided on the basis of hydrogeologic characteristics, as described in Section 2.3.6.1. One of the units she examined was a dense alluvium recognized by Carr et al. (1975), Miller and Healey (1986), and others, which might possess hydrologic properties that are slightly different from those of the rest of the alluvial section. Although Pawloski (1996) confirmed that this subunit can be distinguished on the basis of bulk density, porosity, and velocity, she found that it apparently is discontinuous and of local extent, having been identified in only a few drill holes in northern Frenchman Flat.

Analysis of recent XRD data from Well Cluster ER-5-3 has shown that this “older, denser” alluvium has undergone low-grade zeolitic alteration (DOE, 2005a). The original vitric constituents in the alluvial matrix have been altered to the zeolite clinoptilolite. Such alteration has a tendency to lower overall hydraulic conductivity of the formation. This assumption is substantiated by the lower than expected water production while drilling this interval at Well Cluster ER-5-3. The distribution of the older alluvium aquifer (OAA) is shown in Figure 4-6. The distribution of the older alluvium aquifer 1 (OAA1) is shown in Figure 4-9.

The OAA1, which occurs below the basalt lava-flow aquifer, and the OAA, which is above the BLFA, are hydrogeologically equivalent (Figure 4-10). It was necessary to subdivide them to satisfy operational requirements of the EarthVision ${ }^{\circledR}$ modeling software, only, and does not represent a geologically significant boundary. 


\subsubsection{Basalt Lava-Flow Aquifer (BLFA)}

Basalt was encountered within the alluvial section beneath the northern portion of Frenchman Flat in drill holes UE-5i (Dixon et al., 1967), UE-5k (Byers and Miller, 1966), and at Well

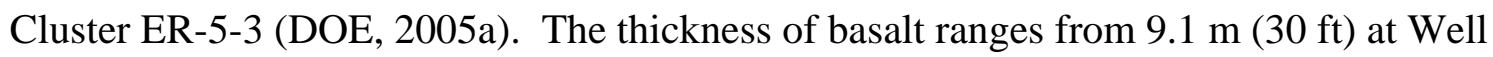
Cluster ER-5-3 to $25.9 \mathrm{~m}$ (85 ft) at UE-5i. The depth to the basalt ranges from $268.2 \mathrm{~m}(880 \mathrm{ft}$ ) at UE-5i to $289.6 \mathrm{~m}$ (950 ft) at UE-5k, which places the basalt near the water table, particularly at Well Cluster ER-5-3 and UE-5k (Figure 4-11). Ages of the basalt in UE-5i (8.6 Ma) and UE-5k (8.4 Ma) are similar (RSN, 1994). Surface magnetic data appear to show that the basalt is not a single continuous flow, but instead occurs as three separate and isolated flows (Carr et. al, 1975).

Because dense volcanic rocks like basalt tend to be highly fractured at the NTS, the basalt beneath northern Frenchman Flat likely has hydraulic properties considerably different than that of the encasing alluvium. Therefore, the basalt was modeled as a separate HSU called the basalt lava-flow aquifer (BLFA). This HSU includes all three of the basalt occurrences beneath northern Frenchman Flat. Figure 4-8 shows the distribution of the BLFA; the relationship of the BLFA to the various alluvial aquifers is shown in Figure 4-10.

Due to uncertainty related to the exact extent of the BLFA and to the potential hydrologic significance of its position near the water table, an alternative model was developed that includes a more extensive and continuous occurrence of BLFA. This alternative model is described in more detail in Section 5.2.

\subsubsection{Timber Mountain Hydrostratigraphic Units}

The Timber Mountain HSUs include, stratigraphically, the Rainier Mesa Tuff and younger Ammonia Tanks Tuff, both formations of the Timber Mountain Group (Figure 4-2).

Lithologically, the Timber Mountain HSUs consist mostly of welded ash-flow tuff and lesser amounts of vitric (i.e., unaltered) nonwelded ash-flow tuff and bedded tuff. These rocks were erupted from the Rainier Mesa and Ammonia Tanks calderas, and deposited as outflow sheets and ash-fall deposits in areas outside of the margins of the calderas.

The unaltered volcanic rocks of the Frenchman Flat model area are divided into two Timber Mountain HSUs. The hydrology of this part of the geologic section is complicated by the presence of one or more ash-flow tuffs units that are quite variable in properties both vertically and laterally. The Timber Mountain Group includes ash-flow tuffs that can be either welded-tuff aquifers or vitric-tuff aquifers, depending on the degree of welding. Where the Rainier Mesa Tuff is less than about $76 \mathrm{~m}(250 \mathrm{ft})$ thick the formation is typically poorly welded, and the 
entire unit is classified as the Timber Mountain lower vitric-tuff aquifer (TM-LVTA). In locations where the Rainier Mesa Tuff is more than $76 \mathrm{~m} \mathrm{(250} \mathrm{ft)} \mathrm{thick,} \mathrm{all} \mathrm{but} \mathrm{the} \mathrm{bottom} 30 \mathrm{~m}$ $(100 \mathrm{ft})$ is classified as the Timber Mountain welded-tuff aquifer (TM-WTA), and the bottom $30 \mathrm{~m}$ (100 ft) of nonwelded ash-flow tuff is generally included in the TM-LVTA. The overlying Ammonia Tanks Tuff is included with the TM-WTA when either the Ammonia Tanks Tuff or Rainier Mesa Tuff is sufficiently thick to be welded. Otherwise, the Ammonia Tanks Tuff is considered to be a vitric-tuff aquifer, and is included in the TM-LVTA. The relationship of these HSUs is depicted in Figure 4-12.

The thicknesses of the TM-WTA and TM-LVTA in the north-central portion of the model area are well constrained where they are extensively exposed and numerous drill holes penetrate them. In this area the volcanic aquifers are approximately $260 \mathrm{~m}$ (850 ft) thick. West and east of this data corridor, the thickness of the HSUs is poorly constrained due to burial by thick alluvium and absence of drill hole penetrations. At Well Cluster ER-5-4, more than $196 \mathrm{~m}$ (644 ft) of the TM-WTA was encountered (DOE, 2005b).

The designation of these units as aquifers is based on the predominance of densely welded tuff (which is assumed to be fractured and transmissive) and vitric, nonwelded and bedded tuff. This designation is consistent with water production data from Well ER-5-3, where the TM-WTA produced 1,893 liters per minute (lpm) (500 gallons per minute [gpm]) of water during drilling of welded Ammonia Tanks Tuff (DOE, 2005a), and up to 10,220 lpm (2,700 gpm) near the bottom of the welded Rainier Mesa Tuff. Note that this water production was during air-foam drilling, and the formation was reported to be highly fractured. Additional hydrologic data for outflow sheets of welded Ammonia Tanks and Rainier Mesa Tuff outside of the model area in the vicinity of Yucca Flat indicate these units are significant aquifers where saturated (IT, 1996c).

\subsubsection{Timber Mountain Welded-Tuff Aquifer (TM-WTA)}

The TM-WTA is not an extensive HSU, being generally confined to the north-central and northwestern portions of the model area, and west of the basin-forming faults. Additionally, in Frenchman Flat the Ammonia Tanks and Rainier Mesa Tuffs are saturated only in the deeper portions of the basin. The distribution of the TM-WTA is shown in Figure 4-13, and its relationship to other volcanic HSUs is shown in Figure 4-14. Figure 4-15 shows the depth below ground surface of the top of the HSU.

The extent of the TM-WTA is not well constrained (Figure 4-13). The unit occurs north and south of the Well Clusters ER-5-3 and ER-5-4. Extensive outcrops and numerous drill-hole 
penetrations in northern Frenchman Flat provide unambiguous evidence that the HSU is extensive in the northern portion of the model area, north of Well Cluster ER-5-4. The presence of more than $198 \mathrm{~m}$ (650 ft) of TM-WTA at Well Cluster ER-5-3 (DOE, 2005a) indicates that the HSU is an important aquifer within the northern portion of the valley.

\subsubsection{Timber Mountain Lower Vitric-Tuff Aquifer (TM-LVTA)}

The TM-LVTA includes all unaltered bedded, ash-fall, reworked tuff, and nonwelded ash-flow tuff units present above the level of pervasive zeolitization in Frenchman and Yucca Flats. However, where welded Topopah Spring Tuff, which forms the Topopah Spring aquifer (TSA), is present, unaltered nonwelded tuffs below the TSA are grouped within a separate HSU called the lower vitric tuff aquifer (LVTA). Welded tuffs are included in the TM-WTA (described in Section 4.4.5.1). Stratigraphically, the TM-LVTA typically includes formations and members of the Timber Mountain and Paintbrush Group, but may also include units within the Calico Hills Formation, and Wahmonie Formation. Older units are generally zeolitized, and are therefore categorized as confining units and placed with the LTCU.

The TM-LVTA has a slightly larger distribution than the TM-WTA. Some TM-LVTA rocks are present beneath the alluvium throughout most of the northern and central portions of Frenchman Flat, though this unit is absent in areas where it has been removed by erosion over major structural highs. These include the western (Wahmonie Hills area) and eastern portions of Frenchman Flat. The TM-LVTA is also absent from portions of northern Frenchman Flat where stratigraphically equivalent rocks are zeolitic, and classified as a separate HSU called the upper tuff confining unit (UTCU; Section 4.4.6). The distribution of the TM-LVTA is shown in Figure 4-16, and its relationship with other volcanic HSUs is shown in Figure 4-14. The depth to the top of the TM-LVTA is shown in Figure 4-17.

In Frenchman Flat the TM-LVTA units are saturated in the deep central portion of the basin. The TM-LVTA exhibits significant interstitial porosity, ranging from about 20 to 40 percent. However, because these lithologies tend to be poorly to moderately indurated, fractures are not common. So, even though interstitial porosity may be high, transmissivities are not great.

\subsubsection{Upper Tuff Confining Unit (UTCU)}

The zeolitized nonwelded tuffs that overlie the Topopah Spring Tuff in north-central Frenchman Flat are designated as the upper tuff confining unit (UTCU). Stratigraphically, the UTCU includes units from the base of the welded Rainier Mesa Tuff to the top of welded Topopah Spring Tuff. The areal extent of the UTCU is limited in Frenchman Flat, where it occurs only beneath the northern portion of the basin. The extent of this HSU is not well constrained, but it 
appears to overlie the area of detachment faulting, and thus may be related to this feature. The unit is not present in Well ER-5-4\#2 due to stratigraphically equivalent rocks being unaltered, and thus assigned to the TM-LVTA. The UTCU is also absent from the hills north of Frenchman Flat, where equivalent rocks are also unaltered, and assigned to the TM-LVTA. Where the TSA (Section 4.4.7) is not present, but zeolitic rocks equivalent to the UTCU are present, the zeolitic rocks are assigned to the lower tuff confining unit (LTCU; Section 4.4.10). The UTCU is also present in the southern portion of the Yucca Flat basin immediately above the TSA. The distribution of the UTCU in the Frenchman Flat model area is shown in Figure 4-18, and its relationship with other volcanic HSUs is shown in Figure 4-14.

The hydrologic properties of the two tuff confining units (the UTCU and the LTCU) are considered to be essentially identical. The UTCU at Well ER-5-3\#2 produced water at a very low rate (DOE, 2005a; see also IT, 2002 and SNJV, 2004a) and behaved as a viable aquitard that separates the overlying TM-WTA from the TSA.

\subsubsection{Topopah Spring Aquifer (TSA)}

The TSA consists of a single welded-tuff aquifer composed of welded ash-flow tuff of the Yucca/Frenchman Flat lobe of the Topopah Spring Tuff (Figure 4-2). The unit is saturated and has a distribution similar to that of the TM-WTA. The relationship of the TSA to the other volcanic HSUs is shown in Figure 4-13.

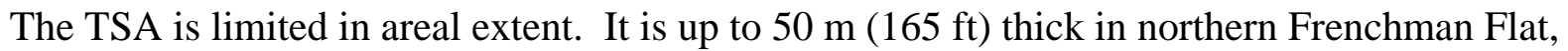
but thins to the north and east in the Halfpint Range, and to the south in Frenchman Flat. The distribution of the TSA is shown in Figure 4-19, and the depth to the top of the unit is shown in Figure 4-20.

The TSA is typically well fractured and therefore highly transmissive. Overall, the hydraulic properties of the TSA are similar to those of the TM-WTA. (Section 4.4.5.1).

\subsubsection{Lower Vitric-Tuff Aquifer (LVTA)}

The LVTA includes all unaltered bedded, ash-fall, reworked tuff, and nonwelded ash-flow tuff units below the TSA and above the level of pervasive zeolitization in Frenchman and Yucca Flats. The LVTA is only differentiated where the TSA is present; these rocks would otherwise be included in the TM-LVTA (Figure 4-2; Section 4.4.5.2). Overlying welded tuffs are included in the TSA welded-tuff aquifer (Section 4.4.7). Stratigraphically, the LVTA may include formations and members of the Paintbrush Group, Calico Hills Formation, Wahmonie 
Formation, Crater Flat Group. Older units are generally zeolitized, and are therefore categorized as confining units and assigned to the LTCU.

The LVTA has a distribution similar to the TSA (Figure 4-19). However, the LVTA is not present beneath portions of northern Frenchman Flat because equivalent units are zeolitic and thus assigned to the LTCU. The distribution of the LVTA is shown in Figure 4-21, and the depth to the top of the unit is shown in Figure 4-22.

In Frenchman Flat the LVTA units are saturated in the deep central portion of the basin. The LVTA exhibits significant interstitial porosity, ranging from about 20 to 40 percent. However, because these lithologies tend to be poorly to moderately indurated, fractures are not common. So, even though interstitial porosity may be high, transmissivities are not great.

\subsubsection{Wahmonie Confining Unit (WCU)}

One of the unique aspects of the Frenchman Flat model area is its proximity to the Wahmonie volcanic center. The highlands associated with this volcanic center form the western boundary of the Frenchman Flat physiographic basin. The Wahmonie Formation, including the Salyer Member, consists mainly of rhyodacitic and dacitic lava flows, flow breccia, ash-flow tuff, ashfall tuff, and reworked tuff (Poole et al., 1965). The lava and breccia flows are interpreted to be restricted in areal extent, but the ash-flow and ash-fall tuffs likely have a much wider distribution. Lavas and flow breccia are probably more abundant in the western third of Frenchman Flat, whereas ash-fall and reworked tuffs are likely the primary Wahmonie units found in the central and eastern parts of the basin (Warren, 1995).

As with the overlying and underlying bedded tuffs, the Wahmonie nonwelded tuff units tend to become zeolitized where saturated, and thus behave hydrologically as a confining unit. Closer to the volcanic source, the rocks are argillized due to hydrothermal alteration (Warren, 1995) and thus are not hydraulically conductive. However, some of the lava flows may remain vitric to devitrified, and thus be transmissive. Evidence for perched and/or semiperched water within these units along the westernmost portion of Frenchman Flat has been presented by several authors (West and Garber, 1961; Carroll, 1963; Poole et al., 1963; Healey et al., 1967;

Carr et al., 1975).

The Wahmonie Formation is divided into two HSUs based on distance from its source area. Wahmonie rocks in the central and eastern parts of the basin (east of Water Well UE-5c) are included within the LTCU (Section 4.4.10). West of Well UE-5c (closer to the Wahmonie center), the heterogenous group of Wahmonie rocks is classified as a "leaky" confining unit and 
designated as the Wahmonie confining unit (WCU). The distribution of the WCU is shown on Figure 4-23. The boundaries of the WCU are very poorly constrained, and thus are conceptual in nature. The relationship of the WCU to other HSUs is shown in Figure 4-24.

\subsubsection{Lower Tuff Confining Unit (LTCU)}

The LTCU is an important hydrogeologic layer over much of the NTS because it separates the volcanic aquifer units from the underlying regional lower carbonate aquifer (LCA). Almost all zeolitized tuff units in Yucca and Frenchman Flat are grouped within the LTCU, which comprises mainly zeolitized nonwelded tuff. In the lower part of the section several zeolitized and devitrified nonwelded to partially welded ash-flow tuff units such as Bullfrog Tuff, Yucca Flat Tuff, and Redrock Valley Tuff, are also included. Stratigraphically, the LTCU may include all the Tertiary volcanic strata from the top of the Paleozoic rocks to the base of the Rainier Mesa Tuff (Figure 4-2). The strongly argillized older tuff and paleocolluvium that directly overlie the Paleozoic rocks in some places are also included. However, the older Tertiary sedimentary rocks in southern Frenchman Flat, and the Wahmonie Formation in the western Frenchman Flat are not included in the LTCU. These two units are differentiated as separate HSUs and are described separately (Sections 4.4.9 and 4.4.11).

The zeolitic bedded tuffs stratigraphically beneath the WCU in the western portion of the Frenchman Flat model are labeled LTCU1 (Figure 4-24). This subdivision was necessary to address operational requirements of the EarthVision ${ }^{\circledR}$ modeling software. The relationship of the LTCU to other volcanic HSUs is shown in Figure 4-14. The LTCU and the LTCU1 are hydrogeologically equivalent except for their position relative to the WCU.

The LTCU is generally present in the northern and western two-thirds of the model area. It is absent over the major structural highs, where the volcanic rocks have been removed by erosion. Areas where the LTCU is absent include the "Paleozoic bench" south of the Rock Valley fault in southern Frenchman Flat, and east of the main basin-forming faults in eastern Frenchman Flat. The distribution of the LTCU is shown in Figure 4-25.

The LTCU is saturated in much of Frenchman Flat, however, measured transmissivities are very low. 


\subsubsection{Volcaniclastic Confining Unit (VCU)}

The Tertiary sedimentary rocks that are exposed south and southwest of Frenchman Flat are divided into two formations: Rocks of Winapi Wash (Yount, 1996) and the younger, more extensive, Rocks of Pavits Spring (Prothro and Drellack, 1997) (Figure 4-2). These units consist of a diverse assemblage of interbedded volcanic and sedimentary rocks deposited primarily in lacustrine and fluvial environments. Specific lithologies include ash-flow tuff, ash-fall tuff, and reworked tuff; shale; tuffaceous sandstone and argillaceous sandstone; siltstone and mudstone; conglomerate; and lesser limestone (Hinrichs, 1968; Barnes et al., 1982). The Tertiary sedimentary rocks are probably present beneath most of southern and central Frenchman Flat, but pinch out in the northern portion of the basin.

The Tertiary sedimentary rocks as a whole are believed to behave as a confining unit because of their tuffaceous component, which has a tendency to become zeolitized below the water table, and the abundance of fine-grained clastic rocks (Prothro and Drellack, 1997). However, the presence of rocks that tend to act as aquifers such as limestone and coarser clastic rocks, might justify their classification as a "leaky" confining unit. Winograd and Thordarson (1975) included these rocks with their "tuff aquitard." For the UGTA Frenchman Flat model, the Tertiary sedimentary rocks are grouped into a distinct HSU, the VCU. The VCU potentially is a significant HSU in southern Frenchman Flat because of its intervening position between overlying saturated rocks and the LCA. The distribution of the VCU is shown in Figure 4-26.

\subsubsection{Lower Carbonate Aquifer - Thrust Plate (LCA3)}

Cambrian-age through Devonian-age, mostly carbonate, rocks that form the hanging wall of the CP thrust fault are assigned to the LCA3. Deformation related to the west-vergent CP thrust fault has placed these older LCA rocks over younger rocks of the UCCU, and over stratigraphically equivalent LCA rocks. Thus, the rocks of LCA3 are stratigraphically equivalent, and probably hydrogeologically similar to the LCA, but are structurally separated from the LCA by the thrust fault (Section 3.2.1; Profiles A-A' and D-D'). The position of these rocks above the UCCU requires that they be distinguishable in the model from the regional aquifer (LCA). The interpreted extent of the LCA3 in the Frenchman Flat model area is shown in Figure 4-27. The depth to the top of the LCA3 is shown in Figure 4-28.

Subsurface control for the LCA3 is poor and no drill holes penetrate this HSU or the CP thrust fault. Remnants of this thrust plate are mapped just outside of the model area in CP Hills northnorthwest of CP Basin. An alternate interpretation was provided for the CP thrust fault and the LCA3 (Section 5.5). 


\subsubsection{Upper Clastic Confining Unit (UCCU)}

Upper Devonian-age and Mississippian-age siliciclastic rocks in the NTS vicinity are assigned to the Eleana Formation and the Chainman Shale (Cashman and Trexler, 1991, 1994; Trexler et al., 1996). The Eleana Formation as originally defined by Poole et al. (1961) was partitioned by Cashman and Trexler (1991) on the basis of lithofacies variations and sediment source. The shaley lithofacies in the Frenchman Flat model area are now grouped in the Chainman Shale, while the section farther east, bearing the non-shaley quartzite, sandstone, and conglomeratic lithofacies, retains the original formation name. The Mississippian and Devonian Eleana Formation and the Mississippian Chainman Shale form the UCCU (Figure 4-2), the extent of which is shown on Figure 4-29. The subsurface control for this HSU is also poor, with no drill hole penetration within the model area. The UCCU crops out just northwest of the model area, in the CP Hills (Plate 1; Figure 4-3). The Frenchman Flat model depicts the UCCU as present only in CP Basin. It is bounded by the Cane Spring fault on the southeast and by the southern extent of the Topgallant fault on the northeast. The subsurface configuration of this unit and its relation to proximal HSUs are depicted in Profiles A-A' and D-D'.

\subsubsection{Lower Carbonate Aquifer (LCA)}

The LCA consists of thick sequences of Middle Cambrian-age through Upper Devonian-age carbonate rocks (Figure 4-2). This HSU serves as the regional aquifer for most of southern Nevada, and locally may be as thick as 5,000 m (16,400 ft) (Winograd and Thordarson, 1975; Cole, 1992). The unit consists mostly of dolomite and interbedded limestone but contains thin shale, quartzite, and calcareous clastic units (Burchfiel, 1964). The LCA outcrops mainly within the southeast portion of the Frenchman Flat model. There are also small exposures of carbonate rocks in the northeastern corner of the model (Figure 4-3 and Plate 1). The extent of this unit is shown in Figure 4-30. The depth to the top of the LCA is shown in Figure 4-31.

Transmissivities of LCA rocks differ from place to place, apparently reflecting the observed differences in fracture and fault densities and characteristics (Winograd and Thordarson, 1975).

\subsubsection{Lower Clastic Confining Unit (LCCU)}

Proterozoic-age to Middle Cambrian-age rocks in the NTS region are largely quartzite and silicacemented siltstone. This section includes the Johnnie Formation, Stirling Quartzite, Wood Canyon Formation, Zabriskie Quartzite, and the lower half of the Carrara Formation (Winograd and Thordarson, 1975). These units make up the LCCU, which is considered to be the regional hydrologic basement (Winograd and Thordarson, 1975; Laczniak et al., 1996; IT, 1996a). The base of the Frenchman Flat model terminates within the LCCU. The composite thickness of the LCCU is about 2,870 m (9,400 ft). Although these rocks are brittle and commonly fractured, 
secondary mineralization seems to have greatly reduced formation permeability (Winograd and Thordarson, 1975). Where it is in a structurally high position, the LCCU may act as a barrier to deep regional groundwater flow. The present structural interpretation for the Frenchman Flat model depicts the LCCU at great depth (Profile C-C'). The interpreted extent of the LCCU in the Frenchman Flat model area is shown in Figure 4-32.

\subsection{Relationship of Hydrostratigraphic Units and the Water Table}

The EarthVision ${ }^{\circledR}$ base framework model was electronically "sliced" along a surface that represents the water table (IT, 1996a) to reveal the distribution of HSUs at the water table (Figure 4-33). Within much of the model area where LCA is structurally high, such as in the northern, eastern, and southern portions, the water table is within the LCA. West of Frenchman Flat the water table is within the WCU, which is exposed at the surface in the Wahmonie Hills along the western margin of the model area. Within much of the Frenchman Flat basin, the water table is within the AA, however, in northern Frenchman Flat beneath the northern testing area, the water table is below the AA and within the OAA, BLFA, and TM-WTA. The water table occurs within volcanic HSUs below the AA in Yucca Flat and most of CP Basin. 


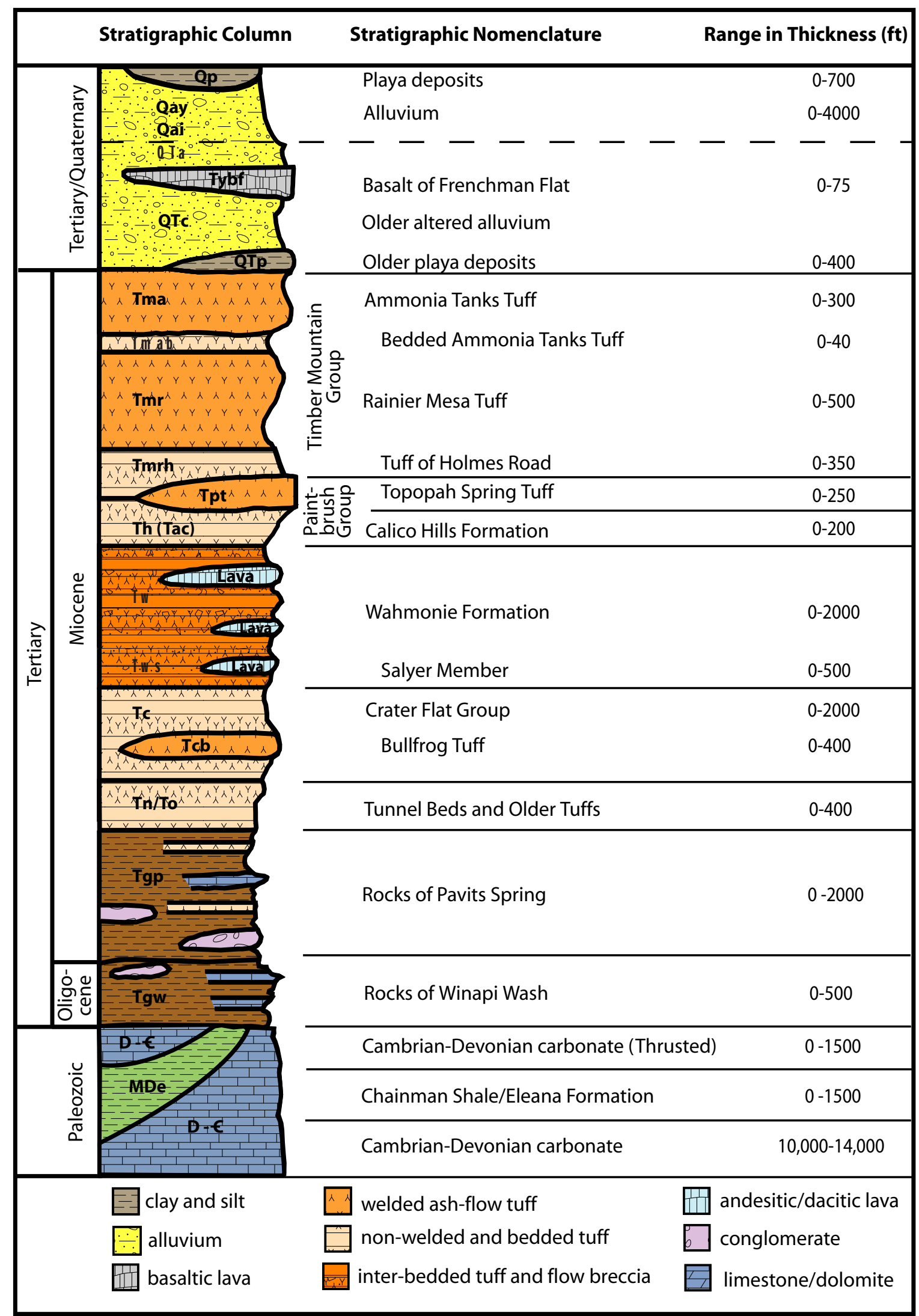

Figure 4-1

Simplified Stratigraphic Section for Frenchman Flat 


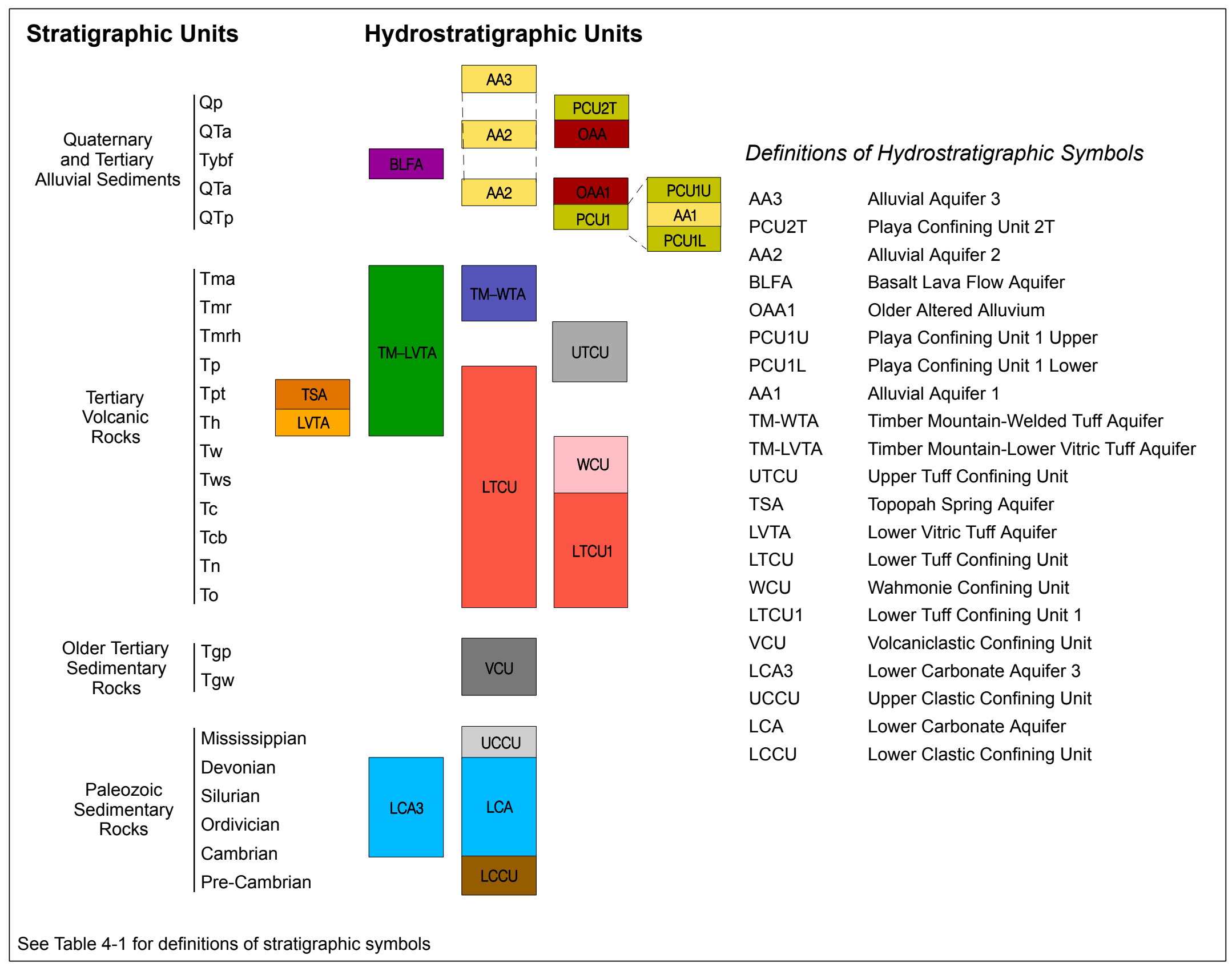

Figure 4-2

Correlation of Stratigraphic and Hydrostratigraphic Units of the Frenchman Flat Model Area 


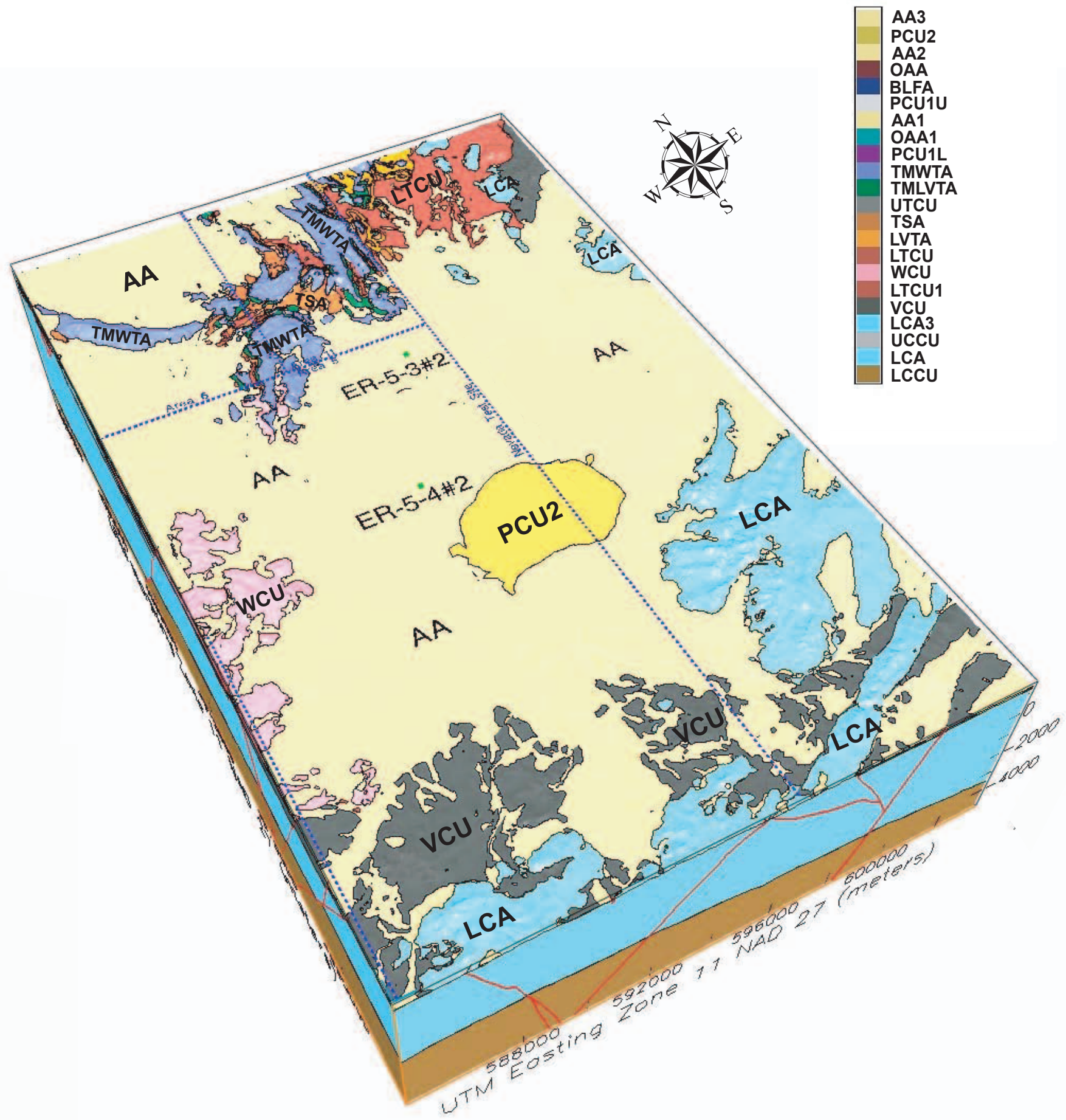

Figure 4-3

Block Model View Showing Hydrostratigraphic Units at the Surface within the Frenchman Flat Model Area 
Hydrostratigraphic Units

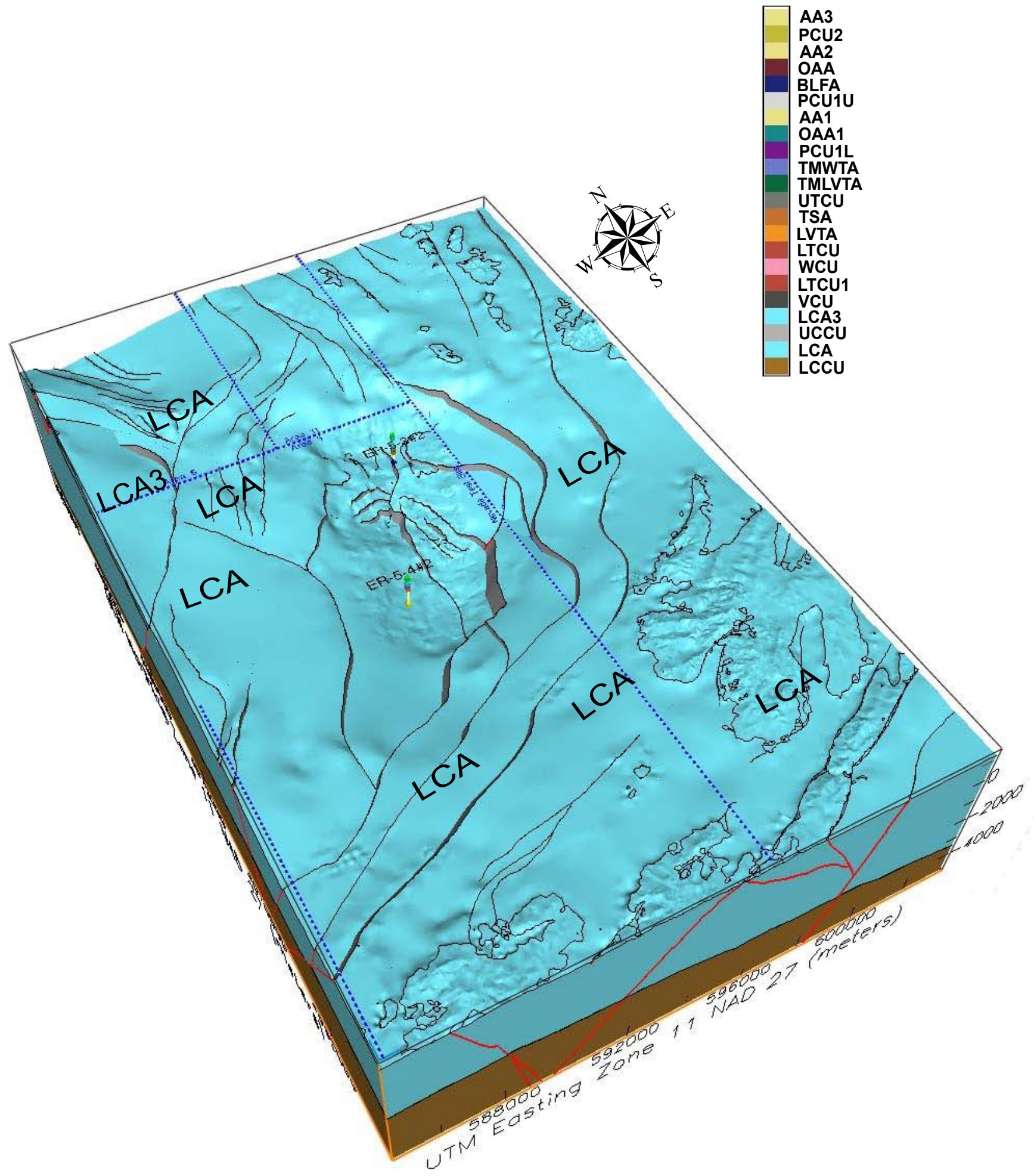

Figure 4-4

Block Model View Showing Basement Subcrop for the Frenchman Flat Model Area 


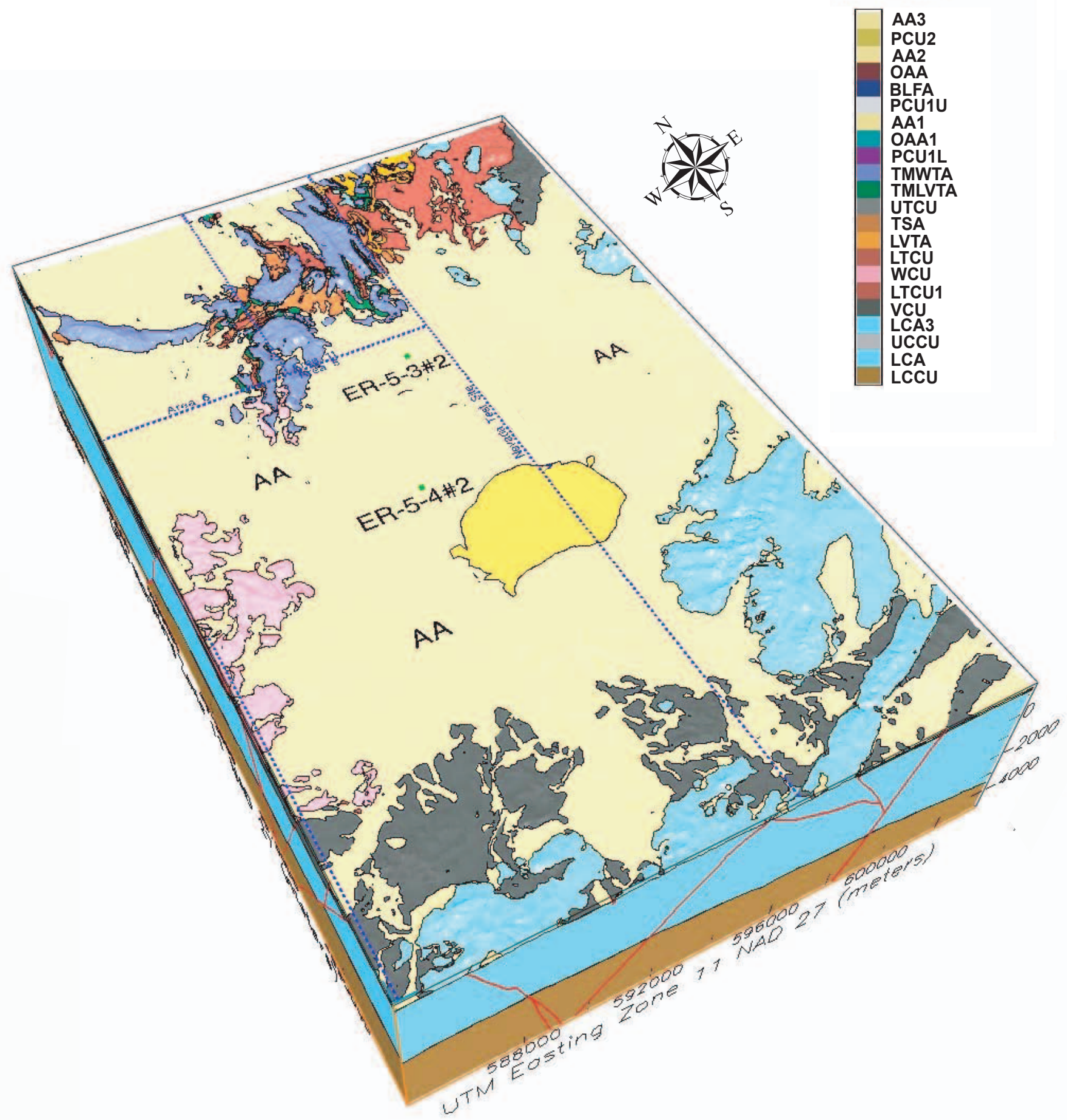

Figure 4-5

Block Model View Showing Extent of the Alluvial Aquifer (AA) within the Frenchman Flat Model Area 


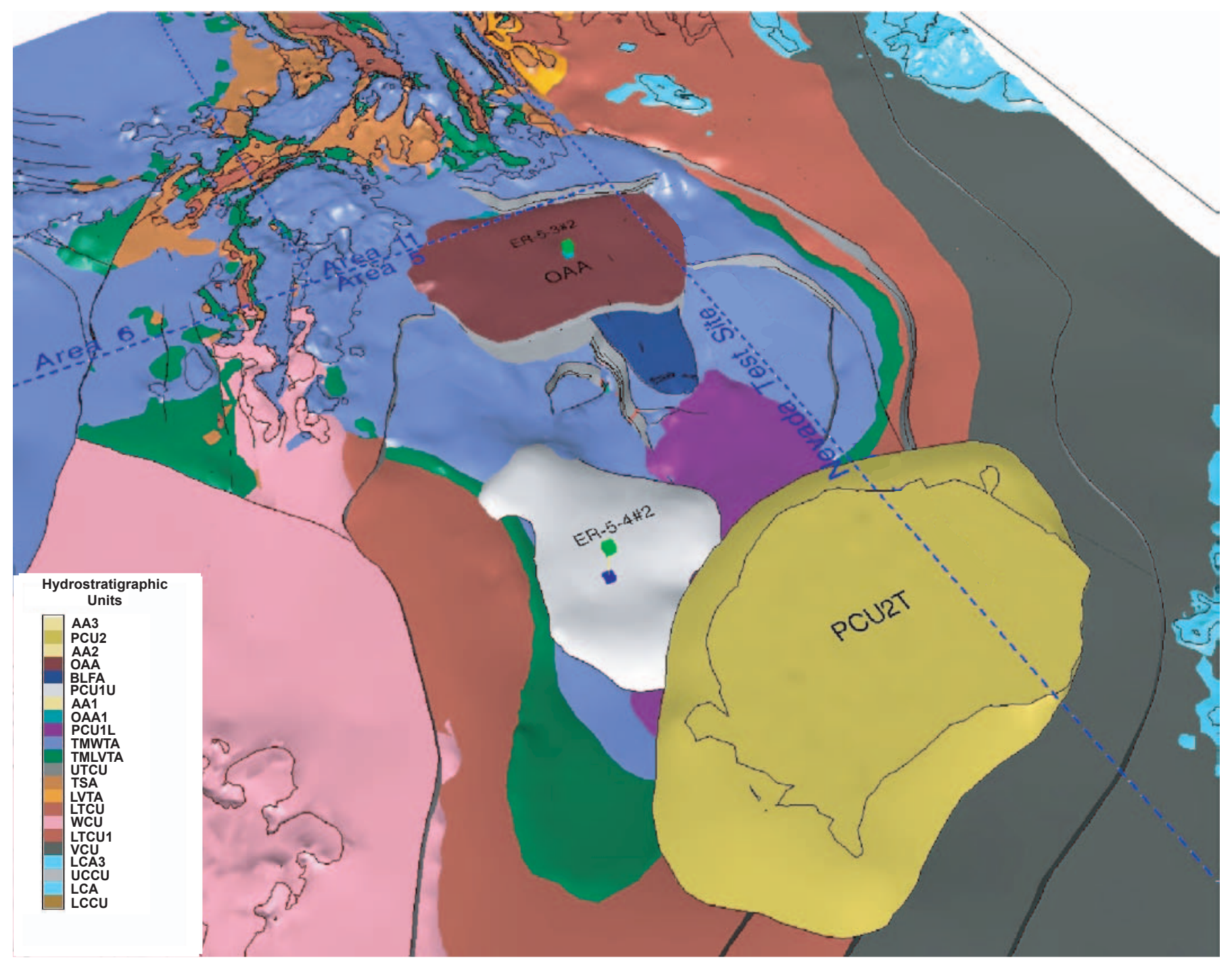

Figure 4-6

Perspective View Showing Extent of the Playa Confining Unit (PCU2T) and the Older Alluvial Aquifer (OAA) within the Frenchman Flat Model Area 


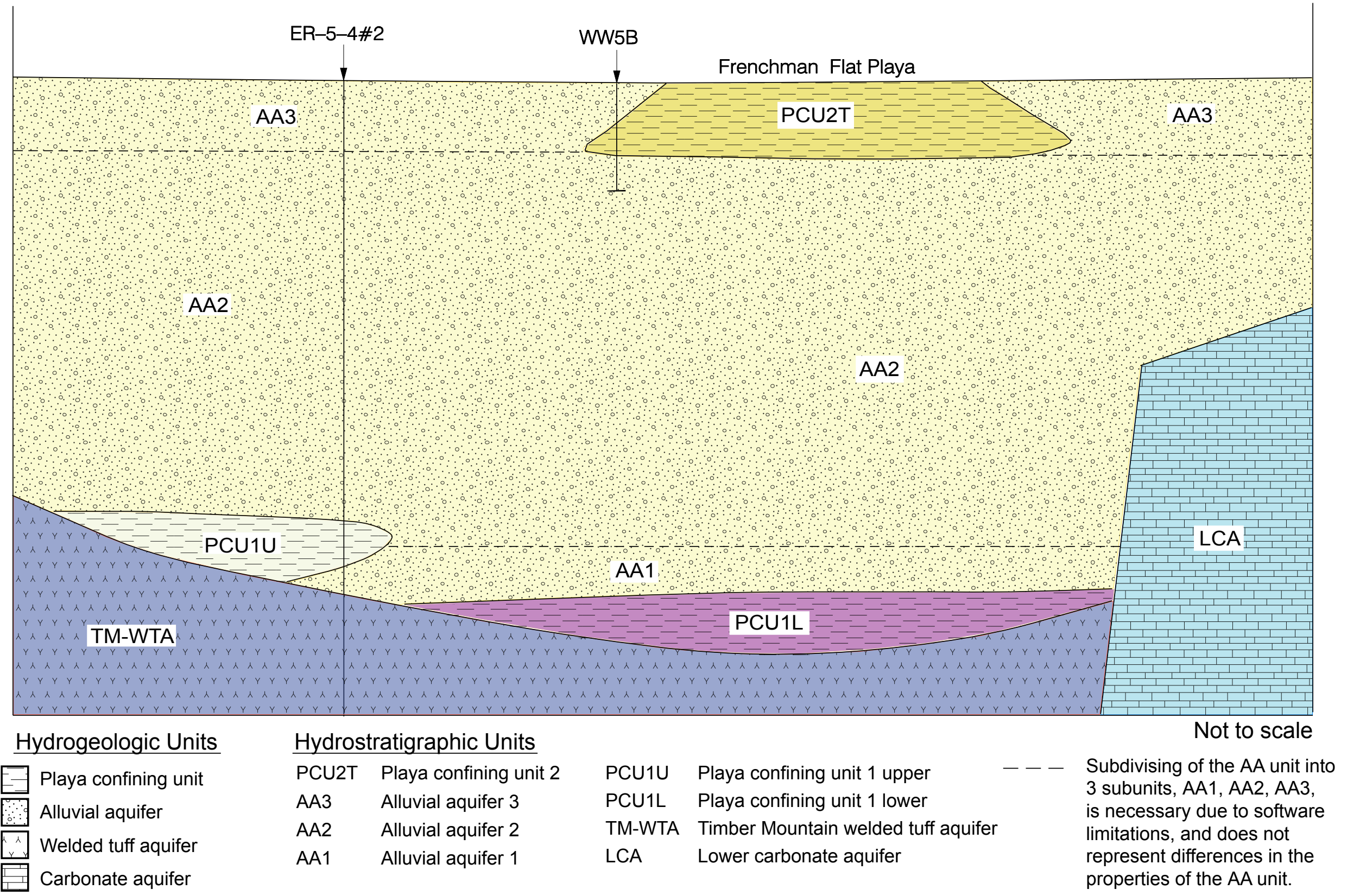

Figure 4-7

Schematic West-East Hydrostratigraphic Cross Section Through Central Frenchman Flat Showing Relationships of the Playa Confining Units and the Alluvial Aquifers. 


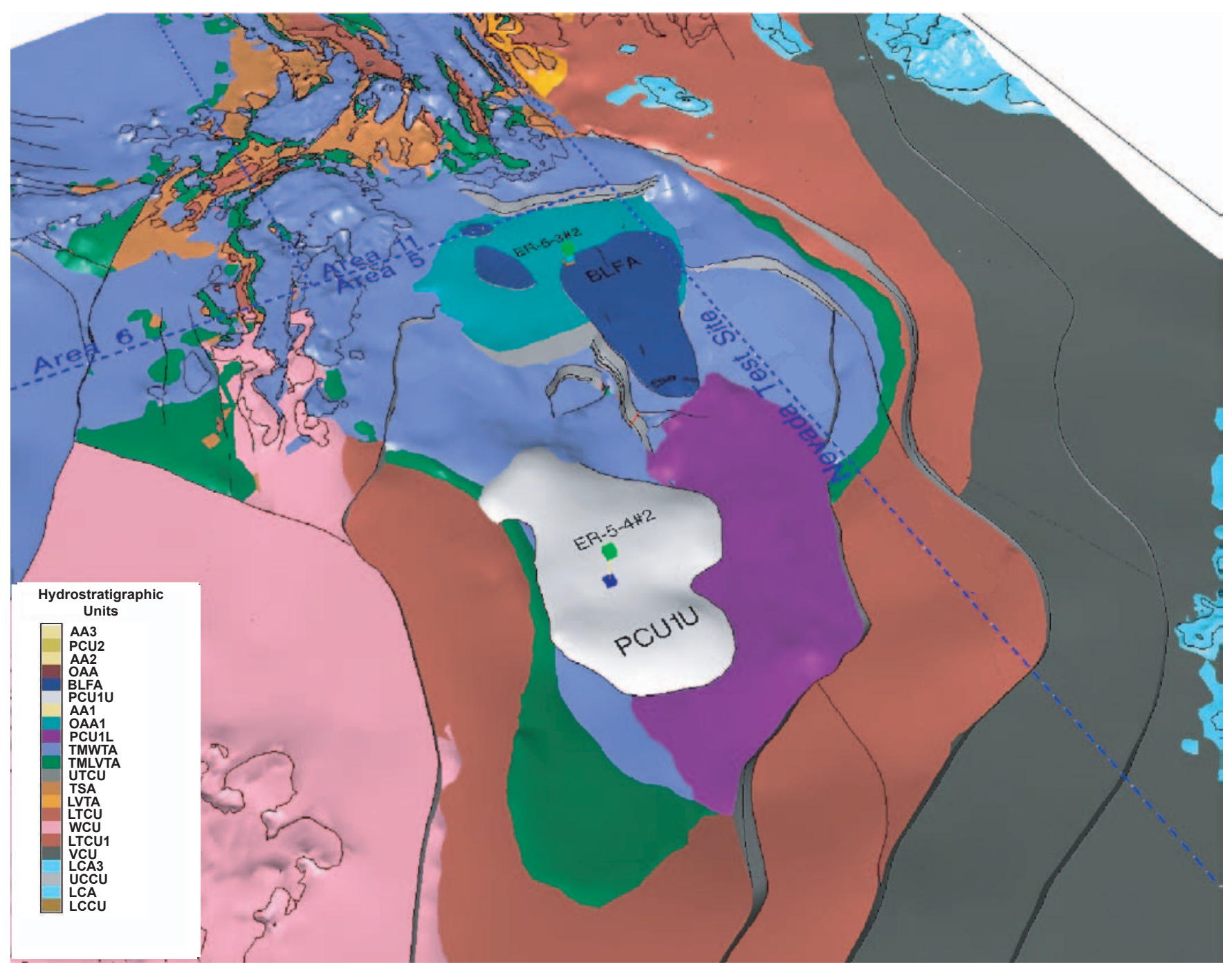

Figure 4-8

Perspective View Showing Extent of the Playa Confining Unit (PCU1U) and the Basalt Lava-Flow Aquifer (BLFA) within the Frenchman Flat Model Area 


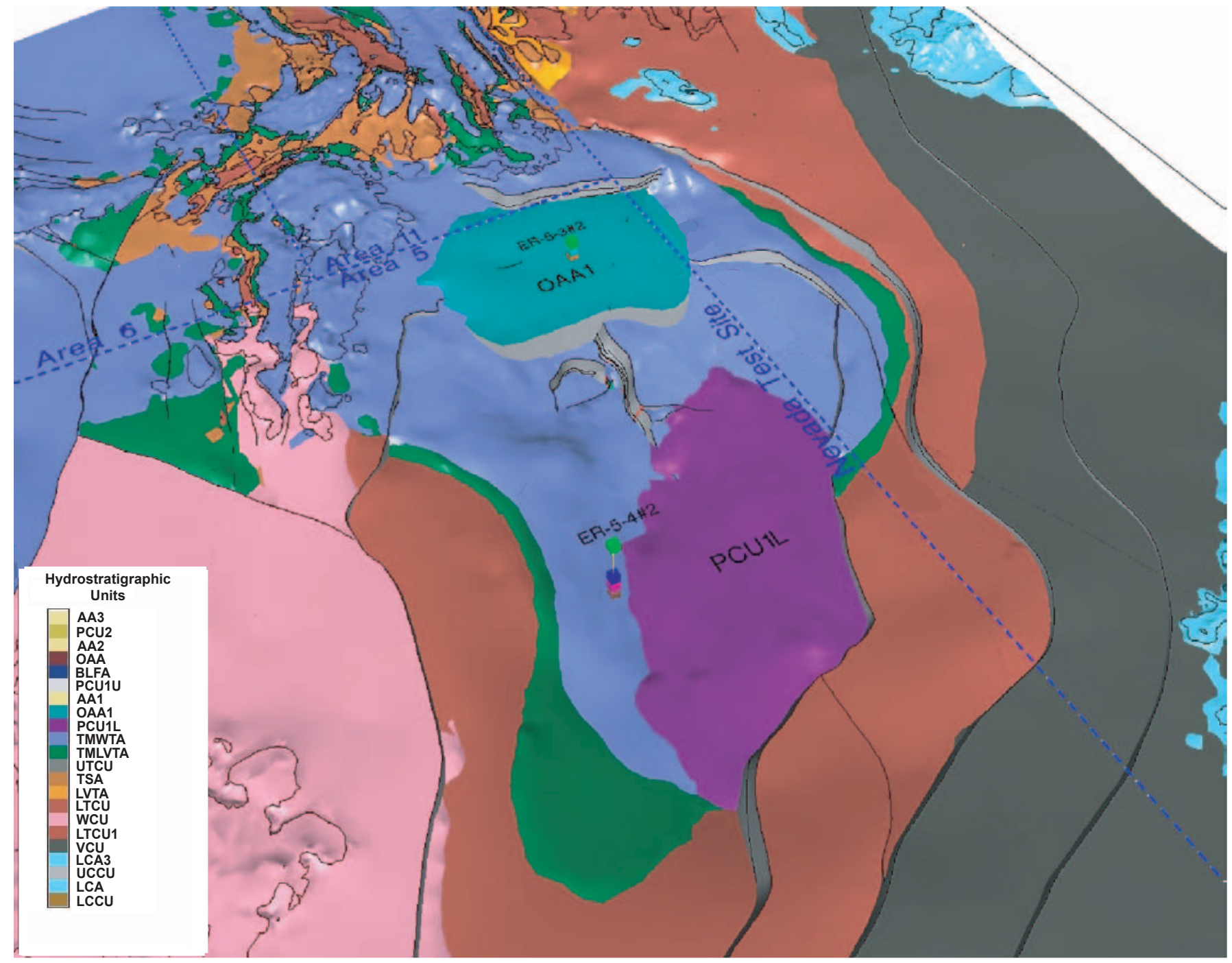

Figure 4-9

Perspective View Showing Extent of the Playa Confining Unit (PCU1L) and the Older Alluvial Aquifer (OAA1) Within the Frenchman Flat Model Area 


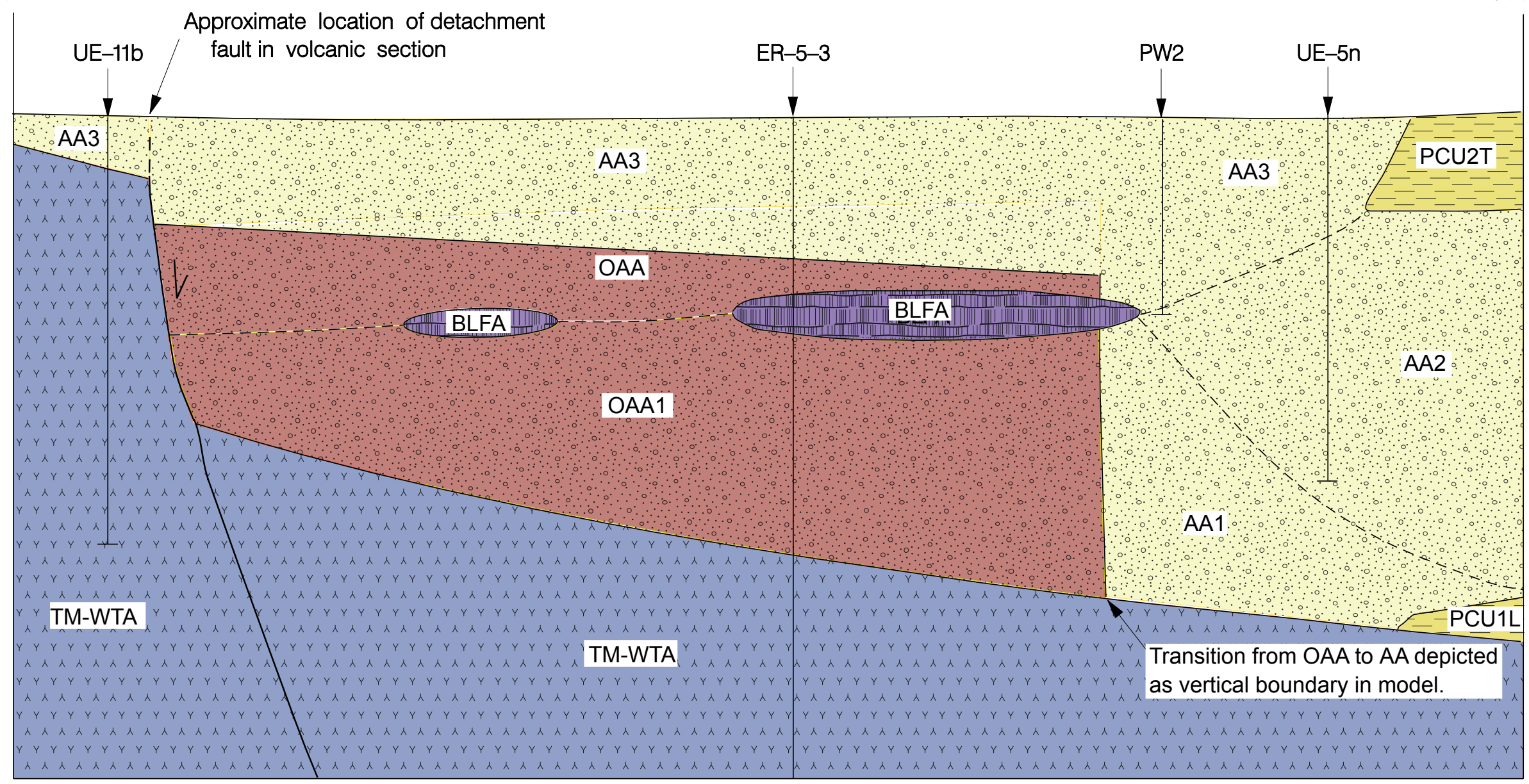

\section{Hydrogeologic Units}

Alluvial aquifer

Lava flow aquifer

Playa confining unit

Welded tuff aquifer

\section{Hydrostratigraphic Units}

AA3 Alluvial aquifer 3 BLFA

AA2 Alluvial aquifer2 OAA

AA1 Alluvial aquifer $1 \quad$ OAA1

PCU2T Playa confining unit 2T

PCU1L Playa confining unit 1 lower
TM-WTA Timber Mountain welded tuff aquifer

Not to scale

Subdivision of the unit into subunits (e.g. AA1, AA2, AA3) is necessary due to software limitations, and does not represent differences in the properties of the unit.

Fault; arrow show sense of movement

Figure 4-10

Schematic North-South Hydrostratigraphic Cross Section Showing Relationships Among the Alluvial Aquifers and the Basalt Lava-Flow Aquifer in Northern Frenchman Flat. 


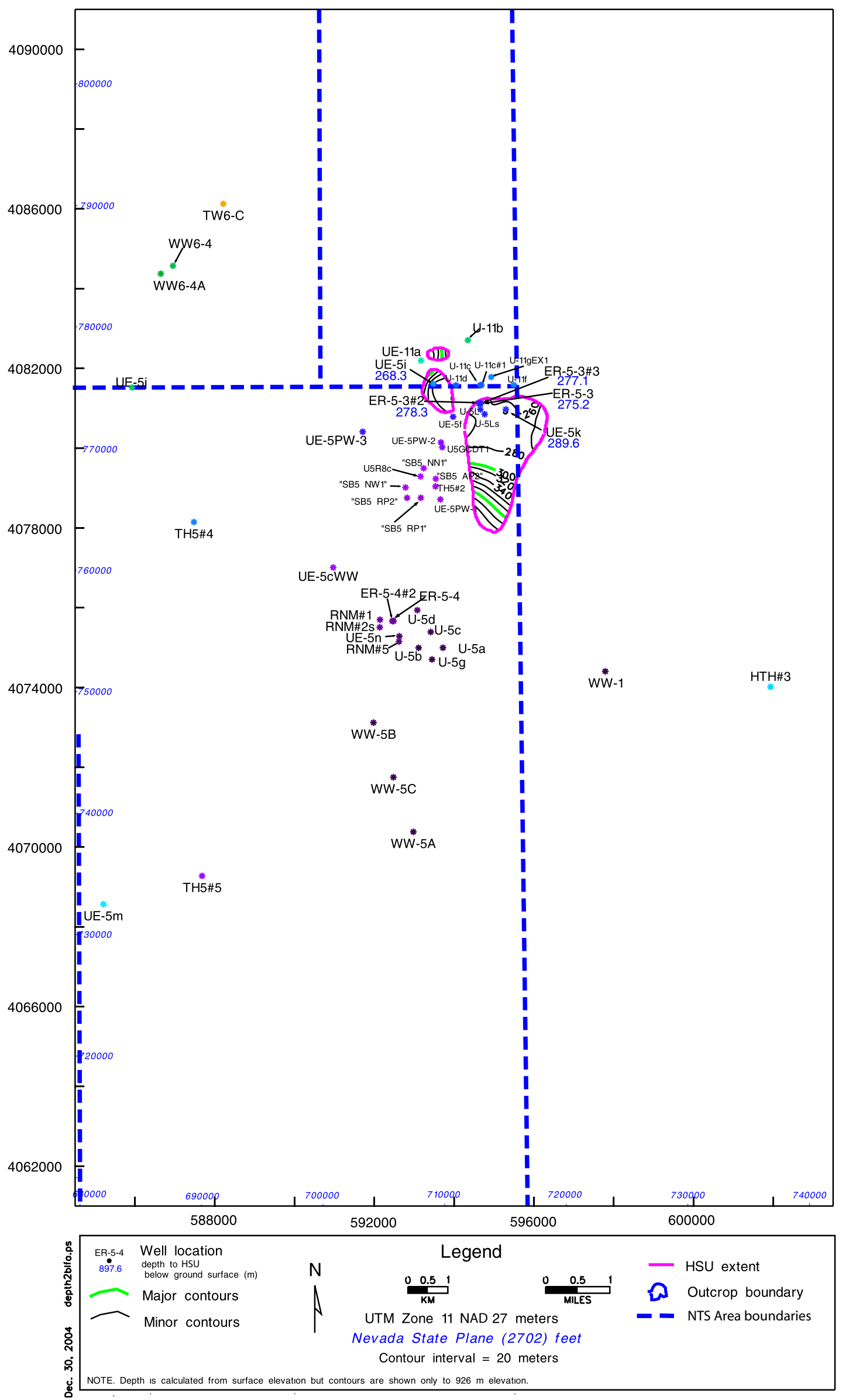

Figure 4-11

Depth to Top of Basalt Lava-Flow Aquifer (BLFA) 


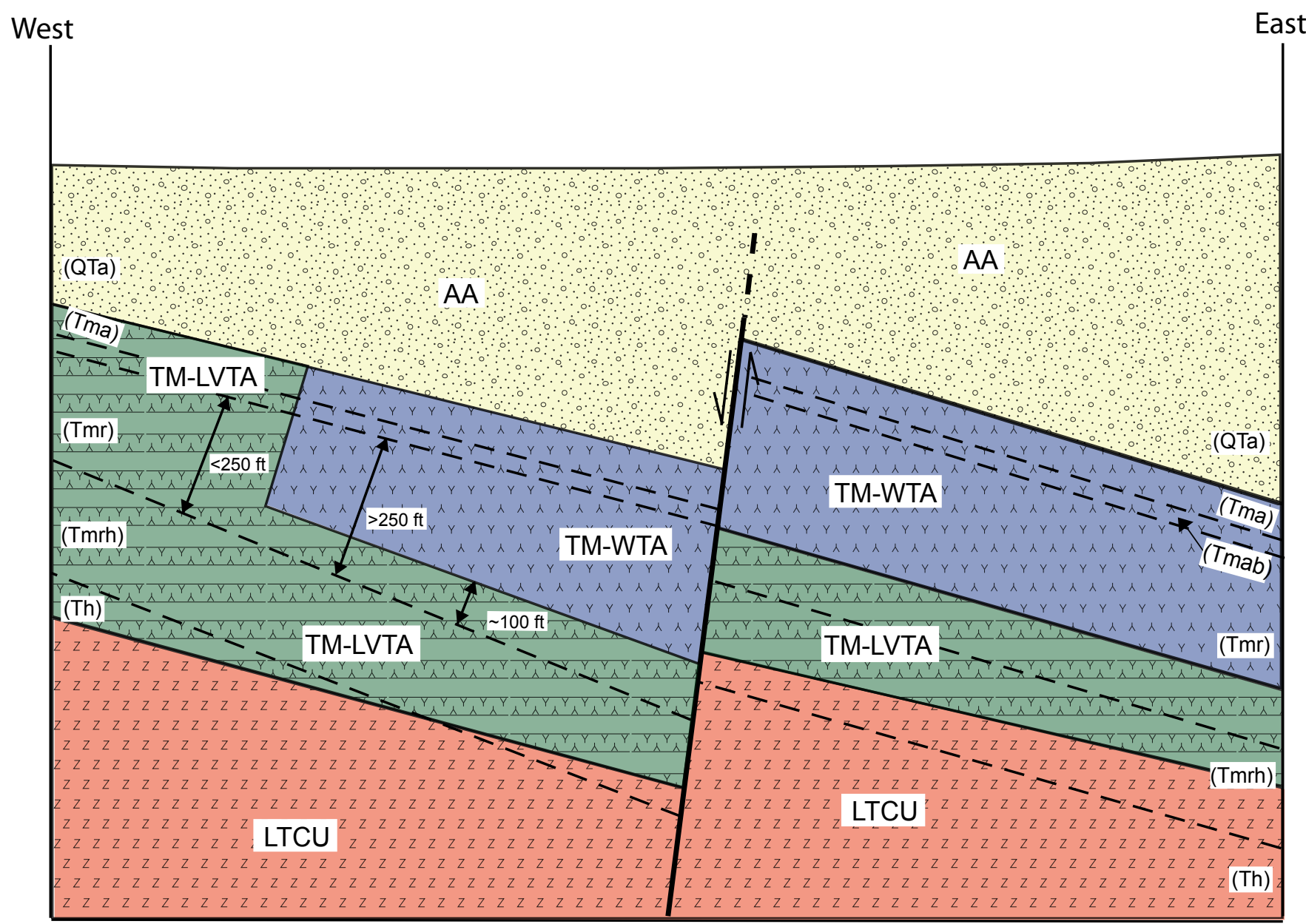

\section{Not to scale}

\section{Hydrogeologic Units}

Alluvial aquifer

$\therefore \wedge$ Welded-tuff aquifer

Vitric-tuff aquifer

$\begin{array}{cc}z \\ z & z\end{array}$ Tuff confining unit

$$
V / / \begin{aligned}
& \text { Fault; arrows showing } \\
& \text { sense of movement }
\end{aligned}
$$

- - Stratigraphic contact

Hydrostratigraphic contact

\section{Hydrostratigraphic Units}

AA Alluvial aquifer

TM-UVTA Timber Mountain upper vitric tuff aquifer

TM-WTA Timber Mountain welded tuff aquifer

TM-LVTA Timber Mountain lower vitric tuff aquifer

LTCU Lower tuff confining unit

\section{Stratigraphic Units}

(QTa) Alluvium

(Tma) Ammonia Tanks Tuff

(Tmab) Bedded Ammonia Tanks Tuff

(Tmr) Rainier Mesa Tuff

(Tmrh) Tuff of Holmes Road

(Th) Calico Hills Formation

Figure 4-12

Schematic West-East Cross Section Across Northern Frenchman Flat Showing Variability in Hydrogeologic Character of the Timber Mountain Hydrostratigraphic Units 
Hydrostratigraphic Units

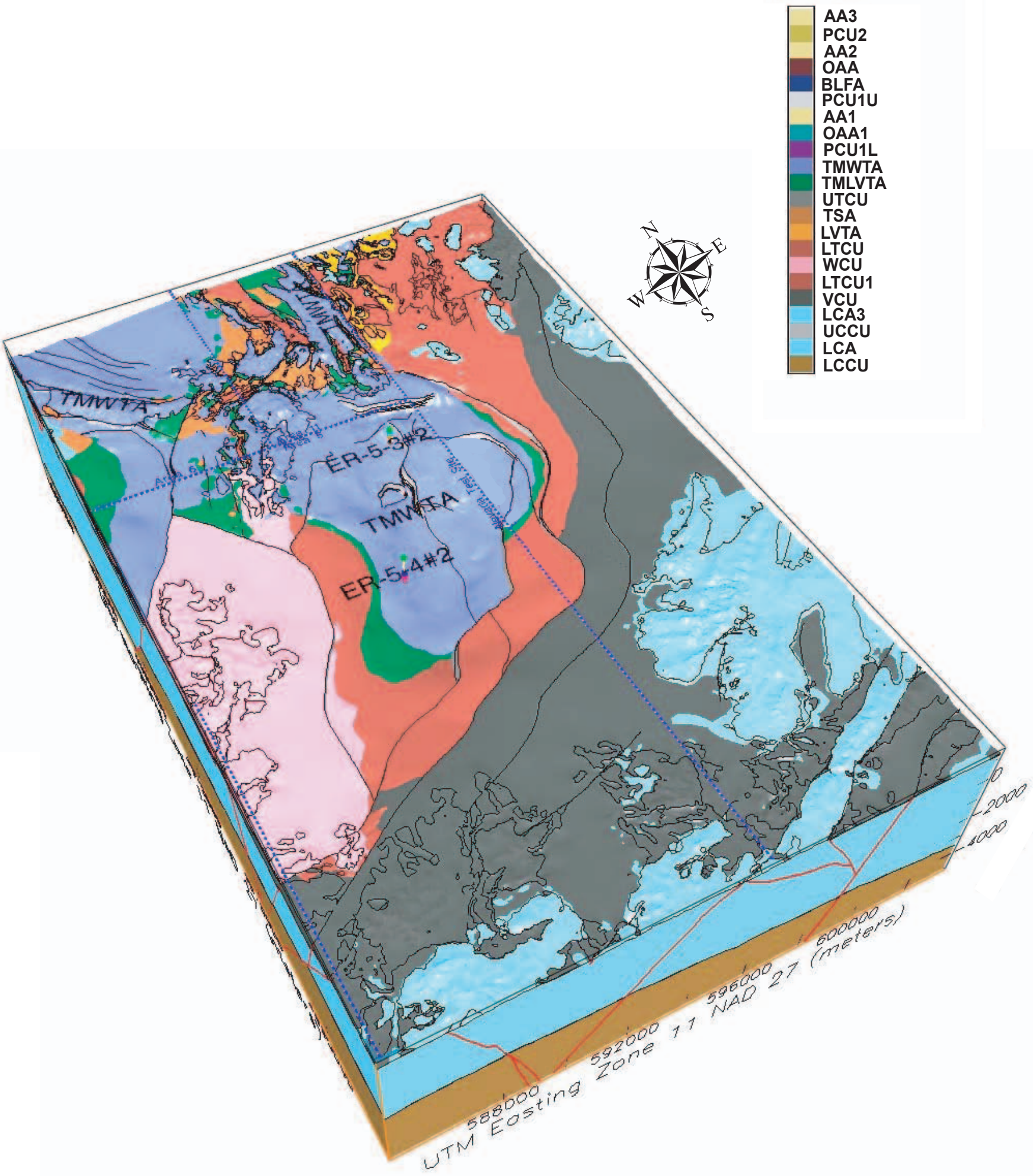

Figure 4-13

Block Model View Showing Extent of the Timber Mountain Welded-Tuff Aquifer (TM-WTA) within the Frenchman Flat Model Area 


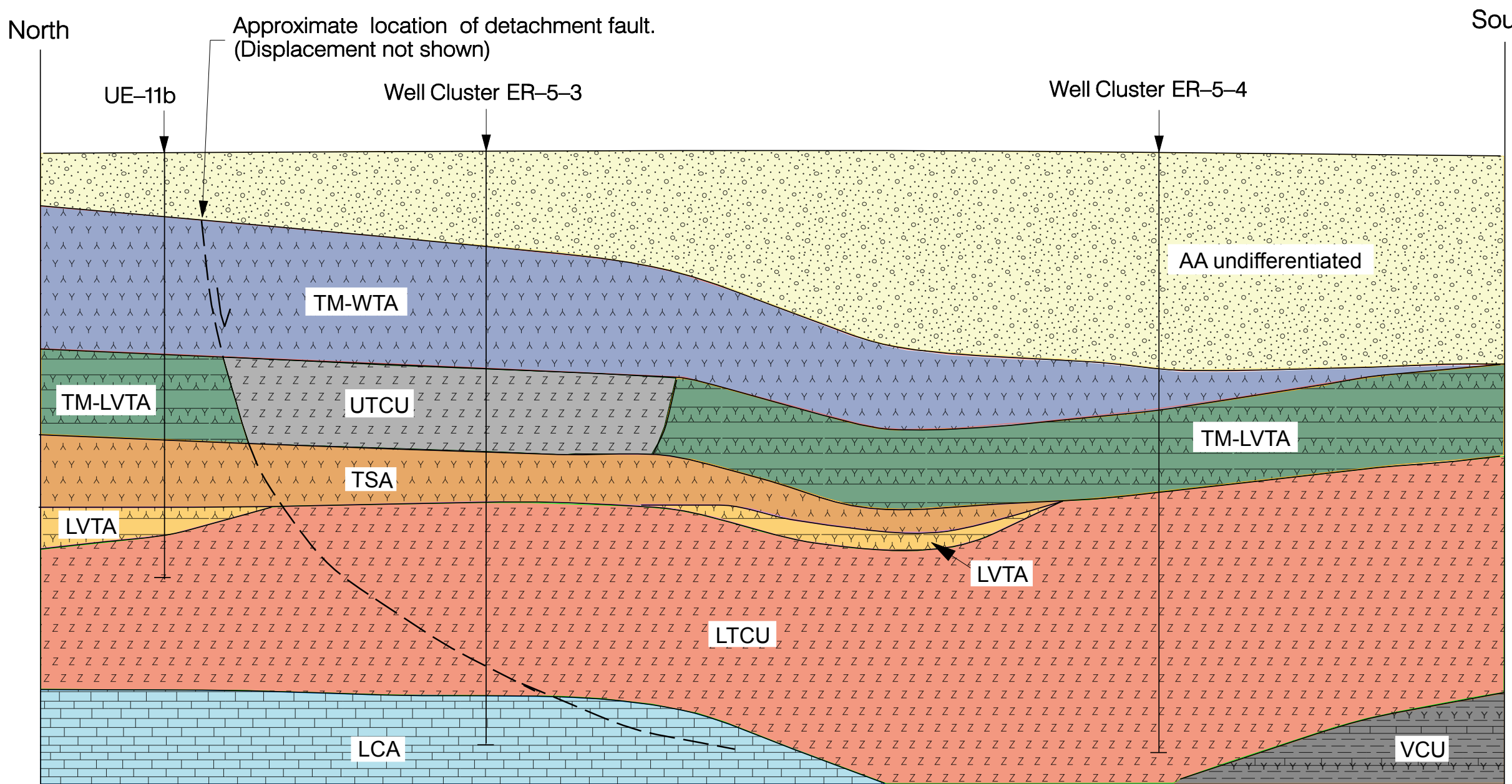

Hydrogeologic Units

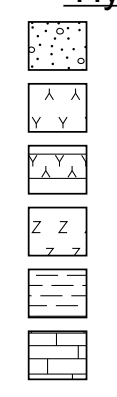

\section{Alluvial aquifer}

Welded tuff aquifer

Vitric tuff aquifer

Tuff confining unit

Volcaniclastic confining unit

Carbonate aquifer

\section{Hydrogeologic Units}

\section{AA Alluvial aquifer}

TM-WTA Timber Mountain welded tuff aqufier

TM-LVTA Timber Mountain lower vitric tuff aquifer

UTCU

TSA Upper tuff confining unit Topopah Spring aquifer

Not to scale.

LVTA

LTCU

VCU

LCA
Lower vitric tuff aquifer Lower tuff confining unit Volcaniclastic congining unit Lower carbonate aquifer
Fault; arrow shows sense of movement

Figure 4-14

Schematic North-South Hydrostratigraphic Cross Section Showing Relationships Among the Volcanic HSUs in Northern Frenchman Flat. 


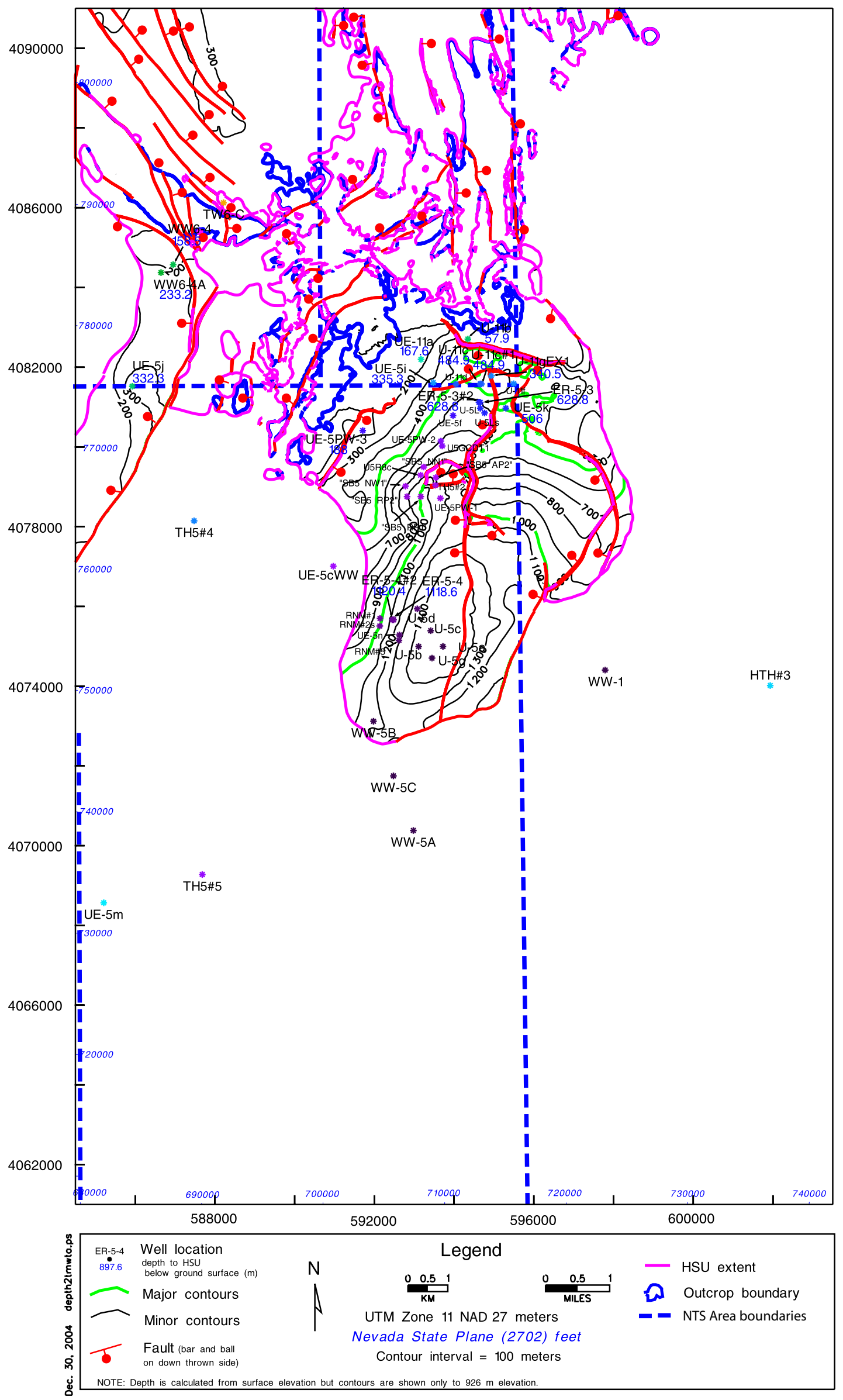

Figure 4-15 
Hydrostratigraphic Units

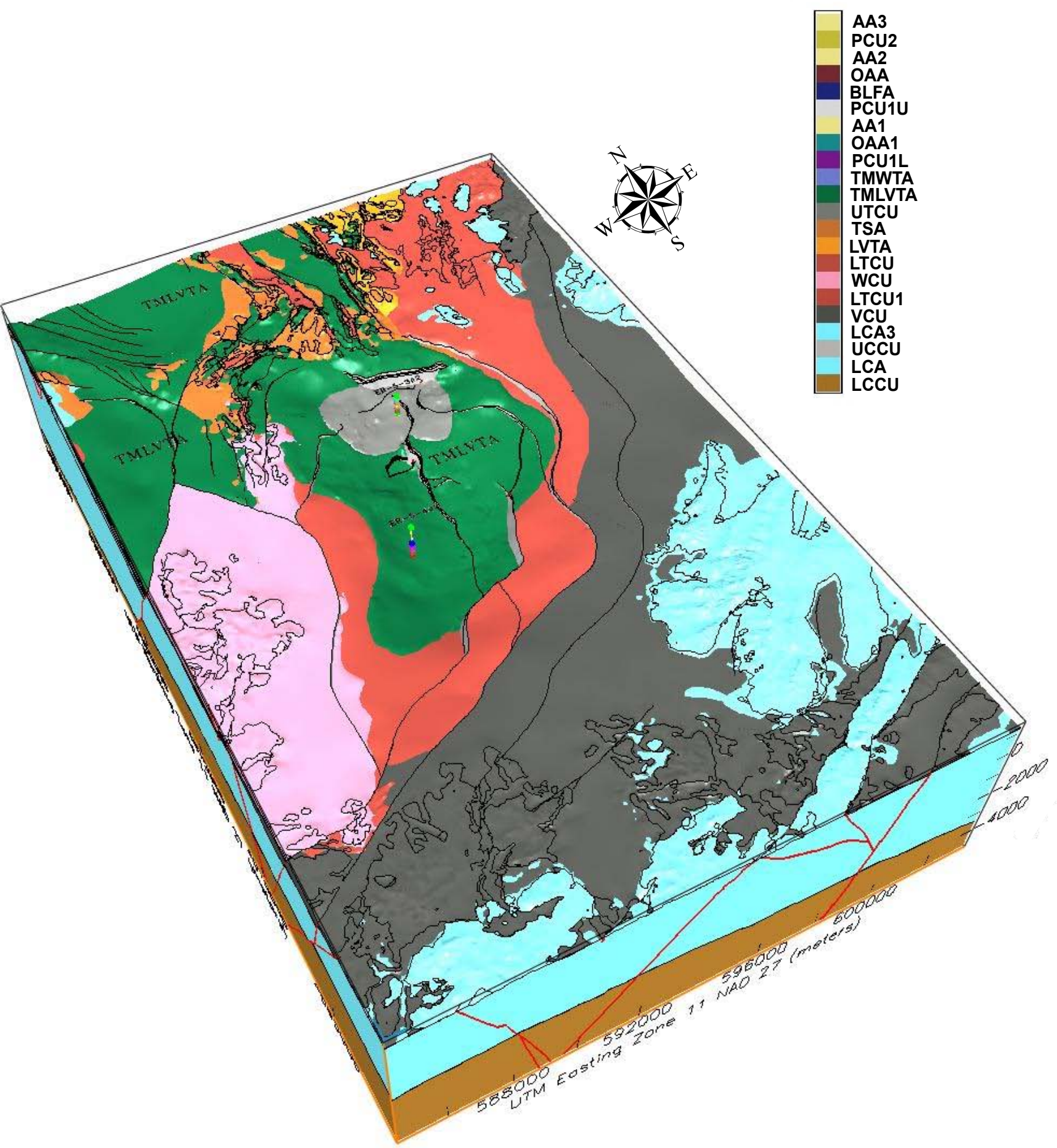

Figure 4-16

Block Model View Showing Extent of the Timber Mountain Lower Vitric-Tuff Aquifer within the Frenchman Flat Model Area 


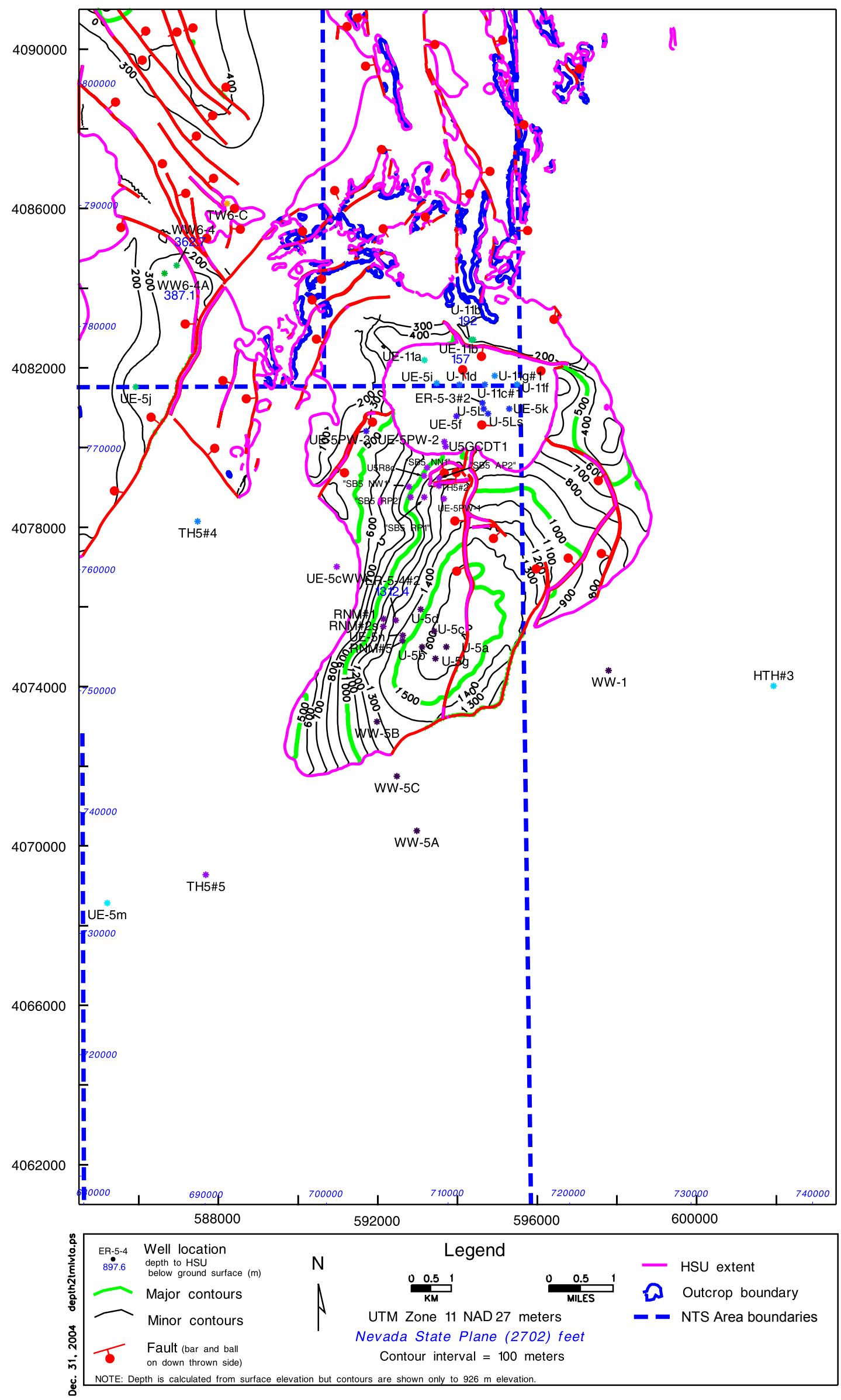

Figure 4-17

Depth to Top of Timber Mountain Lower Vitric-Tuff Aquifer (TM-LVTA) 


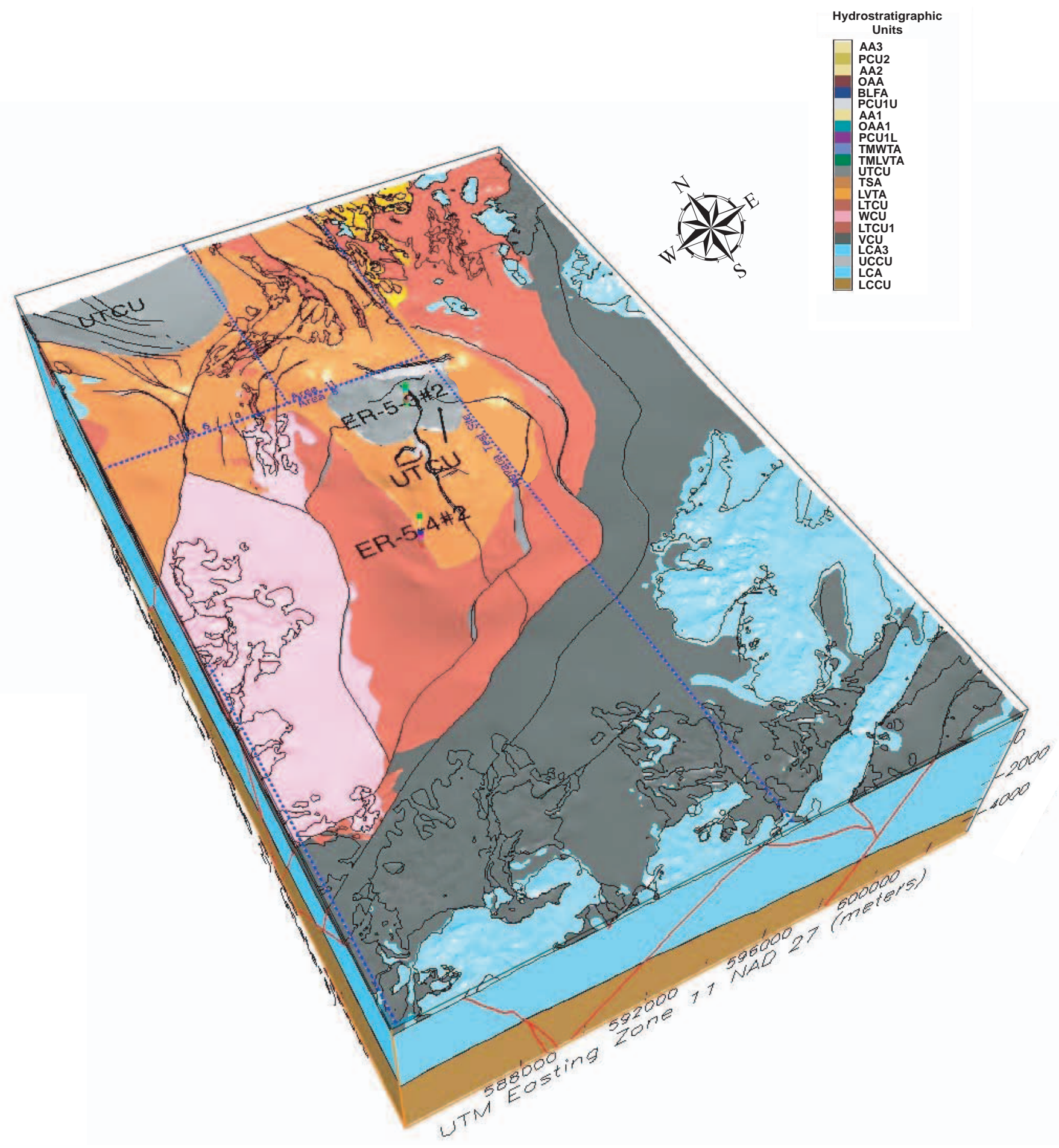

Figure 4-18

Block Model View Showing Extent of the Upper Tuff Confining Unit (UTCU) within the Frenchman Flat Model Area 
Hydrostratigraphic Units

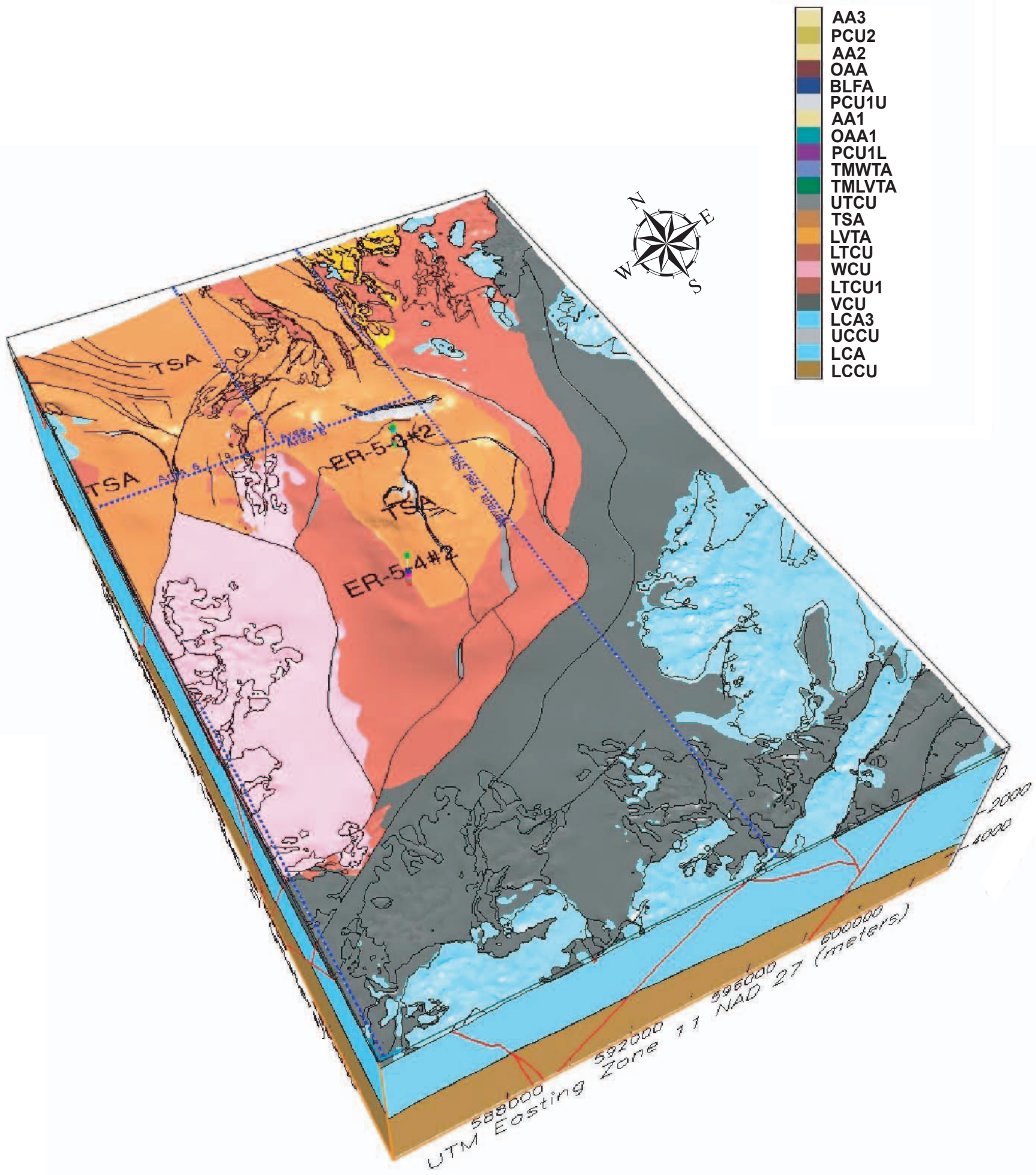

Figure 4-19

Block Model View Showing Extent of the Topopah Spring Aquifer (TSA) within the Frenchman Flat Model Area 


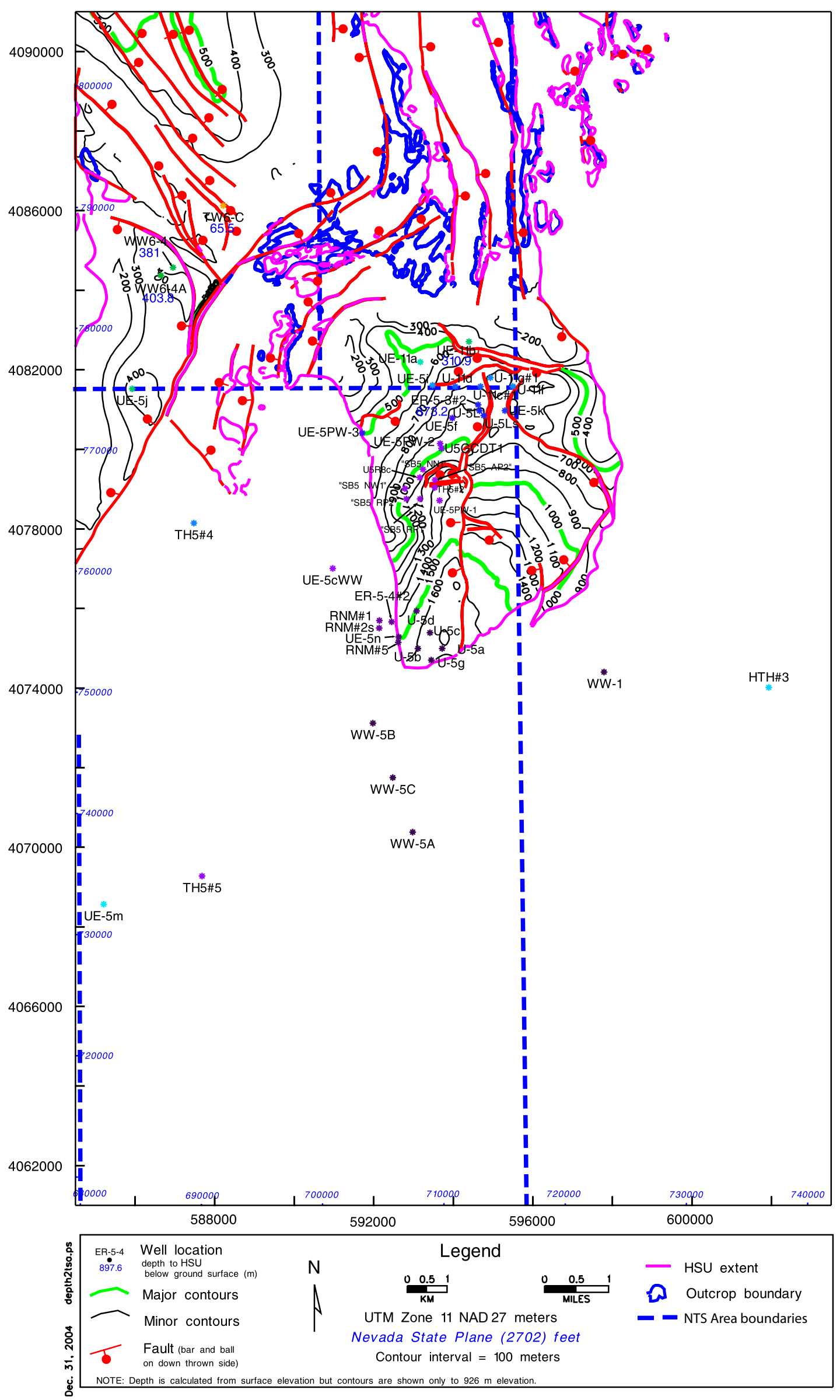

Figure 4-20

Depth to Top of Topopah Spring Aquifer (TSA) 


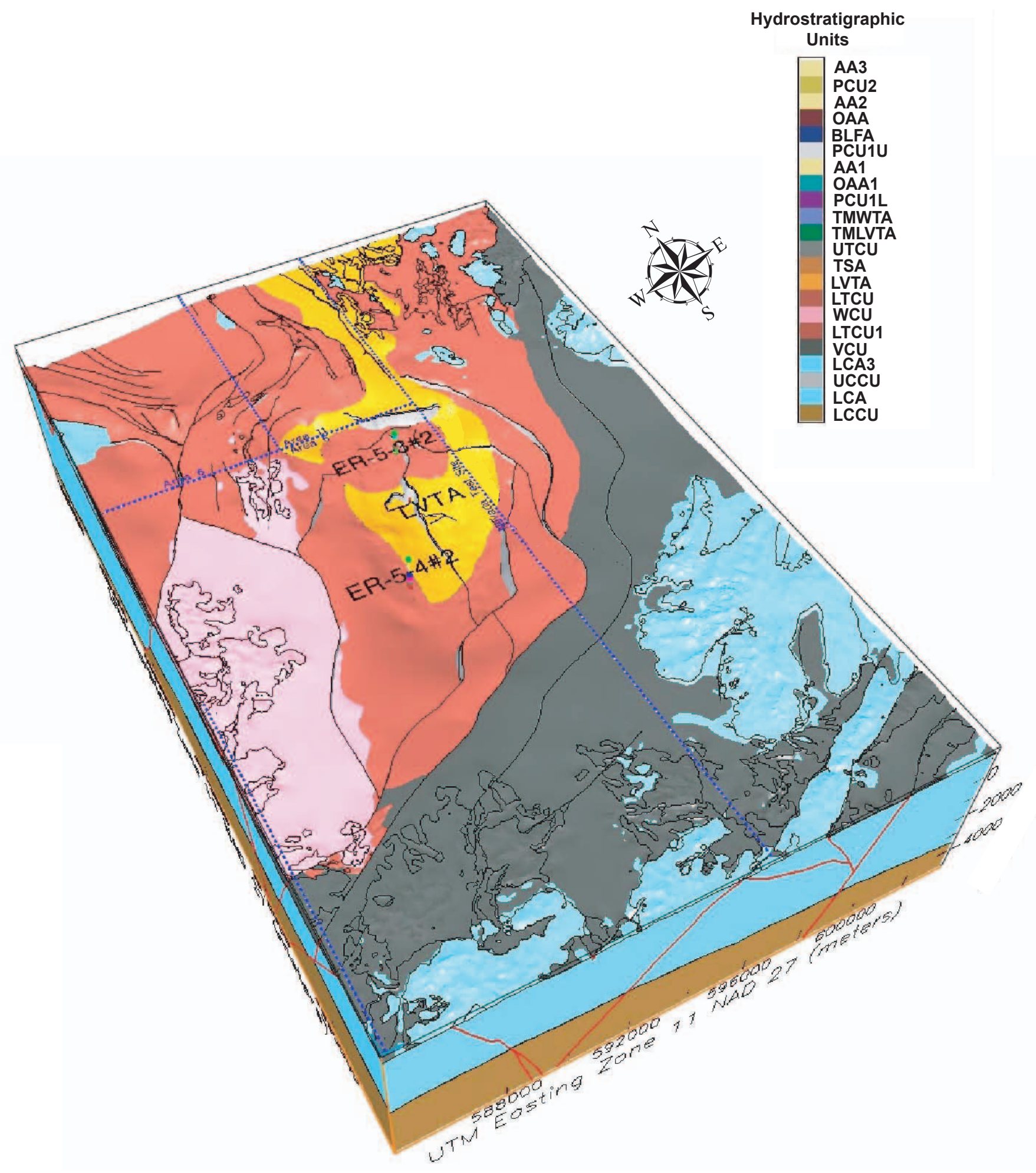

Figure 4-21

Block Model View Showing Extent of the Lower Vitric-Tuff Aquifer (LVTA) within the Frenchman Flat Model Area 

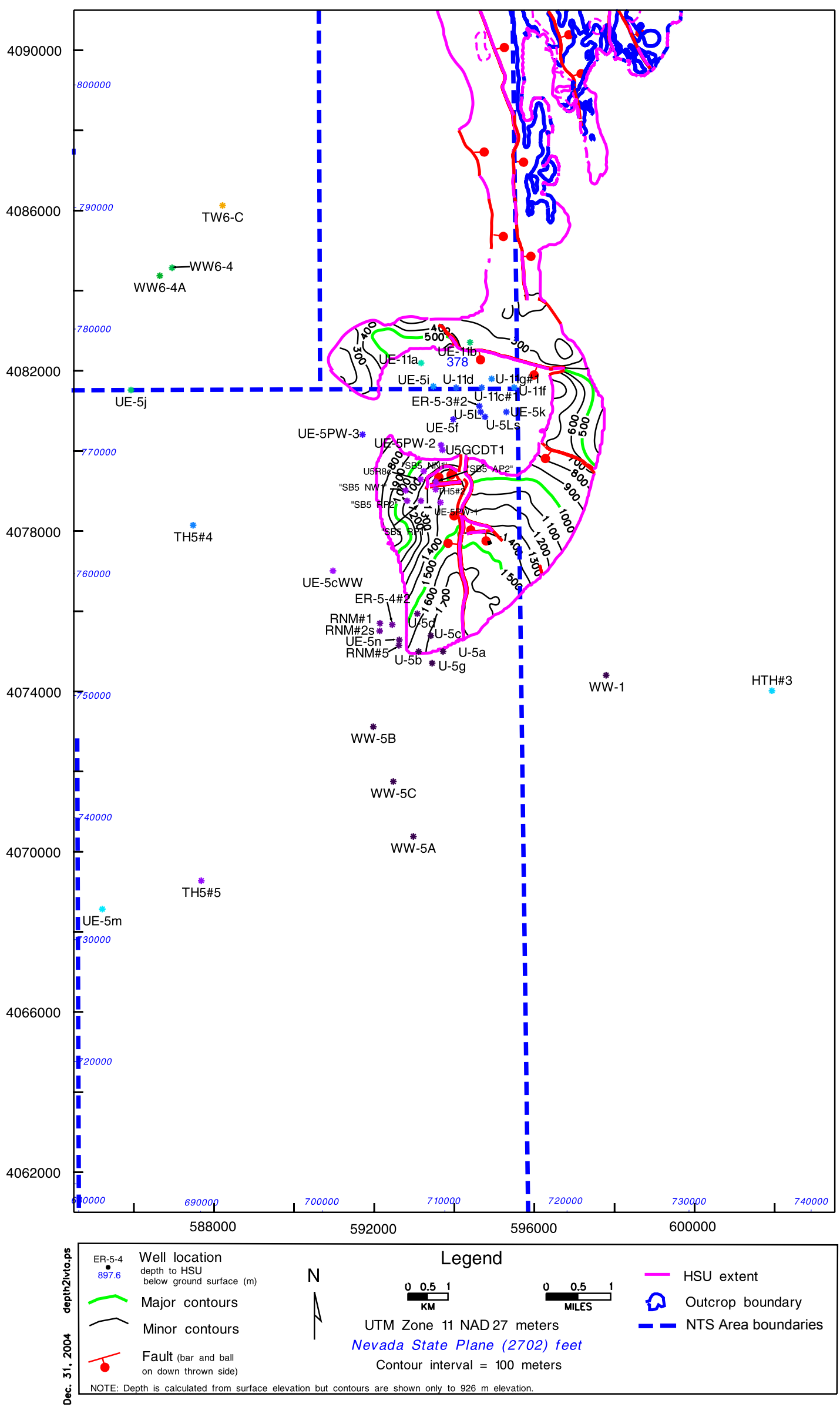

Figure 4-22

Depth to Top of Lower Vitric-Tuff Aquifer (LVTA) 
Hydrostratigraphic

Units

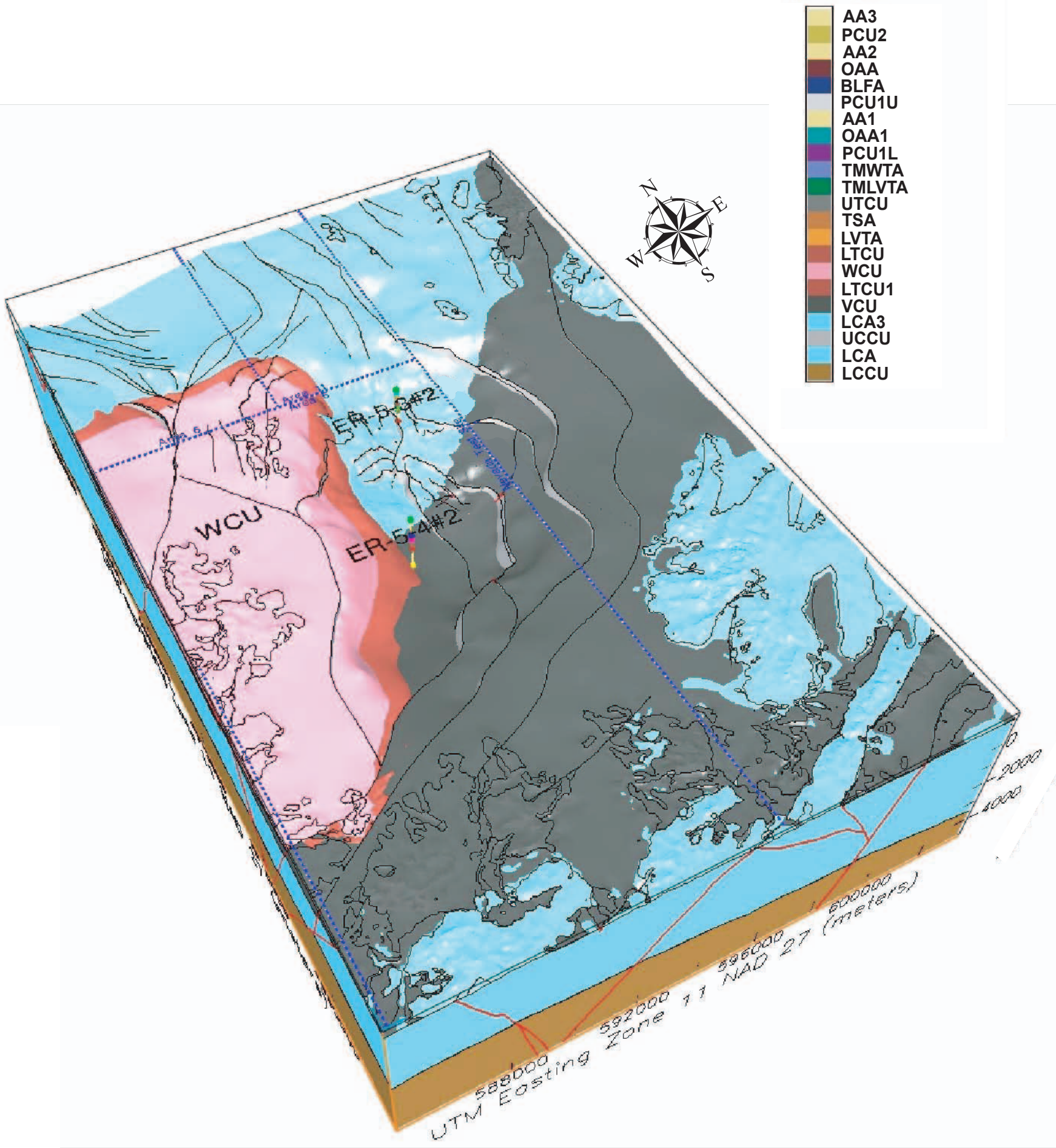

Figure 4-23

Block Model View Showing Extent of the Wahmonie Confining Unit (WCU) within the Frenchman Flat Model Area 


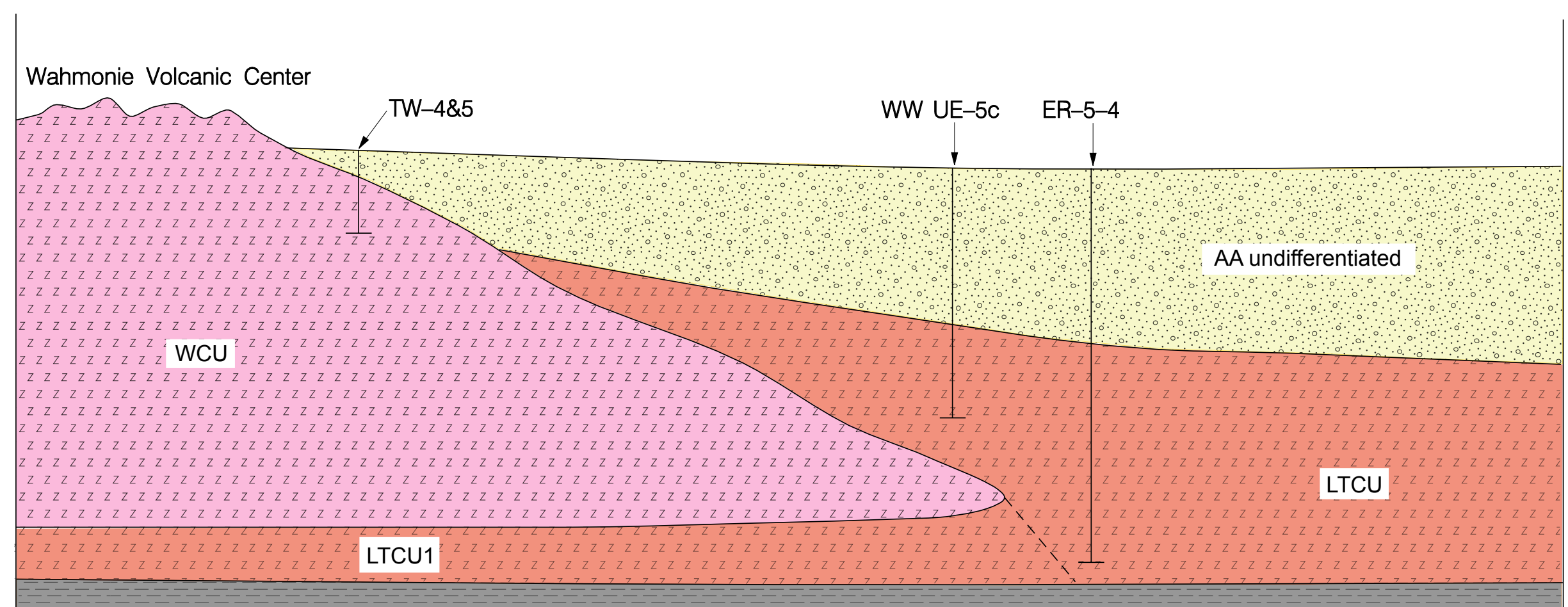

VCU

Hydrogeologic Units

Alluvial aquifer
Carbonate aquifer

Hydrostratigraphic Units

AA Alluvial aquifer

WCU Wahmonie confining unit

LTCU Lower tuff confining unit

VCU Volcaniclastic confining unit

LCA Lower carbonate aquifer
Not to scale

Subdivision of the LTCU into 2 subunits, LTCU, LTCU1, is necessary due to software limitations, and does not represent differences in the properties of the LTCU.

\section{Figure 4-24}

Schematic West-East Hydrostratigraphic Cross Section Through South-Central Frenchman Flat Showing Relationship of the Wahmonie Confining Unit with Other HSUs. 


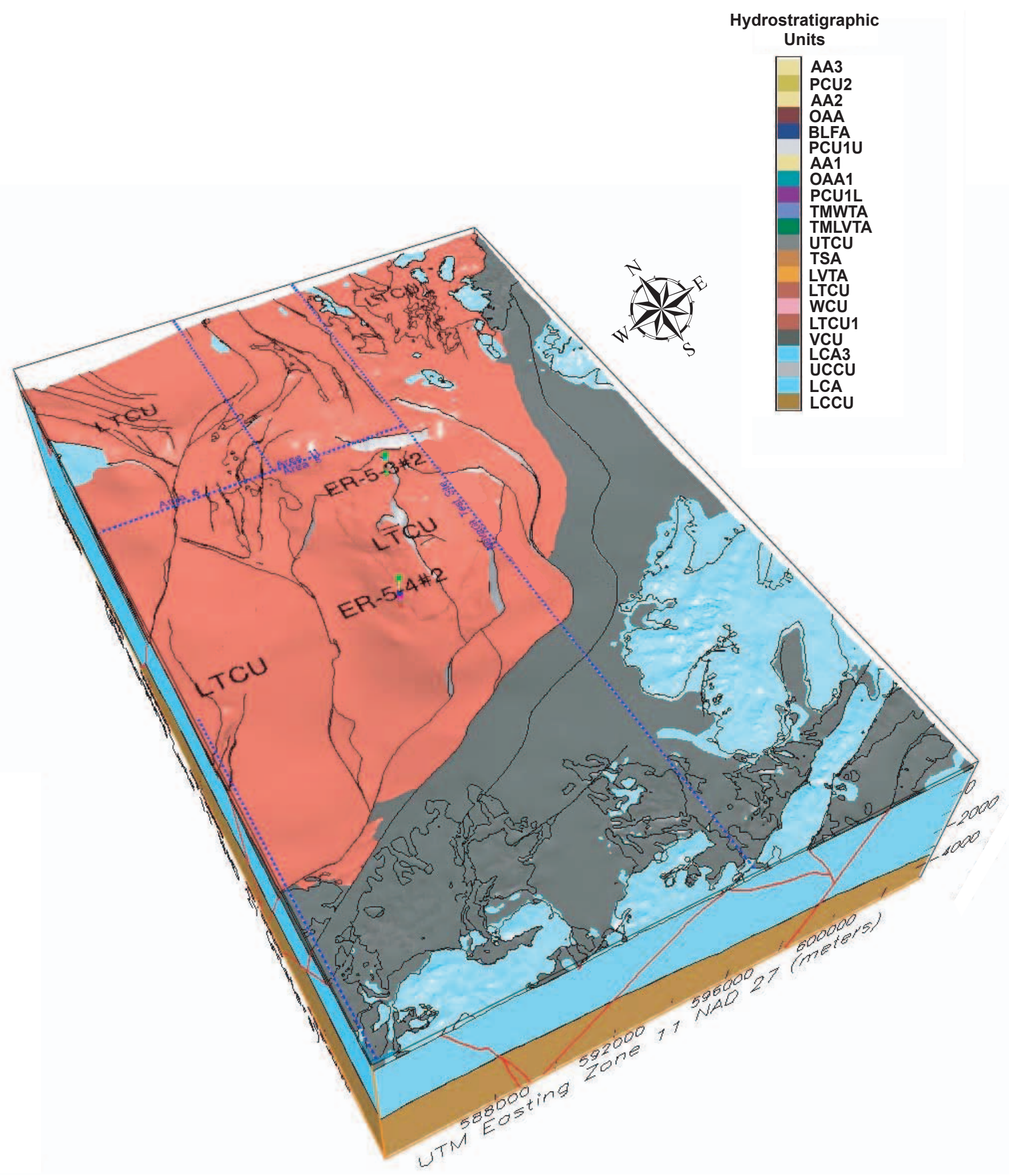

Figure 4-25

Block Model View Showing Extent of the Lower Tuff Confining Unit (LTCU) within the Frenchman Flat Model Area 


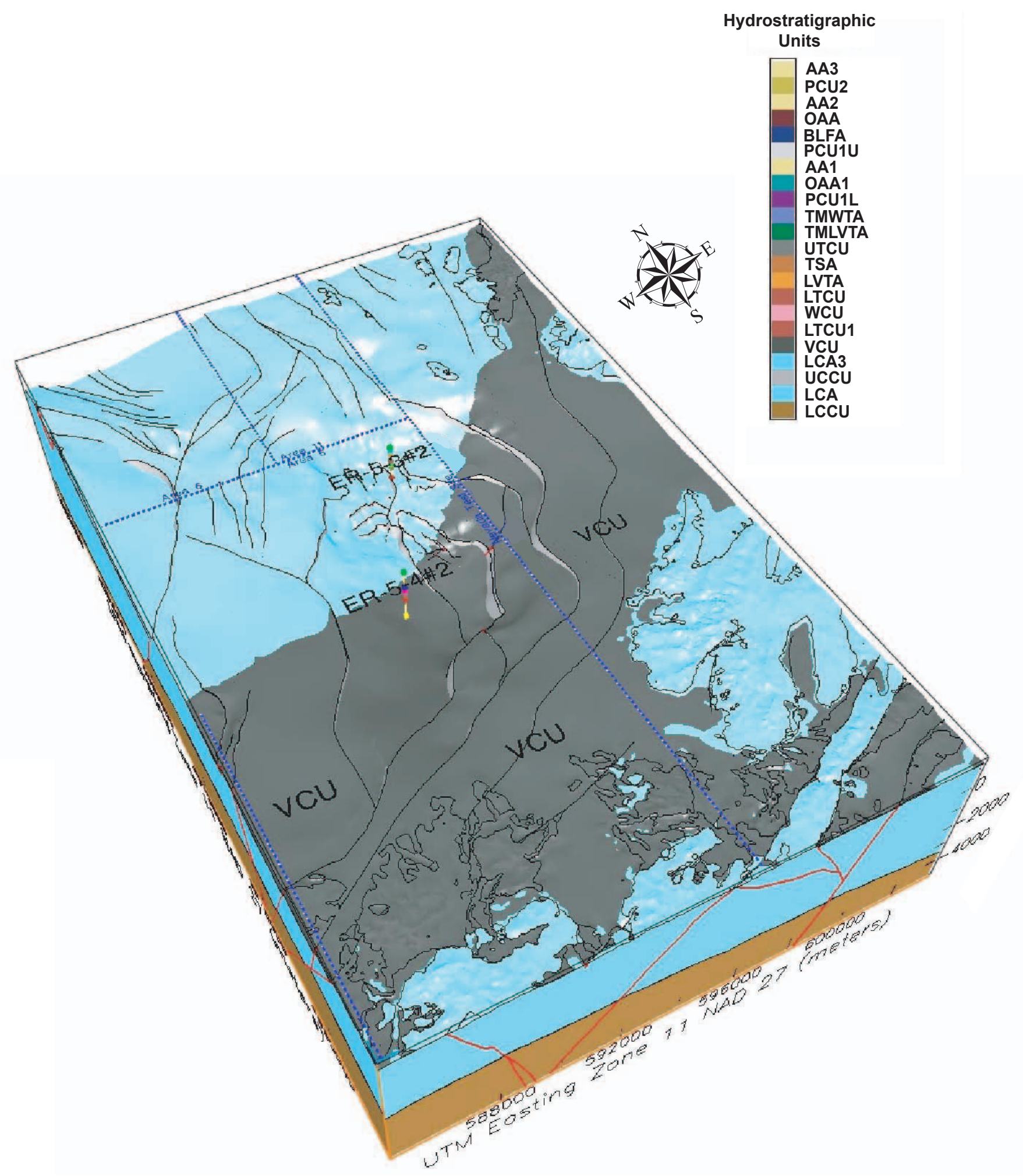

Figure 4-26

Block Model View Showing Extent of the Volcaniclastic Confining Unit (VCU) within the Frenchman Flat Model Area 


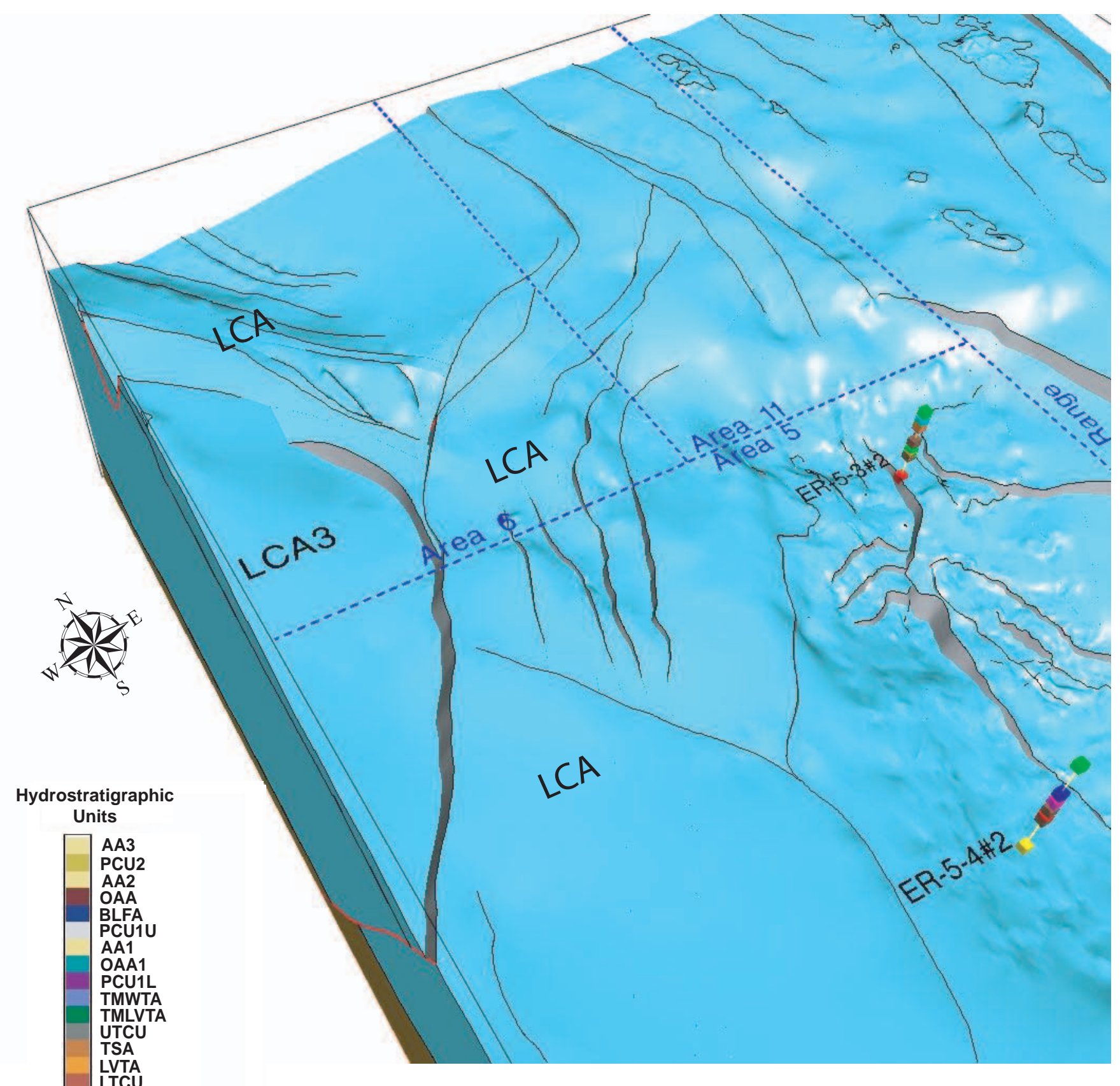

Figure 4-27

Block Model View Showing Extent of the Lower Carbonate Aquifer-Thrust Plate (LCA3) within the Frenchman Flat Model Area 


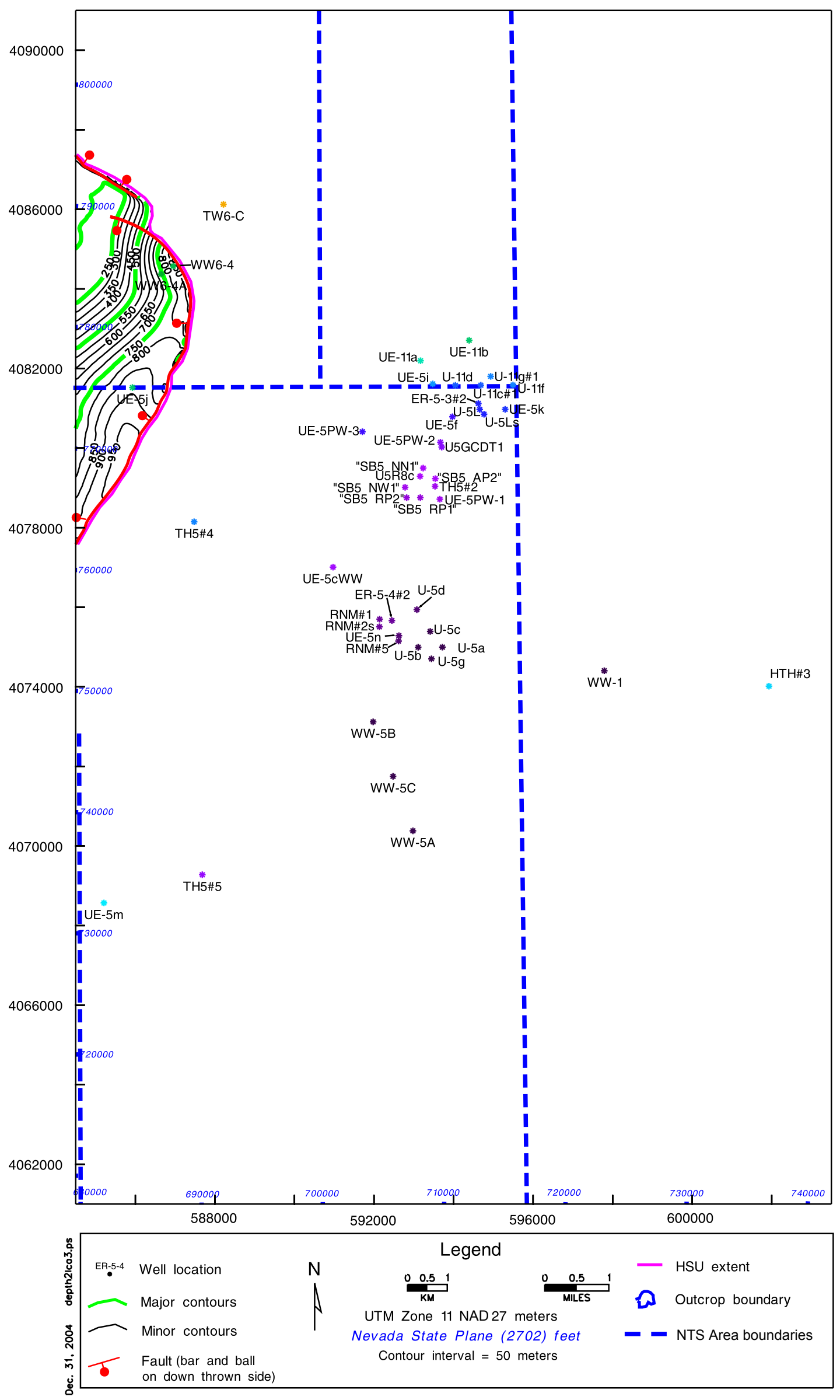

Figure 4-28

Depth to Top of Lower Carbonate Aquifer - Thrust Plate (LCA3) 


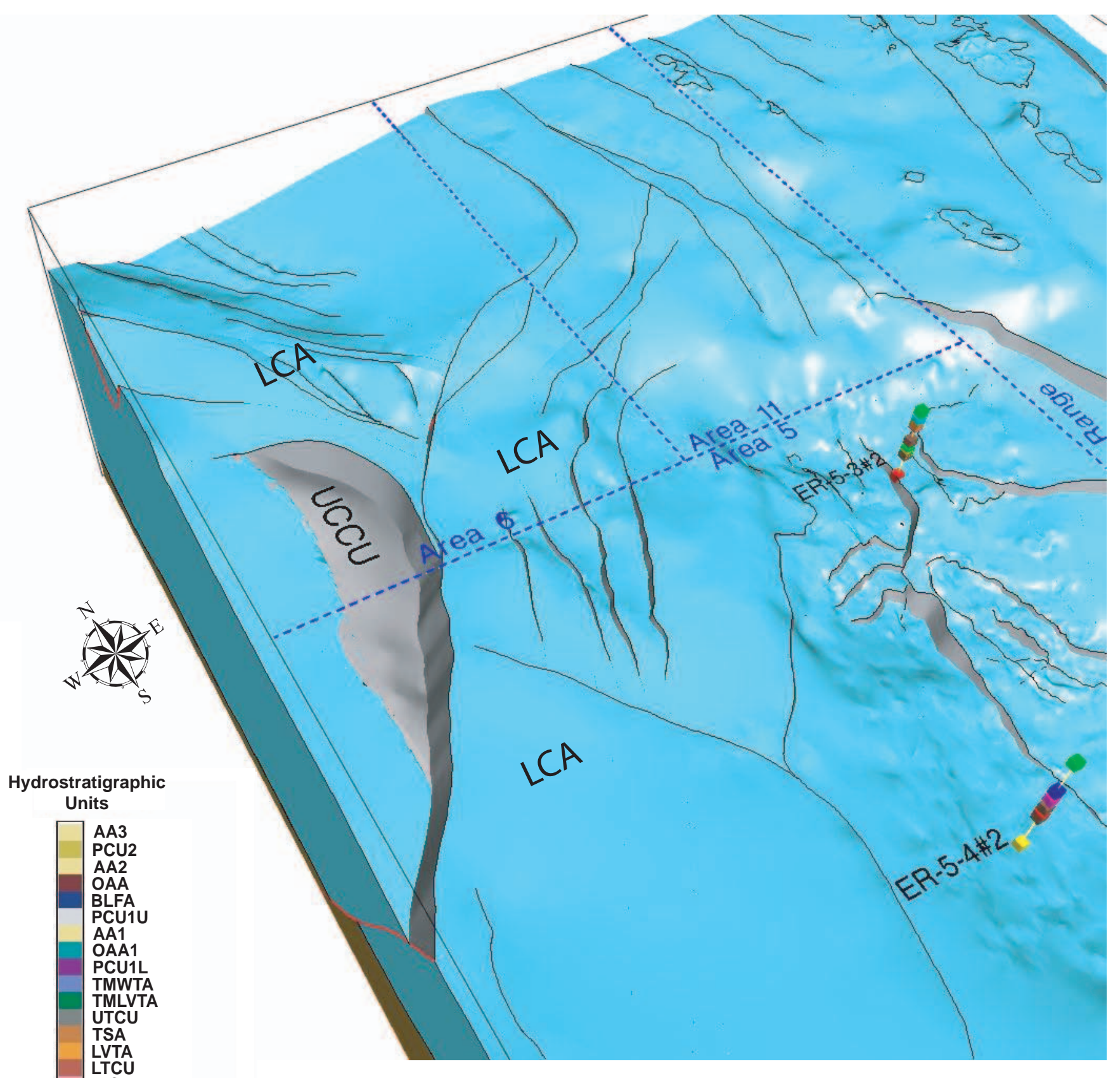

Figure 4-29

Block Model View Showing Extent of the Upper Clastic Confining Unit (UCCU) within the Frenchman Flat Model Area 


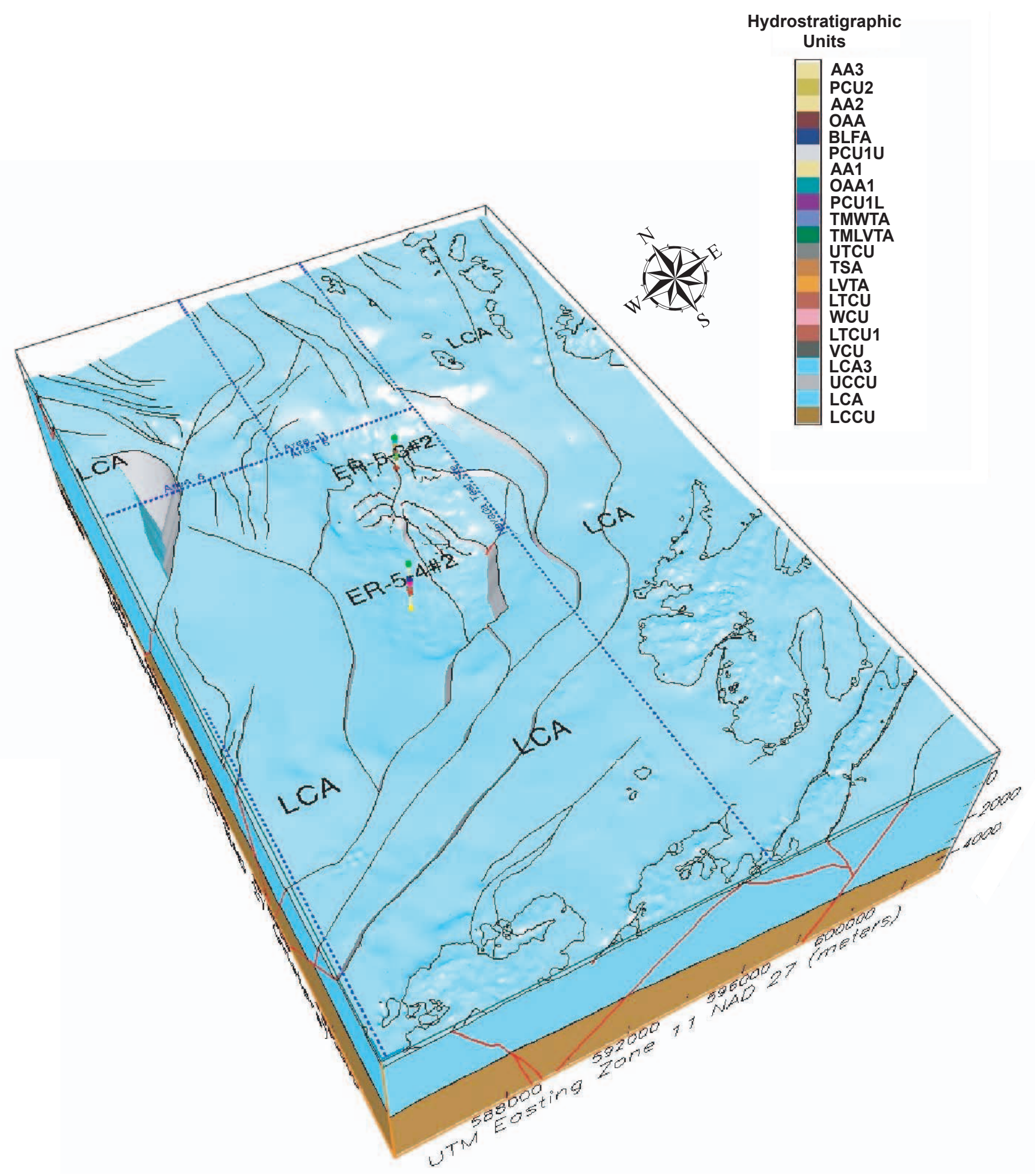

Figure 4-30

Block Model View Showing Extent of the Lower Carbonate Aquifer (LCA) within the Frenchman Flat Model Area 


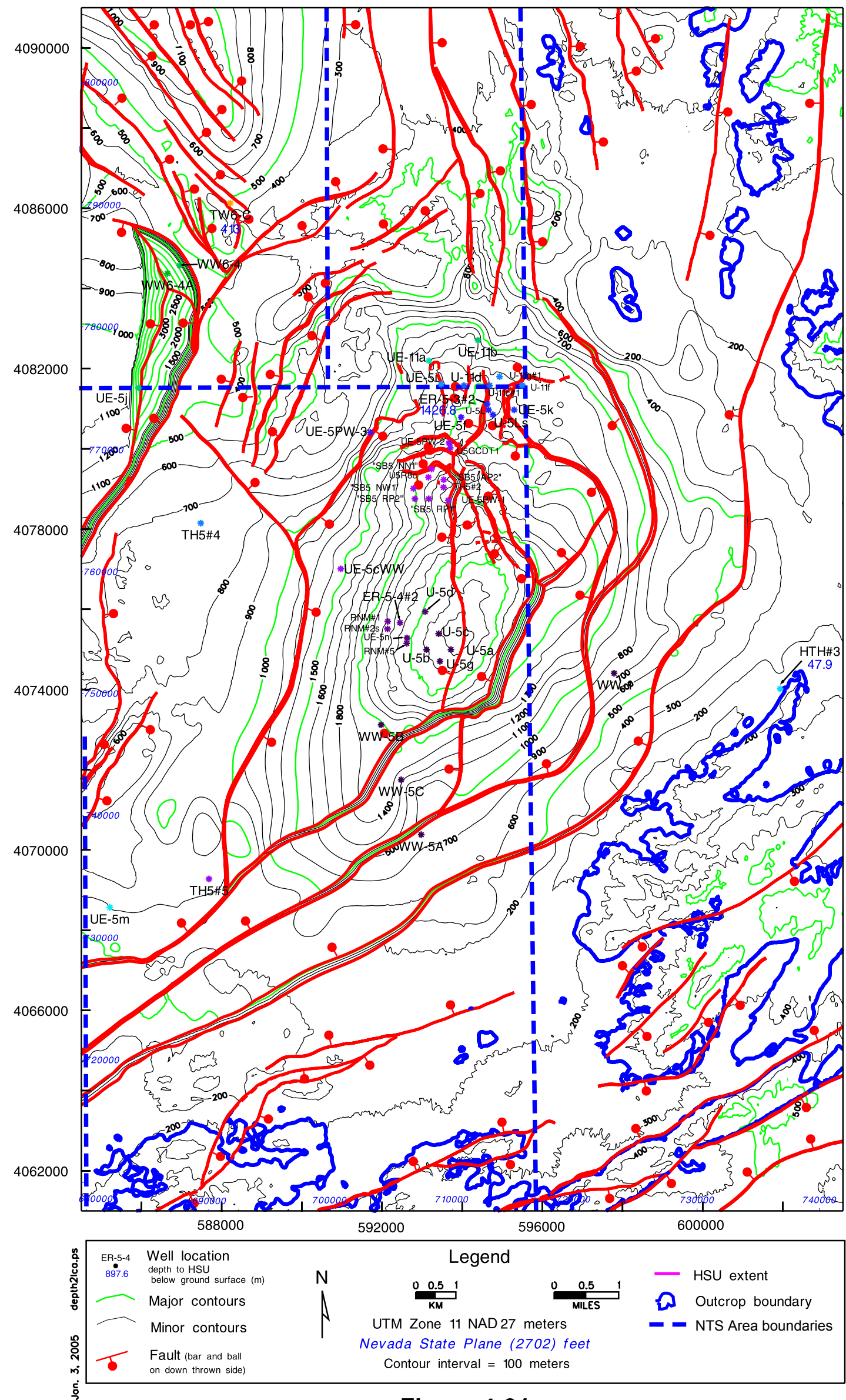

Figure 4-31

Top of Lower Carbonate Aquifer (LCA) 


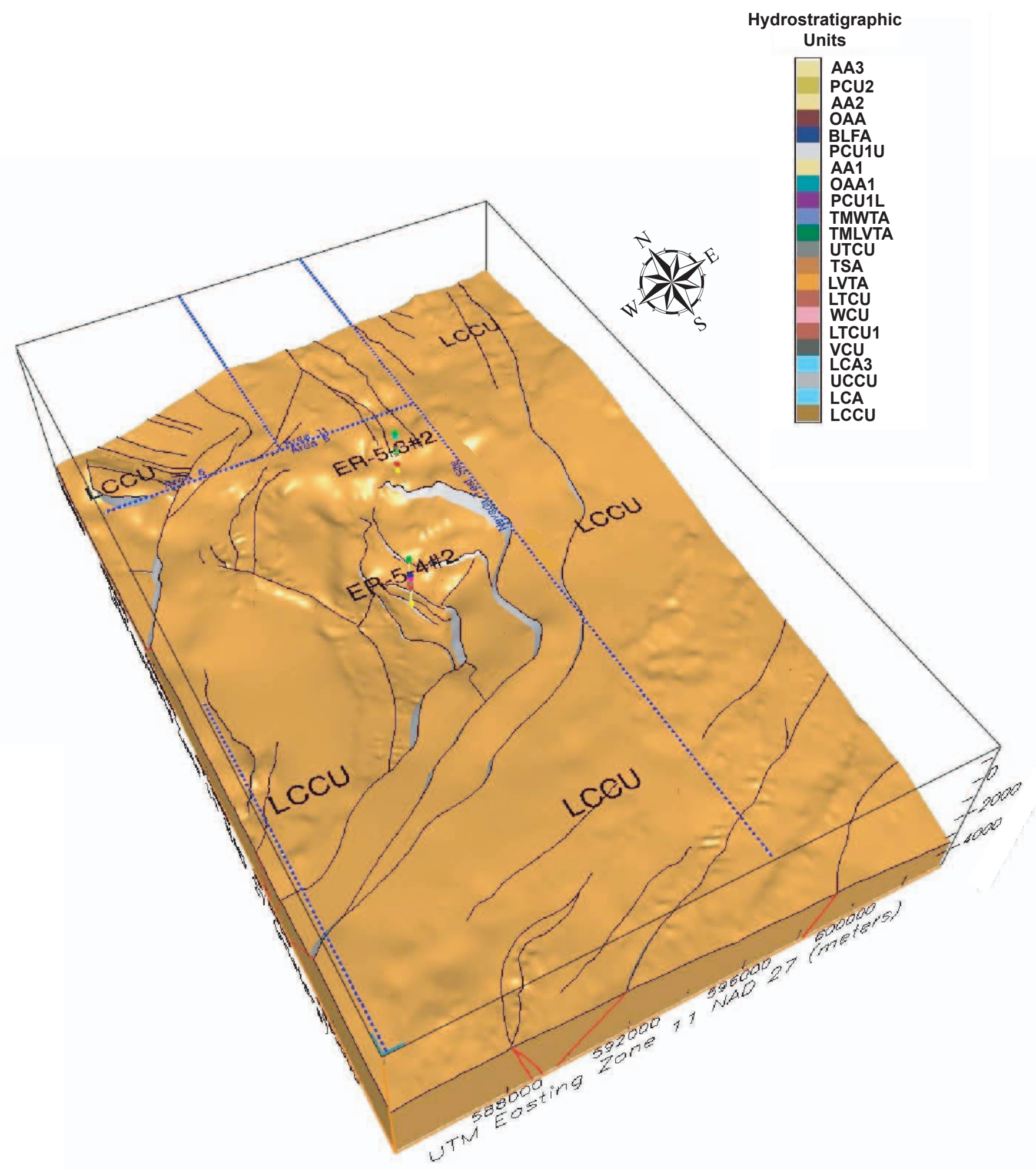

Figure 4-32

Block Model View Showing Extent of the Lower Clastic Confining Unit (LCCU) within the Frenchman Flat Model Area 


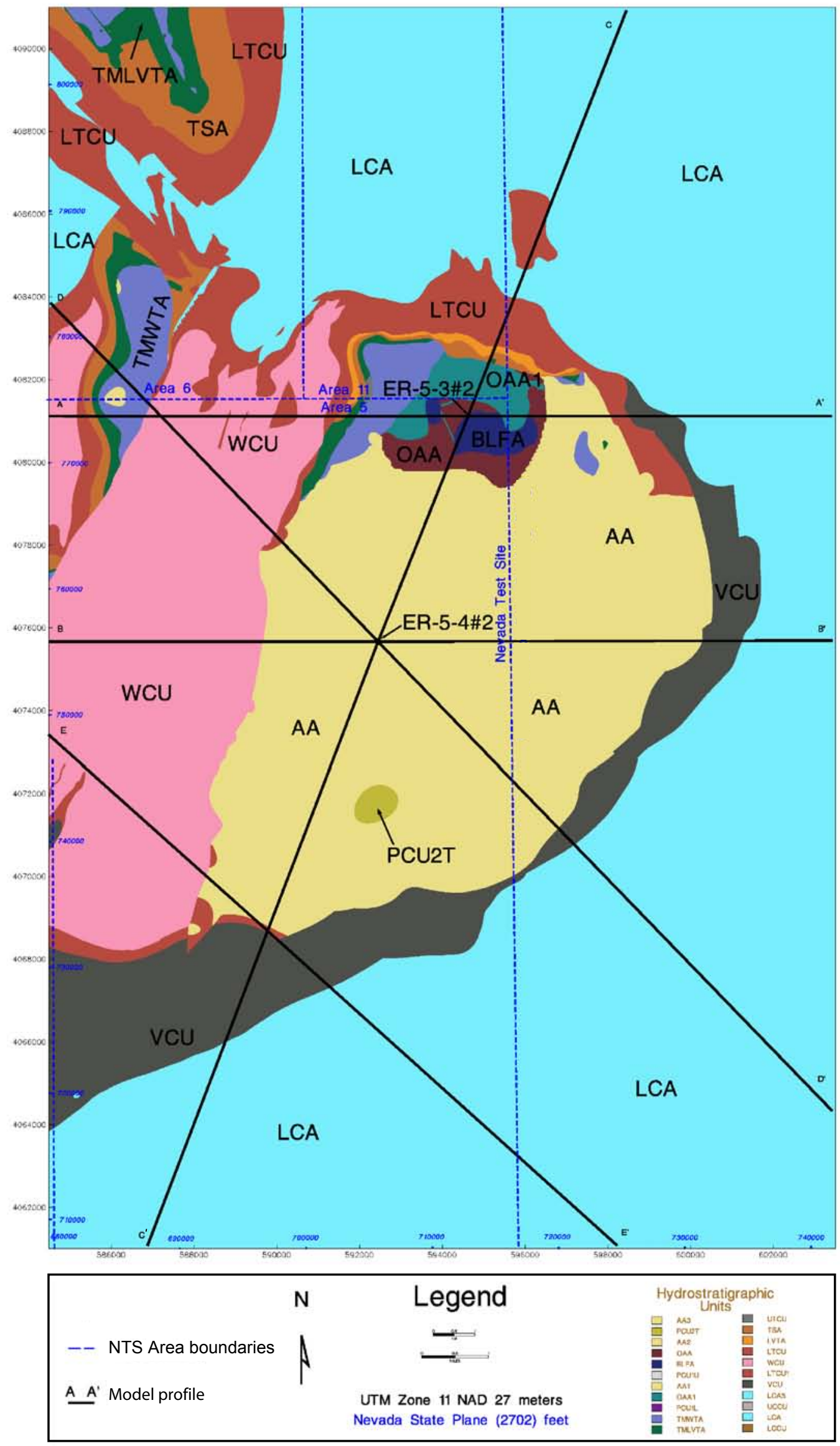

Figure 4-33

Map Showing HSUs at the Water Table within the Frenchman Flat Model Area 


\subsection{ALTERNATIVE SCENARIOS}

As mentioned in previous sections of this report, the geologic complexity of the model area and non-unique interpretations incorporated into the base model made it necessary to address alternative interpretations for some of the more significant features in the model. This section describes the four alternative scenarios developed into separate models, as well as the process used to identify and construct the alternatives.

\subsection{Process of Addressing Alternatives to the Base Model}

Twenty-eight ideas for alternative interpretations to the base model were identified and evaluated during construction of the Phase II base framework model (Table 5-1). These alternatives included ideas from the original Phase I model (IT, 1998a) and alternative interpretations identified by the model builders during construction of the Phase II model. These alternative ideas were presented to the UGTA TWG pre-emptive review committee for their consideration and evaluation, and to solicit additional alternative ideas. Each alternative idea was evaluated and categorized. The main criterion for evaluating and categorizing alternatives was whether the proposed change or alternative interpretation had the potential to significantly affect groundwater flow and contaminant transport. The geological probability and how well constrained each alterative idea was also considered. Simplification of portions and specific aspects of the base model were also considered to explore ways to reduce future flow-andtransport modeling efforts without compromising the integrity of the base model.

The alternatives were grouped into four priority categories. Category A alternatives were ideas judged to be significant and viable enough to be included in the base model. Three alternatives were grouped as category A and incorporated directly into the base model. Two of these alternatives replaced base model interpretations that were subsequently developed as alternative models (see below).

Four alternative ideas were grouped as category B alternatives. These alternatives were judged to be significant enough to develop as separate models. Each alternative was inserted into a copy of the base model, resulting in four separate alternative models. Two of these were originally included in the draft base model, but were switched out for alternative ideas.

Category C alternatives were judged to be potentially significant, but might be further evaluated during flow modeling. If judged to be significant by the flow modelers, these alternative ideas 
Table 5-1

Abridged List of Alternative Scenarios for the Frenchman Flat 3-D Hydrostratigraphic Model

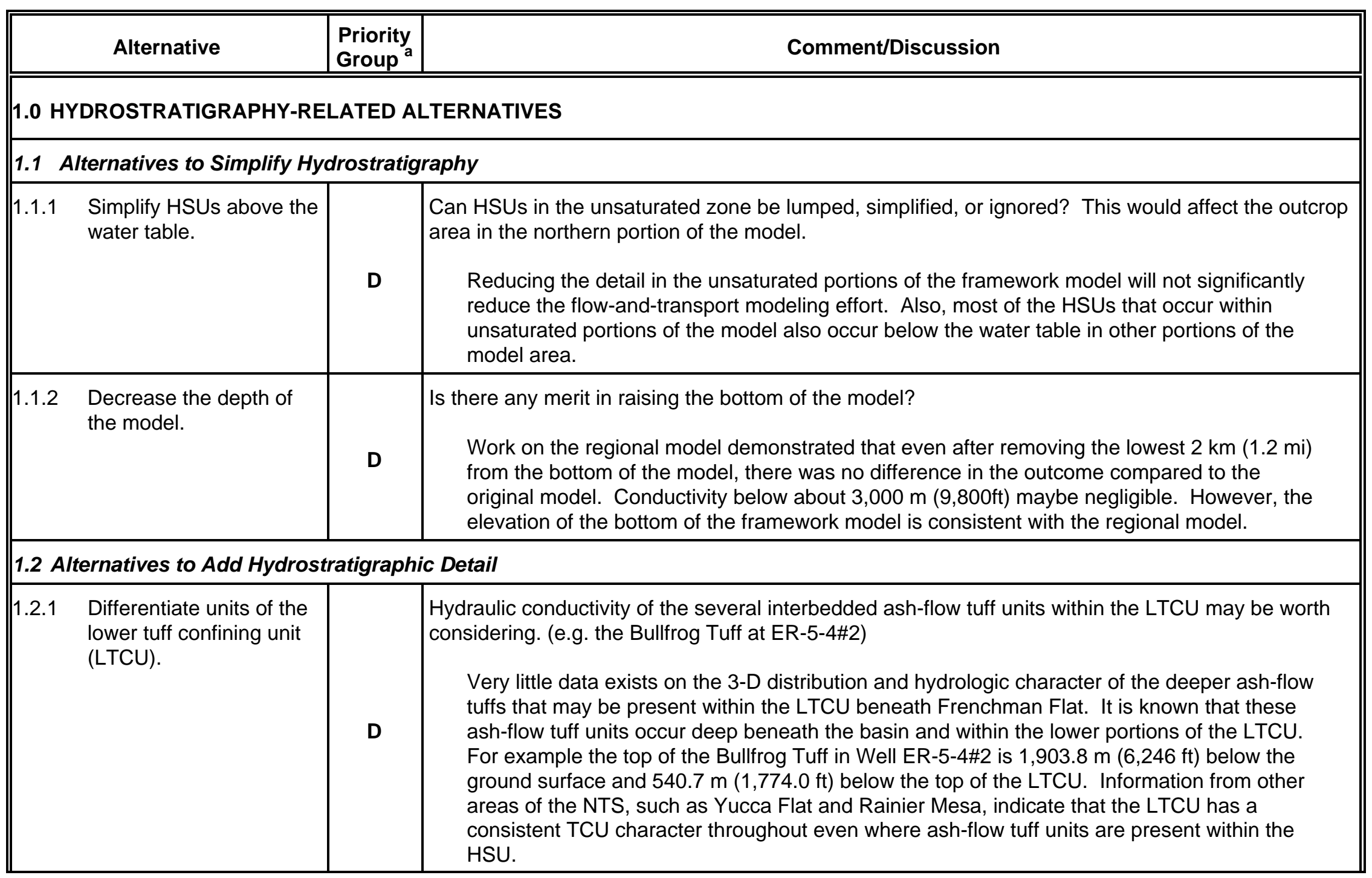


Table 5-1

Abridged List of Alternate Scenarios for the Frenchman Flat 3-D Hydrostratigraphic Model (continued)

\begin{tabular}{|c|c|c|c|}
\hline & Alternative & $\begin{array}{l}\text { Priority } \\
\text { Group a }\end{array}$ & Comment/Discussion \\
\hline $\mid 1.2 .2$ & $\begin{array}{l}\text { Subdivide the alluvium } \\
\text { based on relative } \\
\text { abundance of reactive } \\
\text { minerals. }\end{array}$ & A & $\begin{array}{l}\text { Is there enough information (e.g. in Warren et al., 2002), and are the differences significant and/or } \\
\text { predictable enough to warrant subdividing these units? Perhaps this should be a separate sub-CAU- } \\
\text { scale model. } \\
\text { Information from Warren et al. (2002) and Pawloski (1996) indicate significant differences in } \\
\text { the mineralogical and physical properties of the alluvium within Frenchman Flat that likely } \\
\text { affect significantly groundwater flow and contaminate transport within the model area. } \\
\text { Because much of the alluvium is saturated in Frenchman Flat, and } 9 \text { of the } 10 \text { underground } \\
\text { nuclear tests conducted in Frenchman Flat were detonated within the alluvium, it is } \\
\text { important to model as much detail as possible within the alluvium section. }\end{array}$ \\
\hline $\mid 1.2 .3$ & $\begin{array}{l}\text { Subdivide the } \\
\text { volcaniclastic confining } \\
\text { unit (VCU) in the } \\
\text { southern portion of the } \\
\text { model. }\end{array}$ & C & $\begin{array}{l}\text { Though dominated by fine-grained clastic rocks and zeolitic tuff, the VCU also includes lenses of } \\
\text { gravel and thin freshwater carbonate beds where it outcrops in the southern portion of Frenchman } \\
\text { Flat. Beneath the basin, however, very little is known about this HSU. The deep occurrence of this } \\
\text { HSU below thick LTCU within much of the basin likely reduces the hydrologic significance of any } \\
\text { aquifer-like rocks intercalated within the HSU. } \\
\text { The unit could be subdivided in a conceptual manner by varying hydrologic parameters } \\
\text { during flow-and-transport modeling to approximate the occurrence of more aquifer-like rocks } \\
\text { within the unit. }\end{array}$ \\
\hline $\mid 1.2 .4$ & $\begin{array}{l}\text { Maximize detail within } \\
1,000 \mathrm{~m}(3,280 \mathrm{ft}) \text { of the } \\
\text { water table. }\end{array}$ & D & $\begin{array}{l}\text { Will small differences at, or just beneath the water table make significant differences in the flow-and- } \\
\text { transport modeling results (e.g., raise or lower an HSU, or, add or remove HSUs)? } \\
\text { The subdivision of the alluvium as discussed in } 1.2 .2 \text { above will accomplish this in much of } \\
\text { the model area. }\end{array}$ \\
\hline
\end{tabular}


Table 5-1

Abridged List of Alternate Scenarios for the Frenchman Flat 3-D Hydrostratigraphic Model (continued)

\begin{tabular}{|c|c|c|c|}
\hline & Alternative & $\begin{array}{l}\text { Priority } \\
\text { Group }^{\text {a }}\end{array}$ & Comment/Discussion \\
\hline $\begin{array}{l}1.2 .5 \\
\mathrm{~N} \\
\mathrm{~W} \\
\mathrm{al} \\
\mathrm{in} \\
\mathrm{ut} \\
\mathrm{m}\end{array}$ & $\begin{array}{l}\text { Basalt-flow geometry. } \\
\text { te: Interpretation a) } \\
\text { s designated the } \\
\text { rnative and } \\
\text { rpretation b) was } \\
\text { ized in the base } \\
\text { del. }\end{array}$ & A & $\begin{array}{l}\text { a) Model the basalt as a continuous unit from Well Cluster ER-5-3 to the basin-forming faults to the } \\
\text { east (Alternative \#1; see Section 5.2.1). } \\
\text { Although surface magnetic data suggest that the basalt beneath northern Frenchman } \\
\text { Flat is not a continuous flow, uncertainty associated with magnetic data allow for the } \\
\text { possibility that the basalt is continuous. } \\
\text { b) Model the basalt as if dissected by erosion, faulted, or composed of separate lobes. } \\
\text { Surface magnetic data indicate that the basalt consists of several separate occurrences. } \\
\text { c) How would a basalt dike affect groundwater flow? What properties should be assigned to this } \\
\text { material? Can we define the hydrologic properties of such a thin tabular body? } \\
\text { A basalt dike would likely have hydrologic properties similar to a basalt lava-flow aquifer. } \\
\text { There is no evidence that basaltic dikes occur beneath Frenchman Flat, and thus the } \\
\text { locations and geometries of any such features is completely unknown. }\end{array}$ \\
\hline \multicolumn{4}{|c|}{ 1.3 Alternatives Addressing Different Distributions for Pre-Tertiary HSUs } \\
\hline 1.3 .1 & $\begin{array}{l}\text { Change the HSU } \\
\text { designation for the } \\
\text { Paleozoic carbonate } \\
\text { rocks exposed around } \\
\text { the margins of the basin } \\
\text { (LCA or LCA3?). }\end{array}$ & D & $\begin{array}{l}\text { These outcrops are currently modeled as LCA. Could they be LCA3? } \\
\text { Published maps and reports indicate that carbonate rocks exposed around the margins of } \\
\text { Frenchman Flat are part of a thick continuous carbonate sequence. Thrust faults are } \\
\text { present southeast of the model area, suggesting that the carbonate rocks around the } \\
\text { margins of the basin may be part of a thrust sheet. However, the thrust sheet would likely } \\
\text { be very thick, based on surface exposures, and the base of the thrust sheet would occur at } \\
\text { great depths below the basin. Thus it would likely have little hydrologic impact if the } \\
\text { carbonate rocks around the margins of Frenchman Flat basin are designated LCA or LCA3. }\end{array}$ \\
\hline
\end{tabular}


Table 5-1

Abridged List of Alternate Scenarios for the Frenchman Flat 3-D Hydrostratigraphic Model (continued)

\begin{tabular}{|c|c|c|}
\hline Alternative & $\begin{array}{l}\text { Priority } \\
\text { Group }^{\mathrm{a}}\end{array}$ & Comment/Discussion \\
\hline 1.3.2 Subdivide the LCA. & D & $\begin{array}{l}\text { Would occurrences of the Dunderberg Shale or Eureka Quartzite alter flow in the LCA? } \\
\text { The LCA, which is approximately 4,267 } \mathrm{m} \text { ( } 14,000 \mathrm{ft}) \text { thick, consists mainly of massive } \\
\text { carbonate. However, siliciclastic units, such as the Dunderberg Shale and Eureka Quartzite, } \\
\text { occur within the LCA. These units are generally less than } 91 \mathrm{~m} \text { ( } 300 \mathrm{ft} \text { ) thick each and thus } \\
\text { account for less than } 5 \text { percent of the HSU. Few holes within the model area have } \\
\text { encountered the LCA and none have encountered the Dunderberg Shale or Eureka } \\
\text { Quartzite. Thus the 3-D distribution of these minor clastic units is unknown within most of } \\
\text { the model area. }\end{array}$ \\
\hline \multicolumn{3}{|c|}{ |2.0 STRUCTURE-RELATED ALTERNATIVES } \\
\hline $\begin{array}{l}\text { 2.1 Simplify the Structural } \\
\text { Model }\end{array}$ & D & $\begin{array}{l}\text { Omit all but the most profound structures and faults. } \\
\text { The number of faults and structural detail in the model are sufficient, and any simplification } \\
\text { of the structure will not significantly reduce future modeling efforts. In addition, the level of } \\
\text { structural detail in the framework model already represents a considerable simplification of } \\
\text { the structural geology of the area. Any further simplification may detrimentally affect the } \\
\text { integrity of the model. }\end{array}$ \\
\hline $\begin{array}{l}2.2 \text { Remove Faults Along Edge } \\
\text { of Model }\end{array}$ & D & $\begin{array}{l}\text { Remove faults in the southeast corner of the model. } \\
\text { Although removing faults might simplify flow-and-transport modeling, these faults define the } \\
\text { structural fabric of the area which is likely important with regards to groundwater flow, } \\
\text { particularly is direction. }\end{array}$ \\
\hline \multicolumn{3}{|l|}{ 2.3 Add More Structural Detail } \\
\hline 2.3.1 Add width to faults. & C & $\begin{array}{l}\text { Modify faults from simple two-dimensional surfaces to 3-D features having some width. } \\
\text { Flow-and-transport modeling might be used to explore whether this will help predict where } \\
\text { and why faults might be a barrier or conduit to groundwater flow. }\end{array}$ \\
\hline
\end{tabular}


Table 5-1

Abridged List of Alternate Scenarios for the Frenchman Flat 3-D Hydrostratigraphic Model (continued)

\begin{tabular}{|c|c|c|c|}
\hline & Alternative & $\begin{array}{l}\text { Priority } \\
\text { Group }^{\text {a }}\end{array}$ & Comment/Discussion \\
\hline 2.3 .2 & $\begin{array}{l}\text { Add more Tertiary faults } \\
\text { or fault zones. }\end{array}$ & D & $\begin{array}{l}\text { Perhaps begin by adding more of the mapped faults (shown on Slate et al. [1999] or the individual } \\
\text { USGS quadrangle maps). } \\
\text { The number of faults in the model is sufficient and a good compromise between geologic } \\
\text { reality and flow and transport modeling constraints. }\end{array}$ \\
\hline $\mid 2.3 .3$ & $\begin{array}{l}\text { Extend the CP thrust } \\
\text { fault south of the Cane } \\
\text { Spring fault. }\end{array}$ & D & $\begin{array}{l}\text { The CP thrust is a poorly characterized, west-to-northwest-vergent thrust fault, that appears to be } \\
\text { mostly outside the boundaries of the model area. Do we really need to add this complexity to the } \\
\text { northwest corner of the model? Could the fault be elsewhere, too? } \\
\text { The CP thrust is exposed at the surface just northwest of the model area where it places carbonate } \\
\text { rocks over siliciclastic rocks. The fault likely extends at depth into the model area beneath CP Basin } \\
\text { and is included in the model within this area. Resistivity data seem to show that the CP thrust fault } \\
\text { may be rooted within the steeply-dipping Cane Spring fault which bounds CP basin on southeast. } \\
\text { This is consistent with evidence from Yucca Flat that suggests the CP thrust dips steeply into the } \\
\text { Topgallant/Carpetbag fault system. Drilling and resistivity data from northern Frenchman Flat and } \\
\text { southern Yucca Flat indicate that the pre-Tertiary surface in these areas consists of carbonate rocks, } \\
\text { and magnetotelluric (MT) data indicate that the carbonate rocks extend to great depths just } \\
\text { southeast of the Cane Spring fault. Thus, if the CP thrust extends beyond the Cane Spring fault and } \\
\text { into the northwestern portion of Frenchman Flat it is either very deep or places carbonate rocks over } \\
\text { carbonate rocks, and thus will likely have minimal hydrologic effect if present beneath Frenchman } \\
\text { Flat. }\end{array}$ \\
\hline 2.3.4 & $\begin{array}{l}\text { Explore fault-related } \\
\text { groundwater pathways. }\end{array}$ & B & $\begin{array}{l}\text { Increase or decrease fault displacements so aquifers are juxtaposed across faults. Deliberately } \\
\text { juxtapose aquifer units across faults. Candidates for such adjustments would include the basin- } \\
\text { forming faults in the east. (Alternative \#3; see Section 5.2.3) }\end{array}$ \\
\hline
\end{tabular}


Table 5-1

Abridged List of Alternate Scenarios for the Frenchman Flat 3-D Hydrostratigraphic Model (continued)

\begin{tabular}{|c|c|c|c|}
\hline & Alternative & $\begin{array}{l}\text { Priority } \\
\text { Group }^{\text {a }}\end{array}$ & Comment/Discussion \\
\hline \multirow[t]{3}{*}{ |2.3.5 } & $\begin{array}{l}\text { Explore variations of the } \\
\text { CP thrust fault in } \mathrm{CP} \\
\text { Basin }\end{array}$ & & $\begin{array}{l}\text { The Cane Spring fault forms the southeast boundary of CP Basin. The fault seems to end abruptly } \\
\text { at the Massachusetts Mountain/CP Hogback juncture. The fault termination geometry may influence } \\
\text { deep inter-basin flow from Yucca Flat. }\end{array}$ \\
\hline & $\begin{array}{l}\text { Note: Interpretation a) } \\
\text { was used as the } \\
\text { alternative, and } \\
\text { interpretation b) was }\end{array}$ & B & $\begin{array}{l}\text { a) The MT data suggest that the UCCU is limited in extent in this area, so the scenario of a } \\
\text { continuous thrust sheet of UCCU beneath the CP Basin is modeled as an alternative. } \\
\text { (Alternative \#4; see Section 5.2.4) }\end{array}$ \\
\hline & $\begin{array}{l}\text { integrated into the base } \\
\text { model. }\end{array}$ & A & $\begin{array}{l}\text { b) The pre-Tertiary structure (e.g. the CP thrust) beneath CP basin based mainly on the results of } \\
\text { the MT survey, which limits the extent of the UCCU beneath the CP Basin. Also, the Cane } \\
\text { Spring fault is modeled as terminating in an imbricate fan similar to the Rock Valley fault system. }\end{array}$ \\
\hline \multirow[t]{2}{*}{2.3 .6} & Other fault variations & & Faults are depicted in the hydrostratigraphic framework model as single planes. \\
\hline & & $\mathbf{C}$ & $\begin{array}{l}\text { Explore through flow-and-transport modeling, if warranted, whether there would be } \\
\text { hydrologic consequences if the faults are zones consisting of multiple parallel individual fault } \\
\text { planes. }\end{array}$ \\
\hline \multicolumn{4}{|c|}{ 2.4 Develop Different Structural Scenarios } \\
\hline \multirow[t]{2}{*}{$\mid$} & Vary fault dips. & C & $\begin{array}{l}\text { The basin-and-range normal faults are modeled using a 75-degree dip. Varying fault dips would } \\
\text { present more consequences in the source areas, where fault proximity to working points is } \\
\text { important. }\end{array}$ \\
\hline & & & This might be better addressed in sub-CAU-scale hydrologic models. \\
\hline \multirow[t]{2}{*}{2.4 .2} & $\begin{array}{l}\text { Vary the depth to } \\
\text { basement rocks. }\end{array}$ & \multirow[b]{2}{*}{ D } & $\begin{array}{l}\text { The uncertainty in depth to basement based on geophysical data (gravity) is roughly } 300 \mathrm{~m}(1,000 \mathrm{ft}) \\
\text { in places. This may not be geologically permissible in some areas. And where it is possible, what } \\
\text { units would be thinned or thickened? }\end{array}$ \\
\hline & & & $\begin{array}{l}\text { Although some data, such as gravity, have relatively low resolution, other data sets } \\
\text { particularly the most recent data such as deep drilling and 3-D seismic are higher resolution } \\
\text { and constrain the depth to basin fairly well in the hydrologically significant areas such as the } \\
\text { northern and central portions of Frenchman Flat. }\end{array}$ \\
\hline
\end{tabular}


Table 5-1

Abridged List of Alternate Scenarios for the Frenchman Flat 3-D Hydrostratigraphic Model (continued)

\begin{tabular}{|c|c|c|c|}
\hline & Alternative & $\begin{array}{l}\text { Priority } \\
\text { Group }^{\text {a }}\end{array}$ & Comment/Discussion \\
\hline || 2.4 .3 & $\begin{array}{l}\text { Vary the geometryl } \\
\text { position of the Rock } \\
\text { Valley fault. }\end{array}$ & D & $\begin{array}{l}\text { This northeast-southwest striking strike-slip fault is intimately related to basin formation. Does it also } \\
\text { control groundwater flow out of Frenchman Flat? } \\
\text { The location and general geometry of this fault zone are relatively well constrained. }\end{array}$ \\
\hline || 2.4 .4 & $\begin{array}{l}\text { Vary displacement on } \\
\text { basin-forming faults. }\end{array}$ & D & $\begin{array}{l}\text { Distribute displacements along basin-forming faults along east side to better fit gravity data. } \\
\text { The distribution of displacement along basin-forming faults matches relatively well with the } \\
\text { gravity data, particularly considering the low resolution typically associated with gravity data. } \\
\text { However, some fault displacements were varied as part of Alternative \#3 (2.3.4) to juxtapose } \\
\text { aquifers. }\end{array}$ \\
\hline \multicolumn{4}{|c|}{ 2.5 Other Structure-Related Alternatives } \\
\hline $\mid 2.5 .1$ & $\begin{array}{l}\text { "Smooth" versus "rough" } \\
\text { HSU surface. }\end{array}$ & D & $\begin{array}{l}\text { Computer idiosyncracies have produced "hills" and "indentations" on HSU surfaces where none } \\
\text { were intended. Does it matter? A rough surface might better approximate the effect of faulting. } \\
\text { The elevations of the "hills" and "indentations" are not great enough to be significant. }\end{array}$ \\
\hline 2.5 .2 & $\begin{array}{l}\text { Consider defining basin } \\
\text { slopes with faults. }\end{array}$ & D & $\begin{array}{l}\text { The UGTA base model portrays many of the central basin gravity lows as syncline-type structures } \\
\text { and not half-grabens (e.g. northeast of the Well Cluster ER-5-4). Are there more faults (possibly } \\
\text { hydrologically significant) that are not discernable with geophysics? } \\
\text { The overall shape of the central portion of the basin is a half-graben. The apparent synclinal } \\
\text { shape is probably due to hanging wall drag along the large basin-forming faults. There are } \\
\text { certainly more faults, however geophysical data (e.g. seismic and gravity) constrain } \\
\text { additional faults as relatively small displacement. No large host blocks are observed within } \\
\text { the central portion of the basin. }\end{array}$ \\
\hline $\mid 2.5 .3$ & $\begin{array}{l}\text { Explore variations of the } \\
\text { accommodation zone } \\
\text { between Frenchman and } \\
\text { Yucca Flat. }\end{array}$ & D & $\begin{array}{l}\text { This feature appears as a gravity high between two extensional basins. How does this area affect } \\
\text { inter-basin groundwater flow? } \\
\text { Although this area is complex, surface exposure is very good, and geophysical data are } \\
\text { available for much of the area. The base model incorporates these data, including HSU } \\
\text { contacts and faults exposed at the surface, and thus models the most important controls } \\
\text { such as HSU distribution and fault orienations fairly well in this area. }\end{array}$ \\
\hline
\end{tabular}


Table 5-1

Abridged List of Alternate Scenarios for the Frenchman Flat 3-D Hydrostratigraphic Model (continued)

\begin{tabular}{||l|c|c||}
\hline \hline Alternative & $\begin{array}{c}\text { Priority } \\
\text { Group a }\end{array}$ & Comment/Discussion \\
\hline \hline $2.5 .4 \begin{array}{l}\text { Remove the detachment } \\
\text { fault. }\end{array}$ & B & $\begin{array}{l}\text { Model volcanic rocks in the northern portion of basin as moderately dipping surfaces to the south } \\
\text { (Alternative \#2; see Section 5.2.2). }\end{array}$ \\
\hline
\end{tabular}

a Group A are changes to the UGTA hydrostratigraphic framework base model recommended by the alternative scenario working group, and are already implemented.

Group B are considered viable alternative scenarios that will be modeled. See Section 5.2.

Group $\mathbf{C}$ are proposed alternatives that will be further evaluated during flow and transport modeling, if necessary, by manipulating parameter values, and are not addressed as alternatives to the hydrostratigraphic framework model.

Group $\mathbf{D}$ are proposed alternatives that were deemed to be low priority (due to perceived minimal consequences to groundwater flow and contaminant transport), not cost-effective, not practical (no data, too complex, etc.), or simply not necessary to model at this time.

Note: Earlier drafts of this table included a section on hydrologic alternatives. None of the listed hydrologic scenarios could be addressed in the hydrostratigraphic framework model, so they have been removed from this version of the table. 
will be addressed during flow and transport modeling by manipulation of model parameters. Thus, separate alternative framework models were not developed for these ideas.

Category D alternatives were deemed not significant or viable enough to warrant development as alternative models. These alternative ideas will not be considered further.

The changes listed in Group A listed below were implemented and are part of the base model as reported in this document.

\section{Group A - Changes Made in the Base Model}

(Numbers in parentheses refer to Table 5-1, where more information about these changes can be found.)

1. Subdivide the alluvial section (1.2.2).

2. Portray the basalt lava-flow aquifer as smaller and discontinuous flows (1.2.5).

3. Model the pre-Tertiary structure (e.g., the CP thrust fault) based mainly on MT data, and terminate the Cane Spring fault in a imbricated fan as conceptualized for the Rock Valley fault system (2.3.5).

The short list of alternative scenarios which the working group deemed important enough to pursue (Group B) are listed below.

\section{Group B - Viable Alternative Scenarios}

Numbers in parentheses refer to Table 5-1, where more information about these changes can be found. See also discussion of each alternative in Section 5.2

1. Portray the basalt HSU as a single, extensive, continuous lava flow (1.2.5).

2. Remove the detachment fault and portray volcanic rocks as moderately dipping surface (2.5.3).

3. Explore fault-related groundwater pathways. Vary displacement of the basinforming faults to force juxtaposition of HSUs (2.3.4).

4. Explore variations in structural geometry for the CP Basin. Model UCCU as a continuous thrust sheet (2.3.5). 
Proposed alternatives that would be better addressed, if deemed necessary, during the hydrologic modeling phase rather than as alternatives to the geologic framework model make up Group C. These alternatives might best be handled by various methods of generating flow model grids and assigning different hydraulic properties to faults or HSUs, rather than changing the framework model or building a separate model.

\section{Group C - Proposed Alternatives to Address During the Hydrologic Modeling Phase}

(Numbers in parentheses refer to Table 5-1, where more information about these changes can be found.)

1. Subdivide the volcaniclastic confining unit (VCU) (1.2.3).

2. Add width to fault planes (2.3.1).

3. Fault variations such as faults composed of parallel multiple planes (2.3.6).

4. Vary fault dips near source areas (2.4.1).

\subsection{Alternative Models}

This section describes the four alternative models developed for the Frenchman Flat hydrostratigraphic framework model.

\subsubsection{Portray the Basalt as a Single, Continuous Lava Flow (Alternative \#1)}

The Frenchman Flat base model depicts the BLFA as three separate and discontinuous bodies embedded within the alluvial section (Figure 4-8). This geometry is based on drill hole and ground magnetic data (Section 4.3.4). However, there is some uncertainty associated with this interpretation. It is not known if these are three separate flows or erosional remnants of a single larger flow. Also, aeromagnetic and ground magnetic data do not extend far enough east to show definitively the eastern limit of the BLFA. Coincidently, the BLFA is located at or near the water table. The presence and geometry of such an aquifer near the water table may affect flow and transport of radionuclides away from underground nuclear tests in the vicinity.

Furthermore, the source of this BLFA is not known. Several of the basalt flows and dikes to the north in the Half Pint Range are associated with generally north-south trending faults (Hinrichs et al., 1965; Byers and Barnes, 1967). It is conceivable that one of the basin-forming faults in the Frenchman Flat model is the source for the Frenchman Flat basalt. If so, the BLFA could possibly provide a lateral conduit for contaminants from underground nuclear tests in northern Frenchman Flat eastward to the fault and ultimately to the LCA. This alternative will allow flow-and-transport modeling to explore the consequences of a contiguous basalt lave-flow 
aquifer near the water table in the vicinity of the group of underground nuclear tests in northern Frenchman Flat. A comparison of the BLFA in the base model and in alternative scenario \#1 is shown in Figure 5-1.

\subsubsection{Remove the Detachment Fault (Alternative \#2)}

Drill hole and 3-D seismic data suggest that a detachment fault is present beneath the northern portion of Frenchman Flat (see Section 3.2.3 and Appendix D), and this interpretation was included in the base model. However, because of the uncertainty of this interpretation and the potential hydrologic consequences associated with such an interpretation, an alternative model was developed that did not include the detachment fault. In the alternative model, the detachment fault is removed, and volcanic rocks are modeled as dipping moderately southward from borehole UE-11b and nearby surface exposures to the deeper intercepts in drill holes located to the south (Figure 5-2).

\subsubsection{Juxtaposition of HSUs Along Faults (Alternative \#3)}

Because basin-forming faults typically have large vertical displacements, the juxtaposition of shallow aquifers against deeper aquifers could occur and be significant with regard to flow-andtransport modeling in the Frenchman Flat area. In the base hydrostratigraphic framework model, no aquifers are juxtaposed due to faulting along the main basin-forming faults. However, the locations, orientations and amounts of displacements associates with these faults is poorly constrained. Therefore an alternative model was developed that juxtaposed shallow volcanic aquifer HSUs with the LCA along a major basin-forming fault (Figures 5-3a and 5-3b).

\subsubsection{Variations of the CP Thrust Fault in CP Basin (Alternative \#4)}

Considerable uncertainty exists with regard to the pre-Tertiary structural geology beneath CP Basin. Consequently, the distribution of pre-Tertiary HSUs beneath the basin is poorly known, particularly the distribution of the UCCU. The UCCU is exposed in the footwall of the CP thrust fault just northwest of the model area, and MT recordings seem to indicate that the UCCU is present beneath the northeastern portion of CP Basin. The base model incorporates the MT data, and thus places the UCCU beneath CP Basin as part of the footwall of the CP thrust, and limits its extent to the northeastern portion of the basin. Overlying the footwall rocks is a continuous sheet of carbonate rocks that composes the hanging wall of the CP thrust.

Because of the uncertainties associated with the distribution of the UCCU beneath CP Basin, and the potential hydrologic influence of this major confining unit, particularly with regards to groundwater flux out of southern Yucca Flat and into the northwest portions of the model area, an alternative model was developed for CP Basin (Figure 5-4). The alternative model extends 
the UCCU beneath all of CP basin, resulting in a continuous sheet of UCCU beneath the basin. As in the base model, a continuous sheet of carbonate rock comprising the hanging wall of the CP Thrust overlies the UCCU beneath the basin. 
This page intentionally left blank. 


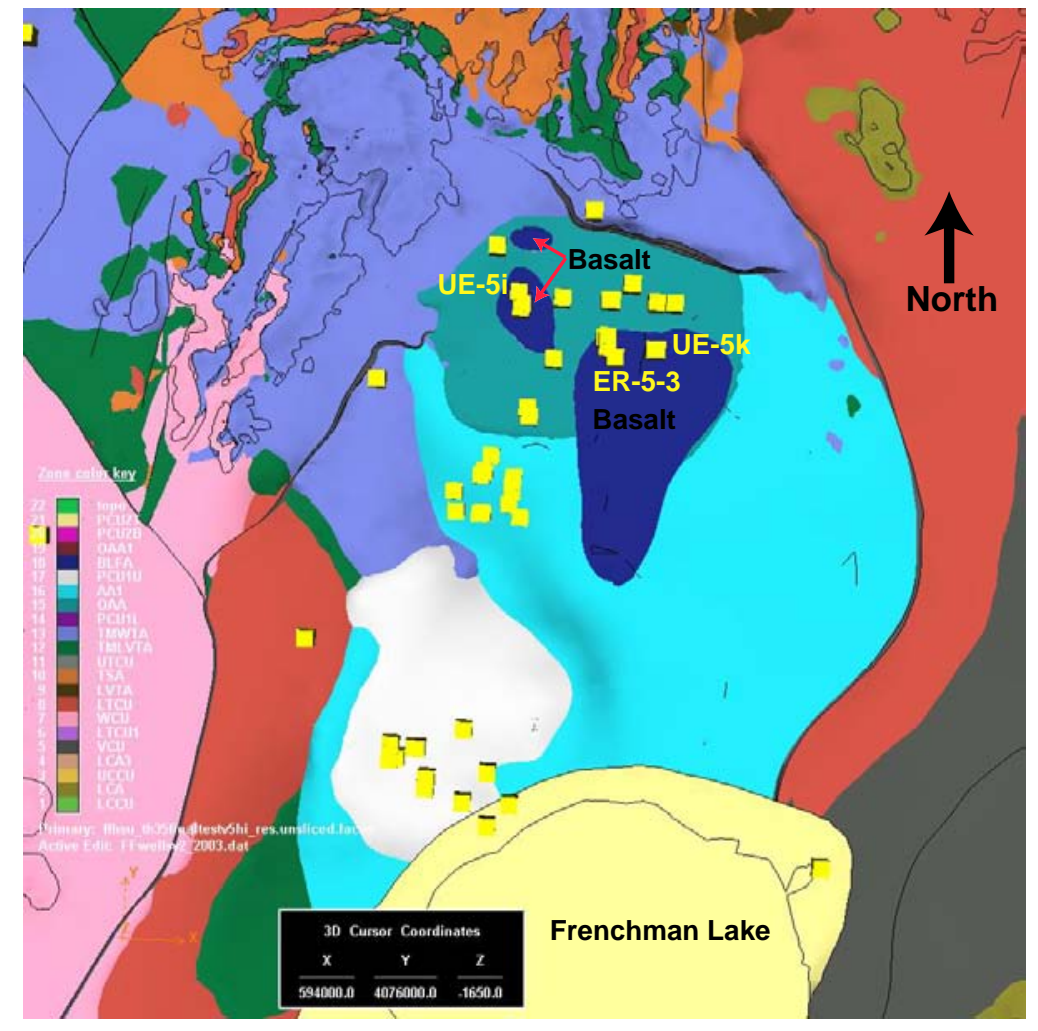

Extent of basalt in base model.

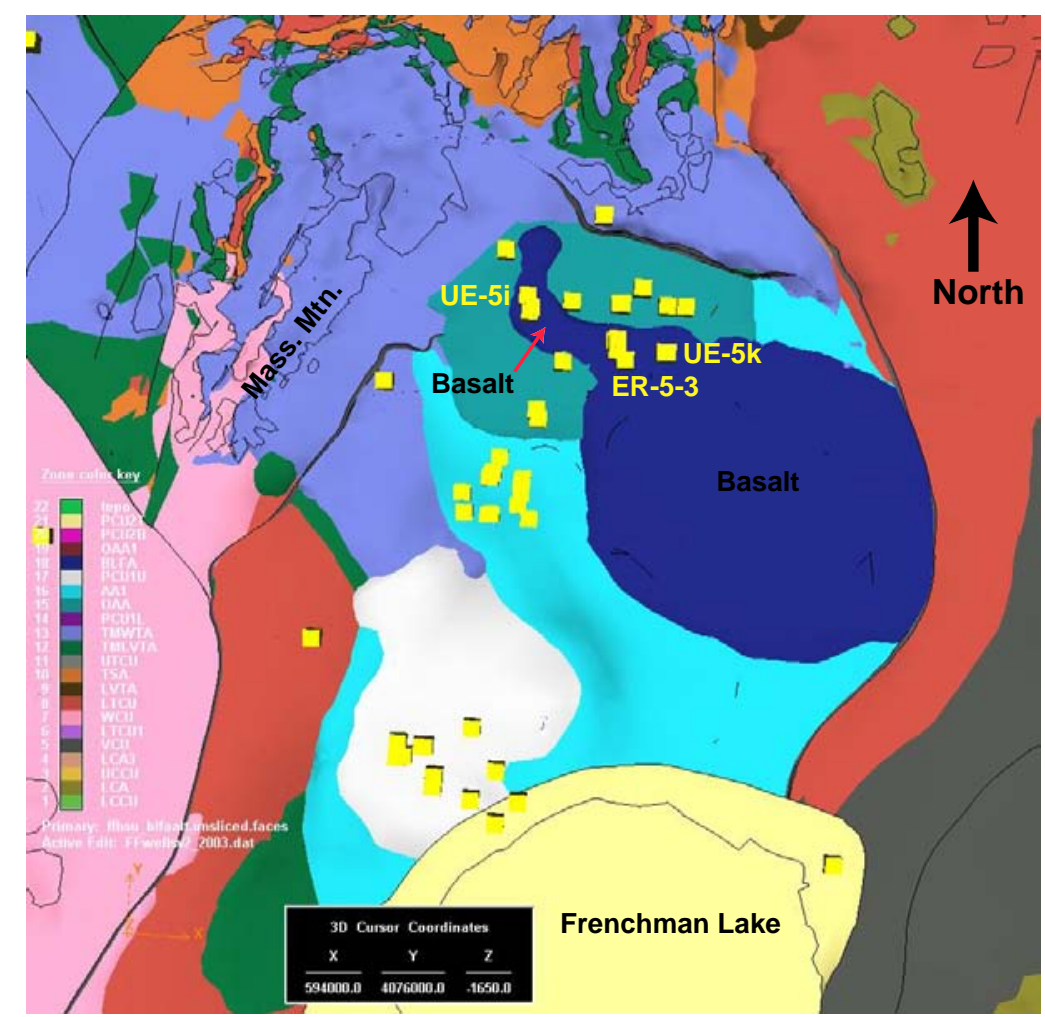

Extent of basalt in Alternative Scenario \#1.

Figure 5-1

Comparison of the Basalt Lava-Flow Aquifer in the Base Model with Alternative Scenario \#1. 
Base Model with Detachment Fault

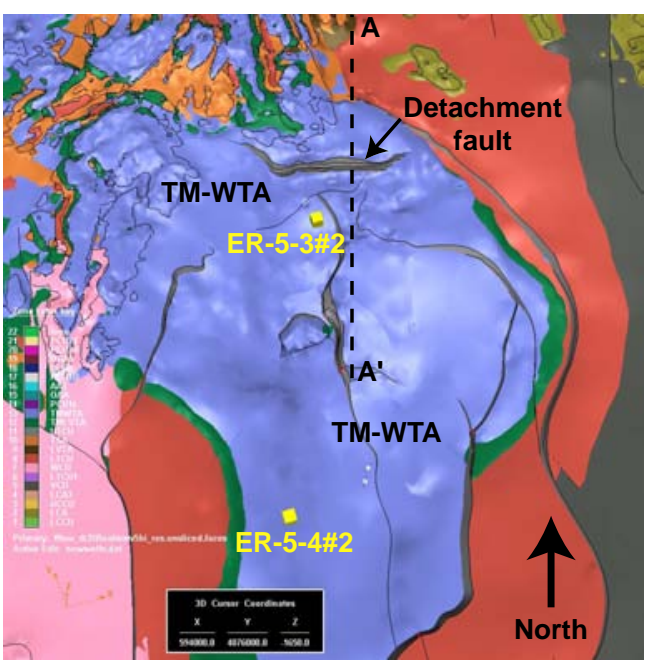

Map view of EarthVision model with alluvial, playa, and basalt HSUs removed.

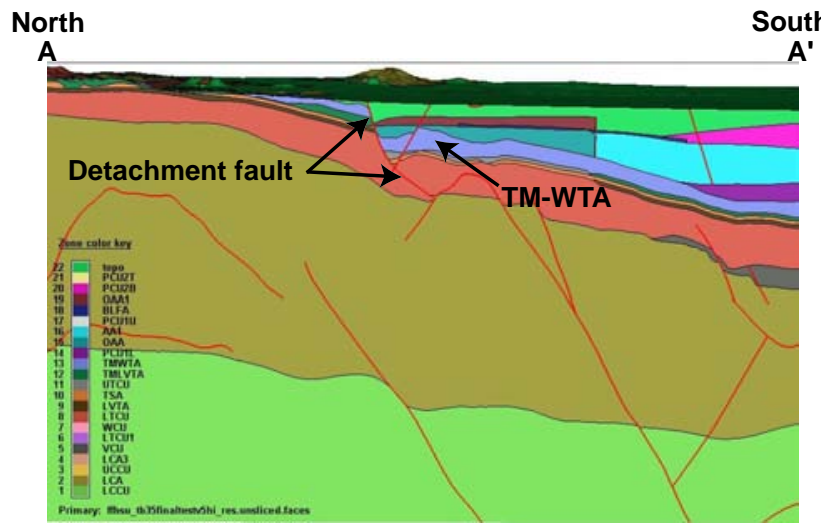

North-south profile showing detachment fault in base model.

\section{Alternative \#2 without Detachment fault}

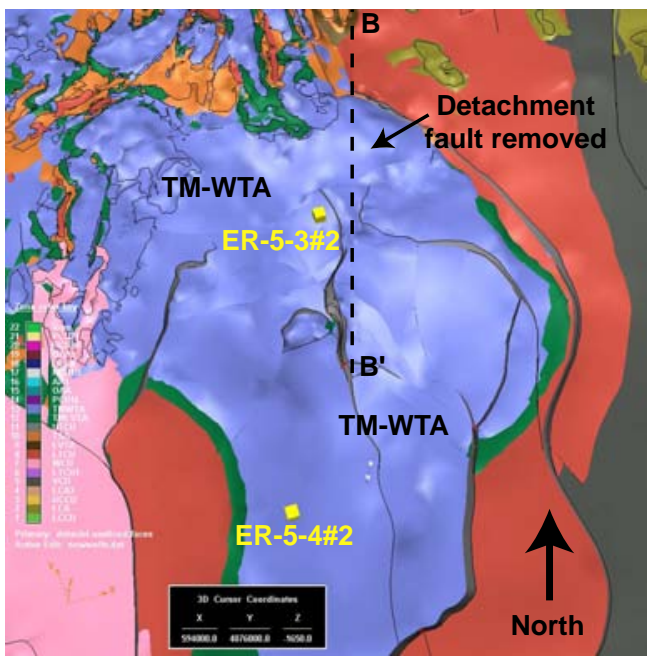

Map view of EarthVision model

with alluvial, playa, and basalt HSUs removed.

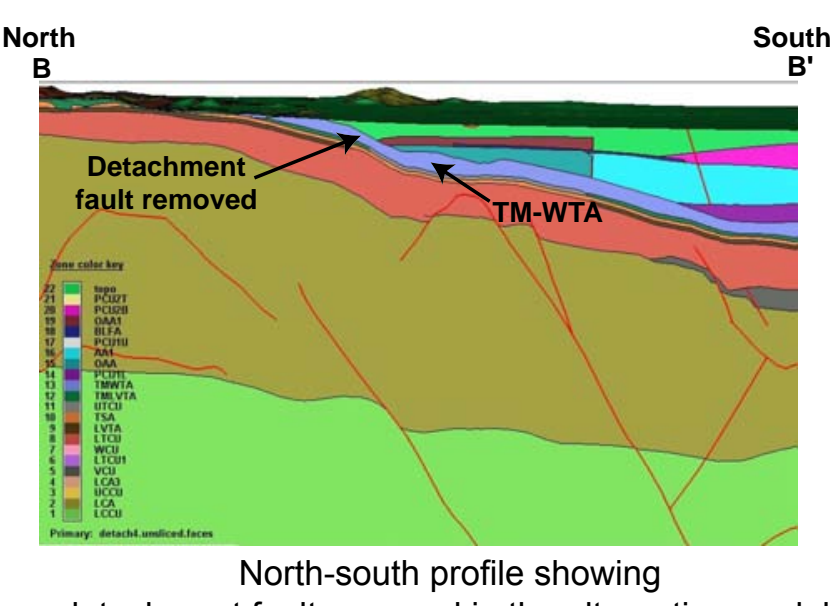

detachment fault removed in the alternative model.

Figure 5-2

Comparison of the Base Model with the No Detachment Fault Alternative (Alternative \#2). 


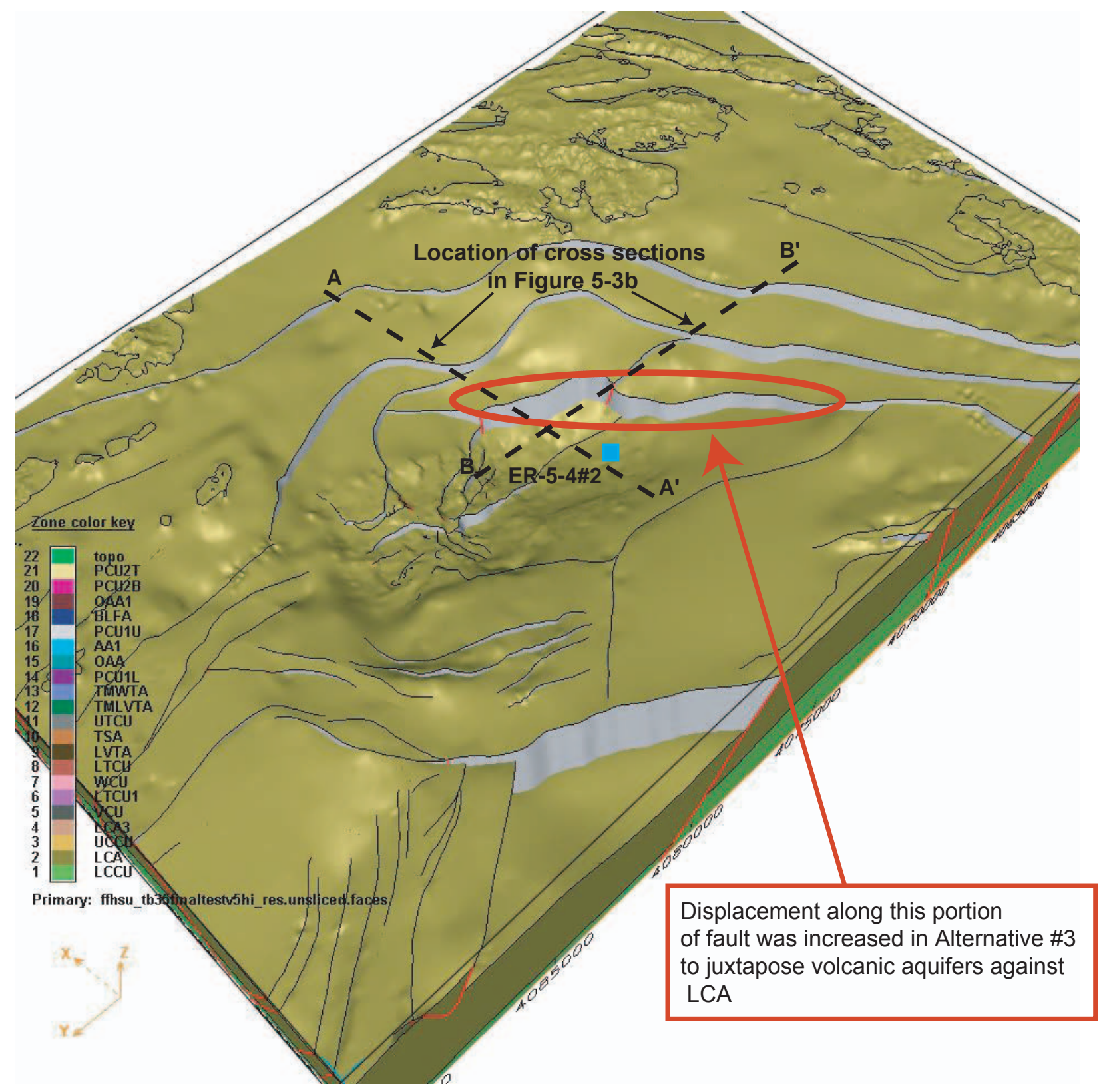

Figure 5-3a

Perspective View of the Base Model Showing

Top of LCA and Location of Alternative \#3

(View is Southeast) 


\section{Base Model}

No aquifers in contact with LCA along fault
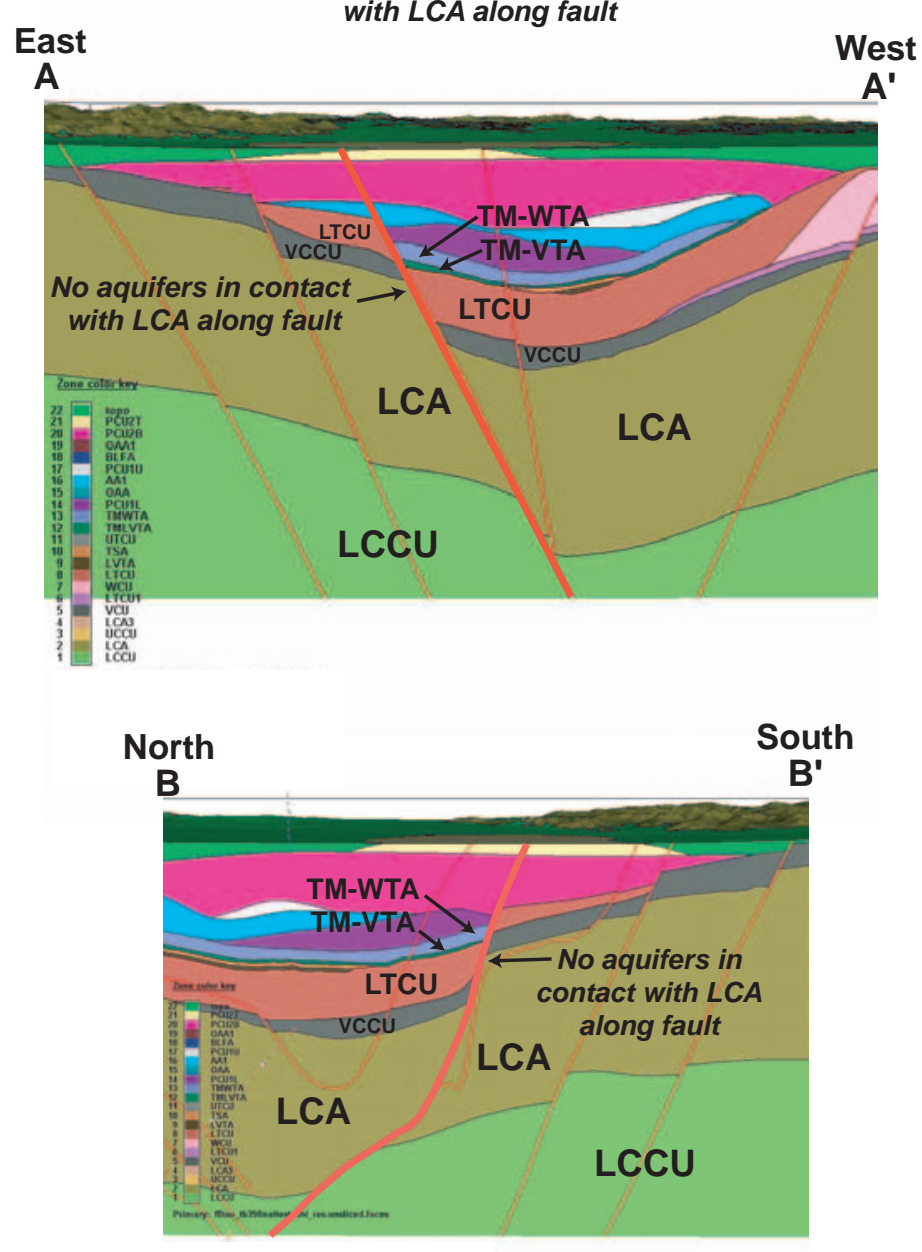

\section{Alternative \#3}

Volcanic aquifers in contact

with LCA along fault

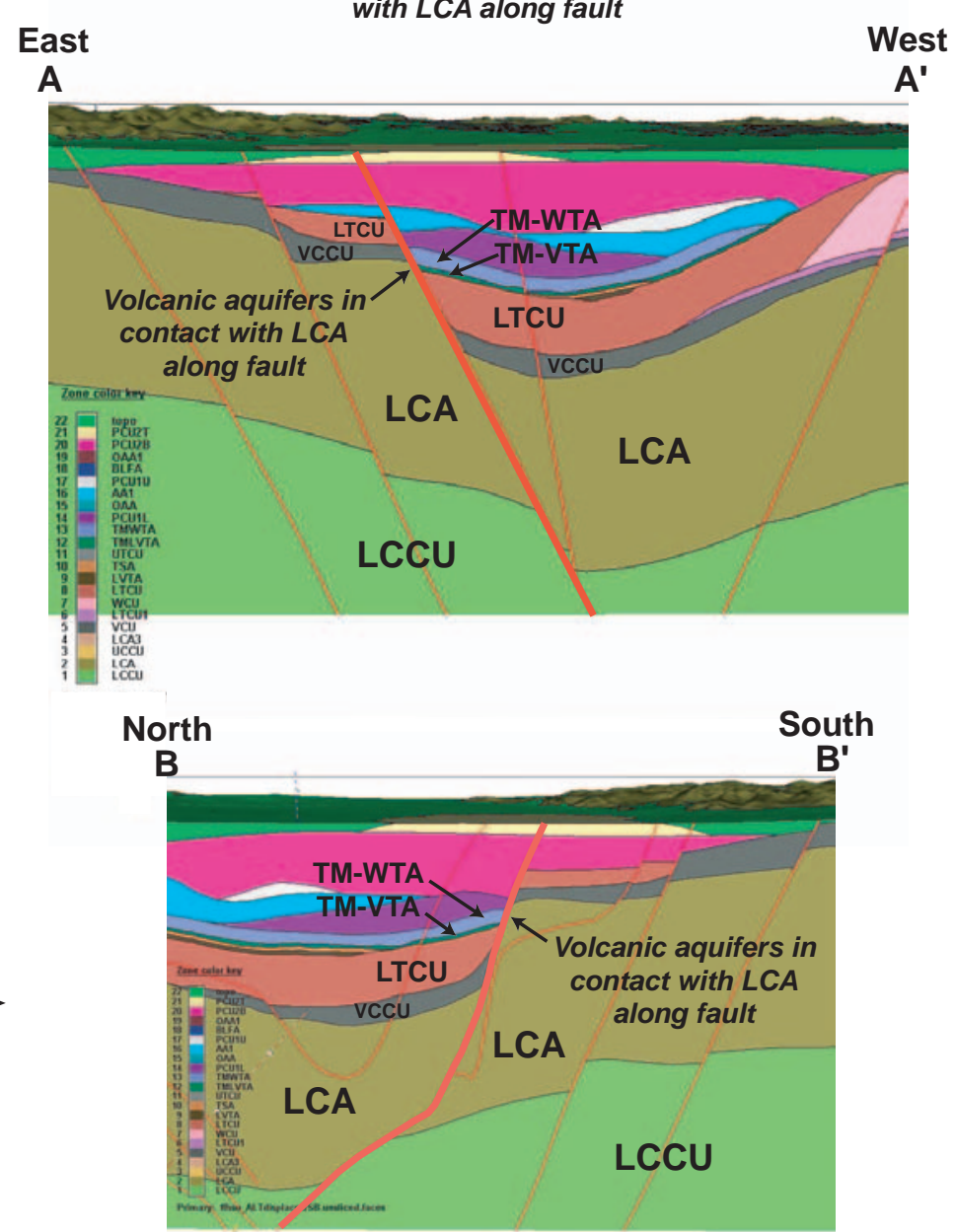

Figure 5-3b

Profiles Comparing Base Model with Alternative \#3 
Base model showing limited extent of UCCU beneath CP Basin

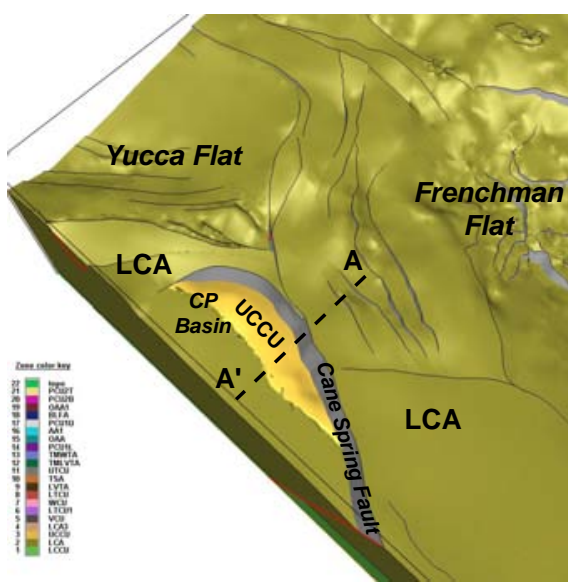

Perspective view of EarthVision model with LCA3 removed.

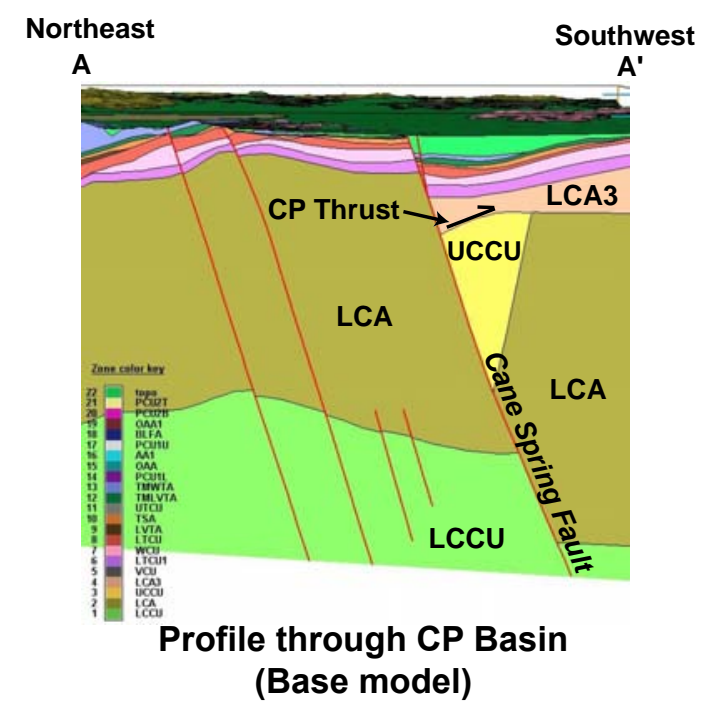

Alternative \#4 showing continuous sheet of UCCU beneath CP Basin
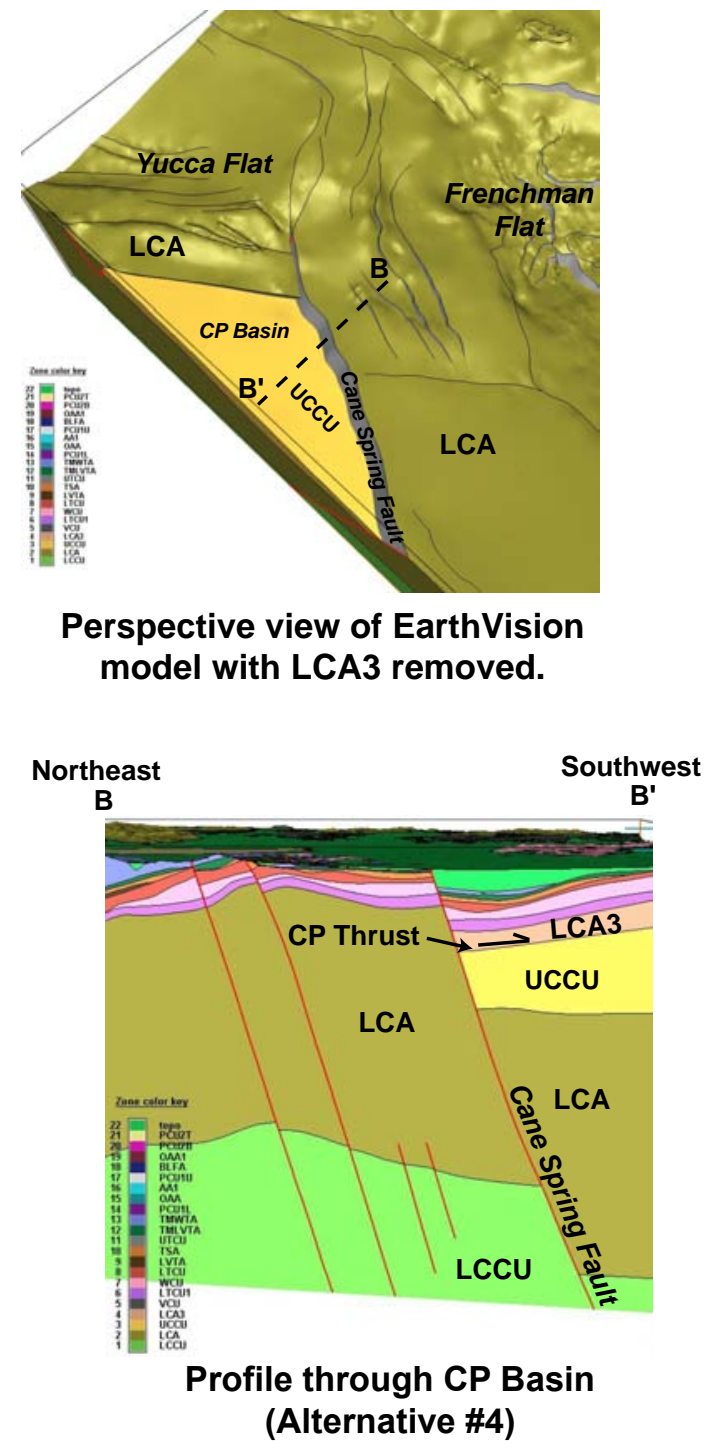

Figure 5-4

Comparison of the Base Model with the CP Basin Alternative (Alternative \#4) 


\subsection{SUMMARY}

Frenchman Flat, encompassing Areas 5 and 11 of the NTS (CAU 98), was the site of 10 underground nuclear tests. Because several of these tests were conducted near or below the water table, test-related contaminants are presumed available for transport via the groundwater flow system. Models are being developed by the UGTA Project of the NNSA/NSO Environmental Restoration Program to predict groundwater flow and contaminant transport from the source areas to groundwater discharge areas. The hydrologic modelers require a hydrostratigraphic framework that addresses the character and extent of geologic units in three dimensions. The development and description of this framework for the Frenchman Flat area is documented in this report.

The general hydrogeologic framework for the NTS and vicinity established by USGS geoscientists in the early 1970s, has provided the foundation for most subsequent hydrogeologic studies at the NTS, including the Frenchman Flat hydrostratigraphic model. The hydrostratigraphic framework for the Frenchman Flat area documented in this report is a product of several phases of work over several years supported by the UGTA Project, in which the hydrogeologic understanding of the model area has become increasingly detailed and refined as a result of the contributions of many people and organizations associated with the NTS.

The hydrogeology of the southeastern NTS, including Frenchman Flat, is complex. The thick sections of alluvium and volcanic rocks comprise a wide variety of lithologies that can range in hydraulic character from aquifer to aquitard. Basin and Range faulting have acted to further complicate the area, placing the various lithologic units in juxtaposition, and blocking or enhancing the flow of groundwater in a variety of ways.

In this study, earlier hydrogeologic framework models were integrated with drill-hole data (stratigraphic, lithologic, and alteration data), data from several geophysical, geological, and hydrological studies and a new conceptual structural model, to formulate a hydrostratigraphic classification system. Applying this updated understanding of Frenchman Flat area hydrogeology, the authors organized the volcanic units in the study area into 17 HSUs that include 9 aquifers, 8 confining units. In this model the alluvial section was subdivided into 5 HSUs including the alluvial aquifer, a basalt lava-flow aquifer, 2 playa confining units, and an older altered alluvium aquifer. The Tertiary volcanic rock section was subdivided into 7 HSU including 4 aquifers and 3 confining units. The older Tertiary-age sediments are lumped into a single confining unit HSU. The underlying pre-Tertiary rocks were divided into 4 HSUs, 
including 2 aquifers and 2 confining units. The drill-hole database was then converted to a hydrostratigraphic database based on this hydrostratigraphic classification system, and, along with the new conceptual structural model, provided the basis to construct unit-extent and structure-contour maps for each HSU. Three-dimensional surfaces were derived from these maps using the EarthVision ${ }^{\circledR}$ modeling software. The 3-D volumes defined by these surfaces will serve as layers for the UGTA groundwater modeling process.

To construct this model, the raw data compiled by SNJV and BN geologists, and interpretative products prepared by BN geologists (fault framework, cross sections, etc.) were input into EarthVision ${ }^{\circledR}$. SNJV personnel who are knowledgeable in the use of EarthVision ${ }^{\circledR}$ were responsible for building the digital 3-D model. The resultant model was reviewed and corrected as necessary by the authors in an iterative fashion, to resolve structural problems that tend to develop as a result of sparse data and the computerized model building process. The maps and profiles provided in this document are selected presentations from the digital model and are meant only to generally illustrate the character of the HSUs (model layers). This framework will be transmitted electronically in the form of an EarthVision ${ }^{\circledR}$ model that is directly usable by the hydrologic modelers.

The geologic complexity of the model area and sparse data for much of the region resulted in the incorporation of some non-unique interpretations into the base model. This made it necessary to address alternative interpretations for some of the major features in the model. Four of these alternatives were developed so they could be modeled in the same fashion as the base model, and are expected to aid the hydrologic modelers in exploring and refining the results of the flow and transport models. 


\subsection{REFERENCES}

Anderson, J. G., J. N. Brune, D. dePolo, J. Gomberg, S. C. Harmsen, M. K. Savage, A. K. Sheehan, and K. D. Smith, 1993. Preliminary Report--The Little Skull Mountain Earthquake, June 29, 1992. In: Dynamic Analysis and Design Considerations for HighLevel Nuclear Waste Repositories. Structural Division/American Society of Civil Engineers, pp. 162-175.

Barnes, H., F. N. Houser, and F. G. Poole, 1963. “Geologic Map of the Oak Spring Quadrangle, Nye County, Nevada.” U.S. Geological Survey Map GQ-214, scale 1:24,000. Washington, DC.

Barnes, H., E. B. Ekren, C. L. Rodgers, and D. C. Hedlund, 1982. "Geology and Tectonic Maps of the Mercury Quadrangle, Nye and Clark Counties, Nevada.” U.S. Geological Survey, Miscellaneous Geologic Investigations Series Map I-1197, scale 1:24,000.

Bechtel Nevada, 2002. A Hydrostratigraphic Model and Alternatives for the Groundwater Flow and Contaminant Transport Model of Corrective Action Units 101 and 102: Central and Western Pahute Mesa, Nye County, Nevada. DOE/NV/11718--706. Las Vegas, NV.

Bechtel Nevada, 2005. Site Characterization and Monitoring Data from Area 5 Pilot Wells, Nevada Test Site, Nye County, Nevada. DOE/NV/11718--1067. Las Vegas, NV.

Blankennagel, R. K., and J. E. Weir, Jr., 1973. Geohydrology of the Eastern Part of Pahute Mesa, Nevada Test Site, Nye County, Nevada. U.S. Geological Survey Professional Paper 712-B, 35 pp., Washington, DC.

Blout, D. O., W. S. Birchfiel, D. P. Hammermeister, K. A. Zukosky, and K. D. Donnelson, 1995. Site Characterization Data from Area 5 Science Boreholes, NTS, Nye County, Nevada. DOE/NV/11432-170. Reynolds Electrical \& Engineering Co., Inc. Las Vegas, NV.

BN, see Bechtel Nevada.

Burchfiel, B. V., 1964. "Precambrian and Paleozoic Stratigraphy of the Specter Range Quadrangle, Nye County, Nevada.” American Association of Petroleum Geologists Bulletin, v. 48, pp. 40-56.

Byers, F. M., Jr., and C. H. Miller, 1966. Geologic and Geophysical Log of the Ue5k Exploratory Hole, Frenchman Flat, Nevada Test Site. U.S. Geological Survey Technical Letter NTS-164.

Byers, F. M., W. J. Carr, P. P. Orkild, 1989. "Volcanic Centers of Southwestern Nevada: Evolution of Understanding, 1960-1988.," Journal of Geophysical Research, v. 94, no. 5, p. 5908-5924. 
Carle S. F., M. Zavarin, and G. A. Pawloski, 2002. Geostatistical Analysis of Spatial Variability of Mineral Abundance and Kd in Frenchman Flat, NTS, Alluvium. UCRL-ID-150200, Lawrence Livermore National Laboratory, Livermore, California.

Carr, W. J., G. D. Bath, D. L. Healey, and R. M. Hazlewood, 1975. Geology of Northern Frenchman Flat, Nevada Test Site. U.S. Geological Survey Report, USGS-474-216.

Carroll, R. D., 1963. Interpretation of Geophysical Logs, Test Well F, Nevada Test Site. U.S. Geological Survey Technical Letter NTS-54.

Cashman, P. H., and J. H. Trexler, Jr. 1991. "The Mississippian Antler Foreland and Continental Margin in Southern Nevada: The Eleana Formation Reinterpreted.” In: Paleozoic Paleogeography of the Western United States - II: Pacific Section SEPM; v. 67: 271-280.

Cashman, P. H., and J. H. Trexler, Jr., 1994. The Case for Two Coeval Mississippian Sections at the Nevada Test Site. 27th Annual Cordilleran Section Meeting, San Bernardino, CA. p. 76-81. Geological Society of America.

Case, C. M., J. Davis, R. French, and S. Racker, 1984. Site Characterization in Connection with the Low-Level Defense Waste Management Site in Area 5 of the Nevada Test Site, Nye County, Nevada - Final Report. DOE/NV/10162-13. Las Vegas, NV: Desert Research Institute.

Caskey, S. J., 1991. Mesozoic and Cenozoic Structural Geology of the CP Hills, Nevada Test Site, Nye County, Nevada; and Regional Implications. State of Nevada Agency for Nuclear Project/Nuclear Waste Project Office. Report Number NWPO-TR-018-91.

Claassen, H. C., 1973. Water Quality and Physical Characteristics of Nevada Test Site WaterSupply Wells. U.S. Geological Survey Report. USGS-474-158 (NTS-242).

Cole, J. C., U.S. Geological Survey, 1992. Written communication to S. L. Drellack regarding thickness of Paleozoic units at the NTS.

Cole, J. C., and P. H. Cashman, 1999. Structural Relationships of Pre-Tertiary Rocks in the Nevada Test Site Region, Southern Nevada. U.S. Geological Survey Professional Paper 1607.

D’Agnese, F. A., C. C. Faunt, A. K. Turner, and M. C. Hill, 1997. Hydrogeologic Evaluation and Numerical Simulations of the Death Valley Regional Groundwater Flow System, Nevada and California. U.S. Geological Survey Professional Paper 1607, Denver CO.

Dixon, G. L., W. J. Carr, and W. P. Williams, 1967. Geologic and Geophysical Log of Drill Hole Ue5i, Nevada Test Site. U.S. Geological Survey Technical Letter NTS-186.

DOE, see U.S. Department of Energy. 
Drellack, S. L., Jr., 1997. Selected Stratigraphic Data for Drill Holes Located in Frenchman Flat, Nevada Test Site, Revision 1. DOE/NV/11718--077. Bechtel Nevada, Las Vegas, NV

Faunt, C. C., 1998. Effects of Faulting on Groundwater Movement in the Death Valley Region, Nevada and California. U. S. Geological Survey Water Resources Investigations Report 95-4132, Denver, CO.

Faunt, C. C., W. R. Belcher, F. A. D’Agnese, 1999. “Using Geologic Data for a ThreeDimensional Hydrogeologic Framework Model of the Death Valley Region.” In: J. L. Slate, ed., Proceedings of Conference on Status of Geological Research and Mapping in Death Valley National Park. U.S. Geological Survey Open File Report 99-153. Denver, CO.

FFACO, see Federal Facility Agreement and Consent Order.

Federal Facility Agreement and Consent Order, 1996, as amended. Agreed to by the U.S. Department of Energy, the U.S. Department of Defense, and the State of Nevada. Las Vegas, NV.

Ferguson, J. R., A. H. Cogbill, and R. G. Warren, 1994. “A Geophysical-Geological Transect of the Silent Canyon Caldera Complex, Pahute Mesa, Nevada.” Journal of Geophysical Research, v. 99, n. 33: 4323-4339.

Fischer, F.G., P. J. Papanek, and R. M. Hamilton, 1972. “The Massachusetts Mountain Earthquake of 5 August 1971, and its Aftershocks, Nevada Test Site.” U.S. Geological Survey Report USGS-474-149 [NTS-238], 16 pp.

Gibbons, A. B., E. N. Hinrichs, W. R. Hansen, and R. W. Lemke, 1963. Geology of the Rainier Mesa Quadrangle, Nye County, Nevada. U.S. Geological Survey Geologic Quadrangle Map GQ-215, scale 1:24,000 (TEI-754).

Gonzales, J. L., S. L. Drellack, and M. T. Townsend, 1998. Written communication. Subject: Descriptive narrative for the Hydrogeologic Model at the Yucca Flat Corrective Area Unit. An interim report. Bechtel Nevada, Las Vegas, NV.

Grauch, V. J. S., and M. R. Hudson, 1995. Preliminary Analysis of Major Structures and Lithologic Boundaries for the Frenchman Flat Model Area. Denver, CO: U.S. Geological Survey.

Grasso, D. N., 2003. Geologic Surface Effects of Underground Nuclear Testing, Buckboard Mesa, Climax Stock, Dome Mountain, Frenchman Flat, Rainier/Aqueduct Mesa, and Shoshone Mountain, Nevada Test Site, Nevada. USGS Open File Report 03-125.

Hansen, D. J., P. D. Greger, C. A. Wills, and W. K. Ostler, 1997. Nevada Test Site Wetlands Assessment. Bechtel Nevada Report. DOE/NV/11718--124. Las Vegas, NV.

Healey, D. L., 1965. An Evaluation of Northeastern Frenchman Flat Based on Gravity Data. U.S. Geological Survey Technical Letter NTS-158. 
Healey, D. L., M. A. Pistrang, and H. Barnes, 1967. Proposed Ue5m Test Area, Southwest Frenchman Flat, Nevada Test Site. U.S. Geological Survey Technical Letter NTS-189.

Healey, D. L., R. N. Harris, D. A. Ponce, and H. W. Oliver, 1987. Complete Bouguer Gravity Map of the Nevada Test Site and Vicinity, Nevada. U.S. Geological Survey Open-File Report 87-506, scale: 1:100,000.

Hinrichs, E. N., 1968. “Geologic Map of the Camp Desert Rock Quadrangle Nye County, Nevada.” U.S. Geological Survey Quadrangle Map G-726, scale 1:24,000.

Hinrichs, E. N., and E. J. McKay, 1965. "Geologic Map of the Plutonium Valley Quadrangle, Nye and Lincoln Counties, Nevada.” U.S. Geological Survey Geologic Quadrangle Map 384 , scale 1:24,000.

Hudson, M. R., 1992. "Paleomagnetic Data Bearing on the Origin of Arcuate Structures in the French Peak-Massachusetts Mountain Area of Southern Nevada.” Geological Society of America Bulletin, v. 104: 581-594.

Hudson, M. R., 1997. Structural Geology of the French Peak Accommodation Zone, Nevada Test Site, Southwestern Nevada. U. S. Geological Survey Open File Report 97-56.

IT, see IT Corporation.

IT Corporation, 1996a. Groundwater Flow Model Documentation Package (Phase I Data Analysis Documentation, Volume VI). ITLV/10972-181. Prepared for the U.S. Department of Energy, Nevada Operations Office. Las Vegas, NV.

IT Corporation, 1996b. Hydrologic Parameter Data Documentation Package (Phase I Data Analysis Documentation, Volume IV), ITLV/10972-181. Prepared for the U.S. Department of Energy, Nevada Operations Office. Las Vegas, NV.

IT Corporation, 1996c. Regional Geologic Model Documentation Package (Phase I Data Analysis Documentation, Volume I, Parts 1 and 2). ITLV/10972-181. Prepared for the U.S. Department of Energy, Nevada Operations Office. Las Vegas, NV.

IT Corporation, 1996d. Groundwater Recharge and Discharge Data Documentation Package (Phase I Data Analysis Documentation, Volume III). ITLV/10972-181. Prepared for the U.S. Department of Energy, Nevada Operations Office. Las Vegas, NV.

IT Corporation, 1997. Value of Information Analysis Corrective Action Unit No. 98 for Frenchman Flat. IT Report ITLV/10972-192.

IT Corporation, 1998. Underground Test Area Subproject, Corrective Action Unit 98: Frenchman Flat Data Analysis Task, Volume I- Hydrostratigraphic Model Documentation Package, Draft. ITLV/13052-044. 
IT Corporation, 1999a. Digital Elevation Model Database for the NTS and Vicinity.

Las Vegas, NV.

IT Corporation, 1999b. External Peer Review Group Report on Frenchman Flat Data Analysis and Modeling Task, Underground Test Area Project. ITLV/13052--077. Las Vegas, NV

IT Corporation, 1999c. Written communication. Subject: Underground Test Area Project Corrective Action Unit 98: Frenchman Flat, Vol. III - Groundwater Flow and Contaminant Transport Model Data Documentation Package. Prepared for U.S. Department of Energy, Nevada Operations Office. Las Vegas, NV.

IT Corporation, 2000. Frenchman Flat Hydrogeologic Investigation Wells Drilling and Completion Criteria. ITLV/13052-094. Las Vegas, Nevada.

IT Corporation, 2001. Addendum to Frenchman Flat Hydrogeologic Investigation Wells Drilling and Completion Criteria. ITLV/13052-094-Rev.1-ADD. Las Vegas, Nevada.

IT Corporation, 2002. Written communication. Subject: Integrated Data Report for the Multiple-Well Aquifer Test at Frenchman Flat Well Cluster ER-5-3. Las Vegas, NV.

Jachens, R. C. and B. C. Moring, 1990. Maps of the Thickness of Cenozoic Deposits and the Isostatic Residual Gravity Over Basement for Nevada. U.S. Geological Survey Open File Report 90-0404, 15 p, scale: 1:1,000,000.

Kirchoff-Stein, K. S., D. A. Ponce, and B. A. Chuchel, 1989. Preliminary Aeromagnetic Map of the Nevada Test Site and Vicinity, Nevada. U.S. Geological Survey Open File Report 89-446, scale: 1:100,000.

Laczniak, R. J., J. C. Cole, D. A. Sawyer, and D. A. Trudeau, 1996. Summary of Hydrogeologic Controls on the Movement of Groundwater at the Nevada Test Site, Nye County, Nevada. U.S. Geological Survey, Water-Resources Investigations Report 96-4109. Carson City, NV.

Marsh, K. V., 1992. Hydrology and Radionuclide Migration Program 1988 Progress Report. Lawrence Livermore National Laboratory Report, UCRL-53779-88. Livermore, CA.

McCafferty, A. E., and F. J. Grauch, 1997. Aeromagnetic and Gravity Anomaly Maps of the Southwestern Nevada Volcanic Field, Nevada and California. U.S. Geological Survey Geophysical Investigation Map GP-1015, scale 1:250,000.

McKeown, F. A., D. L. Healey, and C. H. Miller, 1976. “Geologic Map of the Yucca Lake Quadrangle, Nye County, Nevada.” U.S. Geological Survey GQ-1327, scale 1:24,000.

Miller, C. H., and D. L. Healey, 1986. Gravity Interpretation of Frenchman Flat and Vicinity, NTS. U.S. Geological Survey Open File Report 86-211. 
Miller, J. J., D. L. Gustafson, and K. E. Snyder, 1993. “Lineaments Identified in Northern Frenchman Flat, Nye, Lincoln, and Clark Counties, Nevada.” Map Scale 1:24,000. Las Vegas, NV: Raytheon Services Nevada.

Naeser, C. W., and F. Maldonado, 1981. Fission-Track Dating of the Climax and Gold Meadows Stocks, Nye County, Nevada. In: Short Contributions to Geochronology: U.S. Geological Survey Professional Paper 1199E, pp. 45-47.

National Geophysical Company, Inc, 1966. Seismic Survey Report on the Frenchman Flat Area, Nevada Test Site Areas 5 and 11, Nye County, Nevada. Dallas, TX: National Geophysical Company, Inc.

Nevada Bureau of Mines and Geology, 1996. County Digital Geologic Mapping Project- Final Report. Open-File Report 97-1. Scale 1:250,000.

Pawloski, G.A., 1996. Written communication. Subject: Review of Data in Frenchman Flat, with Special Emphasis on Alluvium and Porosity. Lawrence Livermore National Laboratory informal report. Livermore, CA.

Phelps, G. A., and S. E. Graham, 2002. Preliminary Gravity Inversion Model of Frenchman Flat Basin, Nevada Test Site, Nevada. U.S. Geological Survey Open-File Report 02-363.

Phelps, G. A., L. Justet, B. C. Moring, and C. W. Roberts, 2005. A Preliminary Investigation of the Structure of Southern Yucca Flat, Massachusetts Mountain, and CP Basin, Nevada Test Site, Nevada, Based on Geophysical Modeling. U.S. Geological Survey Open-File Report (in press).

Ponce, D. A., R. N. Harris, and H. W. Oliver, 1988. Isostatic Gravity Map of the Nevada Test Site and Vicinity, Nevada. U.S. Geological Survey Open File Report 88-664, scale: $1: 100,000$.

Ponce, D. A., E. A. Mankinen, J. G. Davidson, R. L. Morin, and R. J. Blakely, 1999. Digital Isostatic Gravity Map of the Nevada Test Site Area, Nye, Lincoln, and Clark Counties, Nevada and Inyo County, California. U.S. Geological Survey Open File Report 99-554c, CD-ROM, scale 1:100,000.

Ponce, D. A., 1999. Digital Aeromagnetic Map of the Nevada Test Site Area, Nye, Lincoln, and Clark Counties, Nevada and Inyo County, California. U.S. Geological Survey Open File Report 99-55413, CD-ROM, scale 1:100,000.

Poole, F. G., 1965. “Geologic Map of the Frenchman Flat Quadrangle, Nye, Lincoln, and Clark Counties, Nevada.” U.S. Geological Survey Geologic Quadrangle Map GC-456, scale $1: 24,000$.

Poole, F. G., F. N. Houser, and P. P. Orkild, 1961. Eleana Formation of Nevada Test Site and Vicinity, Nye County, Nevada. U. S. Geological Survey Professional Paper 424-D, pp. D104-D111. 
Poole, F. G., R. E. Davis, and J. R. Ege, and D. L. Hoover, 1963. Geology of a Strip Between Cane Spring Road and Mara Wash, Nevada Test Site. U.S. Geological Survey Technical Letter NTS-52.

Poole, F. G., D. P. Elston, and W. J. Carr, 1965. "Geologic Map of the Cane Spring Quadrangle, Nye County, Nevada,” U.S. Geological Survey Geologic Quadrangle Map GQ-455, scale $1: 24,000$.

Prothro, L. B., and S. L. Drellack, Jr., 1997. Review and Reconnaissance of the Hydrogeology of Tertiary Sedimentary Rocks in the Vicinity of Frenchman Flat, Nevada Test Site, DOE/NV/11718-155. Bechtel Nevada. Las Vegas, NV.

Prothro, L. B., 2002. Written communication. Subject: Geologic Interpretation of the Frenchman Flat 3-D Seismic Data. Bechtel Nevada. Las Vegas, NV.

Pullammanappallil, S. K., and J. N. Louie, 1994. Written communication. Subject: Seismic Refraction Analysis of the Cane Spring Fault, Southern Nevada. Project Report to Raytheon Services Nevada. Reno, NV: University of Nevada-Reno, Mackay School of Mines.

Raytheon Services Nevada, 1990. Nevada Test Site Drilling and Mining Summary. Las Vegas, NV.

Raytheon Services Nevada, 1994. Written communication. Subject: Summary of Volcanic Activity at the Area 5 Radioactive Waste Management Site, DOE/Nevada Test Site, Nye County, Nevada. Las Vegas, NV.

REECo, see Reynolds Electrical \& Engineering Co., Inc.

Reynolds Electrical \& Engineering Co., Inc., 1993a. Hydrogeologic Data for Existing Excavations at the Area 5 Radioactive Waste Management Site, Nevada Test Site, Nye County, Nevada. DOE/NV/11432-40, UC 721. Las Vegas, NV.

Reynolds Electrical \& Engineering Co., Inc. 1993b. Hydrogeologic Data for Science Trench Boreholes at the Area 5 Radioactive Waste Management Site, Nevada Test Site, Nye County, Nevada. DE-AC08-94-NV11432, UC 721. Las Vegas, NV.

RSN, see Raytheon Services Nevada.

Sawyer, D. A., R. J. Fleck, M. A. Lamphere, R. G. Warren, and D. E. Broxton, 1994. "Episodic Caldera Volcanism in the Miocene Southwest Nevada Volcanic Field: Revised Stratigraphic Caldera Framework, 40Ar/39Ar Geochronology and Implications for Magmatism and Extension.” Geological Society of America Bulletin, v. 67, n. 10: 1304-1318.

Scott, J. H., 1962. Shallow Electrical Resistivity Measurements of Alluvium in Frenchman Flat, NTS, U.S. Geological Survey Technical Letter, Small Boy-002. 
Scott, J. H., and R. A. Black, 1962. Deep Electrical Resistivity Measurements at Frenchman Flat, NTS, U.S. Geological Survey Technical Letter, Small Boy-004.

Shott, G. J., C. J. Muller, L. E. Barker, D. E. Cawlfield, F. T. Lindstrom, D. G. Linkenheil, M. J. Sully, L. McDowell-Boyer, and D.J. Thune, 1995. Performance Assessment for the Area 5 Radioactive Waste Management Site at the Nevada Test Site, Nye County, Nevada. DOE/NV/11432-196.

Shott, G. J., L. E. Barker, S. E. Rawlinson, M. J. Sully, and B. A. Moore, 1998. Written communication. Subject: Performance Assessment of the Area 5 RWMS at the NTS, Nye County, Nevada, Revision 2.1. DOE/NV/11718--176. Prepared by Bechtel Nevada for U.S. Department of Energy, Nevada Operations Office. Las Vegas, NV.

Slate, J. L., M. E. Berry, P. D. Rowley, C. J. Fridrich, K. S. Morgan, J. B. Workman, O. D. Young, G. L. Dixon, V. S. Williams, E. H. McKee, D. A. Ponce, T. G. Hilderbrand, WC Swadley, S. C. Lundstrom, E. B. Ekren, R. G. Warren, J. C. Cole, R. J. Fleck, M. A. Lanphere, D. A. Sawyer, S. A. Minor, D. J. Grunwald, R. J. Laczniak, C. M. Menges, J. C. Yount and A. S. Jayko, 1999. Digital Geologic Map of the Map of the Nevada Test Site and Vicinity, Nye, Lincoln, and Clark Counties, Nevada and Inyo County, California. U.S. Geological Survey Open-File Report 99B554BA, scale 1:120,000.

SNJV, see Stoller-Navarro Joint Venture.

Snyder, K. E., D. L. Gustafson, J. J. Miller, and S. E. Rawlinson, 1994. Geologic Components of Site Characterization and Performance Assessment for a Radioactive Waste Management Facility at the Nevada Test Site. DOE/NV/10833-20. Las Vegas, NV: Raytheon Services Nevada.

Snyder, K. E., D. L. Gustafson, H. E. Huckins-Gang, J. J. Miller, and S. E. Rawlinson, 1995. Surficial Geology and Performance Assessment for a Radioactive Waste Management Facility at the Nevada Test Site. DOE/NV/10833-25. Las Vegas, NV: Raytheon Services Nevada

Stewart, J. H., and J. E. Carlson, 1978. Geologic Map of Nevada. Scale 1:500,000. U.S. Geological Survey, Reston, VA.

Stewart, J. H., 1998. "Regional Characteristics, Tilt Domains, and Extensional History of the Late Cenozoic Basin and Range Province, Western North America.” In: Faulds, J. E., and J. H. Stewart, eds., Accommodation Zones and Transfer Zones: The Regional Segmentation of the Basin and Range Province. Geological Society of America Special Paper 323. Boulder, CO.

Stoller-Navarro Joint Venture, 2004a. Written communication. Subject: Interpretation of Hydraulic Test and Multiple-Well Aquifer Test Data at Frenchman Flat Well Cluster ER-5-3. Las Vegas, NV. 
Stoller-Navarro Joint Venture, 2004b. Phase II Hydrologic Data for the Groundwater Flow and Contamination Transport Model of CAU Unit 98: Frenchman Flat, Nye County, Nevada. S-N/99205-032, Revision 0. Las Vegas, NV.

Stoller-Navarro Joint Venture, 2005a. Phase II Contaminant Transport Parameters for the Groundwater Flow and Contaminant Transport Model of Corrective Action Unit 98: Frenchman Flat, Nye County, Nevada. Prepared for the U.S. Department of Energy. Report Number S-N/99205--043. Las Vegas, NV.

Stoller-Navarro Joint Venture, 2005b. Written communication. Subject: Unclassified Source Term and Radionuclide Data for Corrective Action Unit 98: Frenchman Flat, Nevada. Las Vegas, NV

Sully, M. J., D. E. Cawlfield, D. O. Blout, L. E. Barber, B. L. Dozier, and D. P. Hammermeister, 1993. Written communication. Subject: Characterization of the Spatial Variability of Hydraulic Properties at the Area 5 Radioactive Waste Management Site. Las Vegas, NV: Reynolds Electrical \& Engineering Co., Inc.

Sweetkind, D., R. P. Dickerson, R. J. Blakely, and P. D. Denning, 2001. Interpretive Geologic Cross Sections for the Death Valley Regional Flow System and Surrounding Areas, Nevada and California. U.S. Geologic Survey Misc. Field Studies Map MF-2370.

Trexler, J. H., Jr., J. C. Cole, and P. H. Cashman, 1996. Middle Devonian-Mississippian Stratigraphy on and near the Nevada Test Site: Implications for Hydrocarbon Potential. American Association of Petroleum Geologists Bulletin, v. 80, n. 11, pp. 1736-1762. Tulsa, OK.

Tschanz, C. M., and E. H. Pampeyan, 1970. "Geology and Mineral Deposits of Lincoln County, Nevada, Recently Dated as Miocene.” In: Nevada Bureau of Mines and Geology Bulletin 73.

Twiss, R. J. and E. M. Moores, 1992. Structural Geology. W. H. Freeman and Company, New York, 530 pp.

U.S. Department of Energy, Nevada Operations Office, 1998. Routine Radiological Environmental Monitoring Plan, Report DOE/NV/11718--244. Prepared by Bechtel Nevada. Las Vegas, NV.

U.S. Department of Energy, Nevada Operations Office, 1999. Corrective Action Investigation Plan for Corrective Action Unit 98: Frenchman Flat, Nevada Test Site, Nevada, DOE/NV-478-Rev. 1. Prepared by IT Corporation. Las Vegas, NV.

U.S. Department of Energy, Nevada Operations Office, 2000a. Addendum to Revision 1 of the Corrective Action Investigation Plan for Corrective Action Unit 98: Frenchman Flat, Nevada Test Site, Nevada. DOE/NV-478-Rev. 1-Add. Prepared by IT Corporation. Las Vegas, NV. 
U.S. Department of Energy, Nevada Operations Office, 2000b. United States Nuclear Tests, July 1945 through September 1992. DOE/NV-209, Revision 15. Las Vegas, NV.

U.S. Department of Energy, National Nuclear Security Administration Nevada Site Office, 2004. Nevada Test Site Environmental Report 2003. DOE/NV/11718--971. Prepared by Bechtel Nevada. Las Vegas, NV.

U.S. Department of Energy, National Nuclear Security Administration Nevada Site Office, 2005a. Well Completion Report for Well Cluster ER-5-3. Report DOE/NV/11718--1093. Prepared by Bechtel Nevada. Las Vegas, NV.

U.S. Department of Energy, National Nuclear Security Administration Nevada Site Office, 2005b. Well Completion Report for Well Cluster ER-5-4. Report DOE/NV/11718--998. Prepared by Bechtel Nevada. Las Vegas, NV

USGS, see U.S. Geological Survey.

Waddell, R. K., Jr., J. H. Robison, and R. K. Blankennagel, 1984. Hydrology of Yucca Mountain and Vicinity, Nevada-California: Investigative Results Through Mid-1983, USGS-WRIR-84-4267, Water Resources Investigation Report. Denver, CO: U.S. Geological Survey.

Wagoner, J. L., and W. Richardson, 1986. Stratigraphic Contacts from Drill Holes at the Nevada Test Site, Lawrence Livermore National Laboratory Report, UCID-20790. Livermore, CA.

Wahl, R. R., U.S. Geological Survey, 1995. Written communication to Ed Price, HSI-GeoTrans, “Analysis of Gravity Data Along Profile KR1, Frenchman Flat, Nevada.” November 2,1995. Golden, CO.

Wahl, R. R., D. A. Sawyer, S. A. Minor, M. D. Carr, J. C. Cole, WC Swadley, R. J. Laczniak, R. G. Warren, K. S. Green, and C. M. Engle, 1997. "Digital Geologic Map Database of the Nevada Test Site area, Nevada.” U.S. Geological Survey Open-File Report 97-140, CD-ROM, scale 1:100,000.

Warren, R.G., Los Alamos National Laboratory, 1995. Personal communication to S. L. Drellack, Bechtel Nevada, regarding the hydrology of the Wahmonie Formation in Frenchman Flat. Los Alamos, NM.

Warren, R. G., F. C. Benedict Jr., T. P. Rose, D. K. Smith, S. J. Chipera, E. C. Kluk, and K. M. Raven, 2002. Alluvial Layering and Distribution of Reactive Phases within Drill Holes ER-5-4 and UE-5n of Frenchman Flat. Los Alamos National Laboratory Report LA-UR-02-6206.

West, L. R., and M. S. Garber, 1961. Abridged Log of Ground-Water Test Well F, 410 Area, Nevada Test Site, Nevada. U.S. Geological Survey Technical Letter NTS-12. 
Winograd, I. J., and W. Thordarson, 1975. Hydrogeologic and Hydrochemical Framework, South-Central Great Basin, Nevada-California, with Special Reference to the Nevada Test Site. U.S. Geological Survey Professional Paper 712-C.

Workman, J. B., C. Menges, W. R. Page, E. Taylor, E. B. Ekren, P. D. Rowley, G. L. Dixon, R. A. Thompson, and L. A. Wright, 2002. Geologic Map of the Death Valley Groundwater Basin and Surrounding Areas, Nevada and California. U.S. Geologic Survey Misc. Field Studies Map No. MF 2381-A, Scale 1:250,000.

Yount, J. C. U.S. Geological Survey, 1996. Verbal communication to L. B. Prothro regarding the rocks of Winapi Wash.

Zavarin M., S. K. Roberts, T. P. Rose, and D. L. Phinney, 2002. Validating Mechanistic Sorption Model Parameters and Processes for Reactive Transport in Alluvium. Lawrence Livermore National Laboratory Report UCRL-ID-149728, Livermore, CA.

Zavarin M., S. F. Carle, and R. M. Maxwell, 2004. Upscaling Radionuclide Retardation Linking the Surface Complexation and Ion Exchange Mechanistic Approach to a Linear Kd Approach. Report on work performed for the UGTA program, Lawrence Livermore National Laboratory Report UCRL-TR-214713, Livermore, CA.

Zonge Engineering and Research Organization, Inc., 1990. Written communication prepared for Holmes and Narver, Inc. Subject: Final Report: Vector CSAMT Survey, Frenchman Flat Project, Nevada Test Site. Tucson, AZ. 
This page intentionally left blank. 


\section{Distribution List}

\section{$\underline{\text { Copies }}$}

W. R. Wilborn

U.S. Department of Energy

11 (7 electronic)

National Nuclear Security Administration

Nevada Site Office

Environmental Restoration Division

P.O. Box 98518, M/S 505

Las Vegas, NV 89193-8518

U.S. Department of Energy

1 (uncontrolled)

National Nuclear Security Administration

Nevada Site Office

Technical Library

P.O. Box 98518, M/S 505

Las Vegas, NV 89193-8518

U.S. Department of Energy

National Nuclear Security Administration

2 (electronic, uncontrolled)

Nevada Site Office

Public Reading Facility

c/o Nuclear Testing Archive

P.O. Box 98518, M/S 505

Las Vegas, NV 89193-8518

U.S. Department of Energy

Office of Scientific and Technical Information

P.O. Box 62

Oak Ridge, Tennessee 37831-0062

Northern Nevada FFACO Public Reading Room

c/o Nevada State Library and Archive

100 West Stuart Street

Carson City, NV 89701-4208

A. Aly

Stoller-Navarro Joint Venture

7710 W. Cheyenne, Bldg. 3, M/S 439

Las Vegas, NV 89129

T. C. Beard

Stoller-Navarro Joint Venture

7710 W. Cheyenne, Bldg. 3, M/S 439

Las Vegas, NV 89129
1 (electronic, uncontrolled)

1 (electronic, uncontrolled)

2 (1 electronic)

1 (electronic) 


\title{
Distribution List, continued
}

$\underline{\text { Copies }}$

N. M. Becker

Los Alamos National Laboratory

2 (1 electronic)

P. O. Box 1663, EES-6, M/S F-665

Los Alamos, NM 87545-1663

N. M. DeNovio

2 (1 electronic)

Stoller-Navarro Joint Venture

7710 W. Cheyenne, Bldg. 3, M/S 439

Las Vegas, NV 89129

S. L. Drellack

2 (1 electronic)

Bechtel Nevada

P.O. Box 98521, NSF082

Las Vegas, NV 89193-8521

J. L. Gonzales

1 (electronic)

Bechtel Nevada

P.O. Box 98521, NSF082

Las Vegas, NV 89193-8521

J. P. McCord

2 (1 electronic)

Stoller-Navarro Joint Venture

7710 W. Cheyenne, Bldg. 3, M/S 439

Las Vegas, NV 89129

P. K. Ortego

1 (electronic)

Bechtel Nevada

P.O. Box 98521, NSF082

Las Vegas, NV 89193-8521

G. A. Pawloski

2 (1 electronic)

Lawrence Livermore National Laboratory

P. O. Box 808

Livermore, CA 94551-0808

G. A. Phelps

U.S. Geological Survey

345 Middlefield Road

Menlo Park, CA 94025

L. B. Prothro

1 (electronic)

Bechtel Nevada

P.O. Box 98521, NSF082

Las Vegas, NV 89193-8521

1 (electronic)

\author{
(electronic)
}




\section{Distribution List, continued}

\section{$\underline{\text { Copies }}$}

S. E. Rawlinson

1 (electronic)

Bechtel Nevada

P.O. Box 98521, NTS416

Las Vegas, NV 89193-8521

C. E. Russell

2 (1 electronic)

Desert Research Institute

755 East Flamingo Road

P.O. Box 19040

Las Vegas, NV 89119-7363

Stoller Navarro Central Files

2 (1 electronic)

Stoller-Navarro Joint Venture

7710 W. Cheyenne, Bldg. 3, M/S 439

Las Vegas, NV 89129

B. K. Thompson

Water Resources, Nevada District

2 (1 electronic)

U.S. Geological Survey

160 N. Stephanie Street

Henderson, NV 89074

M. J. Townsend

2 (1 electronic)

Bechtel Nevada

P.O. Box 98521, NTS416

Las Vegas, NV 89193-8521 


\section{APPENDIX A}

Geologic and Hydrostratigraphic Drill Hole Database for the Frenchman Flat Model Area 
Appendix A.

Hydrostratigraphic Database for Drill Holes in the Frenchman Flat Area.

Page 1 of 8

\begin{tabular}{|c|c|c|c|c|c|c|c|c|c|c|c|}
\hline Hole Name & Strat $^{1}$ & Lith $^{1}$ & Major Alter. ${ }^{1}$ & $\mathrm{HGU}^{2}$ & $\mathrm{HSU}^{3}$ & $\begin{array}{l}\text { Depth } \\
\text { Top }^{4}(\mathrm{ft})\end{array}$ & $\begin{array}{c}\text { Depth } \\
\text { Top }^{4}(\mathrm{~m})\end{array}$ & $\begin{array}{c}\text { Elev. Top } \\
\text { (ft) }\end{array}$ & $\begin{array}{c}\text { Elev. Top } \\
\text { (m) }\end{array}$ & $\mathrm{TD}^{6}(\mathrm{ft})$ & $\mathrm{TD}^{6}(\mathrm{~m})$ \\
\hline ER-5-3 & QTa & $A L$ & $\mathrm{CC}$ & AA & $\mathrm{AA}^{10}$ & 0.0 & 0.0 & $3,334.3$ & $1,016.3$ & $2,610.0$ & 795.5 \\
\hline ER-5-3 & QTa & $\mathrm{AL}$ & CC/ZE & AAA & OAA & 590.0 & 179.8 & $2,744.3$ & 836.5 & & \\
\hline ER-5-3 & Tybf & BS & DV & LFA & BLFA & 903.0 & 275.2 & $2,431.3$ & 741.1 & & \\
\hline ER-5-3 & QTa & $A L$ & CC/ZE & AAA & $\mathrm{OAA}^{12}$ & 933.0 & 284.4 & $2,401.3$ & 731.9 & & \\
\hline ER-5-3 & Ttp & BED & GL/ZE & VTA & OAA1 & $1,665.0$ & 507.5 & $1,669.3$ & 508.5 & & \\
\hline ER-5-3 & QTa & $\mathrm{AL}$ & CC/ZE & AAA & OAA1 & $1,682.0$ & 512.7 & $1,651.4$ & 503.3 & & \\
\hline ER-5-3 & Tmar & MWT & DV & WTA & TM-WTA & $2,042.0$ & 622.4 & $1,292.3$ & 393.9 & & \\
\hline ER-5-3 & Tmar & DWT & DV & WTA & TM-WTA & $2,130.0$ & 649.2 & $1,204.3$ & 367.1 & & \\
\hline ER-5-3 & Tmar & MWT & DV & WTA & TM-WTA & $2,176.0$ & 663.2 & $1,158.3$ & 353.1 & & \\
\hline ER-5-3 & Tmap & PWT & GL/ZE & VTA & TM-WTA & $2,262.0$ & 689.5 & $1,072.3$ & 326.8 & & \\
\hline ER-5-3 & Tmab & BED & GL/ZE & VTA & TM-WTA & $2,306.0$ & 702.9 & $1,028.3$ & 313.4 & & \\
\hline ER-5-3 & Tmrr & NWT/PWT & ZE & TCU & TM-WTA & $2,334.0$ & 711.4 & $1,000.3$ & 304.9 & & \\
\hline ER-5-3 & Tmrr,Tmrp & PWT/MWT & DV/VP & WTA & TM-WTA & $2,370.0$ & 722.4 & 964.3 & 293.9 & & \\
\hline ER-5-3 & Tmrp & MWT/DWT & DV & WTA & TM-WTA & $2,510.0$ & 765.1 & 824.3 & 251.3 & & \\
\hline ER-5-3 & Tmrp & DWT & DV & WTA & TM-WTA & $2,530.0$ & 771.1 & 804.3 & 245.2 & & \\
\hline ER-5-3 & Tmrp & MWT & DV/VP & WTA & TM-WTA & $2,590.0$ & 789.4 & 744.3 & 226.9 & & \\
\hline ER-5-3\#2 & QTa & $\mathrm{AL}$ & $\mathrm{CC}$ & AA & AA3 & 0.0 & 0.0 & $3,334.3$ & $1,017.2$ & $5,683.0$ & 1732.2 \\
\hline ER-5-3\#2 & QTa & $\mathrm{AL}$ & $\mathrm{CC} / \mathrm{ZE}$ & AAA & OAA & 590.0 & 178.8 & $2,744.3$ & 836.5 & & \\
\hline ER-5-3\#2 & Tybf & $\mathrm{BS}$ & DV & LFA & BLFA & 910.0 & 277.4 & $2,424.3$ & 738.9 & & \\
\hline ER-5-3\#2 & QTa & $\mathrm{AL}$ & CC/ZE & AAA & OAA1 & 940.0 & 286.5 & $2,394.3$ & 729.8 & & \\
\hline ER-5-3\#2 & Ttp & BED & GL/CC & VTA & OAA1 & $1,680.0$ & 512.1 & $1,654.3$ & 504.2 & & \\
\hline ER-5-3\#2 & QTa & $\mathrm{AL}$ & CC/ZE & AAA & OAA1 & $1,695.0$ & 516.6 & 1,639.3 & 499.7 & & \\
\hline ER-5-3\#2 & Tmar & MWT & DV & WTA & TM-WTA & $2,060.0$ & 627.9 & $1,274.3$ & 388.4 & & \\
\hline ER-5-3\#2 & Tmar & DWT & DV/VP & WTA & TM-WTA & $2,140.0$ & 652.3 & $1,194.3$ & 364.0 & & \\
\hline ER-5-3\#2 & Tmar & MWT & DV & WTA & TM-WTA & $2,190.0$ & 667.5 & $1,144.3$ & 348.8 & & \\
\hline ER-5-3\#2 & Tmap & PWT & GL/ZE/VP & VTA & TM-WTA & $2,270.0$ & 691.9 & $1,064.3$ & 324.4 & & \\
\hline ER-5-3\#2 & Tmab & BED & GL/ZE & VTA & TM-WTA & $2,310.0$ & 704.1 & $1,024.3$ & 312.2 & & \\
\hline ER-5-3\#2 & Tmrr & \begin{tabular}{|l|} 
NWT/PWT \\
\end{tabular} & ZE & \begin{tabular}{|l|} 
TCU \\
\end{tabular} & TM-WTA & $2,340.0$ & 713.2 & 994.3 & 303.1 & & \\
\hline ER-5-3\#2 & Tmrr,Tmrp & PWT/MWT & DV/VP & WTA & TM-WTA & $2,370.0$ & 722.4 & 964.3 & 293.9 & & \\
\hline ER-5-3\#2 & Tmrp & MWT/DWT & DV/QC & WTA & TM-WTA & $2,520.0$ & 768.1 & 814.3 & 248.2 & & \\
\hline ER-5-3\#2 & Tmrp & DWT & DV/QC & WTA & TM-WTA & $2,540.0$ & 774.2 & 794.3 & 242.1 & & \\
\hline ER-5-3\#2 & Tmrp & MWT & DV/VP & WTA & TM-WTA & $2,600.0$ & 792.5 & 734.3 & 223.8 & & \\
\hline ER-5-3\#2 & Tmrp & PWT/NWT & DV/ZE & VTA & TM-LVTA & $2,710.0$ & 826.0 & 624.3 & 190.3 & & \\
\hline ER-5-3\#2 & Tmrp & NWT & ZE & TCU & UTCU & $2,780.0$ & 853.4 & 554.3 & 169.0 & & \\
\hline ER-5-3\#2 & Tmrh & BED & ZE & $\mathrm{TCU}$ & UTCU & $2,807.0$ & 855.6 & 527.3 & 160.7 & & \\
\hline
\end{tabular}


Appendix A.

Hydrostratigraphic Database for Drill Holes in the Frenchman Flat Area.

Page 2 of 8

\begin{tabular}{|c|c|c|c|c|c|c|c|c|c|c|c|}
\hline Hole Name & Strat $^{1}$ & Lith $^{1}$ & Major Alter. ${ }^{1}$ & $H G U^{2}$ & $\mathrm{HSU}^{3}$ & $\begin{array}{l}\text { Depth } \\
\text { Top }^{4}(\mathrm{ft})\end{array}$ & $\begin{array}{c}\text { Depth } \\
\text { Top }^{4}(\mathrm{~m})\end{array}$ & $\begin{array}{c}\text { Elev. Top } \\
\text { (ft) }\end{array}$ & $\begin{array}{c}\text { Elev. Top } \\
(\mathrm{m})\end{array}$ & $\mathrm{TD}^{6}(\mathrm{ft})$ & $\operatorname{TD}^{6}(\mathrm{~m})$ \\
\hline ER-5-3\#2 & Tpt & NWT & GL & WTA & TSA & $2,862.0$ & 872.3 & 472.3 & 144.0 & & \\
\hline ER-5-3\#2 & Tpt & MWT/DWT & DV/QTZ/VP & WTA & TSA & $2,891.0$ & 881.2 & 443.3 & 135.1 & & \\
\hline ER-5-3\#2 & Tpt & PWT & DV/QZ/ZE & WTA & TSA & $2,960.0$ & 902.2 & 374.3 & 114.1 & & \\
\hline ER-5-3\#2 & Tpt & NWT & DV/GL/ZE & VTA & TSA & $3,000.0$ & 914.4 & 334.3 & 101.9 & & \\
\hline ER-5-3\#2 & Th & BED & ZE & TCU & LTCU & $3,024.0$ & 921.7 & 310.3 & 94.6 & & \\
\hline ER-5-3\#2 & Twlb & NWT/PWT & ZE & TCU & LTCU & $3,055.0$ & 931.2 & 279.3 & 85.1 & & \\
\hline ER-5-3\#2 & Twlb & BED/NWT/PWT & ZE/QTZ & TCU & LTCU & $3,164.0$ & 964.4 & 170.3 & 51.9 & & \\
\hline ER-5-3\#2 & Twls & BED/NWT/PWT & ZE/CC/QZ & TCU & LTCU & $3,315.0$ & $1,010.4$ & 19.3 & 5.9 & & \\
\hline ER-5-3\#2 & Tcb & BED/NWT/PWT & ZE/CC/QZ & TCU & LTCU & $3,796.0$ & $1,157.0$ & -461.7 & -140.7 & & \\
\hline ER-5-3\#2 & $\mathrm{Pz}$ & DM & CC & CA & LCA & $4,678.0$ & $1,425.9$ & $-1,343.7$ & -409.6 & & \\
\hline ER-5-3\#3 & QTa & $\mathrm{AL}$ & CC/ZE & AA & AA3 & 0.0 & 0.0 & $3,334.3$ & $1,016.0$ & 1,800 & 548.6 \\
\hline ER-5-3\#3 & QTa & $\mathrm{AL}$ & CC/ZE & AAA & OAA & 610.0 & 185.9 & $2,724.3$ & 830.4 & & \\
\hline ER-5-3\#3 & Tybf & BS & DV & LFA & BLFA & 910.0 & 277.4 & $2,424.3$ & 738.9 & & \\
\hline ER-5-3\#3 & QTa & $\overline{\mathrm{AL}}$ & CC/ZE & AAA & OAA1 & 950.0 & 289.6 & $2,384.3$ & 726.7 & & \\
\hline ER-5-4 & QTa & $\overline{A L}$ & CC & AA & AA3 & 0.0 & 0.0 & $3,131.7$ & 954.5 & $3,732.0$ & 1137.5 \\
\hline ER-5-4 & QTp & $\mathrm{P}$ & CC & $\mathrm{PCU}$ & $\mathrm{PCU}_{1 \mathrm{U}^{7}}$ & $2,312.0$ & 704.7 & 819.7 & 249.8 & & \\
\hline ER-5-4 & Ttp & BED & GL & VTA & PCU1U & $2,702.0$ & 823.6 & 429.7 & 131.0 & & \\
\hline ER-5-4 & QTp & $\mathrm{P}$ & $\mathrm{CC}$ & $\mathrm{PCU}$ & PCU1U & $2,707.0$ & 825.1 & 424.7 & 129.5 & & \\
\hline ER-5-4 & QTa & $\mathrm{AL}$ & $\mathrm{CC}$ & AA & AA1 & $2,940.0$ & 869.1 & 191.7 & 58.4 & & \\
\hline ER-5-4 & Tma & PWT & DV & WTA & TM-WTA & $3,670.0$ & $1,118.6$ & -538.3 & 164.1 & & \\
\hline ER-5-4\#2 & QTa & $\mathrm{AL}$ & CC/ZE & AA & AA3 & 0.0 & 0.0 & $3,131.7$ & 954.5 & $7,000.0$ & 2133.6 \\
\hline ER-5-4\#2 & QTp & $\mathrm{P}$ & $\mathrm{CC}$ & PCU & PCU1U & $2,312.0$ & 704.7 & 819.7 & 249.8 & & \\
\hline ER-5-4\#2 & Ttp & BED & GL & VTA & PCU1U & $2,702.0$ & 823.6 & 429.7 & 131.0 & & \\
\hline ER-5-4\#2 & QTp & $\mathrm{P}$ & $\mathrm{CC}$ & PCU & PCU1U & $2,707.0$ & 825.1 & 424.7 & 129.5 & & \\
\hline ER-5-4\#2 & QTa & $\mathrm{AL}$ & $\mathrm{CC}$ & AA & AA1 & $2,940.0$ & 869.1 & 191.7 & 58.4 & & \\
\hline ER-5-4\#2 & Tma & PWT & DV/GL/ZE & VTA & TM-WTA & $3,676.0$ & $1,120.4$ & -544.3 & -165.9 & & \\
\hline ER-5-4\#2 & Tma & MWT & DV & WTA & TM-WTA & $3,730.0$ & $1,136.9$ & -598.3 & -182.4 & & \\
\hline ER-5-4\#2 & Tma & PWT & DV & WTA & TM-WTA & $3,830.0$ & $1,167.4$ & -698.3 & -212.8 & & \\
\hline ER-5-4\#2 & Tma & NWT & GL & VTA & TM-WTA & $3,890.0$ & $1,185.7$ & -758.3 & -231.1 & & \\
\hline ER-5-4\#2 & Tmab & BED & $\mathrm{GL}$ & VTA & TM-WTA & $3,928.0$ & $1,197.3$ & 796.3 & -242.7 & & \\
\hline ER-5-4\#2 & Tmr & NWT & GL/DV & VTA & TM-WTA & $3,980.0$ & $1,213.1$ & -848.3 & -285.6 & & \\
\hline ER-5-4\#2 & Tmr & PWT & DV & WTA & TM-WTA & $4,020.0$ & $1,225.3$ & -888.3 & -270.8 & & \\
\hline ER-5-4\#2 & Tmr & MWT & DV & WTA & TM-WTA & $4,102.0$ & $1,250.3$ & -970.3 & -295.8 & & \\
\hline ER-5-4\#2 & Tmr & PWT & GL & WTA & TM-LVTA & $4,306.0$ & $1,312.5$ & $-1,174.3$ & -357.9 & & \\
\hline ER-5-4\#2 & Tmr & NWT & $\mathrm{GL}$ & VTA & TM-LVTA & 4,320.0 & $1,316.0$ & $-1,188.3$ & -362.2 & & \\
\hline
\end{tabular}


Appendix A.

Hydrostratigraphic Database for Drill Holes in the Frenchman Flat Area.

Page 3 of 8

\begin{tabular}{|c|c|c|c|c|c|c|c|c|c|c|c|}
\hline Hole Name & Strat $^{1}$ & Lith $^{1}$ & Major Alter. $^{1}$ & $H G U^{2}$ & $\mathrm{HSU}^{3}$ & $\begin{array}{c}\text { Depth } \\
\text { Top }^{4}(\mathrm{ft})\end{array}$ & $\begin{array}{c}\text { Depth } \\
\operatorname{Top}^{4}(\mathrm{~m})\end{array}$ & $\begin{array}{c}\text { Elev. Top } \\
\text { (ft) }\end{array}$ & $\begin{array}{c}\text { Elev. Top } \\
(\mathrm{m})\end{array}$ & $\operatorname{TD}^{6}(\mathrm{ft})$ & $\operatorname{TD}^{6}(\mathrm{~m})$ \\
\hline ER-5-4\#2 & $\begin{array}{l}\text { pre-Tmr/ } \\
\text { post-Tw }\end{array}$ & NWT/BED & & VTA & TM-LVTA & $4,356.0$ & $1,327.7$ & $-1,224.3$ & -373.2 & & \\
\hline \begin{tabular}{|l|l} 
ER-5-4\#2 \\
\end{tabular} & Tw & NWT/BED & ZE & TCU & LTCU & $4,472.0$ & $1,363.1$ & $-1,340.3$ & -408.5 & & \\
\hline ER-5-4\#2 & Tw & LA & DV/QZ & $\overline{\text { LFA }}$ & LTCU & $6,072.0$ & $1,850.7$ & $-2,940.3$ & -896.2 & & \\
\hline ER-5-4\#2 & Tw & NWT & ZE & TCU & LTCU & $6,134.0$ & $1,869.6$ & $-3,002.3$ & -915.1 & & \\
\hline ER-5-4\#2 & Tcb & NWT & ZE & TCU & LTCU & $6,306.0$ & $1,922.1$ & $-3,174.3$ & -967.5 & & \\
\hline ER-5-4\#2 & Tw & NWT & ZE & TCU & LTCU & $6,730.0$ & $2,051.3$ & $-3,598.3$ & $-1,096.8$ & & \\
\hline$U-5 a$ & QTa & $A L$ & CC & $\mathrm{AA}$ & $\mathrm{AA}^{9}{ }^{9}$ & 0.0 & 0.0 & $3,086.0$ & 940.6 & 628.0 & 191.4 \\
\hline WW-5A & QTa & $\mathrm{AL}$ & $\mathrm{CC}$ & $\mathrm{AA}$ & AA3 & 0.0 & 0.0 & $3,093.0$ & 942.7 & 910.0 & 277.4 \\
\hline WW-5A & QTp & $\mathrm{P}$ & $\mathrm{CC}$ & $\mathrm{PCU}$ & $\mathrm{PCU} \mathrm{T}^{8}$ & 80.0 & 24.4 & $3,013.0$ & 918.4 & & \\
\hline WW-5A & QTa & $A L$ & CC & AA & AA2 & 550.0 & 167.6 & $2,543.0$ & 775.1 & & \\
\hline WW-5A & QTa & $A L$ & $\mathrm{CC}$ & AA & AA2 & 585.0 & 178.3 & $2,508.0$ & 764.4 & & \\
\hline U-5b & QTa & $A L$ & CC & AA & AA3 & 0.0 & 0.0 & $3,095.0$ & 943.4 & 675.0 & 205.7 \\
\hline WW-5B & QTa & $A L$ & CC & AA & AA3 & 0.0 & 0.0 & $3,092.0$ & 942.4 & 900.0 & 274.3 \\
\hline WW-5B & QTp & $\mathrm{P}$ & & PCU & PCU2T & 57.0 & 17.4 & $3,035.0$ & 925.1 & & \\
\hline WW-5B & QTa & $\widehat{A L}$ & $\mathrm{CC}$ & $\overline{\mathrm{AA}}$ & AA2 & 432.0 & 131.7 & $2,660.0$ & 810.8 & & \\
\hline$U-5 c$ & QTa & $\mid \overline{A L}$ & $\mathrm{CC}$ & $\widehat{A A}$ & AA3 & 0.0 & 0.0 & $3,100.0$ & 944.9 & 675.0 & 205.7 \\
\hline WW-5C & QTa & $\mathrm{AL}$ & $\mathrm{CC}$ & $\overline{\mathrm{AA}}$ & AA3 & 0.0 & 0.0 & $3,081.0$ & 939.1 & $1,200.0$ & 365.8 \\
\hline WW-5C & QTp & $\mathrm{P}$ & & $\mathrm{PCU}$ & PCU2T & 10.0 & 3.5 & $3,071.0$ & 936.0 & & \\
\hline WW-5C & QTa & $\mathrm{AL}$ & CC/QZ & $\mathrm{AA}$ & AA & 732.0 & 223.1 & $2,349.0$ & 716.0 & & \\
\hline UE-5cWW & QTa & $\mathrm{AL}$ & $\mathrm{CC}$ & $\mathrm{AA}$ & AA & 0.0 & 0.0 & $3,216.0$ & 980.2 & $2,682.0$ & 817.5 \\
\hline UE-5cWW & Tw & NWT & ZE & TCU & LTCU & $1,350.0$ & 411.5 & $1,866.0$ & 568.8 & & \\
\hline U-5d & QTa & $A L$ & $\mathrm{CC}$ & AA & AA3 & 0.0 & 0.0 & $3,120.0$ & 951.0 & 685.0 & 208.8 \\
\hline U-5e & QTa & $A L$ & CC & AA & AA3 & 0.0 & 0.0 & $3,137.0$ & 956.2 & $1,000.0$ & 304.8 \\
\hline UE-5f & QTa & $A L$ & CC & AA & AA3 & 0.0 & 0.0 & $3,301.0$ & $1,006.1$ & $1,100.0$ & 335.3 \\
\hline U-5g & QTa & $A L$ & CC & AA & AA3 & 0.0 & 0.0 & 3,085 & 940.3 & 90.0 & 27.4 \\
\hline$U-5 i$ & QTa & $\widehat{A L}$ & $\mathrm{CC}$ & $\overline{\mathrm{AA}}$ & AA3 & 0.0 & 0.0 & $3,395.0$ & 1,034.8 & 820.0 & 249.9 \\
\hline$U-5 i$ & QTa & $A L$ & CC/ZE & AAA & OAA & 550.0 & 167.6 & $2,877.0$ & 876.9 & & \\
\hline UE-5i & QTa & $\widehat{A L}$ & CC & $\overline{\mathrm{AA}}$ & AA2 & 0.0 & 0.0 & $3,427.0$ & \begin{tabular}{ll|}
$1,044.6$ \\
\end{tabular} & $2,124.0$ & 647.4 \\
\hline UE-5i & QTa & $\widehat{A \mathrm{AL}}$ & CC/ZE & AAA & OAA & 550.0 & 167.6 & $2,877.0$ & 876.9 & & \\
\hline UE-5i & Tybf & BS & CC & 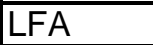 & BLFA & 880.0 & 268.2 & $2,547.0$ & 776.3 & & \\
\hline UE-5i & QTa & $\mathrm{AL}$ & CC/ZE & AAA & OAA1 & 950.0 & 289.6 & $2,477.0$ & 755.0 & & \\
\hline UE-5i & Ttp & NWT & $\mathrm{V}$ & VTA & OAA1 & $1,065.0$ & 324.6 & $2,362.0$ & 719.9 & & \\
\hline UE-5i & QTC & $\mathrm{AL}$ & $\mathrm{CC} / \mathrm{ZE}$ & $\mathrm{AA}$ & OAA1 & $1,090.0$ & 332.2 & $2,337.0$ & 712.3 & & \\
\hline UE-5i & Tma & MWT/DWT & DV & WTA & TM-WTA & $1,100.0$ & 335.3 & $2,327.0$ & 709.3 & & \\
\hline
\end{tabular}


Appendix A.

Hydrostratigraphic Database for Drill Holes in the Frenchman Flat Area.

Page 4 of 8

\begin{tabular}{|c|c|c|c|c|c|c|c|c|c|c|c|}
\hline Hole Name & Strat $^{1}$ & Lith $^{1}$ & Major Alter. ${ }^{1}$ & $\mathrm{HGU}^{2}$ & $\mathrm{HSU}^{3}$ & $\begin{array}{l}\text { Depth } \\
\text { Top }^{4}(\mathrm{ft})\end{array}$ & $\begin{array}{l}\text { Depth } \\
\text { Top }^{4}(\mathrm{~m})\end{array}$ & $\begin{array}{c}\text { Elev. Top } \\
(\mathrm{ft})\end{array}$ & $\begin{array}{c}\text { Elev. Top }{ }^{5} \\
(\mathrm{~m})\end{array}$ & $\operatorname{TD}^{6}(\mathrm{ft})$ & $\mathrm{TD}^{6}(\mathrm{~m})$ \\
\hline UE-5i & Tmab & BED & GL & VTA & TM-WTA & $1,368.0$ & 417.0 & $2,059.0$ & 627.6 & & \\
\hline UE-5i & $\mathrm{Tmr}$ & NWT & $\mathrm{V}$ & VTA & TM-WTA & $1,398.0$ & 426.1 & $2,029.0$ & 618.4 & & \\
\hline UE-5i & $\mathrm{Tmr}$ & DWT & DV & WTA & TM-WTA & $1,700.0$ & 518.2 & $1,727.0$ & 526.4 & & \\
\hline UE-5i & Tmr & PWT/NWT & V & VTA & TM-LVTA & $2,010.0$ & 612.6 & $1,417.0$ & 431.9 & & \\
\hline UE-5i & $\mathrm{Tmr}$ & NWT & ZE & TCU & UTCU & $2,040.0$ & 621.8 & $1,387.0$ & 422.8 & & \\
\hline UE-5i & Tmrh/Ta & BED & ZE & TCU & UTCU & $2,120.0$ & 646.2 & $1,307.0$ & 398.4 & & \\
\hline U-5i\#1 & QTa & $A L$ & $\mathrm{CC}$ & AA & AA3 & 0.0 & 0.0 & $3,404.0$ & $1,037.5$ & 835.0 & 254.5 \\
\hline UE-5j & QTa & $A L$ & $\mathrm{CC}$ & AA & AA3 & 0.0 & 0.0 & $3,578.0$ & $1,090.6$ & $1,242.0$ & 378.6 \\
\hline UE-5j & Tma & DWT & DV & WTA & TM-WTA & $1,090.0$ & 332.0 & $2,488.0$ & 758.3 & & \\
\hline UE-5j & Tmr & MWT & DV & WTA & TM-WTA & $1,235.0$ & 376.4 & $2,343.0$ & 714.2 & & \\
\hline U-5k & QTa & $A L$ & $\mathrm{CC}$ & AA & AA3 & 0.0 & 0.0 & $3,349.0$ & $1,020.8$ & 905.0 & 275.8 \\
\hline U-5k & QTa & $A L$ & $\mathrm{CC} / \mathrm{ZE}$ & AAA & OAA & 575.0 & 175.0 & $2,774.0$ & 845.5 & & \\
\hline UE-5k & QTa & $A L$ & $\mathrm{CC}$ & AA & AA3 & 0.0 & 0.0 & $3,349.0$ & $1,020.8$ & $1,728.0$ & 526.7 \\
\hline UE-5k & QTa & $A L$ & CC/ZE & AAA & OAA & 575.0 & 175.3 & $2,774.0$ & 845.5 & & \\
\hline UE-5k & Tybf & BS & & LFA & BLFA & 950.0 & 289.6 & $2,399.0$ & 731.2 & & \\
\hline UE-5k & QTa & $A L$ & $\mathrm{CC} / \mathrm{ZE}$ & AAA & OAA1 & $1,000.0$ & 304.8 & $2,349.0$ & 716.0 & & \\
\hline UE-5k & Tma & DWT & DV & WTA & TM-WTA & $1,660.0$ & 506.0 & $1,689.0$ & 514.8 & & \\
\hline U-5L & QTa & $A L$ & $\mathrm{CC}$ & AA & AA3 & 0.0 & 0.0 & $3,323.0$ & $1,012.9$ & 120 & 36.6 \\
\hline U-5Ls & QTa & $A L$ & $\mathrm{CC}$ & AA & AA3 & 0.0 & 0.0 & $3,324.0$ & $1,013.2$ & 835.0 & 254.5 \\
\hline UE-5m & QTa & $\mathrm{AL}$ & $\mathrm{CC}$ & AA & AA3 & 0.0 & 0.0 & $3,500.0$ & $1,066.8$ & $1,504.0$ & 458.4 \\
\hline UE-5m & Tw & NWT/BED & ZE & TCU & WCU & 165.0 & 50.3 & $3,335.0$ & $1,016.5$ & & \\
\hline UE-5m & Tws & FB & & LFA & WCU & 430.0 & 131.1 & $3,070.0$ & 935.7 & & \\
\hline UE-5m & Tc & TUF & ZE & TCU & LTCU $^{13}$ & $1,100.0$ & 335.3 & $2,400.0$ & 731.5 & & \\
\hline UE-5m & Tgp & TUF/SS & AR & TCU/AA/CA & VCU & $1,280.0$ & 390.1 & $2,220.0$ & 676.7 & & \\
\hline UE-5n & QTa & $A L$ & $\mathrm{CC}$ & AA & AA3 & 0.0 & 0.0 & $3,112.0$ & 948.5 & $1,687.0$ & 514.2 \\
\hline RNM\#1 & QTa & $A L$ & $\mathrm{CC}$ & AA & AA3 & 0.0 & 0.0 & $3,136.0$ & 955.9 & $1,302.0$ & 396.8 \\
\hline RNM\#2 & QTa & $A L$ & $\mathrm{CC}$ & AA & AA3 & 0.0 & 0.0 & $3,132.0$ & 954.6 & 935.0 & 285.0 \\
\hline RNM\#2s & QTa & $A L$ & $\mathrm{CC}$ & AA & AA3 & 0.0 & 0.0 & $3,133.0$ & 954.9 & $1,156.0$ & 352.3 \\
\hline RNM\#3 & QTa & $A L$ & $\mathrm{CC}$ & AA & AA3 & 0.0 & 0.0 & $\mathrm{NA}$ & $\mathrm{NA}$ & 100.0 & 30.5 \\
\hline RNM\#4 & QTa & $A L$ & $\mathrm{CC}$ & AA & AA3 & 0.0 & 0.0 & $\mathrm{NA}$ & $\mathrm{NA}$ & 72.0 & 21.9 \\
\hline RNM\#5 & QTa & $A L$ & $\mathrm{CC}$ & AA & AA3 & 0.0 & 0.0 & $3,111.0$ & 948.2 & 150.0 & 45.7 \\
\hline U5Rc1 & QTa & $A L$ & $\mathrm{CC}$ & AA & AA3 & 0.0 & 0.0 & NA & NA & 46.0 & 14.0 \\
\hline U5R4c & QTa & $A L$ & CC & AA & AA3 & 0.0 & 0.0 & $\mathrm{NA}$ & $\mathrm{NA}$ & 118.0 & 36.0 \\
\hline U5R5 & QTa & $A L$ & $\mathrm{CC}$ & AA & AA3 & 0.0 & 0.0 & NA & $\mathrm{NA}$ & 55.0 & 16.8 \\
\hline U5R5u & QTa & $A L$ & $\mathrm{CC}$ & AA & AA3 & 0.0 & 0.0 & NA & NA & 118.0 & 36.0 \\
\hline
\end{tabular}


Appendix A.

Hydrostratigraphic Database for Drill Holes in the Frenchman Flat Area.

Page 5 of 8

\begin{tabular}{|c|c|c|c|c|c|c|c|c|c|c|c|}
\hline Hole Name & Strat $^{1}$ & Lith $^{1}$ & Major Alter. ${ }^{1}$ & $\mathrm{HGU}^{2}$ & $\mathrm{HSU}^{3}$ & $\begin{array}{l}\text { Depth } \\
\text { Top }^{4}(\mathrm{ft})\end{array}$ & $\begin{array}{c}\text { Depth } \\
\text { Top }^{4}(\mathrm{~m})\end{array}$ & $\begin{array}{c}\text { Elev. Top } \\
\text { (ft) }\end{array}$ & $\begin{array}{c}\text { Elev. Top } \\
\text { (m) }\end{array}$ & $\operatorname{TD}^{6}(\mathrm{ft})$ & $\operatorname{TD}^{6}(\mathrm{~m})$ \\
\hline U5R6u & QTa & $A L$ & $\mathrm{CC}$ & AA & AA3 & 0.0 & 0.0 & NA & NA & 117.0 & 35.7 \\
\hline U5R7c & QTa & $A L$ & $\mathrm{CC}$ & AA & AA3 & 0.0 & 0.0 & $3,195.0$ & 973.8 & 120.0 & 36.6 \\
\hline U5R8c & QTa & $A L$ & $\mathrm{CC}$ & AA & AA3 & 0.0 & 0.0 & $3,194.0$ & 973.5 & 120.0 & 36.6 \\
\hline U5R9u & QTa & $A L$ & $\mathrm{CC}$ & AA & AA3 & 0.0 & 0.0 & $3,190.0$ & 972.3 & 120.0 & 36.6 \\
\hline U5R10u & QTa & $\mathrm{AL}$ & $\mathrm{CC}$ & AA & AA3 & 0.0 & 0.0 & $3,190.0$ & 972.3 & 117.0 & 35.7 \\
\hline U5R11u & QTa & $A L$ & $\mathrm{CC}$ & AA & AA3 & 0.0 & 0.0 & $\mathrm{NA}$ & NA & 119.0 & 36.3 \\
\hline U5R12u & QTa & $A L$ & $\mathrm{CC}$ & AA & AA3 & 0.0 & 0.0 & NA & NA & 119.0 & 36.3 \\
\hline RCRA\#1 & QTa & $A L$ & $\mathrm{CC}$ & AA & AA3 & 0.0 & 0.0 & $\mathrm{NA}$ & NA & 120.0 & 36.6 \\
\hline TH5\#4 & QTa & $A L$ & $\mathrm{CC}$ & AA & AA3 & 0.0 & 0.0 & $3,405.0$ & $1,037.8$ & 172.0 & 52.4 \\
\hline TH5\#4 & Tw & FB/LA & & $\mathrm{TCU}$ & WCU & 129.0 & 39.3 & $3,276.0$ & 998.5 & & \\
\hline TH5\#5 & QTa & $A L$ & $\mathrm{CC}$ & AA & AA3 & 0.0 & 0.0 & $3,233.0$ & 985.4 & 461.0 & 140.5 \\
\hline TH5\#5 & Tw & FB/LA & AR & TCU/LFA & WCU & 134.0 & 40.8 & $3,099.0$ & 944.6 & & \\
\hline U5GCDT1 & QTa & $A L$ & $\mathrm{CC}$ & AA & AA3 & 0.0 & 0.0 & $3,242.0$ & 988.2 & 119.0 & 36.3 \\
\hline TH5\#1 & QTa & $A L$ & $\mathrm{CC}$ & $\mathrm{AA}$ & AA3 & 0.0 & 0.0 & $3,178.0$ & 968.7 & 60 & 18.3 \\
\hline TH5\#1A & QTa & $A L$ & $\mathrm{CC}$ & AA & AA3 & 0.0 & 0.0 & $\mathrm{NA}$ & NA & 120.0 & 36.6 \\
\hline TH5\#2 & QTa & $A L$ & $\mathrm{CC}$ & AA & AA3 & 0.0 & 0.0 & $3,188.0$ & 971.7 & 86 & 26.2 \\
\hline UE-5PW-1 & QTa & $\mathrm{AL}$ & $\mathrm{CC}$ & AA & AA3 & 0.0 & 0.0 & $3,180.0$ & 969.3 & 839.0 & 255.7 \\
\hline UE-5PW-2 & QTa & $A L$ & $\mathrm{CC}$ & AA & AA3 & 0.0 & 0.0 & $3,248.0$ & 990.0 & 919.5 & 280.3 \\
\hline UE-5PW-3 & QTa & $A L$ & $\mathrm{CC}$ & AA & AA3 & 0.0 & 0.0 & $3,298.0$ & $1,005.2$ & 955.0 & 291.1 \\
\hline UE-5PW-3 & Tma & PWT & V & WTA & TM-WTA & 617.0 & 188.1 & $2,681.0$ & 817.2 & & \\
\hline UE-5PW-3 & Tmab & BED & $\mathrm{V}$ & VTA & TM-WTA & 917.0 & 279.5 & $2,381.0$ & 725.7 & & \\
\hline UE-5PW-3 & Tmr & PWT & DV & WTA & TM-WTA & 955.0 & 291.1 & $2,343.0$ & 714.2 & & \\
\hline SB5 AP1 & QTa & $A L$ & $\mathrm{CC}$ & AA & AA3 & 0.0 & 0.0 & $3,199.5$ & 975.2 & 275.0 & 83.8 \\
\hline SB5 AP2 & QTa & $A L$ & $\mathrm{CC}$ & AA & AA3 & 0.0 & 0.0 & $3,199.3$ & 975.2 & 275.0 & 83.8 \\
\hline SB5 RP1 & QTa & $A L$ & $\mathrm{CC}$ & AA & AA3 & 0.0 & 0.0 & $3,169.3$ & 966.0 & 150.0 & 45.7 \\
\hline SB5 RP2 & QTa & $A L$ & $\mathrm{CC}$ & AA & AA3 & 0.0 & 0.0 & $3,169.1$ & 965.9 & 150.0 & 45.7 \\
\hline SB5 NN1 & QTa & $A L$ & $\mathrm{CC}$ & AA & AA3 & 0.0 & 0.0 & $3,204.9$ & 976.9 & 200.0 & 61.0 \\
\hline SB5 NE1 & QTa & $A L$ & $\mathrm{CC}$ & AA & AA3 & 0.0 & 0.0 & $3,196.6$ & 974.3 & 200.0 & 61.0 \\
\hline SB5 NW1 & QTa & $A L$ & $\mathrm{CC}$ & AA & AA3 & 0.0 & 0.0 & $3,177.7$ & 968.6 & 200.0 & 61.0 \\
\hline SB5 NS1 & QTa & $A L$ & $\mathrm{CC}$ & AA & AA3 & 0.0 & 0.0 & $3,171.2$ & 966.6 & 200.0 & 61.0 \\
\hline WW6-4 & QTa & $A L$ & $\mathrm{CC}$ & AA & AA3 & 0.0 & 0.0 & $3,602.0$ & $1,097.9$ & $1,479.0$ & 450.8 \\
\hline WW6-4 & Tma & MWT/DWT & DV & WTA & TM-WTA & 520.0 & 158.5 & $3,082.0$ & 939.4 & & \\
\hline WW6-4 & $\mathrm{Tmr}$ & NWT & GL/DV & VTA & TM-WTA & 740.0 & 225.6 & $2,862.0$ & 872.3 & & \\
\hline WW6-4 & Tmr & MWT & DV & WTA & TM-WTA & 790.0 & 240.8 & $2,812.0$ & 857.1 & & \\
\hline WW6-4 & Tmr & DWT & DV & WTA & TM-WTA & 940.0 & 286.5 & $2,662.0$ & 811.4 & & \\
\hline
\end{tabular}


Appendix A.

Hydrostratigraphic Database for Drill Holes in the Frenchman Flat Area.

Page 6 of 8

\begin{tabular}{|c|c|c|c|c|c|c|c|c|c|c|c|}
\hline Hole Name & Strat $^{1}$ & Lith $^{1}$ & Major Alter. ${ }^{1}$ & $\mathrm{HGU}^{2}$ & $\mathrm{HSU}^{3}$ & $\begin{array}{l}\text { Depth } \\
\text { Top }^{4}(\mathrm{ft})\end{array}$ & $\begin{array}{c}\text { Depth } \\
\text { Top }^{4}(\mathrm{~m})\end{array}$ & $\begin{array}{c}\text { Elev. Top } \\
\text { (ft) }\end{array}$ & $\begin{array}{c}\text { Elev. Top } \\
\text { (m) }\end{array}$ & $\operatorname{TD}^{6}(\mathrm{ft})$ & $\operatorname{TD}^{6}(\mathrm{~m})$ \\
\hline WW6-4 & Tmr & MWT & DV & WTA & TM-WTA & $1,060.0$ & 323.1 & $2,542.0$ & 774.8 & & \\
\hline WW6-4 & Tmr & NWT & $\mathrm{GL}$ & VTA & TM-LVTA & $1,190.0$ & 362.7 & $2,412.0$ & 735.2 & & \\
\hline WW6-4 & Tmrh/Ta & RWT & DV & VTA & TM-LVTA & $1,210.0$ & 368.8 & $2,392.0$ & 729.1 & & \\
\hline WW6-4 & Tpt & MWT/DWT & GL/VP/VT & WTA & TSA & $1,250.0$ & 381.0 & $2,352.0$ & 716.9 & & \\
\hline WW6-4 & Th & RWT/NWT/PWT & ZE & TCU & LTCU & $1,340.0$ & 408.4 & $2,262.0$ & 689.5 & & \\
\hline WW6-4A & QTa & $A L$ & $\mathrm{CC}$ & $\mathrm{AA}$ & AA3 & 0.0 & 0.0 & $3,606.0$ & $1,099.1$ & $1,516.0$ & 462.1 \\
\hline WW6-4A & Tma & PWT/MWT & $\mathrm{GL}$ & WTA & TM-WTA & 765.0 & 233.2 & $2,841.0$ & 865.9 & & \\
\hline WW6-4A & Tmab & BED & $\mathrm{GL}$ & VTA & TM-WTA & 970.0 & 295.7 & $2,636.0$ & 803.5 & & \\
\hline WW6-4A & Tmr & NWT & $\mathrm{GL}$ & WTA & TM-WTA & 980.0 & 298.7 & 2,626 & 800.4 & & \\
\hline WW6-4A & Tmr & MWT & $\mathrm{GL}$ & WTA & TM-WTA & $1,050.0$ & 320.0 & 2,556 & 779.1 & & \\
\hline WW6-4A & Tmr & DWT & $\mathrm{GL}$ & WTA & TM-WTA & $1,160.0$ & 353.6 & 2,446 & 745.5 & & \\
\hline WW6-4A & Tmr & MWT & $\mathrm{GL}$ & WTA & TM-WTA & $1,255.0$ & 382.5 & 2,351 & 716.6 & & \\
\hline WW6-4A & Tmr & NWT & $\mathrm{GL}$ & VTA & TM-LVTA & $1,270.0$ & 387.1 & 2,336 & 712.0 & & \\
\hline WW6-4A & Tmrh/Th & BED & $\mathrm{GL}$ & VTA & TM-LVTA & $1,305.0$ & 397.8 & $2,301.0$ & 701.3 & & \\
\hline WW6-4A & Tpt & DWT & $\mathrm{GL}$ & WTA & TSA & $1,325.0$ & 403.9 & $2,281.0$ & 695.3 & & \\
\hline WW6-4A & Th & BED & ZE & TCU & LTCU & $1,450.0$ & 442.0 & $2,156.0$ & 657.2 & & \\
\hline UE-11a & QTa & $A L$ & $\mathrm{CC}$ & $A A$ & AA3 & 0.0 & 0.0 & $3,547.0$ & $1,081.1$ & $1,400.0$ & 426.7 \\
\hline UE-11a & Tma & DWT & DV & WTA & TM-WTA & 550.0 & 167.6 & $2,997.0$ & 913.5 & & \\
\hline UE-11a & Tma & PWT & DV & WTA & TM-WTA & 765.0 & 233.2 & $2,782.0$ & 848.0 & & \\
\hline UE-11a & Tma & NWT & $\mathrm{GL}$ & VTA & TM-WTA & 850.0 & 259.1 & $2,697.0$ & 822.1 & & \\
\hline UE-11a & Tmab & BED & $\mathrm{GL}$ & VTA & TM-WTA & 890.0 & 271.3 & $2,657.0$ & 809.9 & & \\
\hline UE-11a & Tmr & NWT & $\mathrm{GL}$ & VTA & TM-WTA & 900.0 & 274.3 & $2,647.0$ & 806.8 & & \\
\hline UE-11a & Tmr & PWT & DV & WTA & TM-WTA & 950.0 & 289.6 & $2,597.0$ & 791.6 & & \\
\hline UE-11a & Tmr & DWT & DV & WTA & TM-WTA & $1,128.0$ & 343.8 & $2,419.0$ & 737.3 & & \\
\hline UE-11a & Tmr & PWT & DV & WTA & TM-WTA & $1,140.0$ & 347.5 & $2,407.0$ & 733.7 & & \\
\hline $\mathrm{U}-11 \mathrm{~b}$ & QTa & $A L$ & $\mathrm{CC}$ & $\mathrm{AA}$ & AA3 & 0.0 & 0.0 & $3,586.0$ & $1,093.0$ & 980.0 & 298.7 \\
\hline $\mathrm{U}-11 \mathrm{~b}$ & $\mathrm{Tmr}$ & PWT/DWT & DV & WTA & TM-WTA & 190.0 & 57.9 & $3,396.0$ & $1,035.1$ & & \\
\hline$U-11 b$ & Tmrh/Th & BED & $\mathrm{GL}$ & VTA & TM-LVTA & 630.0 & 192.0 & $2,956.0$ & 901.0 & & \\
\hline $\mathrm{U}-11 \mathrm{~b}$ & $\mathrm{Tp}$ & BED & $\mathrm{GL}$ & VTA & TM-LVTA & 978.0 & 298.1 & $2,608.0$ & 794.9 & & \\
\hline UE-11b & QTa & $A L$ & $\mathrm{CC}$ & AA & AA3 & 0.0 & 0.0 & $3,586.0$ & $1,093.0$ & $1,303.0$ & 397.2 \\
\hline UE-11b & Tmr & PWT & DV & WTA & TM-WTA & 190.0 & 57.9 & $3,396.0$ & $1,035.1$ & & \\
\hline UE-11b & Tmr & DWT & DV & WTA & TM-WTA & 260.0 & 79.3 & $3,326.0$ & $1,013.8$ & & \\
\hline UE-11b & $\mathrm{Tmr}$ & NWT & $\mathrm{GL}$ & VTA & TM-LVTA & 515.0 & 157.0 & $3,071.0$ & 936.0 & & \\
\hline UE-11b & Tmrh/Ta & BED & GL & VTA & TM-LVTA & 630.0 & 192.0 & $2,956.0$ & 901.0 & & \\
\hline UE-11b & Tp & BED & $G L$ & VTA & TM-LVTA & 978.0 & 298.1 & $2,608.0$ & 794.9 & & \\
\hline
\end{tabular}


Appendix A.

Hydrostratigraphic Database for Drill Holes in the Frenchman Flat Area.

Page 7 of 8

\begin{tabular}{|c|c|c|c|c|c|c|c|c|c|c|c|}
\hline Hole Name & Strat $^{1}$ & Lith $^{1}$ & Major Alter. ${ }^{1}$ & $\mathrm{HGU}^{2}$ & $\mathrm{HSU}^{3}$ & $\begin{array}{l}\text { Depth } \\
\text { Top }^{4}(\mathrm{ft})\end{array}$ & $\begin{array}{c}\text { Depth } \\
\text { Top }^{4}(\mathrm{~m})\end{array}$ & $\begin{array}{c}\text { Elev. Top } \\
(\mathrm{ft})\end{array}$ & $\begin{array}{c}\text { Elev. Top } \\
\text { (m) }\end{array}$ & $\operatorname{TD}^{6}(\mathrm{ft})$ & $\operatorname{TD}^{6}(\mathrm{~m})$ \\
\hline UE-11b & Tpt & VT/ DWT & GL/DV & WTA & TSA & $1,020.0$ & 310.9 & $2,566.0$ & 782.1 & & \\
\hline UE-11b & Th & BED & $\mathrm{GL}$ & VTA & LVTA & $1,240.0$ & 378 & $2,346.0$ & 715.1 & & \\
\hline UE-11b & Th & BED & ZE & TCU & LTCU & $1,290.0$ & 393.2 & $2,296.0$ & 699.8 & & \\
\hline U-11c & QTa & $A L$ & $\mathrm{CC}$ & $\mathrm{AA}$ & AA3 & 0.0 & 0.0 & $3,381.0$ & $1,030.5$ & 835.0 & 254.5 \\
\hline U-11c & QTa & $\mathrm{AL}$ & $\mathrm{CC} / \mathrm{ZE}$ & AAA & OAA & 650.0 & 198.1 & $2,731.0$ & 832.4 & & \\
\hline$U-11 c \# 1^{14}$ & QTa & $A L$ & CC & AA & AA3 & 0.0 & 0 & $3,380.0$ & 1030.2 & $1,860.0$ & 566.9 \\
\hline U-11c\#1 & QTa & $A L$ & $\mathrm{CC}$ & $A A$ & AA3 & 519.0 & 158.2 & $2,861.0$ & 872.0 & & \\
\hline U-11c\#1 & QTa & $A L$ & $\mathrm{CC} / \mathrm{ZE}$ & AAA & OAA & 680.0 & 207.3 & $2,700.0$ & 823.0 & & \\
\hline U-11c\#1 & Tma & DWT & DV & WTA & TM-WTA & $1,590.0$ & 484.6 & $1,790.0$ & 545.6 & & \\
\hline U-11d & QTa & $A L$ & $\mathrm{CC}$ & $A A$ & AA3 & 0.0 & 0.0 & 3,385 & $1,031.80$ & 40 & 12.2 \\
\hline U-11e & QTa & $A L$ & $\mathrm{CC}$ & $A A$ & AA3 & 0.0 & 0.0 & $3,385.0$ & $1,031.8$ & 835.0 & 254.5 \\
\hline U-11f & QTa & $A L$ & $\mathrm{CC}$ & $\mathrm{AA}$ & AA3 & 0.0 & 0.0 & $3,393.0$ & $1,034.2$ & 910.0 & 277.4 \\
\hline U-11g & QTa & $A L$ & $\mathrm{CC}$ & $A A$ & AA3 & 0.0 & 0.0 & $3,405.0$ & $1,037.8$ & 910.0 & 277.4 \\
\hline U-11g & QTa & $A L$ & $\mathrm{CC} / \mathrm{ZE}$ & AAA & OAA & 570.0 & 173.7 & $2,835.0$ & 864.1 & & \\
\hline U-11g\#1 & QTa & $A L$ & $\mathrm{CC}$ & $\mathrm{AA}$ & AA2 & 0.0 & 0.0 & $3,405.0$ & $1,037.8$ & 860.0 & 262.1 \\
\hline U-11g\#1 & QTa & $A L$ & $\mathrm{CC} / \mathrm{ZE}$ & AAA & OAA & 610.0 & 185.9 & $2,795.0$ & 851.9 & & \\
\hline U-11g Ex1 & QTa & $\mathrm{AL}$ & $\mathrm{CC}$ & $\mathrm{AA}$ & AA3 & 0.0 & 0.0 & $3,405.0$ & $1,037.0$ & $1,155.0$ & 352.0 \\
\hline U-11g Ex1 & QTa & $A L$ & $\mathrm{CC} / \mathrm{ZE}$ & AAA & OAA & 617.0 & 188.1 & $2,788.0$ & 849.8 & & \\
\hline U-11g Ex1 & Tmr & DWT & DV/VP & WTA & TM-WTA & $1,120.0$ & 341.4 & $2,285.0$ & 696.5 & & \\
\hline TW-F & Tw & TUF & AR & TCU & WCU & 0.0 & 0.0 & $4,143.0$ & $1,262.8$ & $3,400.0$ & 1036.3 \\
\hline TW-F & Tws & TUF & AR & TCU & WCU & $1,110.0$ & 338.3 & $3,033.0$ & 924.5 & & \\
\hline TW-F & Tc & BED & ZE & TCU & LTCU & $1,482.0$ & 451.7 & $2,661.0$ & 811.1 & & \\
\hline TW-F & Tgp & SLT & AR & TCU/AA & VCU & 1708 & 520.6 & $2,435.0$ & 742.2 & & \\
\hline TW-F & $\mathrm{Pz}$ & $\mathrm{CA}$ & & $\mathrm{CA}$ & LCA & 3137 & 956.0 & 1006 & 306.6 & & \\
\hline WW-1 & QTa & $A L$ & $\mathrm{CC}$ & $A A$ & AA3 & 0.0 & 0.0 & $3,100.0$ & 944.9 & 870.0 & 265.2 \\
\hline WW-1 & QTp & $\mathrm{P}$ & $\mathrm{CC}$ & $\mathrm{PCU}$ & PCU2T & 20.0 & 6.1 & $3,080.0$ & 938.8 & & \\
\hline WW-1 & QTa & $A L$ & $\mathrm{CC}$ & AA & AA2 & 519.0 & 158.2 & $2,581.0$ & 786.7 & & \\
\hline HTH\#3 & QTa & $A L$ & $\mathrm{CC}$ & $A A$ & AA3 & 0 & 0.0 & $3,477.0$ & $1,059.8$ & $1,860.0$ & 566.9 \\
\hline HTH\#3 & Op & LS & & $\mathrm{CA}$ & LCA & 157 & 47.9 & 3320 & $1,011.9$ & & \\
\hline
\end{tabular}




\section{Appendix A. \\ Hydrostratigraphic Database for Drill Holes in the Frenchman Flat Area. \\ Page 8 of 8}

\section{Explanation:}

Strat $=$ Stratigraphic unit. See Table 4-1 in the main document for abbreviations.

Lith = Lithology

$\begin{array}{ll}\mathrm{AL}=\text { alluvium } & \mathrm{P}=\text { playa } \\ \mathrm{BS}=\text { basalt } & \mathrm{PWT}=\text { partially welded tuff } \\ \mathrm{BED} \text { = bedded tuff } & \text { RWT = reworked tuff } \\ \text { DM = dolomite } & \mathrm{SLT}=\text { siltstone } \\ \text { DWT = densely welded tuff } & \text { TS = tuffaceous sandstone } \\ \text { FB }=\text { flow breccia } & \text { TUF = tuff } \\ \text { LA = lava } & \text { unk = unknown } \\ \text { MWT = moderately welded tuff } & \text { VT = vitrophyric tuff } \\ \text { NWT = nonwelded tuff } & \text { LS = limestone }\end{array}$

Major Alteration

$\begin{array}{ll}\mathrm{AR}=\text { argillic } & \mathrm{QZ}=\text { silicic } \\ \mathrm{CC}=\text { calcite } & \text { unk }=\text { unknown } \\ \mathrm{DM}=\text { dolomite } & \text { VP }=\text { vapor phase } \\ \mathrm{DV}=\text { devitrified } & \mathrm{ZE}=\text { zeolitic }\end{array}$

1 Stratigraphic assignments, lithology, and major alteration compiled from Drellack (1997) and well-specific completion reports. See Section 2 of main document.

2 HGU = Hydrogeologic unit. See Table 4-3 in the main document for abbreviations.

$3 \mathrm{HSU}=$ Hydrostratigraphic unit. See Table 4-4 in the main document for abbreviations.

4 Depth Top = Distance from ground surface to top of unit.

5 Elev. Top = Elevation (above mean sea level) of unit top.

$6 \mathrm{TD}=$ Hole total depth below ground level.

7 PCU1U = Older subsurface playa deposits

8 PCU2T = Youngest (at surface) playa deposits.

9 AA3 = Alluvial deposits overlying the subsurface extension of the modern playa (PCU2). Equivalent to the AA. Refer to Figure 4-7.

$10 \mathrm{AA} 2$ = Alluvial deposits overlying the OAA. Equivalent to the AA. Refer to Figure 4-10.

$11 \mathrm{AA} 1=$ Alluvial deposits beneath older playa (PCU1U). Equivalent to the AA. Refer to Figure 4-7.

12 OAA1 = Older alluvial deposits beneath the basalt lava flow aquifer (BLFA). Equivalent to the OAA. Refer to Figure 4-10.

13 LTCU1 = Zeolitic bedded tuffs (TCU) beneath the WCU. Equivalent to the LTCU. Refer to Figure 4-20.

$14 \mathrm{U}-11 \mathrm{c} \# 1$ = Also called UE-11c. 


\section{APPENDIX B}

Graphical Presentations for Selected UGTA Wells in the Frenchman Flat Model Area

Showing Stratigraphy, Lithology, Alteration, and Hydrogeologic Units

B-1 Well ER-5-3\#2

B-2 Well ER-5-4\#2 


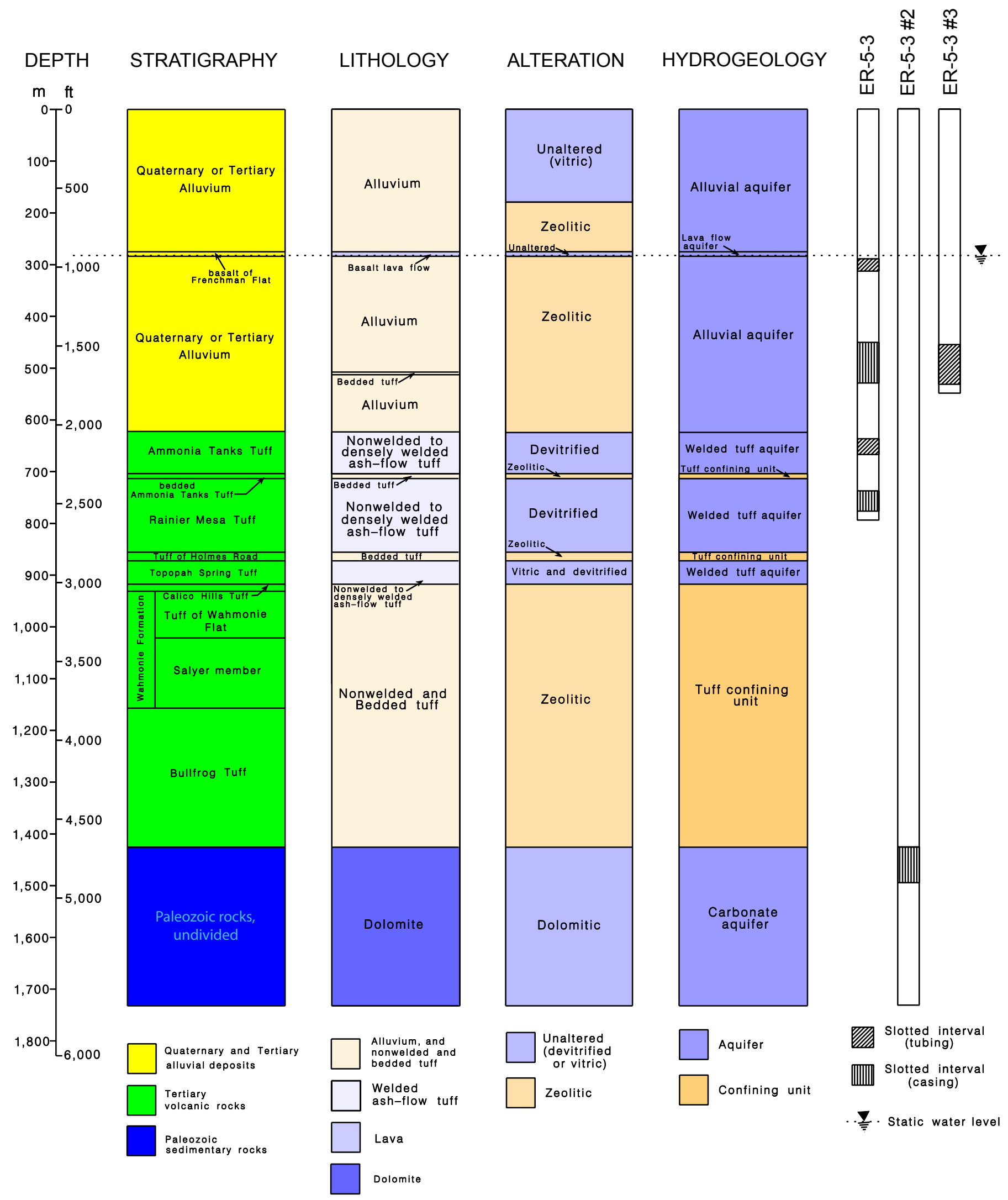

Figure B-1 Geology and Hydrogeology of Well Cluster ER-5-3 


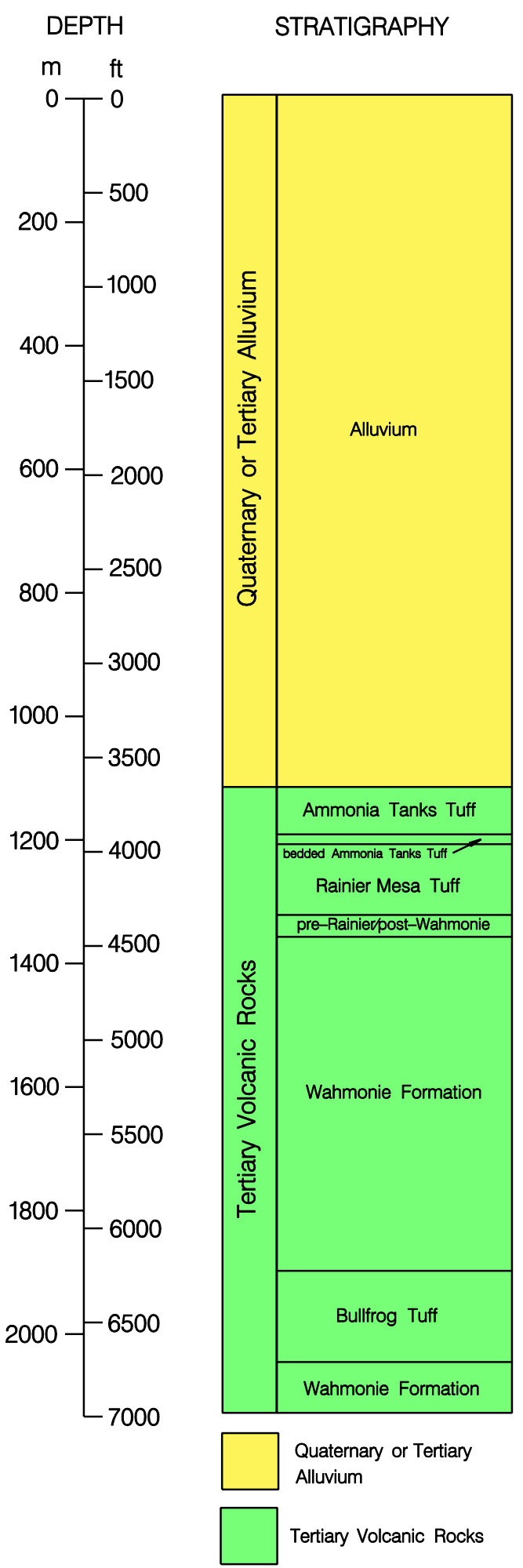

\section{LITHOLOGY}

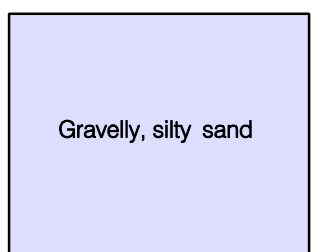

Sand and gravelly sand
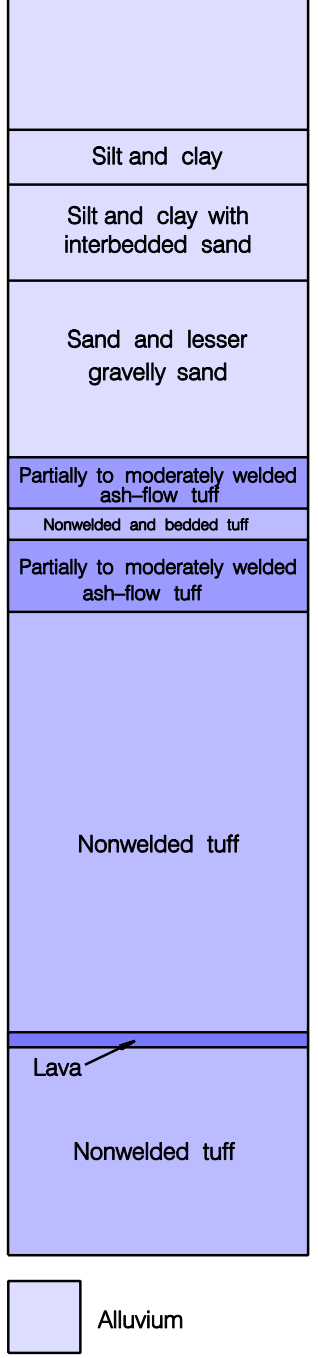

Alluvium

Nonwelded and bedded tuff

Welded

ash-flow tuff

Lava
ALTERATION

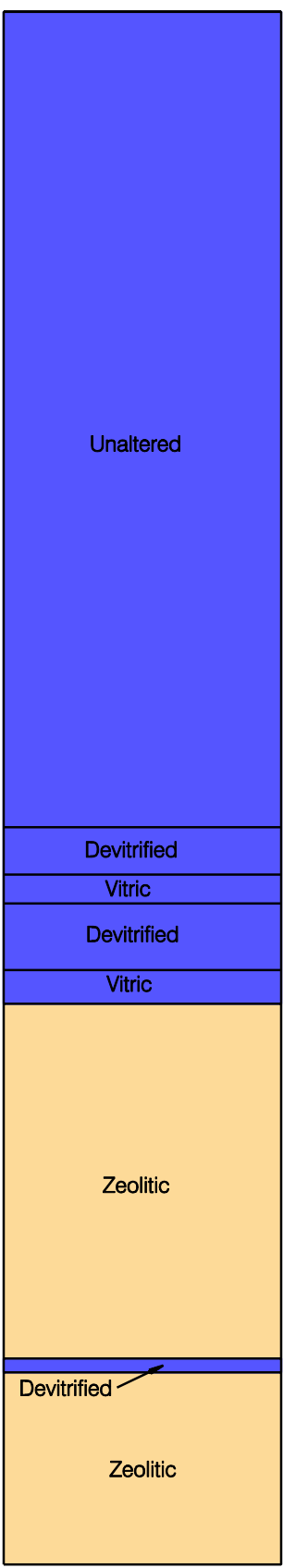

Unaltered

(vitric or devitrified)

Altered (zeolitic)

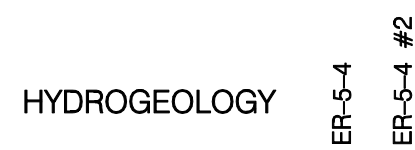
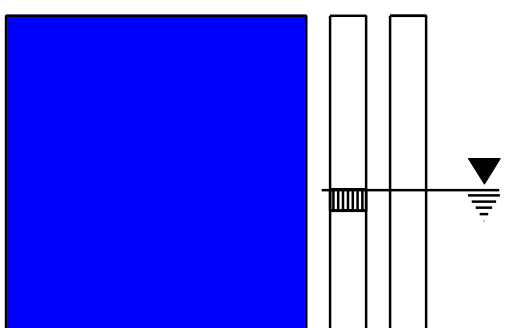

Tuff confining unit

Lava-flow aquifer

Tuff confining unit

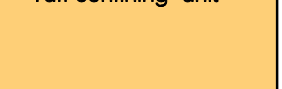

|.|. |. |

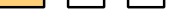

Confining unit Confining unit $\quad$ WU interval

Aquifer

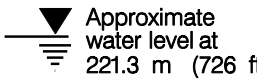

Figure B-2

Geology and Hydrogeology of Well Cluster ER-5-4 


\section{APPENDIX C}

Hydrostratigraphic Profiles through the Frenchman Flat Model Area 


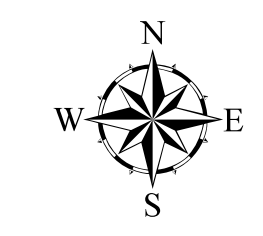

Hydrostratigraphic

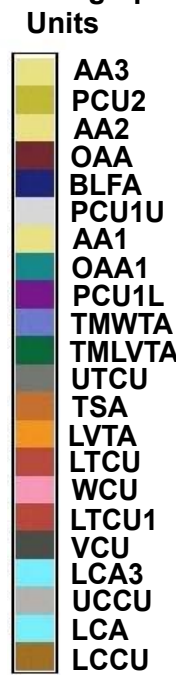

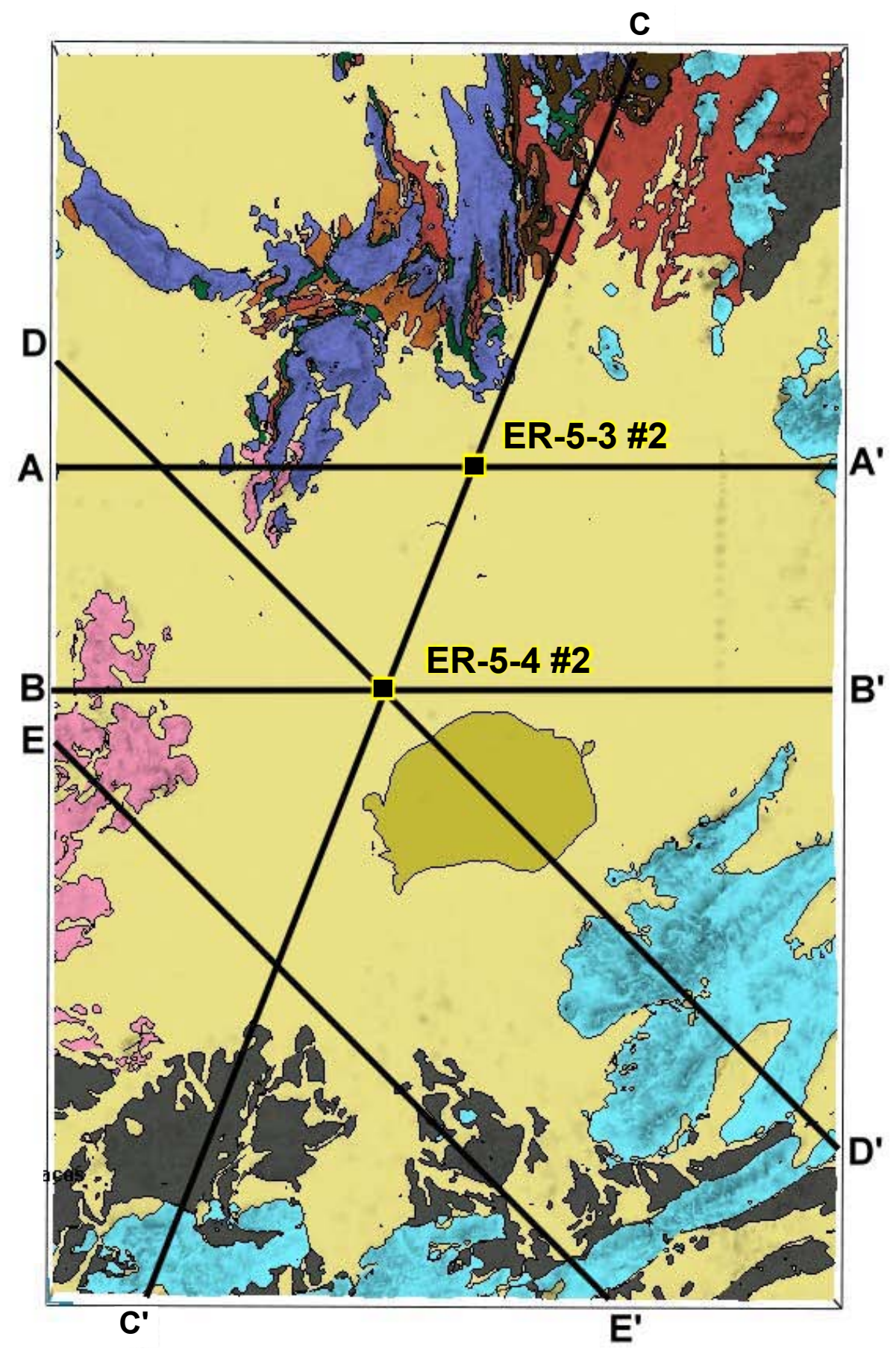

Figure C-1 Locations of Model Profiles from the Frenchman Flat Hydrostratigraphic Model 


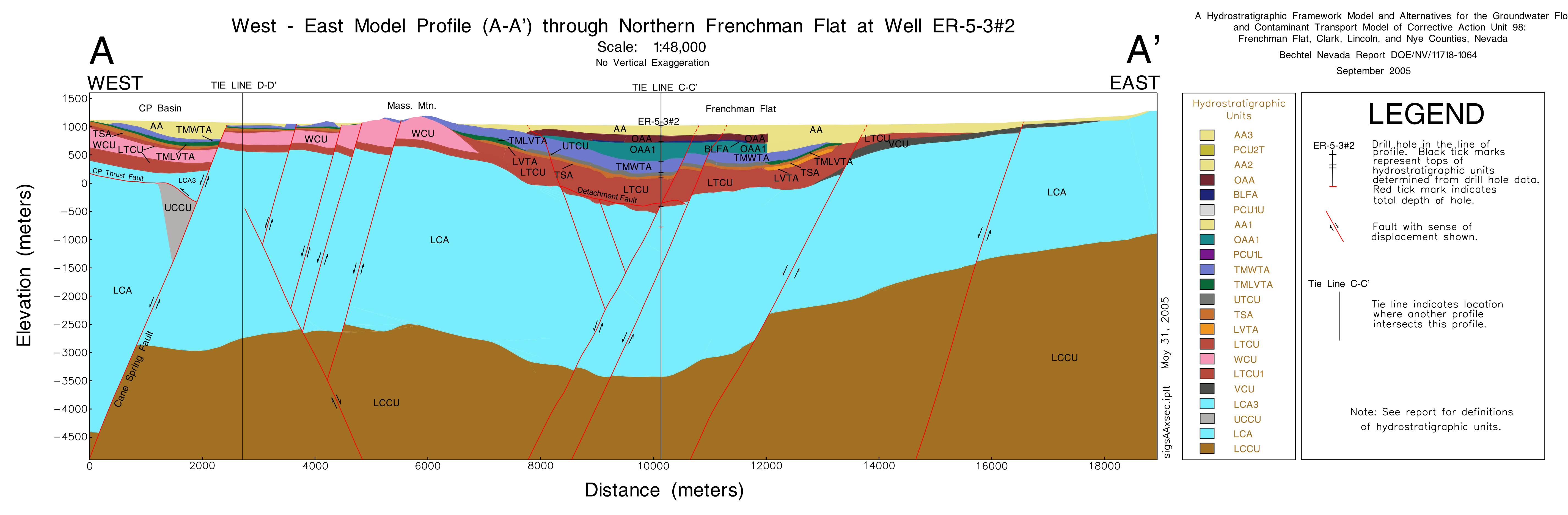




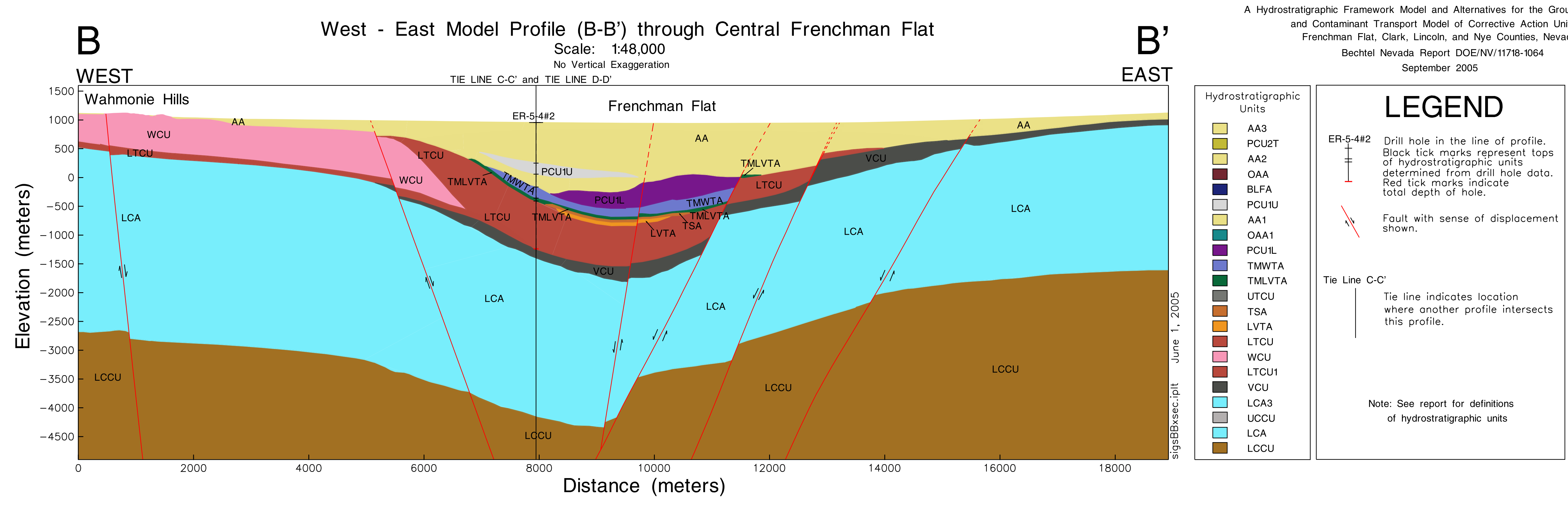




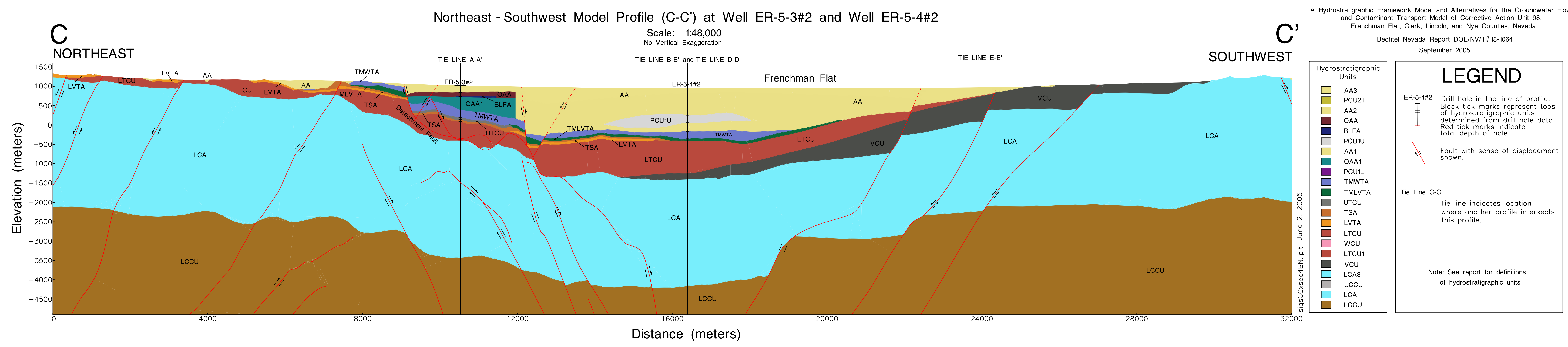




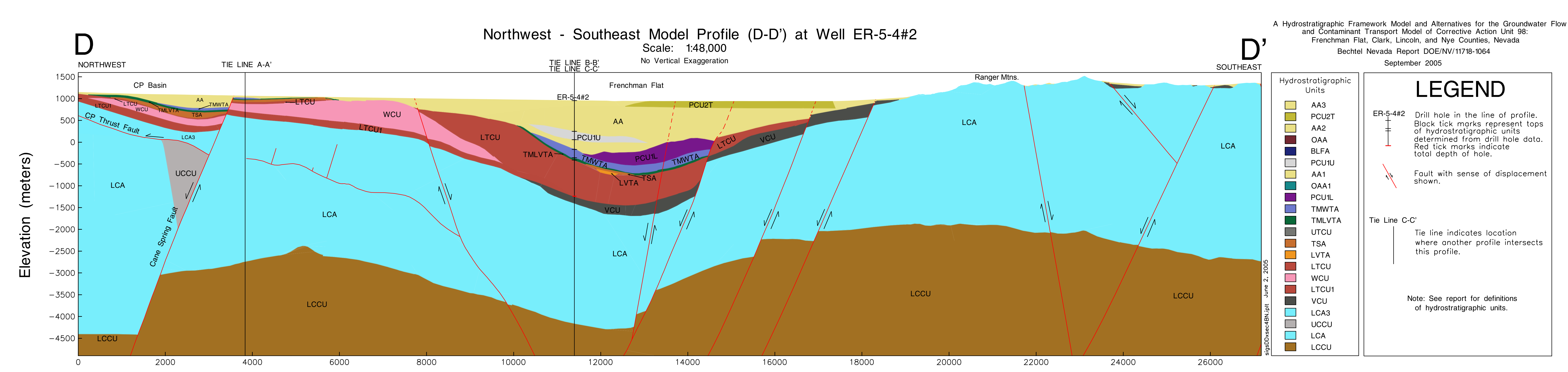




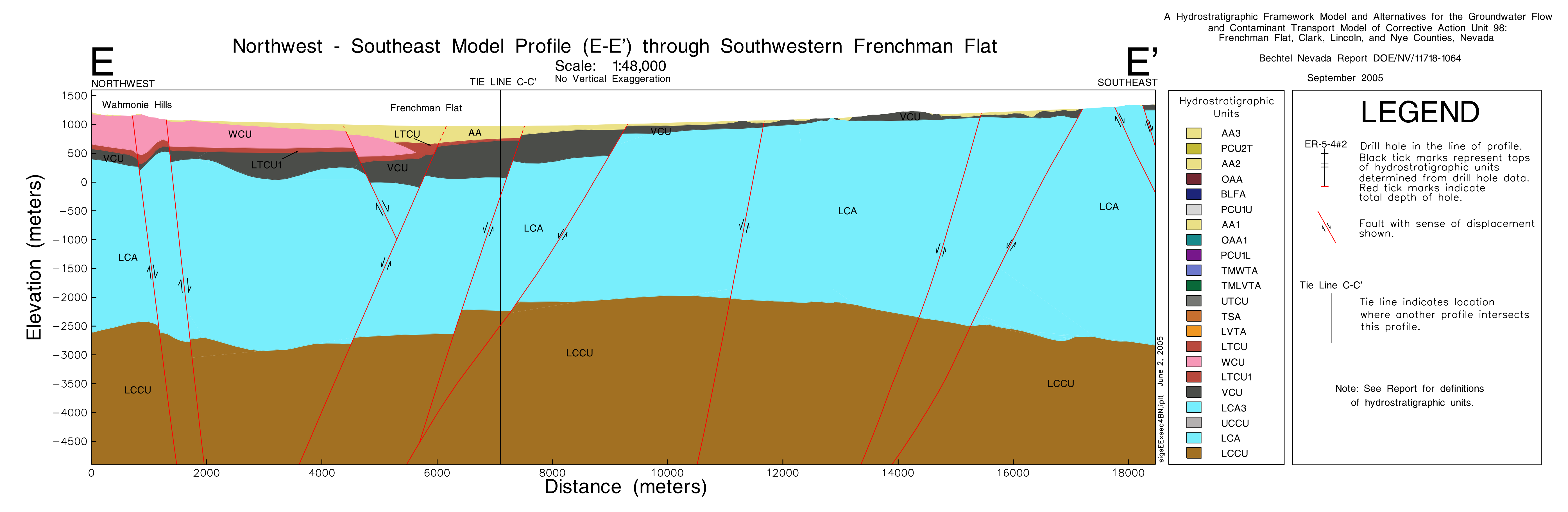




\section{APPENDIX D}

3-D Seismic Survey in Frenchman Flat 


\title{
Frenchman Flat 3-D Seismic Survey
}

\author{
by \\ Carl Schaftenaar, Great Basin Exploration Consultants, Inc. \\ Jerome B. Hansen, Great Basin Exploration Consultants, Inc. \\ Lance Prothro, Bechtel Nevada
}

September 2004 


\section{Table of Contents}

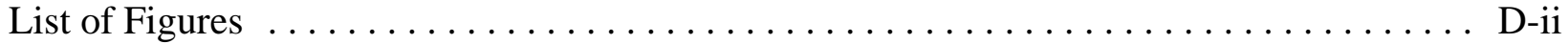

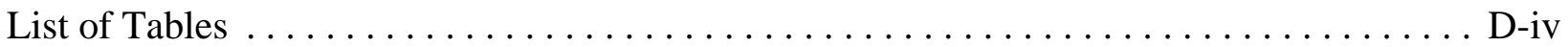

List of Acronyms and Abbreviations $\ldots \ldots \ldots \ldots \ldots \ldots \ldots \ldots \ldots \ldots \ldots \ldots \ldots \ldots \ldots \ldots \ldots$

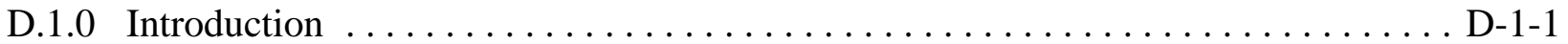

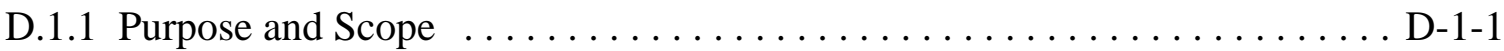

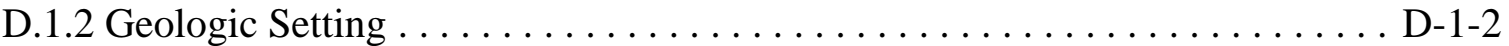

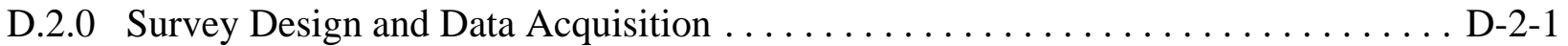

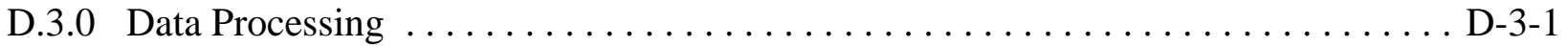

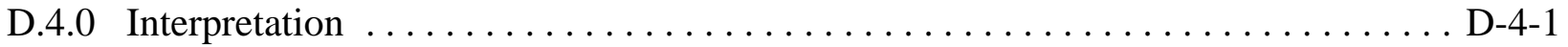

D.4.1 Data Utilized . . . . . . . . . . . . . . . . . . . . . . . . . . . . . . . D-4-1

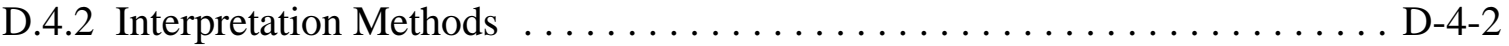

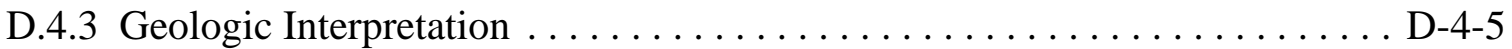

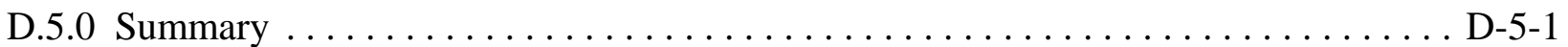

D.6.0 References ........................................ D-6-1 


\section{List of Figures}

\section{All figures are found at the end of each section.}

Number

D.1-1

D.1-2

D.1-3

D. $4-1$

D.4-2

D.4-3

D.4-4

D.4-5

D.4-6

D. $4-7$

D.4-8

D.4-9

D.4-10

D.4-11

D.4-12

D.4-13

D.4-14

D.4-15

D.4-16

D.4-17

D.4-18
Title

Satellite Image of the Frenchman Flat Area Showing Location of the 3-D Seismic Survey Area

Stratigraphic Column for Frenchman Flat

Simplified Geologic Map of the Frenchman Flat Vicinity Showing the General Structural Model of the Basin

Geologic Map of the Frenchman Flat 3-D Seismic Survey Area

Index Map of the Frenchman Flat 3-D Seismic Survey Area Showing Locations of Drill Holes and Seismic Profiles Referred to in this Report

Composite Synthetic Seismogram for Wells ER-5-3 and ER-5-3\#2

Composite Synthetic Seismogram for Wells ER-5-4 and ER-5-4\#2

Synthetic Seismogram for UE-11a

Synthetic Seismogram for UE-11b

Synthetic Seismogram for UE-5cWW

Synthetic Seismogram for UE-5i

Synthetic Seismogram for UE-5K

Estimated Time Values for Starting Depths of Logs Used to Construct TimeDepth Curves for the Frenchman Flat 3-D Seismic Survey

Time-Depth Curves Utilized for the Frenchman Flat 3-D Seismic Survey

Time-Structure Map for Base of Alluvium (BOA)

Time-Structure Map for Base of Welded Zone (BWZ)

Time-Structure Map for Top of Paleozoic Rocks (Pz)

Time-Depth Curves for Alluvium

Velocity Map from Surface to Base of Alluvium (BOA)

Structure Map of the Base of Alluvium (BOA)

Time-Depth Curves for Volcanic Rocks 


\section{List of Figures (continued)}

\section{All figures are found at the end of each section.}

Number

D.4-19 Velocity Map from the Base of Alluvium (BOA) to Base of Welded Zone (BWZ)

D.4-20

D.4-21

D.4-22

D.4-23

D.4-24

D.4-25

D.4-26
Title
Velocity Map from Base of Welded Zone (BWZ) to Top of Paleozoic Rocks (Pz)

Structure Map of the Top of Paleozoic Rocks (Pz)

Interpreted Seismic Profile along Inline 101, Looking North

Interpreted Seismic Profile along Crossline 55, Looking West

Interpreted Seismic Profile along Crossline 160, Looking West

Interpreted Seismic Profile along Inline 481, Looking North

D-iii 


\section{List of Tables}

Number

Title

Page

D.2-1 Acquisition Parameters for the Frenchman Flat 3-D Seismic Survey . . . . . D-2-2

D.3-1 Processing Steps Performed on the Frenchman Flat 3-D Seismic Data ... . D-3-2

D.4-1 Sources of Velocity Data for the Frenchman Flat 3-D Seismic Survey ... . D-4-3 


\section{List of Acronyms and Abbreviations}

$\begin{array}{ll}\text { 3-D } & \text { three-dimensional } \\ \text { BN } & \text { Bechtel Nevada } \\ \text { BOA } & \text { base of alluvium } \\ \text { BWZ } & \text { base of welded zone } \\ \mathrm{ft} & \text { feet } \\ \text { GBEC } & \text { Great Basin Exploration Consultants, Inc. } \\ \text { km } & \text { kilometer(s) } \\ \mathrm{m} & \text { meter(s) } \\ \mathrm{mi} & \text { mile(s) } \\ \mathrm{NNSA} / \mathrm{NSO} & \text { National Nuclear Security Administration, Nevada Site Office } \\ \text { NTS } & \text { Nevada Test Site } \\ \text { Pz } & \text { top of Paleozoic rocks } \\ \text { UGTA } & \text { Underground Test Area Project } \\ \text { Vector } & \text { Vector Seismic Data Processing, Inc. }\end{array}$


This page intentionally left blank.

D-vi 


\section{D.1.0 Introduction}

A 35.8 square-kilometer (13.8-square mile) three-dimensional (3-D) seismic reflection survey was conducted for the U.S. Department of Energy, National Nuclear Security Administration Nevada Site Office (NNSA/NSO) in support of the Nevada Environmental Restoration Project at the Nevada Test Site (NTS), Nye County, Nevada (Prothro, 2001). The seismic survey was conducted as part of the hydrogeologic investigation program for Frenchman Flat. This program is part of the NNSA/NSO Environmental Restoration Division's Underground Test Area (UGTA) project at the NTS. The goals of the UGTA project include evaluating the nature and extent of contamination in groundwater due to underground nuclear weapons testing, and establishing a long-term groundwater monitoring network. As part of the UGTA project, scientists are developing computer models to predict groundwater flow and contaminant migration within and near the NTS. To build and test these models, it is necessary to collect geologic, geophysical, and hydrologic data to help define groundwater migration pathways, migration rates, and quality.

The seismic survey area is located in the northern and central portions of Frenchman Flat and includes all the sites of underground nuclear weapons tests conducted in Frenchman Flat (Figure D.1-1). Project management and technical oversight were provided by Bechtel Nevada (BN). Data acquisition was performed by Subsurface Exploration Company. Vector Seismic Data Processing, Inc. processed the seismic data. Collection and processing of gravity data for static corrections were performed by Opfer Exploration, Inc. Great Basin Exploration Consultants, Inc. (GBEC) functioned as technical advisor to BN. Interpretation of the seismic data was performed by BN and GBEC.

\section{D.1.1 Purpose and Scope}

The goal of the Frenchman Flat 3-D seismic survey was to acquire subsurface geologic information to better constrain the distribution of hydrostratigraphic units and major structural features in the vicinity of underground nuclear test locations in Frenchman Flat. Specific objectives included:

- $\quad$ Determine the depth to the top of the Paleozoic-age rocks which form the regional aquifer

- $\quad$ Identify faults

- $\quad$ Determine the extent of the welded volcanic units that form the volcanic aquifers

- $\quad$ Map the base of the alluvial basin fill which forms the alluvial aquifer. 
The seismic data and interpretations allow for more accurate modeling of groundwater flow and radionuclide migration in the region, and a more realistic evaluation of potential "short-circuit" groundwater pathways from the higher basin aquifers where underground nuclear tests were conducted to the deeper regional aquifer.

\section{D.1.2 Geologic Setting}

Frenchman Flat is a hydrographically closed, Cenozoic-age basin formed in response to Basin and Range tectonism. Topographically, the basin is roughly oval-shaped, elongated in a northeast direction, and contains a playa lake in the southeast which marks the topographic low point of the basin (see Figure D.1-1).

Rocks exposed in the highlands around the margins of Frenchman Flat consist of Tertiary-age volcanic and tuffaceous sedimentary rocks that overlie complexly folded and faulted Paleozoicage sedimentary rocks (Hinrichs and McKay, 1965; Poole, 1965; Poole et al., 1965; Hinrichs, 1968; McKeown et al., 1976; Barnes et al., 1982). The volcanic rocks are mostly Miocene-age tuffs of generally rhyolitic composition erupted from large calderas located 40 kilometers (km) (25 miles [mi]) northwest of Frenchman Flat, and intermediate-composition tuffs, lavas, and debris flows from the Wahmonie volcanic center located adjacent to Frenchman Flat on the west. Tuffaceous sedimentary rocks appear to occur within a rather narrow, linear, northeast-trending depositional area that generally corresponds to the topographic axis of the basin (Prothro and Drellack, 1997). These rocks are exposed along the southern margin of the basin where they consist of a diverse assemblage of fluvial and lacustrine sandstone and mudrocks, freshwater limestone, conglomerate, and volcanic tuff. The tuffaceous sedimentary rocks appear to be partly coeval with the older volcanic rocks and thus likely interfinger with the volcanic rocks beneath Frenchman Flat. Paleozoic-age sedimentary rocks are exposed along the south and east sides of Frenchman Flat and consist mostly of carbonate rocks ranging in age from Cambrian to Mississippian.

Drilling and geophysical data from Frenchman Flat indicate that many of the rocks exposed along the margins of the basin are present beneath Frenchman Flat, and have been buried by thick aprons of alluvial debris shed from the exposed highlands during basin development. At its deepest point the basin is filled with approximately 1,500 meters (m) (5,000 feet [ft]) of Tertiary and Quaternary alluvium that overlies approximately 1,300 $\mathrm{m}(4,300 \mathrm{ft})$ of Tertiary volcanic and tuffaceous sedimentary rocks. Figure D.1-2 is a simplified stratigraphic column for the Frenchman Flat area.

The formation of Frenchman Flat is directly related to the northeastern termination of the Rock Valley strike-slip fault zone within an extensional imbricate fan (Figure D.1-3). The formation of this fan structure has resulted in a series of oblique-slip faults that flare out to the north and northwest from the Rock Valley fault zone in the southern portion of Frenchman Flat. These faults drop the basin down along the south, east, and north forming an east-tilted half-graben. The resulting basin, as illustrated on Bouguer gravity contours, is tear-drop shaped and elongated in the northeast-southwest direction. 


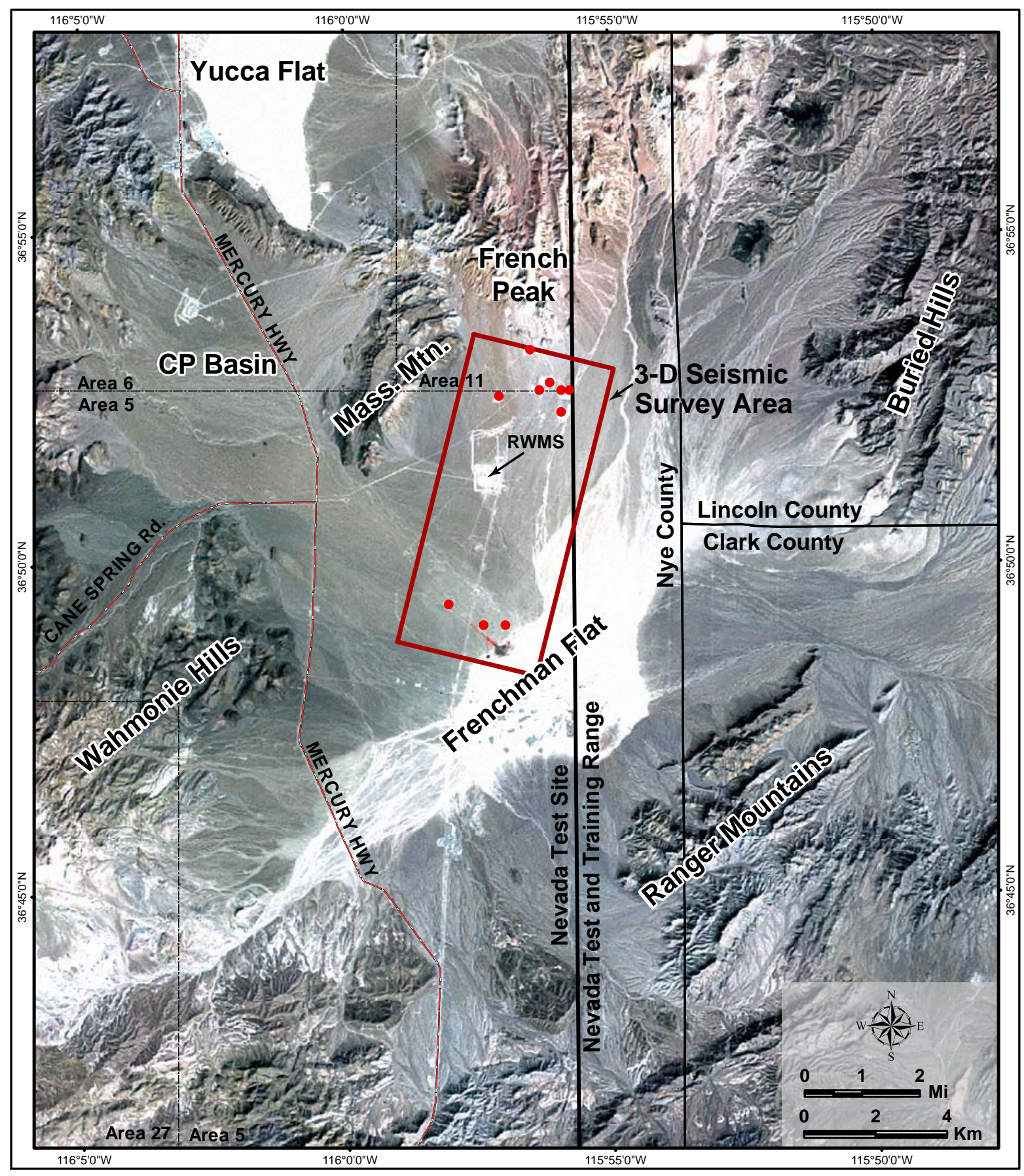

Figure D.1-1

Satellite Image of the Frenchman Flat Area Showing Location of the 3-D Seismic Survey Area

Red dots are locations of expended underground nuclear tests. 


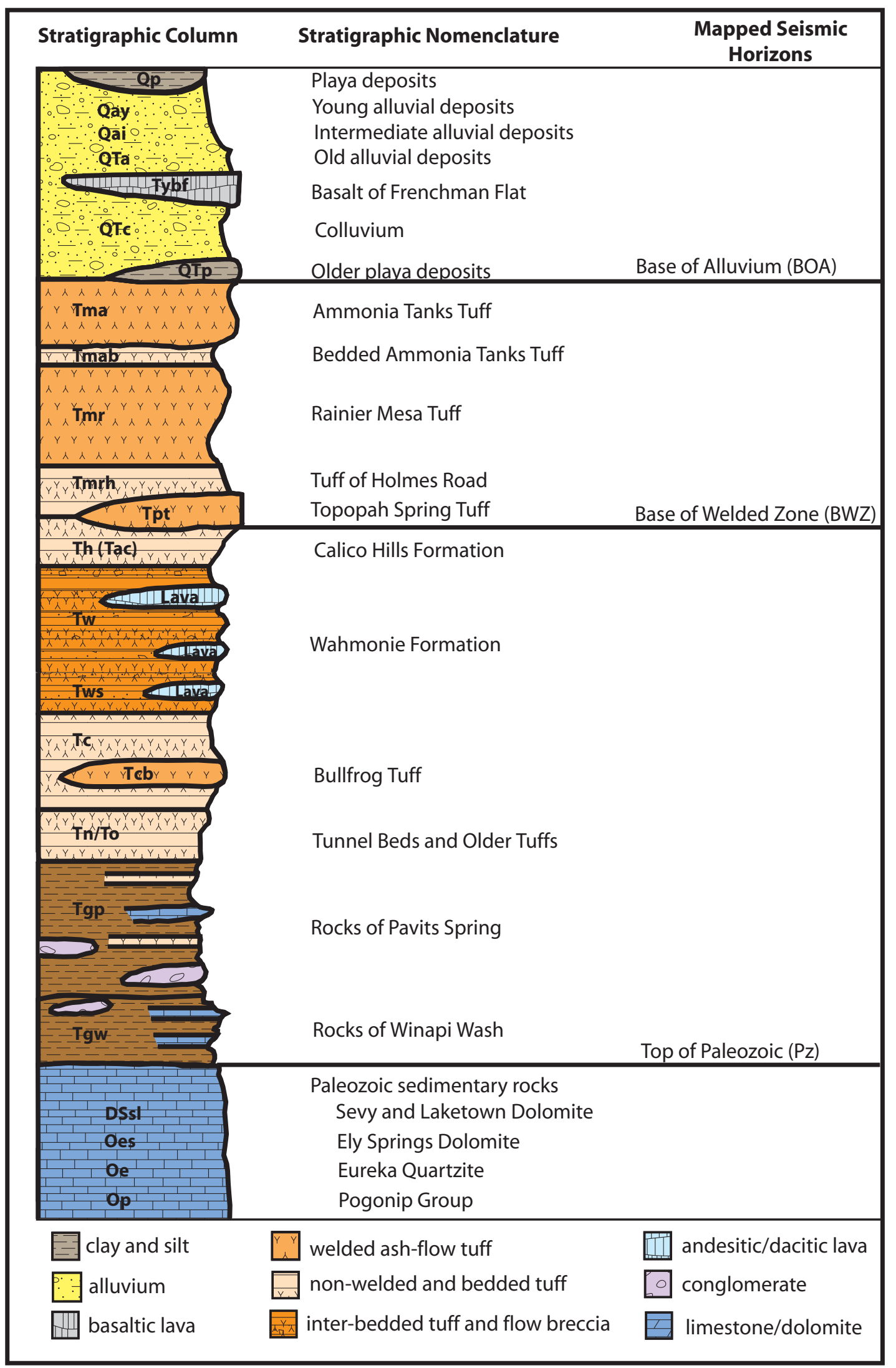

Figure D.1-2

Stratigraphic Column for Frenchman Flat 


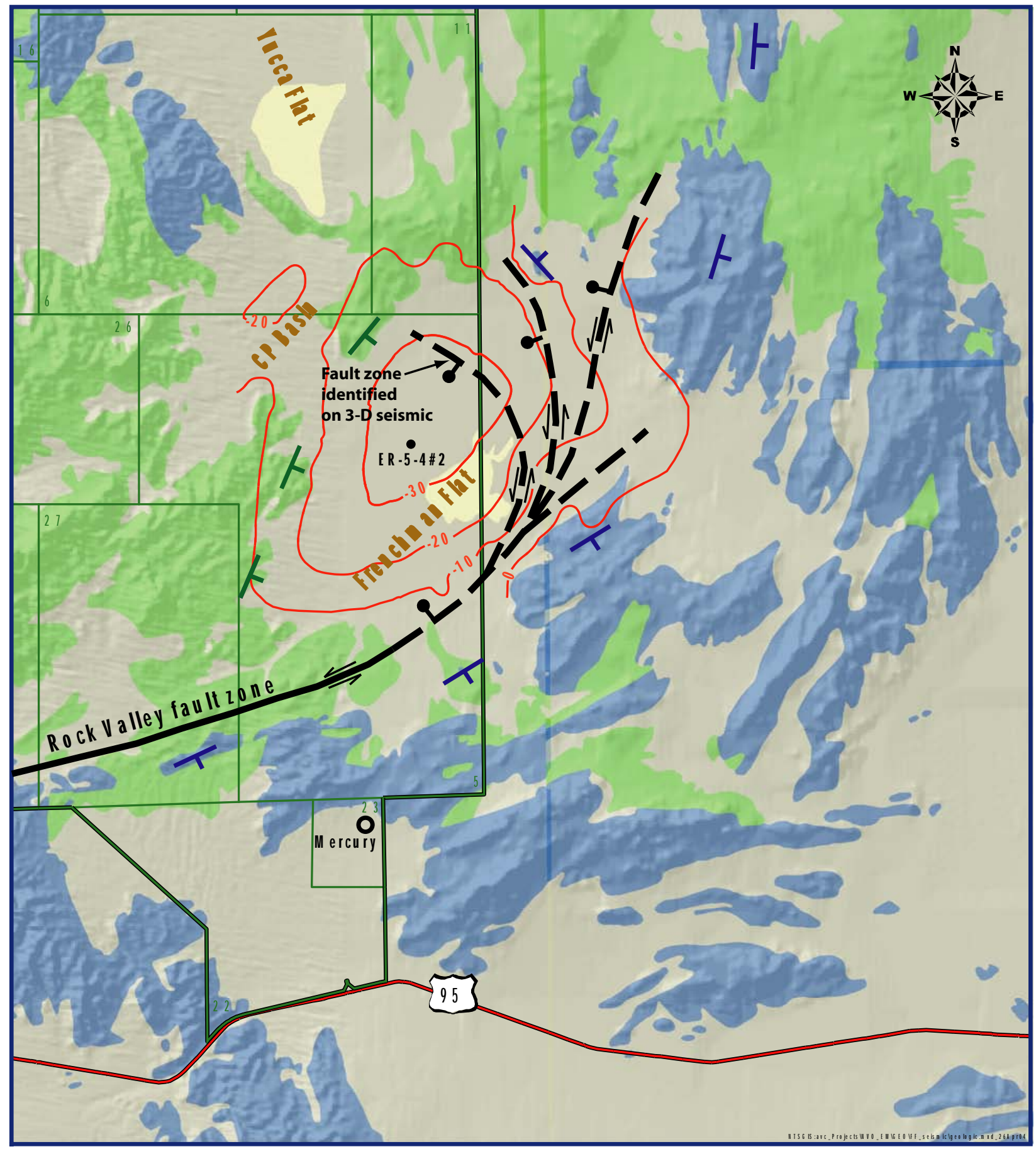

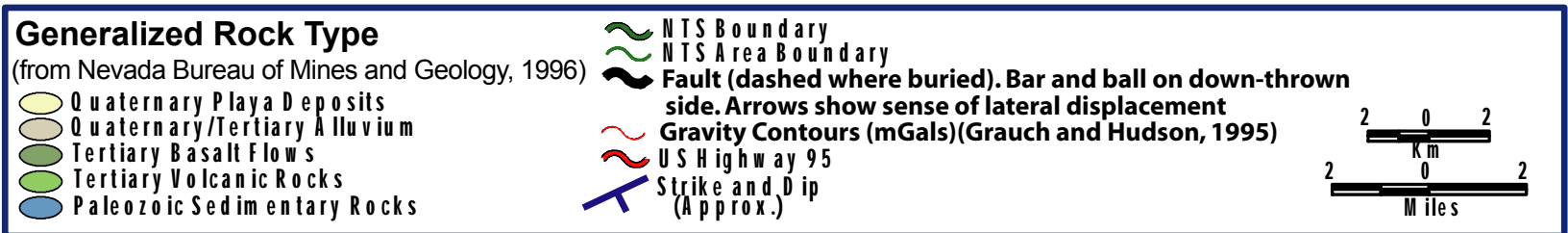

Figure D.1-3

Simplified Geologic Map of Frenchman Flat and Vicinity showing the General Structural Model of the Basin 


\section{D.2.0 Survey Design and Data Acquisition}

The Frenchman Flat 3-D seismic survey was designed to record seismic data over all underground nuclear test locations within the basin (see Figure D.1-1). This was accomplished within in a rectangular-shaped layout $8.9 \mathrm{~km}(5.5 \mathrm{mi})$ long and $4.0 \mathrm{~km}$ (2.5 mi) wide with the long axis oriented north-northeast. Target depths of the survey were from 300 to 3,660 m (1,000 to $12,000 \mathrm{ft}$ ) below ground surface (0.35 to 2.5 seconds). Table $2-1$ lists acquisition parameters. The original survey design called for an $18.3 \mathrm{~m} \mathrm{x} 18.3 \mathrm{~m}$ (60 ft x $60 \mathrm{ft}$ ) bin spacing.

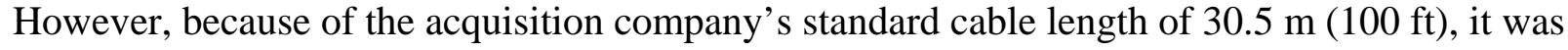

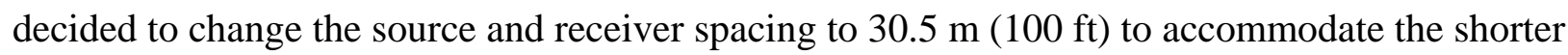
cable lengths. This produced a higher resolution $15.2 \mathrm{~m} \mathrm{x} 15.2 \mathrm{~m}$ (50 ft x $50 \mathrm{ft}$ ) bin design at no additional cost. Because the source and receiver lines had already been established and cleared for archeological and biological resources, line spacing was not changed, which resulted in a more randomly spaced data set.

Data acquisition was conducted from August to December, 2001. Access within the survey area was generally good; however, some areas were inaccessible due to subsidence craters, radiological surface contamination, and a radioactive waste management facility.

A high spatial frequency gravity survey was also conducted in conjunction with the seismic survey to provide gravity-derived static corrections to the seismic data. Gravity measurements were made at every third receiver and source point resulting in a total of 2,991 gravity measurements. 


\section{Table D.2-1}

\section{Acquisition Parameters for the Frenchman Flat 3-D Seismic Survey}

Survey area:

Target depths:

Target times:

Total number of receiver lines:

Receiver line spacing:

Receiver point interval:

Live channels per line:

Number of live receiver lines:

Total live channels:

Number of receiver points:

Number of geophones per receiver point:

Geophone array:

Source line spacing:

Source line orientation:

Source point interval:

Number of source points:

Maximum inline offset:

Maximum crossline offset

Maximum offset (diagonal)

Source type:

Source array:

Number of sweeps per source point:

Sweep length:

Listen time:

Frequency range:

Sample interval:

Correlated record length:

Approximate number of traces recorded:

Bin size:

Number of bins:

Maximum fold:
35.8 square kilometers ( 13.8 square miles)

$300-3,660 \mathrm{~m}(1,000-12,000 \mathrm{ft})$

$0.35-2.5$ seconds

28

$329.2 \mathrm{~m}(1,080 \mathrm{ft})$

$30.5 \mathrm{~m}(100 \mathrm{ft})$

132

12

1,584

3,723

6

3.0-m (10-foot) circle centered on flag

$402.3 \mathrm{~m}(1,320 \mathrm{ft})$ (284.4 $\mathrm{m}$ [933 ft] normal to source lines) 45 degrees to receiver lines

$30.5 \mathrm{~m}$ (100 ft) (43.1 m [141.4 ft] along source lines) 2,930

$2,176.3 \mathrm{~m}(7,140 \mathrm{ft})$

$1,959.9 \mathrm{~m}(6,430 \mathrm{ft})$

$2,928.8 \mathrm{~m}(9,609 \mathrm{ft})$

Vibroseis $(30,000$ pounds peak force)

4 vibrators in a box pattern

8

12 seconds

4 seconds

10 - 80 hertz

2 milliseconds

4 seconds

$4,500,000$

$15.2 \mathrm{~m} \times 15.2 \mathrm{~m}(50 \mathrm{ft} \times 50 \mathrm{ft})$

153,855

30 


\section{D.3.0 Data Processing}

Vector Seismic Data Processing, Inc. (Vector) performed the data processing to produce the stacked and migrated data volumes using ProMAX ${ }^{\circledR}$ by Landmark Graphics Corporation and Vector proprietary software. The basic processing steps used on the Frenchman Flat data are summarized in Table 3-1. The processing steps that proved particularly important with regards to the Frenchman Flat data included velocity analysis and NMO correction, determination of mutes, and post-stack noise filtering such as FXY deconvolution and Tau-p filtering.

Because of the great thickness of low velocity material in the valley fill alluvium, stacking velocities were low and increased very slowly with time/depth. Therefore, very small incremental changes in stacking velocities were required to analyze and determine the appropriate stacking velocities.

Much of the coherent reflection signal on the resulting stack came from the mid- to far-offset range. The near offsets were dominated by source generated noise, while the longest offsets were contaminated by reverberating first arrival energy. Because of the strong first arrival energy, the top mute was picked very carefully to remove first arrival energy but leave far offset reflections in the stack.

After stacking, a strong pattern of linear noise was noticed on the data. This noise pattern originated from stacking of source generated noise in certain directions and attenuation of source generated noise in other directions. This resulted in source generated noise stacking to form an "acquisition footprint” on the stacked data. Vector devised a form of their proprietary Tau-p filter in order to successfully filter the linear noise from the data as a post-stack process. 
Table D.3-1

Processing steps performed on the Frenchman Flat 3-D seismic data

\author{
Reformat from SEG-Y \\ Geometry Application \\ Trace Edits \\ True Amplitude Correction \\ Shot Balance \\ Deconvolution \\ Spectral Whitening \\ Datum Statics \\ Velocity Analysis \\ Autostatics \\ NMO Correction \\ Trace Balance \\ Top Mute \\ Shift to Final datum \\ Stack \\ Trace Balance \\ FXY Deconvolution \\ Migration \\ Additional Processing \\ Gravity-Derived Static Corrections (pre-stack) \\ Tau-p Filter (post-stack)
}

D-3-2 


\section{D.4.0 Interpretation}

\section{D.4.1 Data Utilized}

Seismic data in Nevada tend to be difficult to interpret due to the discontinuous nature of the continental sediments which can produce discontinuous and incoherent seismic reflections. In addition, thick deposits of relatively low-velocity alluvium that fill basins like Frenchman Flat can seriously attenuate the seismic signal, particularly the higher frequencies, thus reducing the strength of the seismic signal reflecting from deeper horizons. The top of the Paleozoic rocks can be particularly difficult to image because of its greater depth and the uneven nature of this eroded surface. Very few coherent reflections are observed within the Paleozoic rocks in the Frenchman Flat 3-D data or on two-dimensional seismic data from Yucca Flat located just north of Frenchman Flat. This is likely due to the weak signal at these depths, the lack of acoustic contrasts in this section typically dominated by carbonate rocks, and complex structure.

In spite of the difficulties described above, the seismic data set from Frenchman Flat, although somewhat noisy overall, is adequate for interpretation. In places, such as at the top of the Paleozoic rocks in the northeast corner of the survey area, the quality of the data is very good.

Five processed seismic data sets from the Frenchman Flat 3-D survey were available for interpretation, including the final unmigrated stack, migration before FXY filtering, migration after FXY filtering, migration after Tau-p filtering, migration after Tau-p filtering, and gravity statics. The migration after Tau-p filtering was judged to be the most coherent of these data volumes, and the interpretation was made on this volume. The other data volumes were utilized to clarify interpretations and evaluate seismic travel times.

Amplitude was the primary seismic attribute utilized during the interpretation process. However, other attributes such as frequency, reflection strength, average energy, and phase were also utilized in various instances to help clarify and refine interpretations.

Other types of geologic and geophysical data were also utilized and integrated into the seismic interpretation. These included the following:

- $\quad$ Surface geologic maps (Poole, 1965; Hinrichs and McKay, 1965; Slate et. al., 1999).

- Geophysical data and interpretations from gravity, aeromagnetic, and surface magnetic investigations (Slate et. al., 1999; Grauch and Hudson, 1995; Carr et. al., 1975).

- Information from 35 drill holes, including lithologic descriptions, formation tops, well logs, and check shot surveys. 


\section{D.4.2 Interpretation Methods}

Interpretation of the seismic data was performed using the seismic interpretation software application $2 \mathrm{~d} / 3 \mathrm{dPAK}{ }^{\circledast}$ by Seismic Micro-Technology, Inc. The basic workflow for interpreting the Frenchman Flat seismic data consisted of a four step process as described below.

\section{Step 1 - Development of an integrated geologic - geophysical base map.}

A variety of spatial data were imported into $2 \mathrm{~d} / 3 \mathrm{~d} \mathrm{PAK}^{\circledR}$ to produce an integrated geologic and geophysical base map. Each data set could be turned on or off (i.e., displayed or hidden) on the base map as desired during interpretation of the seismic data. A digital version of the Slate et al. (1999) geologic map was imported to provide lateral outcrop control for interpretation (Figure D.4.1). Additional strike and dip information from geologic quadrangle maps (Poole, 1965; Hinrichs and McKay, 1965) were digitized and also incorporated into the base map. Other data included aeromagnetic contours (Grauch and Hudson, 1995), limits of buried basalt flows as defined by surface magnetics (Carr et al., 1975), geophysically inferred structures from Slate et al. (1999), and Bouguer gravity contours (Grauch and Hudson, 1995).

\section{Step 2 - Integration of geologic, well log, and velocity data from area drill holes into the 3-D seismic volume.}

Time-depth curves and synthetic seismograms were developed from density and sonic logs and from check shot surveys to tie the well data with the seismic data, and subsequently to identify seismic reflections based on the formation tops. The locations of the wells are shown on the index map of the seismic survey, Figure D.4-2.

Velocity information is available for ten wells within, and immediately adjacent to, the Frenchman Flat 3-D Survey (Table D.4-1, Figure D.4-2). The velocity data are from various sources including check shot surveys, velocity logs and sonic logs, or estimated from density logs.

Synthetic seismograms for nine of the wells were created and time-depth curves for the logged portion of all ten of the holes were calculated. Because the upper portions of drill holes ER-5-3\#2 and ER-5-4\#2 were not logged, the ER-5-3 and ER-5-3\#2 logs were combined to represent the borehole at the ER-5-3\#2, and the ER-5-4 and ER-5-4\#2 logs were combined to represent the borehole at the ER-5-4\#2 . The synthetic seismograms were computed using a 5-10-25-30 hertz, zero-phase wavelet to visually approximate the bandwidth of the seismic data. The synthetic seismograms are shown in Figures D.4-3 to D.4-9. 
Table D.4-1

Sources of Velocity Data for the Frenchman Flat 3-D Seismic Survey

\section{Sources of Velocity Data}

\begin{tabular}{|c|c|c|c|c|c|c|c|c|}
\hline \multirow[b]{2}{*}{ Well } & \multicolumn{3}{|c|}{ State Plane Coordinates } & \multicolumn{3}{|c|}{ Source of Velocity Data } & & \\
\hline & $X(f t)$ & $\mathrm{Y}(\mathrm{ft})$ & $Z(f t)$ & $\begin{array}{l}\text { Sonic or } \\
\text { Velocity Log } \\
\text { Depth (ft) }\end{array}$ & $\begin{array}{c}\text { Check } \\
\text { Shot } \\
\text { Depth (ft) }\end{array}$ & $\begin{array}{l}\text { Density } \\
\text { Log } \\
\text { Depth (ft) }\end{array}$ & Synthetic & \\
\hline$\overline{E R-5-3}$ & 713138.4 & 773579.4 & 3335 & $1229-2555.5$ & & & $\bar{Y}$ & \\
\hline ER-5-3\#2 & 713038.1 & 773587.6 & 3335 & $2555.75-5233$ & & & Y & \\
\hline ER-5-4 & 705819.9 & 755751.3 & 3127 & $2430-3583.25$ & & $120-2430$ & Y & * \\
\hline ER-5-4\#2 & 705819.6 & 755651.2 & 3127 & $3090-6937$ & & & Y & \\
\hline UE-11a & 708280.0 & 777130.0 & 3547 & & $0-1385$ & & Y & \\
\hline UE-11b & 712300.0 & 778800.0 & 3586 & $287-1252$ & & & Y & \\
\hline UE-5cWW & 700997.0 & 760133.0 & 3216 & $110-2650$ & & & Y & ** \\
\hline UE-5i & 709282.0 & 775216.0 & 3427 & $290-2110$ & & & Y & \\
\hline UE-5k & 715247.0 & 773094.0 & 3349 & $880-1720$ & & & $\mathrm{Y}$ & \\
\hline UE-5n & 706415.0 & 754460.0 & 3112 & & $0-985$ & & $\mathrm{~N}$ & \\
\hline
\end{tabular}

All units in feet, all depths are from the surface

* Velocity estimated above 2430 feet from VEL $=500 * \mathrm{DEN}^{\wedge} 4$ (Modified Gardner Equation)

** Interpolated 1620 to 1680 
Complete time-depth curves (from the surface to total depth of the well) require that an estimate be made for the time value at the depth of the start of the log. This time estimate was made by visually correlating the synthetic seismogram with the migrated 3-D seismic data in wells where characteristic seismic reflections are present. When appropriate reflections were lacking, the estimate were made by using realistic velocities for the near-surface non-logged part of the well. Figure D.4-10 shows the time-depth plot for the "start of the log" values. This figure illustrates that reasonable velocities have been estimated for the upper portion of the boreholes, and that only a small variation in near surface velocity is present. Solid lines are plotted for the two wells where check shot data are available. Figure D.4-11 shows the complete time-depth curves for all wells with velocity data. Also shown on Figure D.4-11 are the time-depth curves used for wells within the survey area that have no velocity information available. These curves are designated as "North Wells" and "South Wells" and closely approximate the time-depth curves from other wells in those areas.

The final time-depth curves were calculated by adding the time from the surface to the seismic datum. The seismic datum is $1,066.8 \mathrm{~m}(3,500 \mathrm{ft})$ elevation and the datum velocity is 1,524.0 meters per second (5,000 feet per second).

\section{Step 3 - Picking of horizons and faults.}

Three seismic horizons were picked (i.e., seismically mapped throughout the survey) using $2 \mathrm{~d} / 3 \mathrm{dPAK}{ }^{\circledR}$. These horizons from highest to lowest are 1 ) the base of alluvium (BOA), 2) base of the welded tuff zone (BWZ), and 3) and the top of Paleozoic rocks (Pz).

The horizons were picked on a grid of inlines and crosslines at every tenth line (i.e., every $152.4 \mathrm{~m}[500 \mathrm{ft}])$ within the survey area and tied at each grid intersection point. Near the locations of faults, horizon picking was done on a grid of every one or two lines (i.e., 15.2 or $30.5 \mathrm{~m}$ [50 to $100 \mathrm{ft}$ ]) to more tightly constrain the horizons. The horizons were then interpolated over the survey area. Faults were picked where the reflections from the welded zone or Paleozoic top were broken, and were picked on a grid of two or five lines. Figures D.412, D.4-13 and D.4-14 are the time horizon contour maps for BOA, BWZ, and Pz.

\section{Step 4 - Conversion of seismic horizons from time to depth.}

A 3-layer velocity model was created to convert the seismic time horizons to depth. Depths were adjusted to a sea-level datum to yield structure contour maps.

The velocity within the alluvium is primarily a function of seismic time or depth, and is mainly due to an increase in compaction of the alluvial sediments with depth. Four "best-fit" $4^{\text {th }}$ order polynomial equations (Figure D.4-15) were used to describe the relationship between the depth of the base of the alluvium and the two-way seismic time below the surface. Fit 1 was used to represent the time-depth curve at the UE-5cWW and PW-3 wells. Fit 2 was used to represent time-depth curve at the ER-5-4, ER-5-4\#2, U-11b, UE-11b and U-11c\#1 wells. Fit 3 was used to represent the time-depth curve at the UE-11a and UE-5i wells. Fit 4 was used to represent the 
time-depth curve at the ER-5-3, ER-5-3\#2 and UE-5k wells. These relationships were interpolated and extrapolated throughout the 3-D survey area in order to calculate an interval velocity for the alluvium at every seismic trace within the survey. The grid of interval velocities, which is depicted as a contour map in Figure D.4-16, was used to convert the BOA horizon to depth by multiplying by the seismic time from the surface at each trace. These depths were adjusted to a sea-level datum to yield the structure contour map for the BOA (Figure D.4-17).

A similar time-depth relationship exists for the volcanic section penetrated by the wells (Figure D.4-18), and two best-fit $4^{\text {th }}$ order polynomial equations were used to describe this relationship. Fit 1 was used to represent the time-depth curve at the ER-5-3, ER-5-3\#2 and UE-5k wells. Fit 2 was used to represent the time-depth curve at the ER-5-4, ER-5-4\#2, PW-3, UE-11a, U-11b, UE-11b, UE-5cWW, and UE-5i wells. It was determined that a significant variation did not exist between the average velocities in the more welded upper part of the volcanic section and the lower non-welded tuff in the study area, and thus, these equations (Figure D.4-18) were used to calculate interval velocities for both BOA to BWZ and BWZ to Pz. Interval velocities for BOA to BWZ (Figure D.4-19) were calculated from the polynomial equations for the volcanic section. This velocity map was multiplied by the interval time and the resulting thickness was added to that determined for the base of alluvium to produce a depth map on the base of the welded zone. This was adjusted to a sea-level datum to produce the BWZ structure contour map (Figure D.4-20). The same procedure was used between the base of the welded zone and top of the Paleozoic to delineate the interval velocity between $\mathrm{BWZ}$ and $\mathrm{Pz}$ (Figure D.4-21), and to produce the structure contour map for Pz (Figure D.4-22).

\section{D.4.3 Geologic Interpretation}

The most uniform set of reflections in the survey comes from welded tuffs above the BWZ (Figure D.4-23). The BWZ was picked at the bottom trough of this series of very prominent reflections. These reflections are uniformly strong and identifiable over most of the survey area, except at the margins where fold buildup (i.e., number of recorded seismic traces) is low. Based on correlation with synthetic seismograms for Wells ER-5-3\#2 and ER-5-4\#2, the reflections are identified as the Ammonia Tanks, Rainier Mesa, and Topopah Spring Tuffs. These units compose a sequence of welded ash-flow tuff deposits that typically occur at the top of the volcanic section in the vicinity of Frenchman Flat. Below the welded tuffs is a zone of poor reflectivity and low energy that corresponds to a sequence of poorly welded, zeolitic tuffs and tuffaceous sedimentary rocks that extend down to the Pz.

The $\mathrm{Pz}$ is a strong, prominent peak in the data volume in the northern part of the survey, but is less evident in the southern part of the survey (Figure D.4-24, Figure D.4-25, Figure D.4-26). The only hole within the survey area to penetrate completely through the alluvium and volcanic sections and encounter the top of the Pz is Well ER-5-3\#2. At Well ER-5-3\#2, the Pz consists of dolomite, and reflection quality is excellent in the vicinity of the hole (see Figure D.4-26). 
The BOA is not a consistent reflection in the survey. However, in many places a prominent and conspicuous angular unconformity is observed in the seismic data at the BOA (Figure D.4-23). In addition, a number of holes in the survey area that have velocity data have penetrated this unconformity, and these data can be utilized to constrain and tie the location of the unconformity on the seismic data throughout the survey.

In the southern portion of the survey area two zones of low reflectivity occur within the alluvium section (see Figure D.4-23). The upper of these two zones is penetrated by Well ER-5-4\#2 where it corresponds to fine-grained sand, silt, and clay that is interpreted to represent an earlier period of playa deposition. The lower zone is not penetrated by any drill holes, and is defined strictly on a similar seismic character to the upper zone. This lower zone is also interpreted to represent playa deposits.

Several of the deeper reflections below the $\mathrm{Pz}$ in the southern portion of the survey area are suspected of being multiples. Multiples are reflections resulting from sound waves that make an extra return trip, either between reflectors (i.e., peg-leg multiple) or down from the surface and back again (i.e., surface multiple). On crossline 55 (Figure D.4-24) near line 200 for example, the sets of reflections at 0.95 seconds and 1.32 seconds are clearly primary reflections and not surface multiples, because the time dip on the lower set is not twice the time dip on the upper set. There is less certainty about the sets of reflections between 1.8 and 2.2 seconds, however. Although the time dip is not double that of the upper or lower sets, it is possible that the set at 1.8 seconds could be a peg-leg multiple generated from the sets at 0.95 and 1.32 seconds.

Based on the seismic data, the overall shape of Frenchman Flat within the survey area is best described as a syncline in the southern two thirds of the survey area which rises up to a structural platform on the north. The axis of the syncline is oriented about north 15 degrees east (see Figure D.4-17). The northwestern flank of the syncline has a dip of $29^{\circ}-33^{\circ}$ to the southeast, as measured at the BWZ in the southwestern part of the survey area (see Figure D.4-20), and confirmed with dipmeter analysis of the borehole image log from Well ER-5-4\#2. The deepest part of the basin occurs in the southeast part of the survey, where the base of alluvium is approximately $-556 \mathrm{~m}(-1,825 \mathrm{ft})$ in elevation or 1,501 $\mathrm{m}(4,925 \mathrm{ft})$ deep, and the $\mathrm{Pz}$ is estimated to be at $-1,829 \mathrm{~m}(-6,000 \mathrm{ft})$ elevation or 2,789 m (9,150 ft) deep (see Figure D.4-22). At Well ER-5-4\#2 in the southwestern portion of the survey, and up dip from the deepest portion of the basin based on seismic, the base of the alluvium was encountered at a depth of 1,120.4 m $(3,676 \mathrm{ft})$. The well failed to reach the Pz and bottomed in Tertiary volcanic rocks at a depth of 2,133.6 m (7,000 ft).

The northern third of the survey area is best characterized as consisting of a faulted structural platform, particularly at the Pz. A series of north-northeast-striking, down-to-the-west faults through the central portion of the platform result in the platform being structurally higher on the west (Figure D.4-26). The depth to Pz ranges from approximately 1,158.2 m (3,800 ft) on the 
west side of Figure D.4-26, to greater than 1,645.9 m (5,400 ft) east of Well ER-5-3\#2. At Well ER-5-3\#2 the Pz was encountered at the depth of 1,425.9 m (4,678 ft).

A large northwest-striking structural zone separates the northern structural platform from the deeper Frenchman Flat basin proper to the south. The structural zone displaces the $\mathrm{Pz}$ as much as $609.6 \mathrm{~m}(2,000 \mathrm{ft})$ in a series of down-to-the-southwest normal faults, and is itself offset by a north-northeast-striking fault that seems to be a continuation of the faults that offset the structural platform to the north (see Figures D.4-22 and D.4-24). Offset along this fault appears to be oblique, with both down-to-the-west normal and right-lateral strike-slip movement. The fault continues southward into the southeastern portion of the survey area where it appears to significantly decrease in the amount of normal offset.

The disparity in depth to the volcanic rocks between wells UE-11b and UE-11g ext 1 (338.6 vertical meters [1,111 ft] and 1,036.3 horizontal meters [3,400 ft] at BOA) and the shallow dip of the reflections of the volcanic rocks here, indicate that a high-angle normal fault is present between these two wells (see Figure D.4-17). The magnitude of throw along this fault is a maximum of about $548.6 \mathrm{~m}(1,800 \mathrm{ft})$, and displacement likely dies to the west into the corner between the Massachusetts Mountains and French Peak. However, the fault does not appear to cause a large offset at the Pz reflections. This implies that a low-angle zone of detachment exists between the BWZ and the Pz, and that much of the displacement seen in the welded zone of the upper volcanic section is dissipated in this zone of detachment (Figure D.4-25).

Additional evidence for the presence of a high-angle fault that is rooted in a low-angle detachment zone below the northern portion of the seismic area, is observed in seismic reflections from the volcanic section. Seismic reflections from the volcanic rocks show an anticlinal feature just south of hole UE-11g ext 1 (Figure D.4-25). However, the anticlinal form does not extend downward to the top of the Paleozoic rocks, which are clearly expressed on the seismic data in this area. This type of large-scale disharmonic folding is common along highly listric normal faults where such folds are referred to as rollover anticlines (Twiss and Moores, 1992). Rollover anticlines form in the hanging wall of concave upward listric normal faults as a result of the hanging wall strata tilting downward and deforming to maintain contact with the footwall of the fault. 
This Page Intentionally Left Blank.

D-4-8 


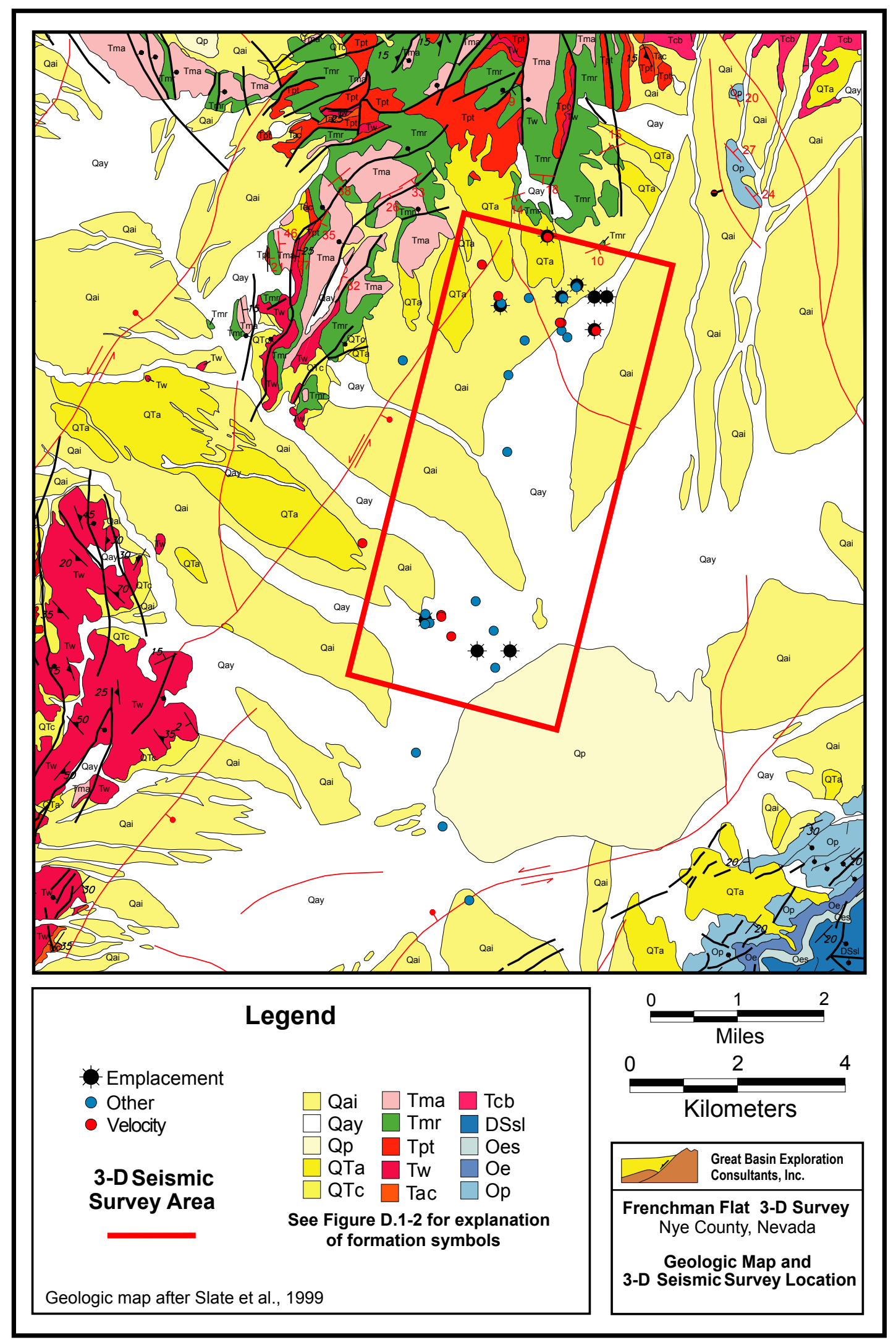

Figure D.4-1

Geologic Map of the Frenchman Flat 3-D Seismic Survey Area 


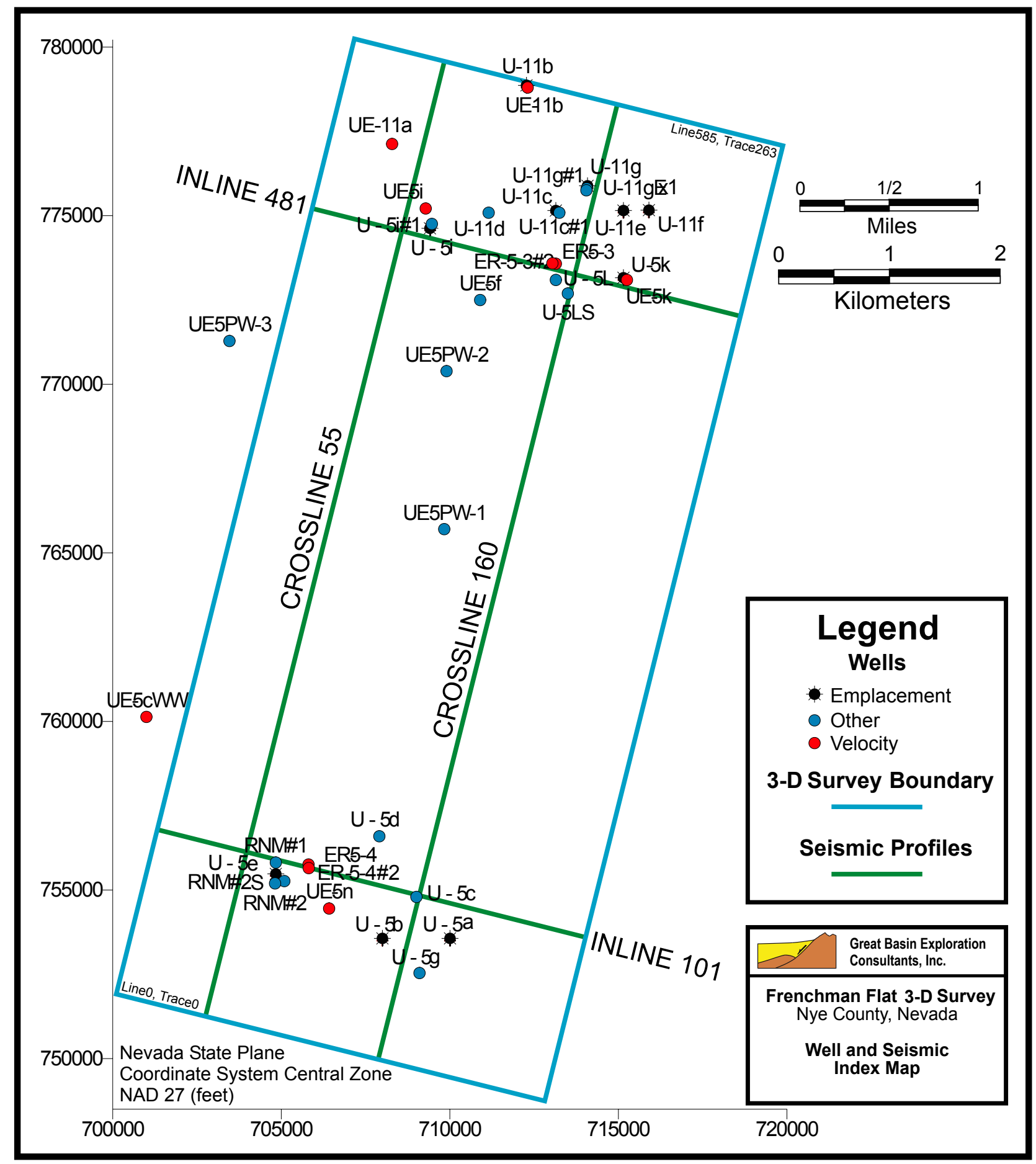

Figure D.4-2

Index Map of the Frenchman Flat 3-D Seismic Survey Area Showing Locations of Drill Holes and Seismic Profiles Referred to in this Report 
ER-5-3 (1040.5-2555.5) w/ ER-5-3\#2 (2555.75-5233.0)

edited at misinterpolations ER5-3(1040.5-2555.5) w/ ER5-3\#2(2555.75-5233.0)

$\mathrm{KB}=3335 \mathrm{ft} \quad \mathrm{GL}=3335 \mathrm{ft} \quad$ Datum $=3335 \mathrm{ft} \quad$ Datum Velocity $=5438 \mathrm{ft} / \mathrm{sec}$

Time scale $=5$ inches $/$ second $\quad$ Traces $/$ inch $=10 \quad$ AGC length $=$ None

Sample rate $=2 \mathrm{msec}$ Acoustic impedance from sonic log

Date plotted: 09-07-2004 Measurement Units: Feet

Depth (ft) RC Normal Reverse Velocity (kft/s)

0.4

5

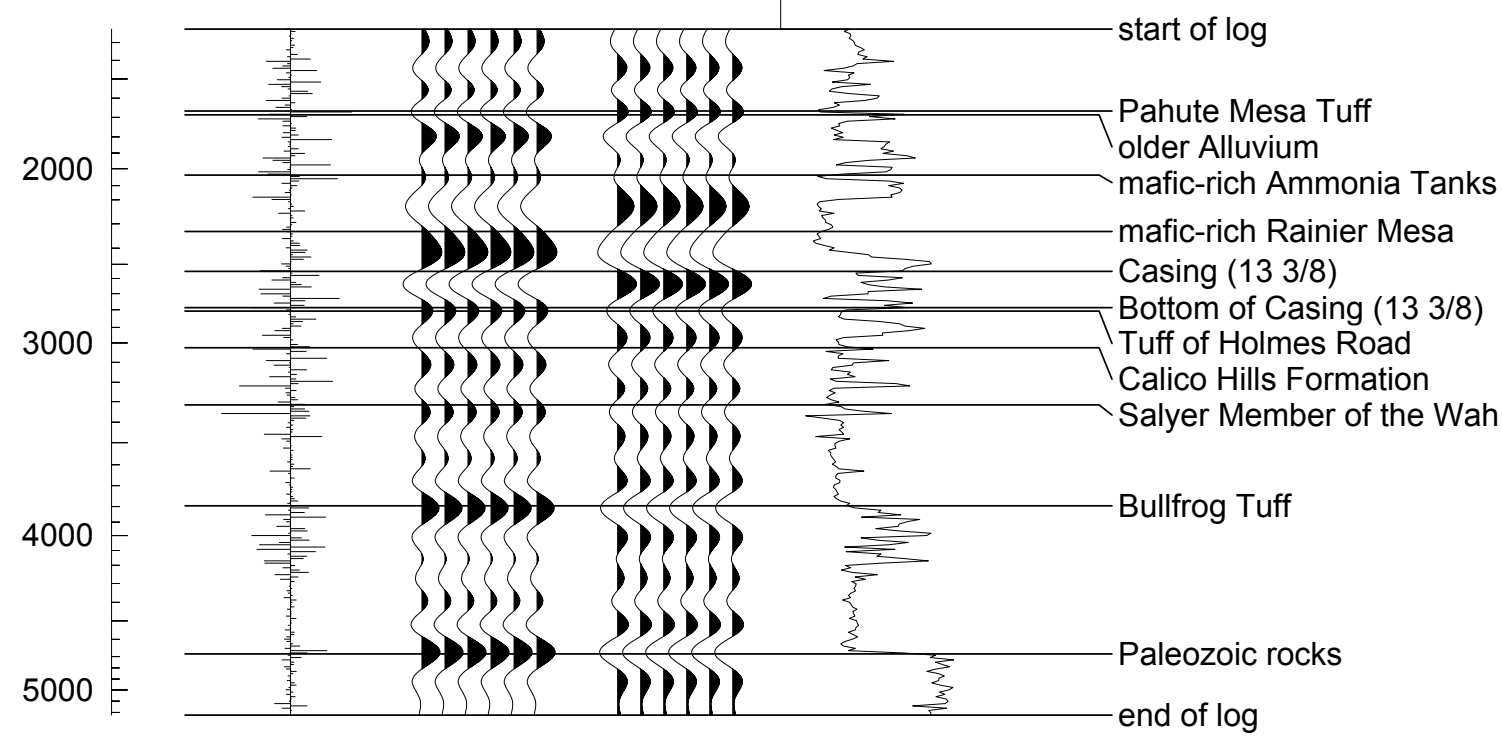

\begin{tabular}{|c|c|c|c|c|c|c|c|}
\hline start of log & 1229 & 2106 & 0.452 & 5438 & & & \\
\cline { 7 - 8 } Pahute Mesa Tuff & 1665 & 1670 & 0.523 & 6364 & 0.071 & 12234 \\
\hline older Alluvium & 1682 & 1653 & 0.527 & 6389 & 17 & 0.003 & 10469 \\
\hline mafic-rich Ammonia Tanks & 2042 & 1293 & 0.579 & 7054 & 360 & 0.052 & 13734 \\
\hline mafic-rich Rainier Mesa & 2334 & 1001 & 0.628 & 7434 & 292 & 0.049 & 11929 \\
\hline Casing (13 3/8) & 2556 & 780 & 0.663 & 7714 & 222 & 0.035 & 12789 \\
\hline Bottom of Casing (13 3/8) & 2784 & 551 & 0.694 & 8023 & 229 & 0.031 & 14518 \\
\hline Tuff of Holmes Road & 2807 & 528 & 0.697 & 8055 & 23 & 0.003 & 15678 \\
\hline Calico Hills Formation & 3024 & 311 & 0.729 & 8297 & 217 & 0.032 & 13565 \\
\hline Salyer Member of the Wah & 3315 & 20 & 0.778 & 8517 & 291 & 0.049 & 11764 \\
\hline Bullfrog Tuff & 3796 & -461 & 0.866 & 8765 & 481 & 0.088 & 10967 \\
\hline Paleozoic rocks & 4678 & -1343 & 0.995 & 9404 & 882 & 0.129 & 13697 \\
\hline end of log & 5223 & -1888 & 1.048 & 9967 & 545 & 0.053 & 20537 \\
\hline
\end{tabular}

Wavelet

5-10-25-30 Hz

Phase $=0$ degrees

Length $=0.200 \mathrm{Sec}$

QuickSyn ( 1996-2004 by GeoTools

Figure D.4-3

Composite Synthetic Seismogram for Wells ER-5-3 and ER-5-3\#2 
ER-5-4 composited with ER-5-4\#2

Composite Sonic below 2430 - Density(Gardner) above

$\mathrm{KB}=3127 \mathrm{ft} \quad \mathrm{GL}=3127 \mathrm{ft} \quad$ Datum $=3127 \mathrm{ft} \quad$ Datum Velocity $=2264 \mathrm{ft} / \mathrm{sec}$

Time scale $=5$ inches $/$ second $\quad$ Traces $/$ inch $=10 \quad$ AGC length $=$ None

Sample rate $=2 \mathrm{msec}$ Acoustic impedance from sonic log

Date plotted: 09-07-2004 Measurement Units: Feet

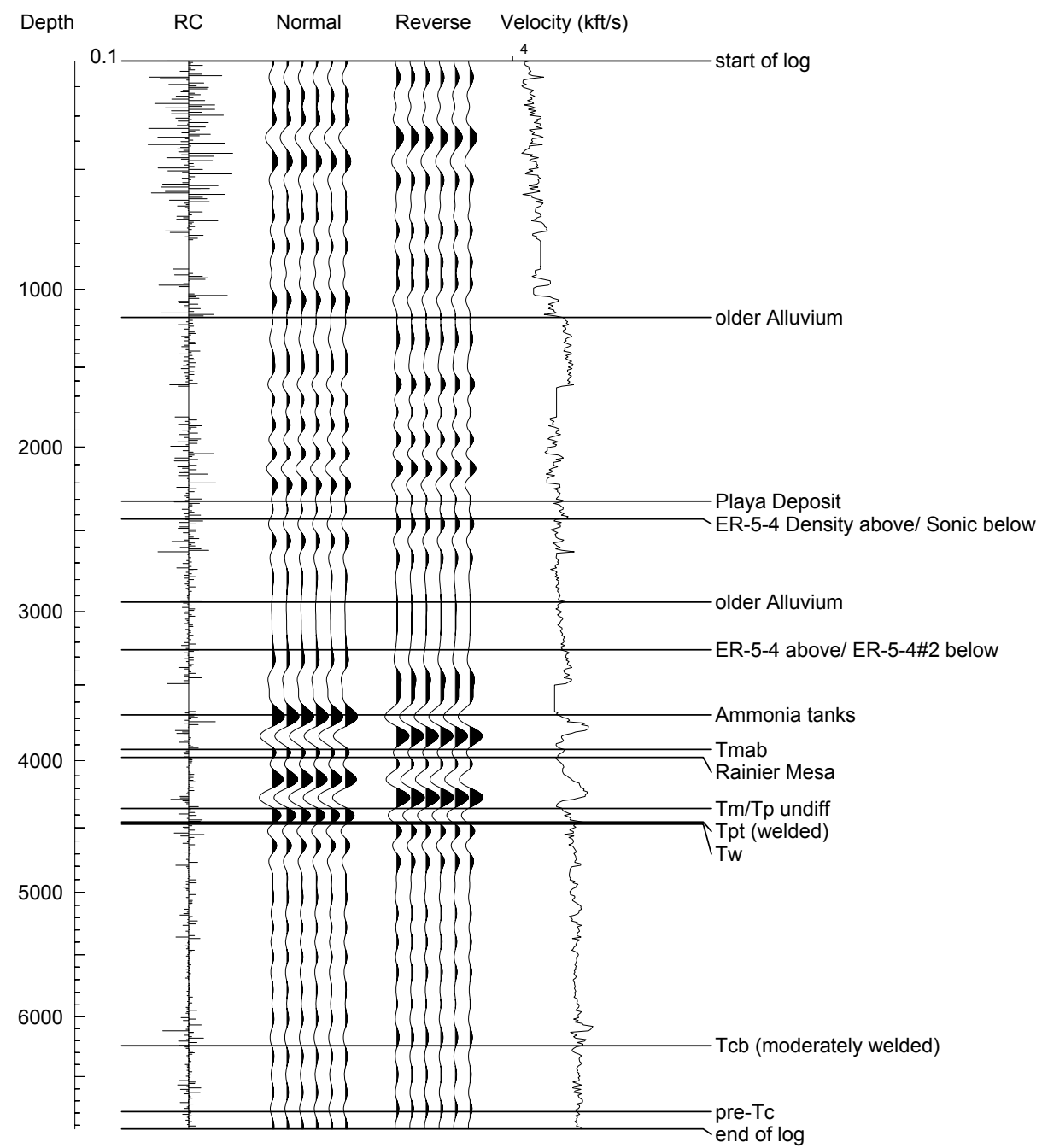

\begin{tabular}{|c|c|c|c|c|c|c|c|}
\hline start of log & 120 & 3007 & 0.106 & 2264 & & & \\
\hline older Alluvium & 1144 & 1983 & 0.456 & 5018 & 1024 & 0.350 & 5852 \\
\hline Playa Deposit & 2312 & 815 & 0.707 & 6541 & 1168 & 0.251 & 9309 \\
\hline ER5-4 Density above/ Sonic below & 2430 & 697 & 0.731 & 6644 & 118 & 0.025 & 9631 \\
\hline older Alluvium & 2940 & 187 & 0.845 & 6961 & 510 & 0.113 & 9006 \\
\hline ER5-4 above/ ER5-4\#2 below & 3250 & -123 & 0.910 & 7144 & 310 & 0.065 & 9514 \\
\hline Ammonia tanks & 3676 & -549 & 0.999 & 7361 & 426 & 0.089 & 9579 \\
\hline Tmab & 3928 & -801 & 1.046 & 7512 & 252 & 0.047 & 10719 \\
\hline Rainier Mesa & 3980 & -853 & 1.057 & 7533 & 52 & 0.011 & 9580 \\
\hline Tm/Tp undiff & 4356 & -1229 & 1.127 & 7734 & 376 & 0.070 & 10772 \\
\hline Tpt (welded) & 4452 & -1325 & 1.145 & 7777 & 96 & 0.018 & 10446 \\
\hline Tw & 4472 & -1345 & 1.148 & 7791 & 20 & 0.003 & 12977 \\
\hline Tcb (moderately welded) & 6246 & -3119 & 1.450 & 8613 & 1774 & 0.302 & 11731 \\
\hline pre-Tc & 6790 & -3663 & 1.540 & 8816 & 544 & 0.090 & 12081 \\
\hline end of log & 6931 & -3804 & 1.564 & 8863 & 141 & 0.024 & 11953 \\
\hline
\end{tabular}

Wavelet

5-10-25-30 Hz

Phase $=0$ degrees Length $=0.200 \mathrm{Sec}$

QuickSyn ๑ $1996-2004$ by GeoTools

Figure D.4-4

Composite Synthetic Seismogram for Wells ER-5-4 and ER-5-4\#2 


\section{UE-11a}

Synthetic from Check Shot

$\mathrm{KB}=3547 \mathrm{ft} \quad \mathrm{GL}=3547 \mathrm{ft} \quad$ Datum $=3547 \mathrm{ft} \quad$ Datum Velocity $=5000 \mathrm{ft} / \mathrm{sec}$

Time scale $=5$ inches $/$ second $\quad$ Traces/inch $=10 \quad$ AGC length $=$ None

Sample rate $=2 \mathrm{msec}$ Acoustic impedance from sonic log

Date plotted: 09-07-2004 Measurement Units: Feet

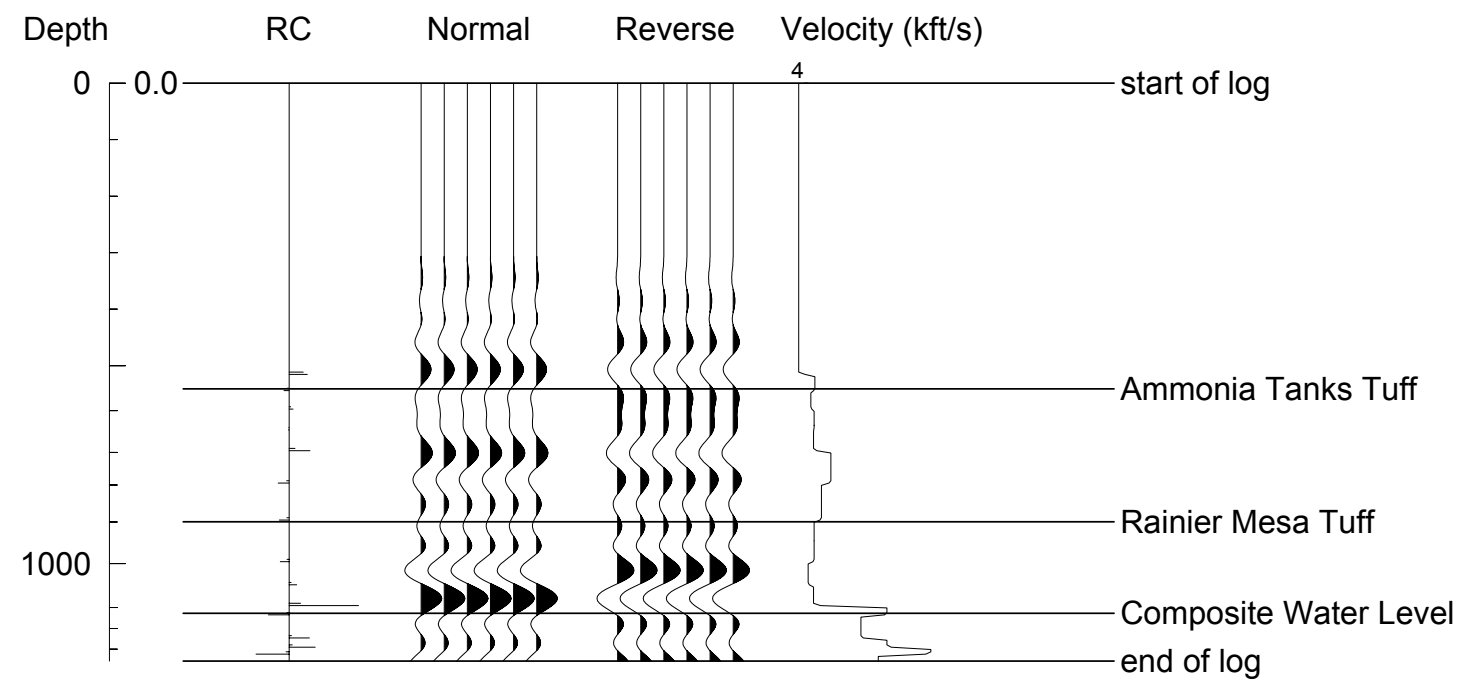

\begin{tabular}{|c|c|c|c|c|r|r|c|}
\hline start of log & 0 & 3547 & 0.000 & ----- & 550 & 0.265 & 4158 \\
\hline Ammonia Tanks Tuff & 550 & 2997 & 0.265 & 4158 & 350 & 0.115 & 6083 \\
\hline Rainier Mesa Tuff & 900 & 2647 & 0.380 & 4741 & 231 & 0.079 & 5839 \\
\hline Composite Water Level & 1131 & 2416 & 0.459 & 4930 & 243 & 0.041 & 11809 \\
\hline end of log & 1374 & 2173 & 0.500 & 5498 & 243 & &
\end{tabular}

Wavelet

5-10-25-30 Hz

Phase $=0$ degrees

Length $=0.200 \mathrm{Sec}$

QuickSyn @ 1996-2004 by GeoTools

Figure D.4-5 


\section{UE-11b}

synthetic from velocity log dt2

$\mathrm{KB}=3586 \mathrm{ft} \quad \mathrm{GL}=3586 \mathrm{ft} \quad$ Datum $=3586 \mathrm{ft} \quad$ Datum Velocity $=4159 \mathrm{ft} / \mathrm{sec}$

Time scale $=5$ inches $/$ second $\quad$ Traces $/$ inch $=10 \quad$ AGC length $=$ None

Sample rate $=2 \mathrm{msec}$ Acoustic impedance from sonic log

Date plotted: 09-07-2004 Measurement Units: Feet

Depth RC Normal Reverse Velocity (kft/s)

0.1

4

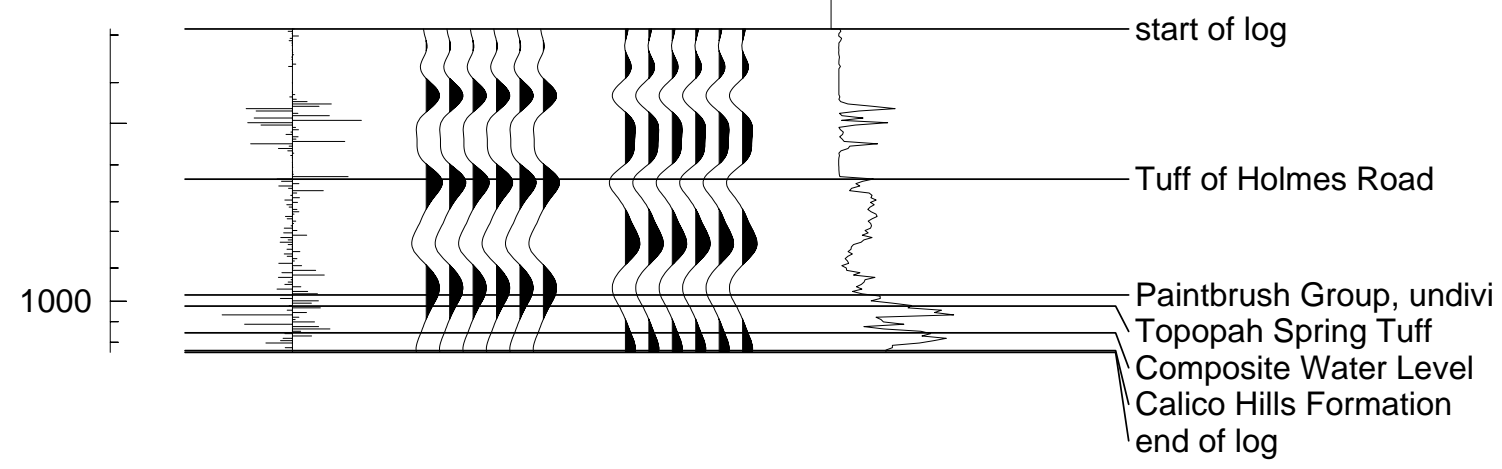

\begin{tabular}{|c|c|c|c|c|c|c|c|}
\hline start of log & 287 & 3299 & 0.138 & 4159 & & & \\
& Tuff of Holmes Road & 630 & 2956 & 0.266 & 4734 & 0.128 & 5352 \\
\hline Paintbrush Group, undivi & 978 & 2608 & 0.365 & 5358 & 348 & 0.099 & 7038 \\
\hline Topopah Spring Tuff & 1020 & 2566 & 0.375 & 5446 & 42 & 0.009 & 8848 \\
\hline Composite Water Level & 1146 & 2440 & 0.397 & 5768 & 126 & 0.023 & 11060 \\
\hline Calico Hills Formation & 1240 & 2346 & 0.413 & 6011 & 94 & 0.015 & 12360 \\
\hline end of log & 1247 & 2339 & 0.414 & 6023 & & 0.001 & 9310 \\
\hline
\end{tabular}

Wavelet 5-10-25-30 Hz Phase $=0$ degrees Length $=0.200 \mathrm{Sec}$

QuickSyn (C) $1996-2004$ by GeoTools

Figure D.4-6 Synthetic Seismogram for UE-11b 


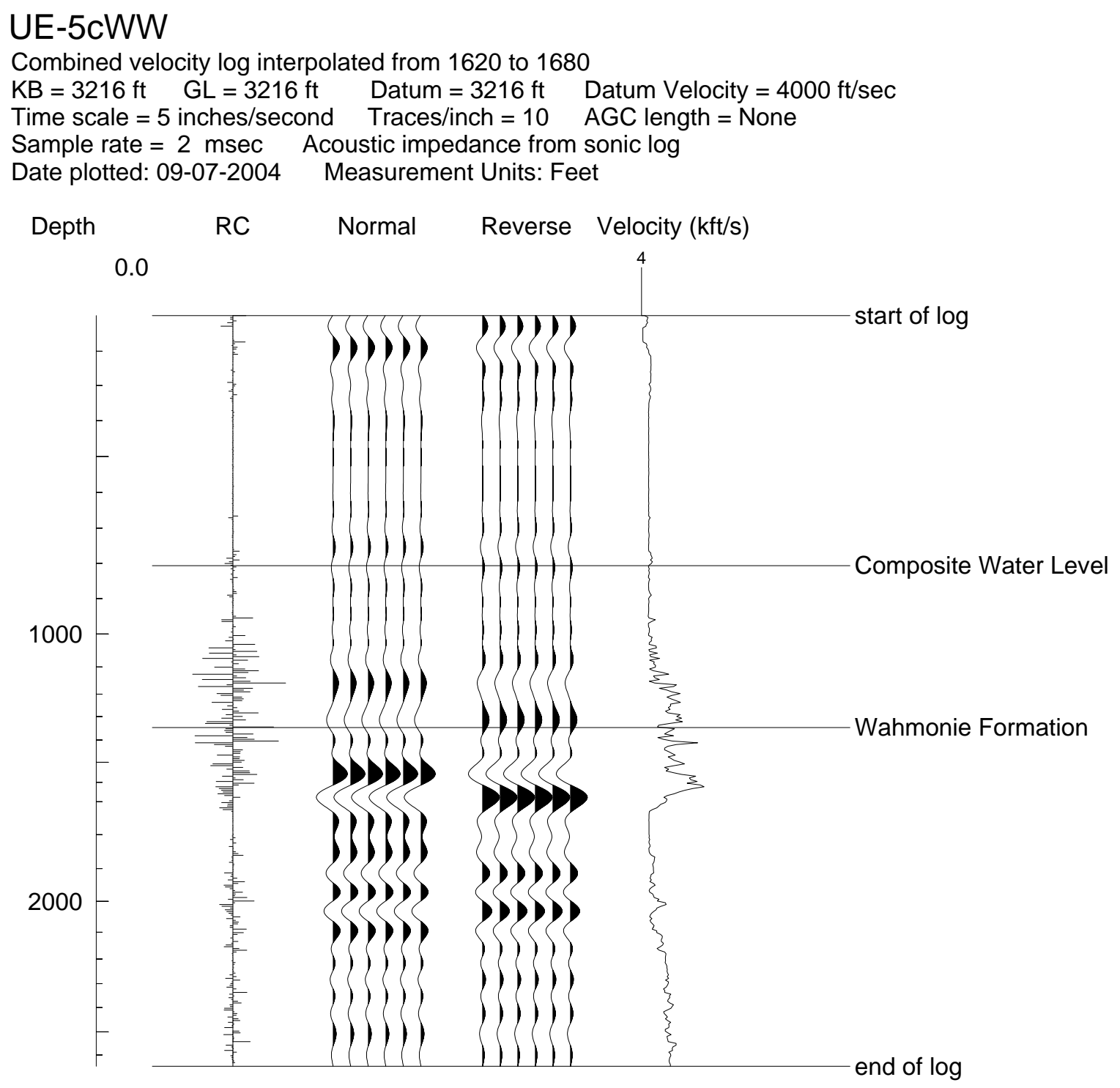

end of log

\begin{tabular}{|c|c|c|c|c|c|c|c|}
\hline start of log & 110 & 3106 & 0.055 & 4000 & & & \\
\hline Composite Water Level & 807 & 2409 & 0.340 & 4754 & 69 & 0.2 & 4900 \\
\hline Wahmonie Formation & 1350 & 1866 & 0.524 & 5154 & 543 & 0.184 & 5890 \\
\hline end of $\log$ & 2649 & 567 & 0.909 & 5828 & 1299 & 0.385 & 6745 \\
\hline
\end{tabular}

Wavelet

5-10-25-30 Hz

Phase $=0$ degrees

Length $=0.200 \mathrm{Sec}$

QuickSyn @ 1996-2004 by GeoTools

Figure D.4-7

Synthetic Seismogram for UE-5cWW 


\section{UE-5i}

Synthetic from velocity log

$\mathrm{KB}=3427 \mathrm{ft} \quad \mathrm{GL}=3427 \mathrm{ft} \quad$ Datum $=3427 \mathrm{ft} \quad$ Datum Velocity $=4143 \mathrm{ft} / \mathrm{sec}$

Time scale $=5$ inches $/$ second $\quad$ Traces $/$ inch $=10 \quad$ AGC length $=$ None

Sample rate $=2 \mathrm{msec}$ Acoustic impedance from sonic log

Date plotted: 09-07-2004 Measurement Units: Feet

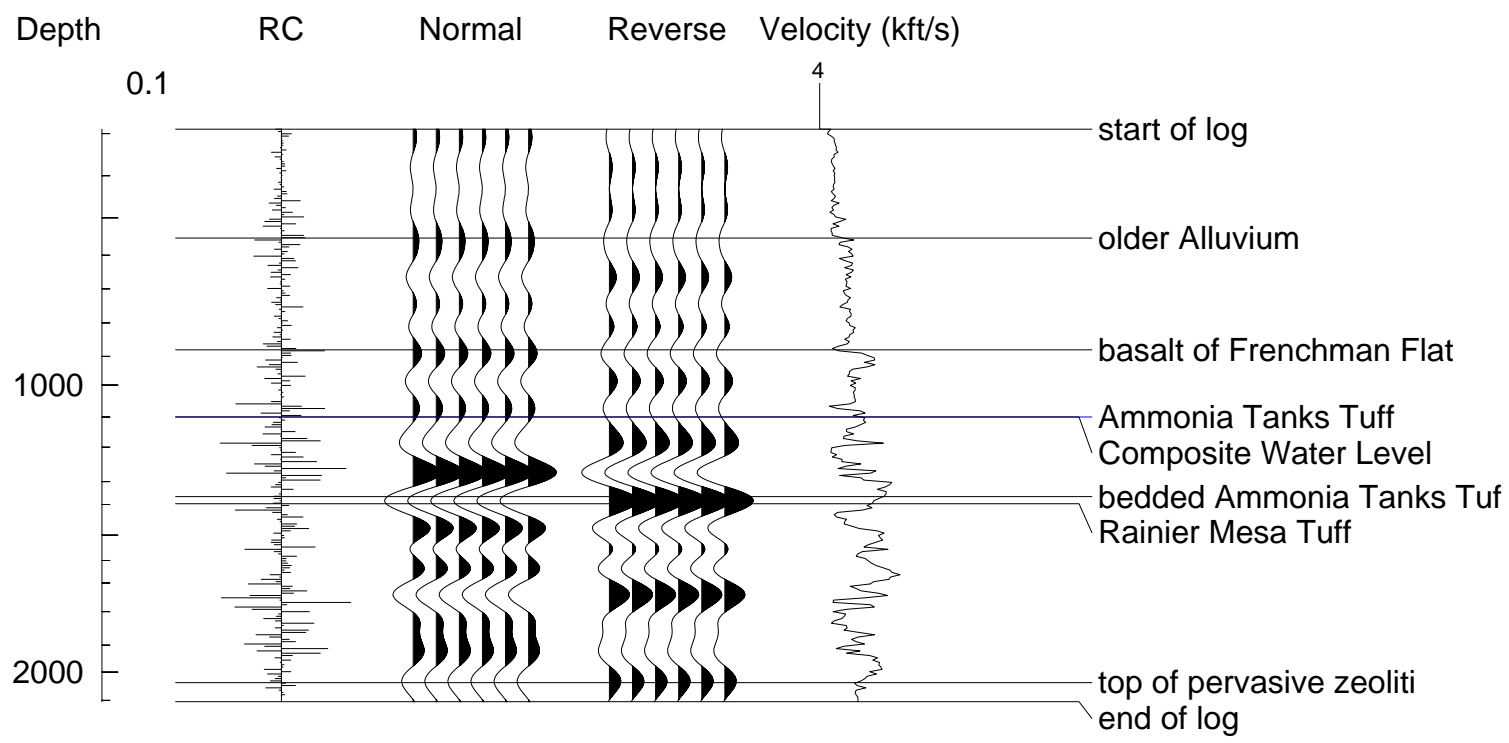

\begin{tabular}{|c|c|c|c|c|c|c|c|}
\hline start of log & 290 & 3137 & 0.140 & 4143 & & & \\
\hline older Alluvium & 550 & 2877 & 0.234 & 4693 & 260 & 0.094 & 5510 \\
\hline basalt of Frenchman Flat & 880 & 2547 & 0.331 & 5314 & 33 & $\frac{7}{0}$ & 6 \\
\hline Ammonia Tanks Tuff & 1100 & 2327 & 0.389 & 5650 & 220 & 0. & 15 \\
\hline Composite Water Level & 1100 & 2327 & 0.389 & 5650 & 268 & 000 & \\
\hline bedded Ammonia Tanks Tuf & 1368 & 2059 & 0.458 & 5967 & 200 & 0.069 & 1152 \\
\hline Rainier Mesa Tuff & 1398 & 2029 & 0.465 & 6017 & 30 & 0.006 & 9684 \\
\hline top of pervasive zeoliti & 2040 & 1387 & 0.619 & 6586 & 642 & 0.155 & 8295 \\
\hline end of log & 2104 & 1323 & 0.636 & 6617 & 64 & 0.017 & 7772 \\
\hline
\end{tabular}

Wavelet

5-10-25-30 Hz

Phase $=0$ degrees

Length $=0.200 \mathrm{Sec}$

QuickSyn @ 1996-2004 by GeoTools

Figure D.4-8

Synthetic Seismogram for UE-5i 


\section{UE-5k}

Synthetic from velocity log

$\mathrm{KB}=3349 \mathrm{ft} \quad \mathrm{GL}=3349 \mathrm{ft} \quad$ Datum $=3349 \mathrm{ft} \quad$ Datum Velocity $=5094 \mathrm{ft} / \mathrm{sec}$

Time scale $=5$ inches $/$ second $\quad$ Traces $/$ inch $=10 \quad$ AGC length $=$ None

Sample rate $=2 \mathrm{msec}$ Acoustic impedance from sonic log

Date plotted: 09-07-2004 Measurement Units: Feet

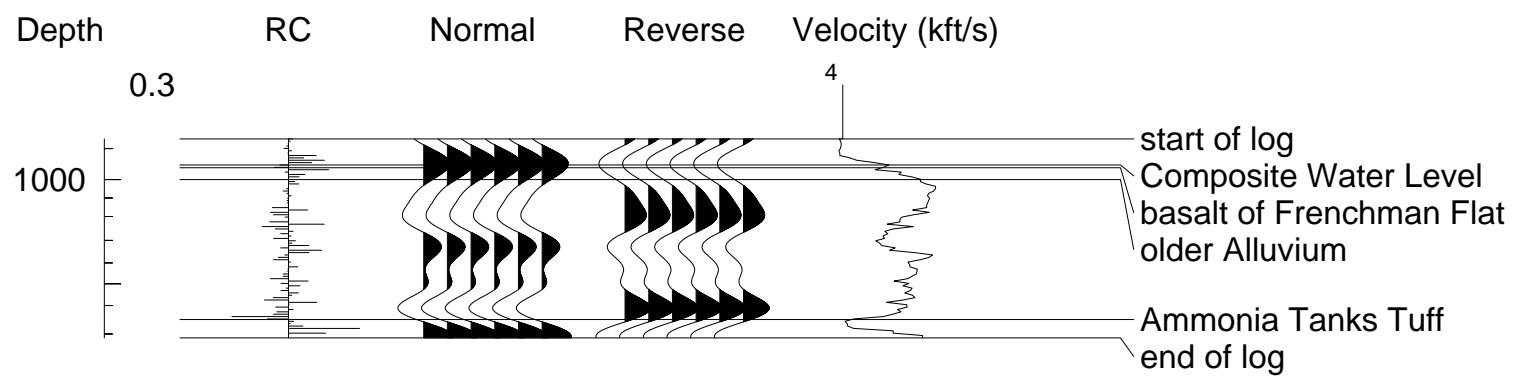

\begin{tabular}{|c|c|c|c|c|c|c|c|}
\hline start of log & 880 & 2469 & 0.346 & 5094 & & \\
\cline { 1 - 4 } Composite Water Level & 939 & 2410 & 0.368 & 5110 & 59 & 0.022 & 5355 \\
\hline basalt of Frenchman Flat & 950 & 2399 & 0.370 & 5136 & 11 & 0.002 & 9270 \\
\hline older Alluvium & 1000 & 2349 & 0.380 & 5264 & 50 & 0.010 & 9982 \\
\hline Ammonia Tanks Tuff & 1660 & 1689 & 0.498 & 6666 & 660 & 0.118 & 11176 \\
\hline end of log & 1719 & 1630 & 0.514 & 6695 & 59 & 0.015 & 7614 \\
\hline
\end{tabular}

Wavelet

5-10-25-30 Hz

Phase $=0$ degrees

Length $=0.200 \mathrm{Sec}$

QuickSyn @ 1996-2004 by GeoTools

\section{Figure D.4-9}

Synthetic Seismogram for UE-5k 


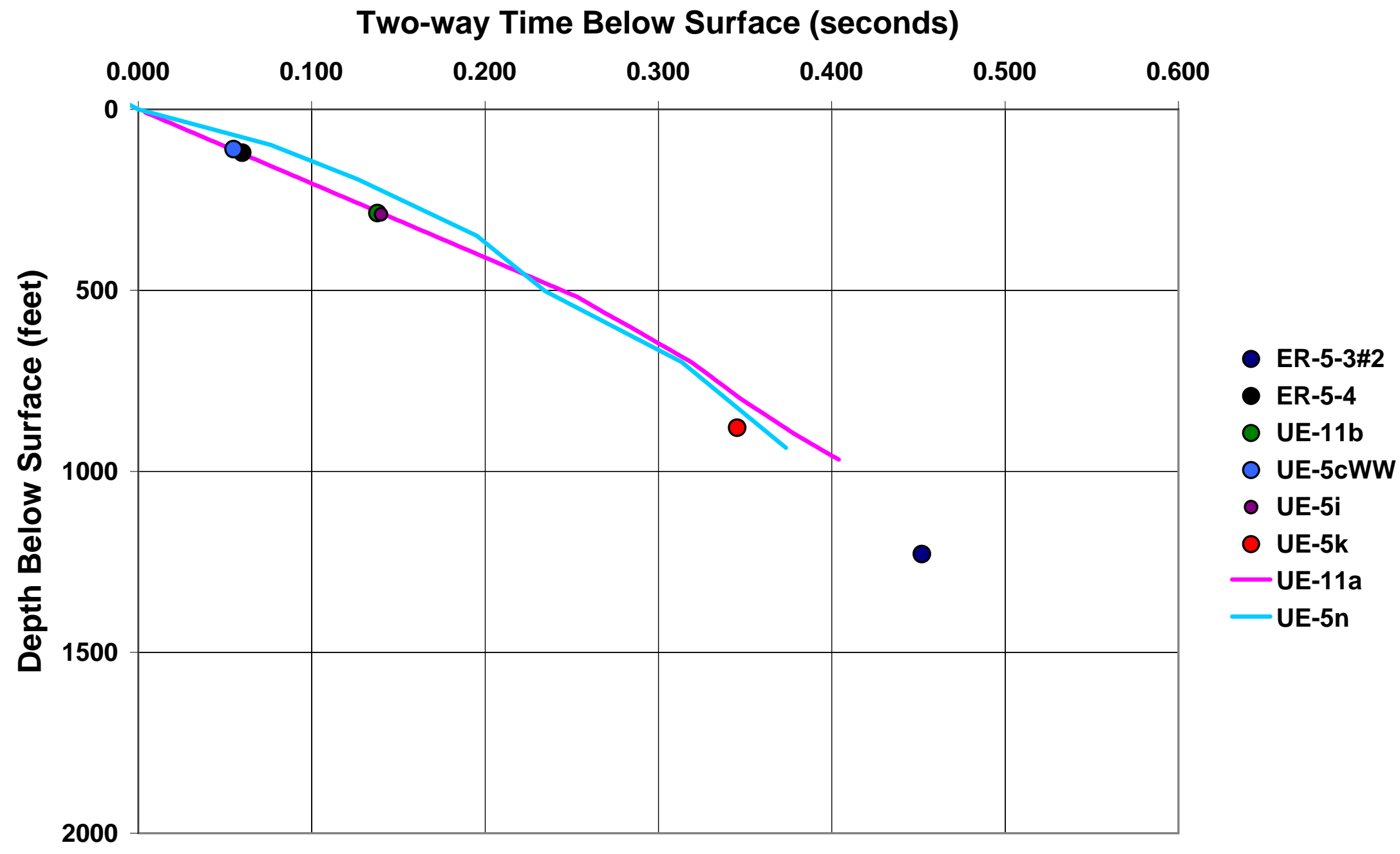

Figure D.4-10

Estimated Time Values for Starting Depths of Logs Used to Construct Time-Depth Curves for the Frenchman Flat 3-D Seismic Survey. Solid lines are time depth curves for UE-11a and UE-5n based on Check Shot Surveys. 


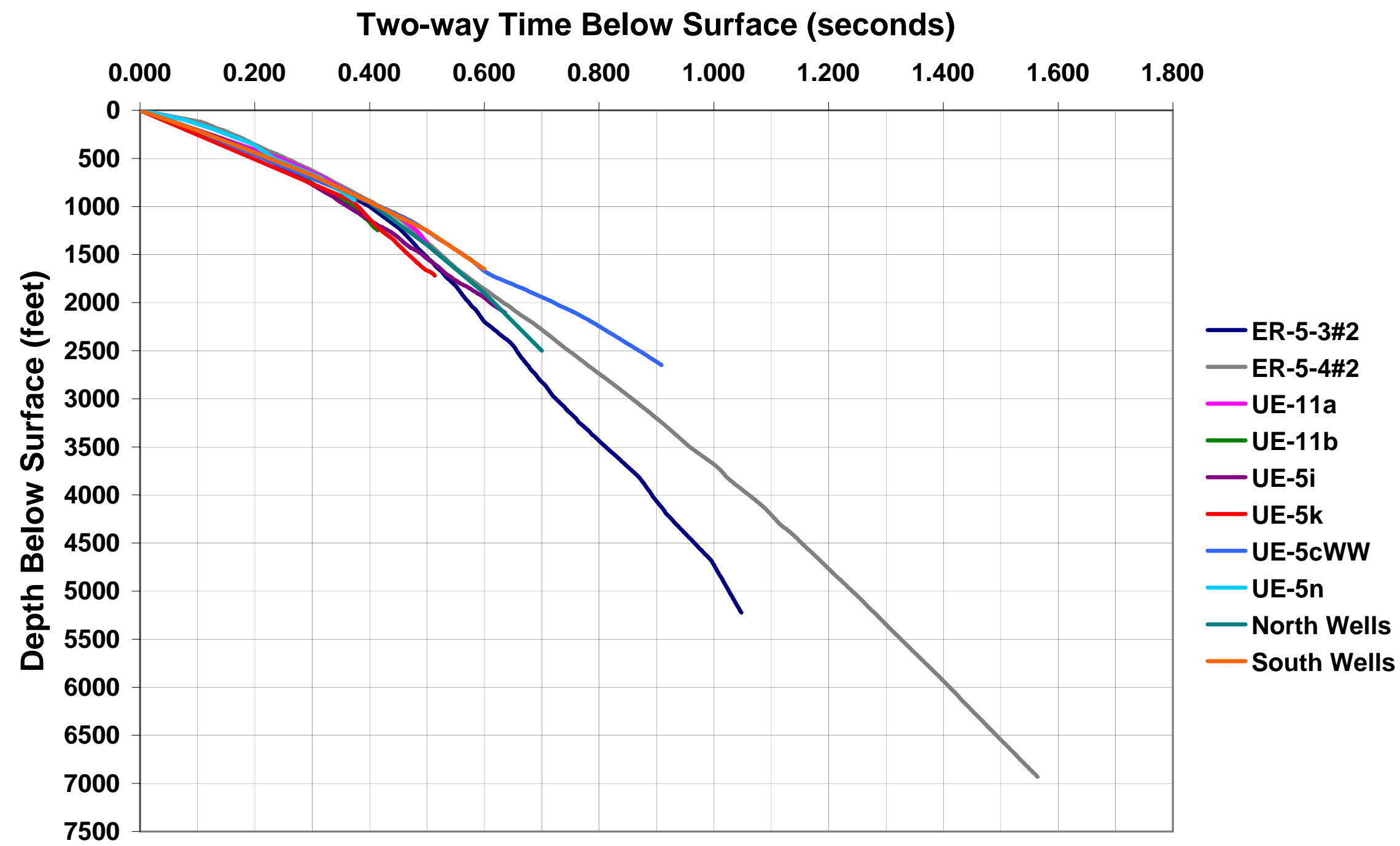

Figure D.4-11

Time-Depth Curves Utilized for the Frenchman Flat 3-D Seismic Survey. 


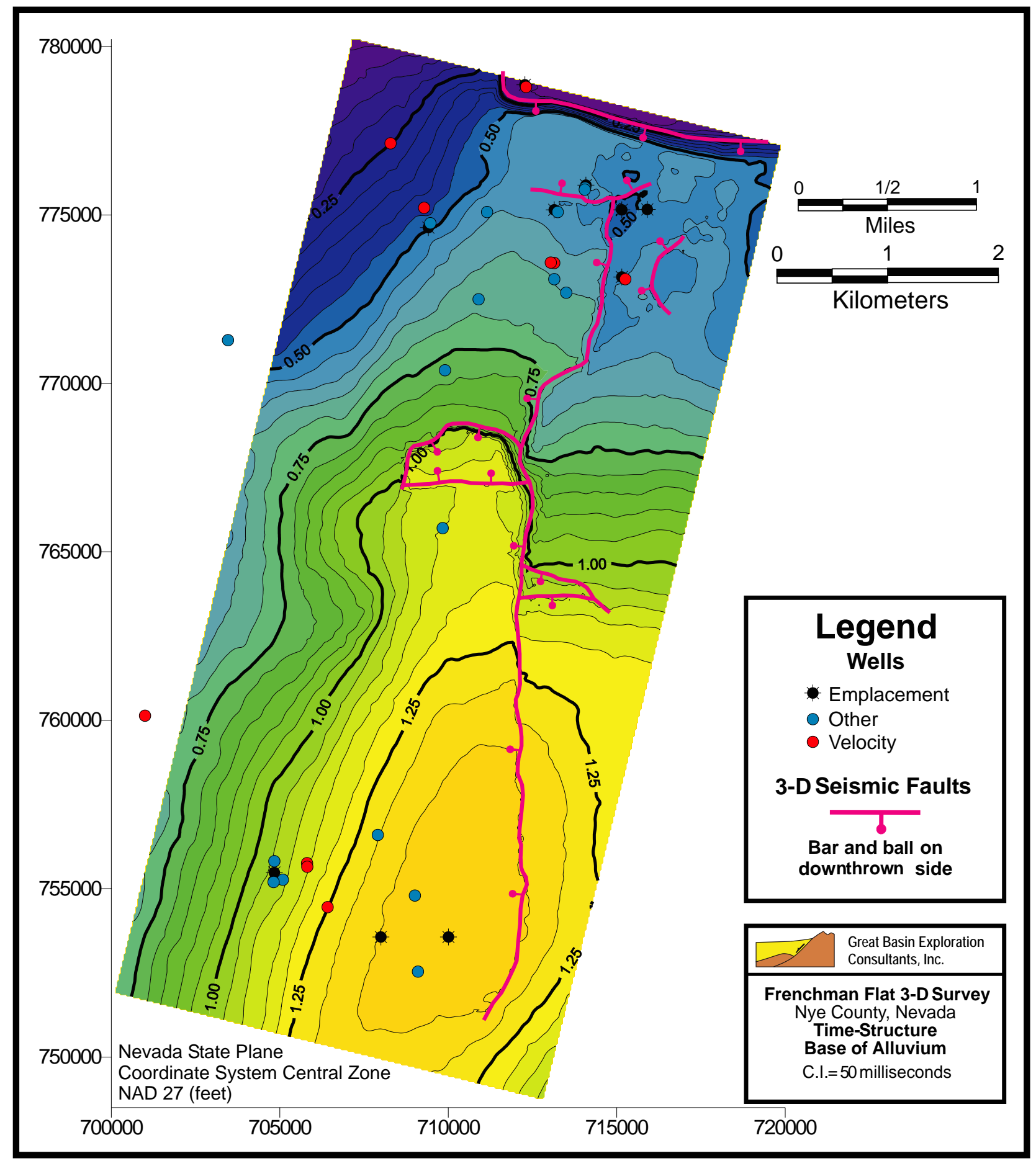

Figure D.4-12

Time-Structure Map for Base of Alluvium (BOA) 


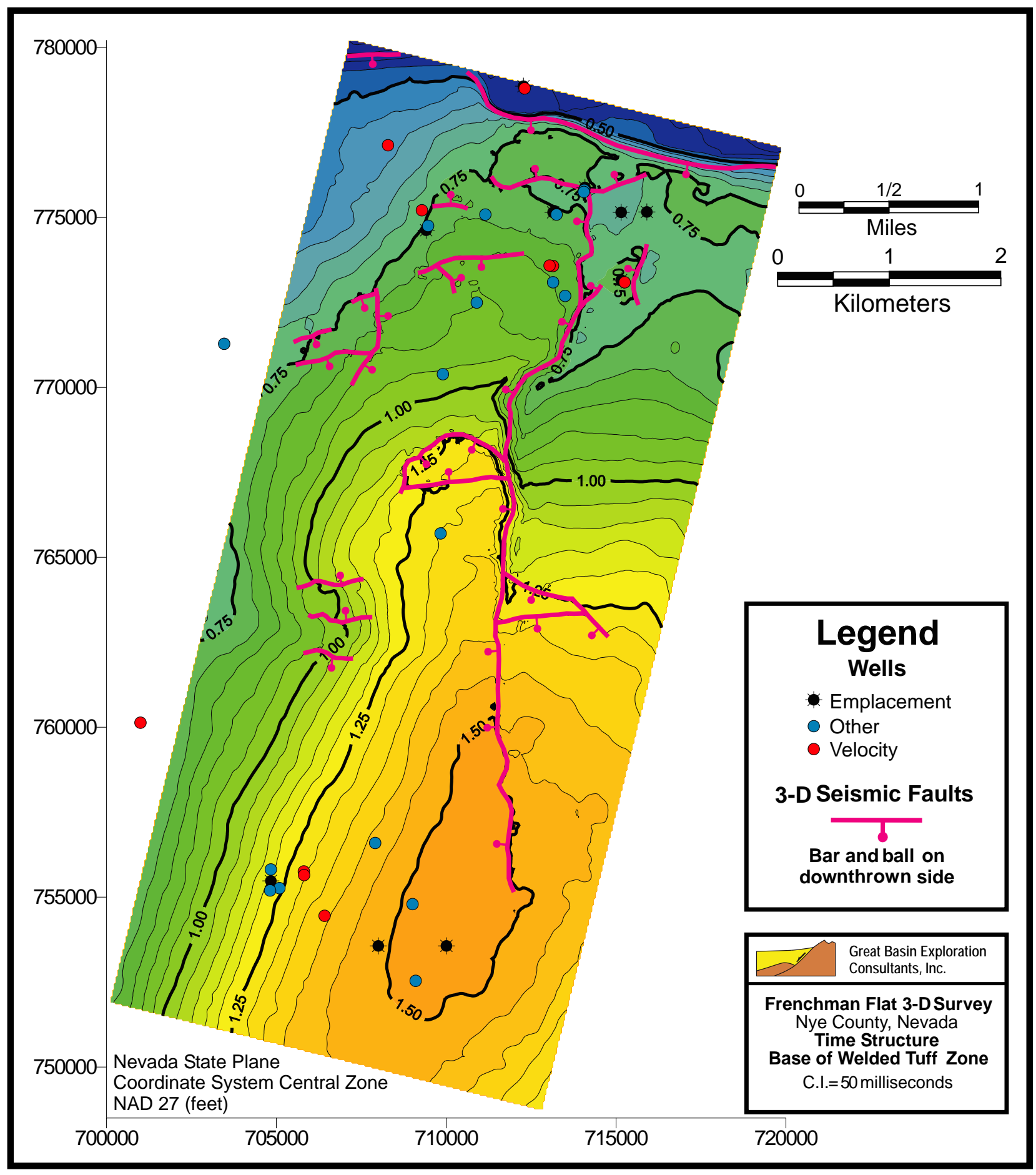

Figure D.4-13

Time-Structure Map for Base of Welded Zone (BWZ) 


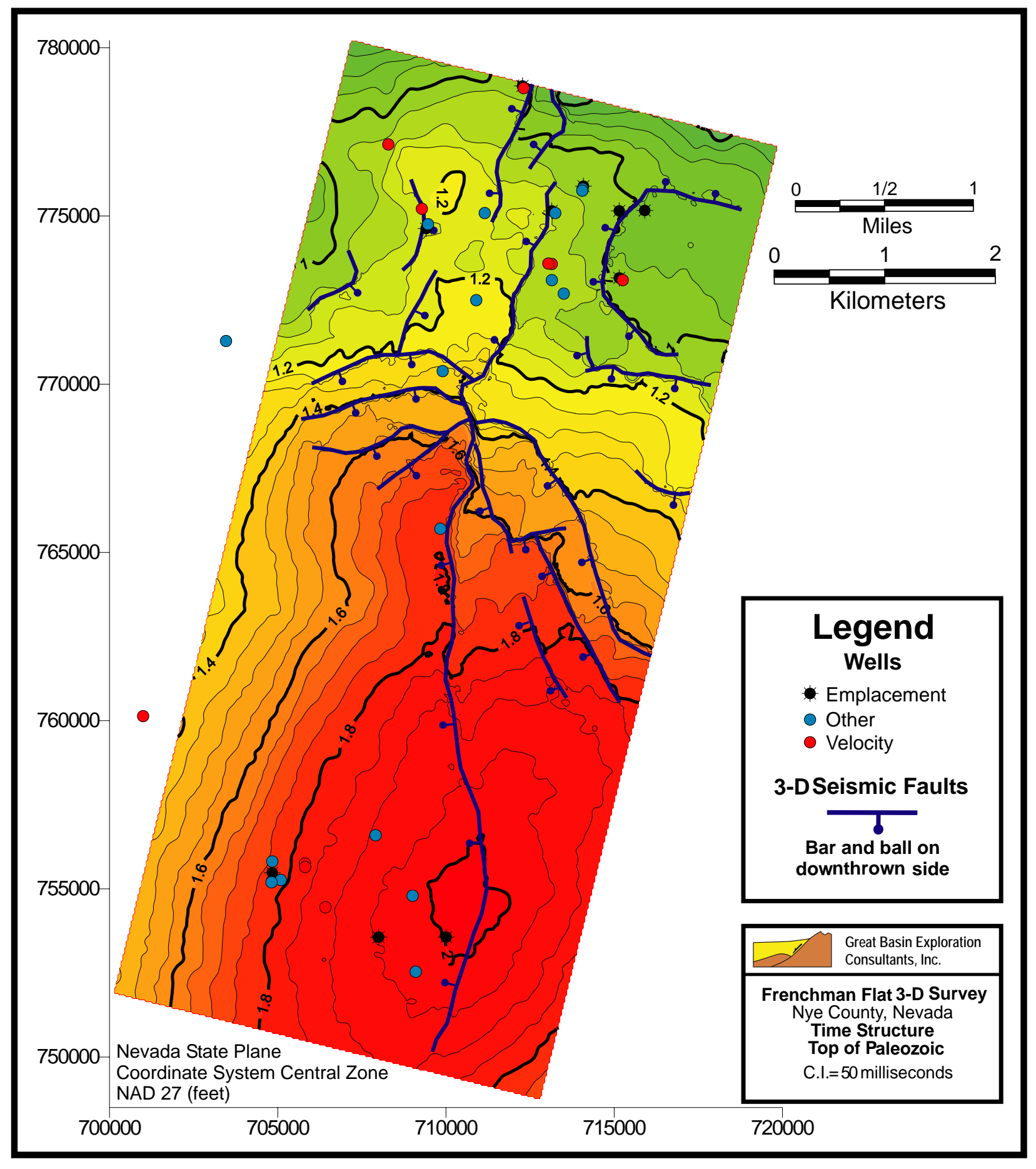

Figure D.4-14

Time-Structure Map for Top of Paleozoic Rocks (Pz) 


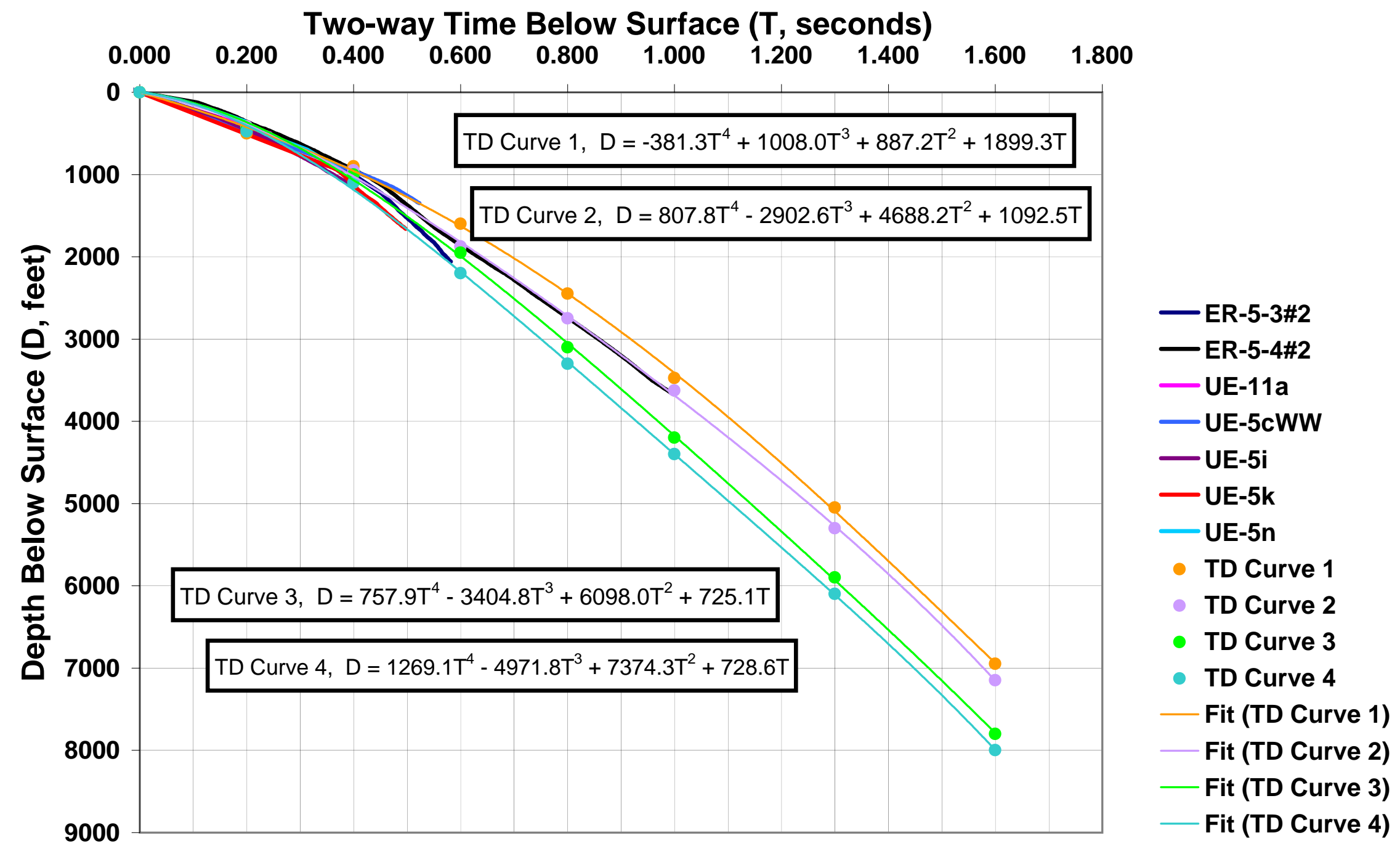

Figure D.4-15

Time-Depth (TD) Curves for Alluvium 


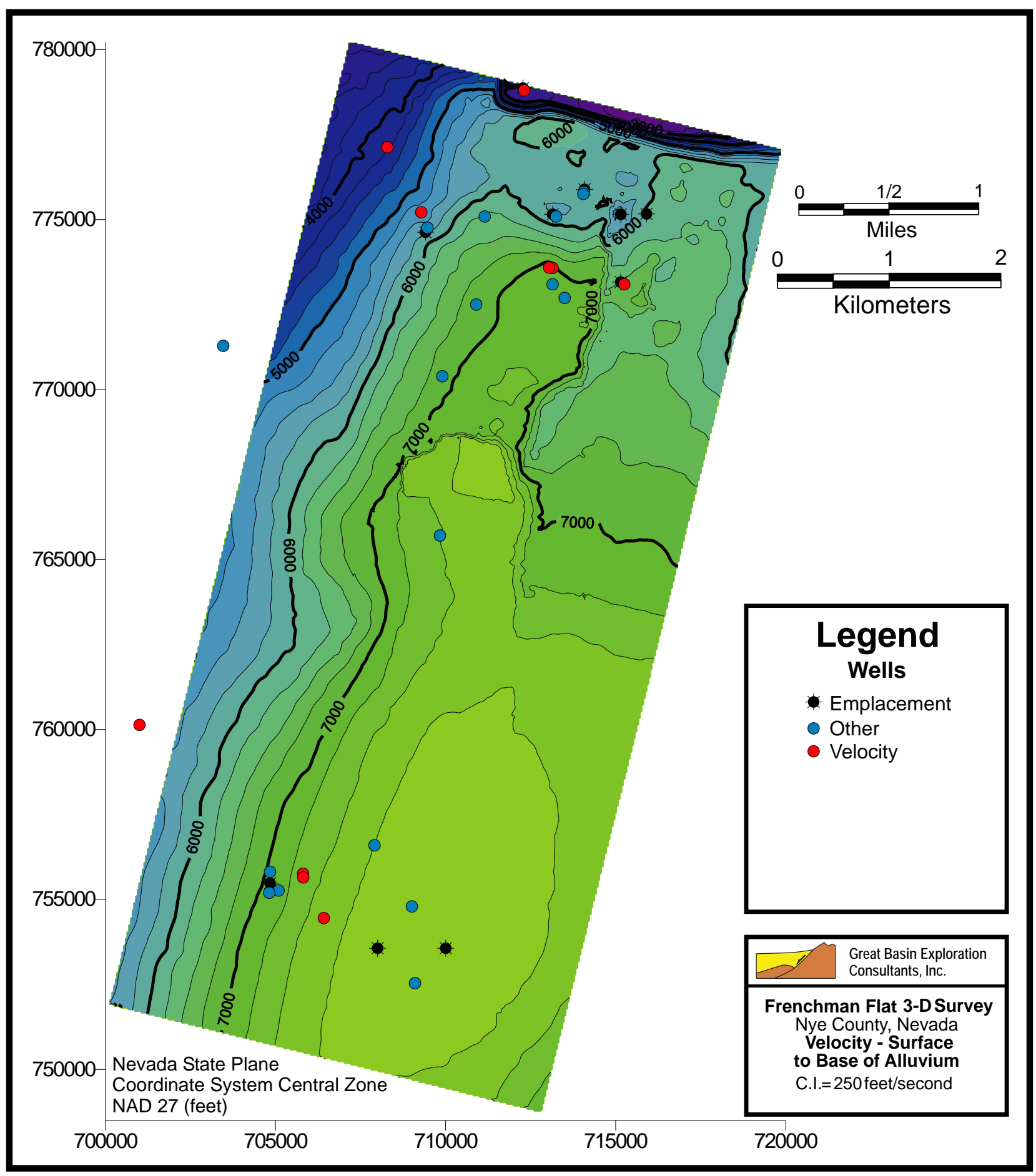

Figure D.4-16

Velocity Map from Surface to Base of Alluvium (BOA) 


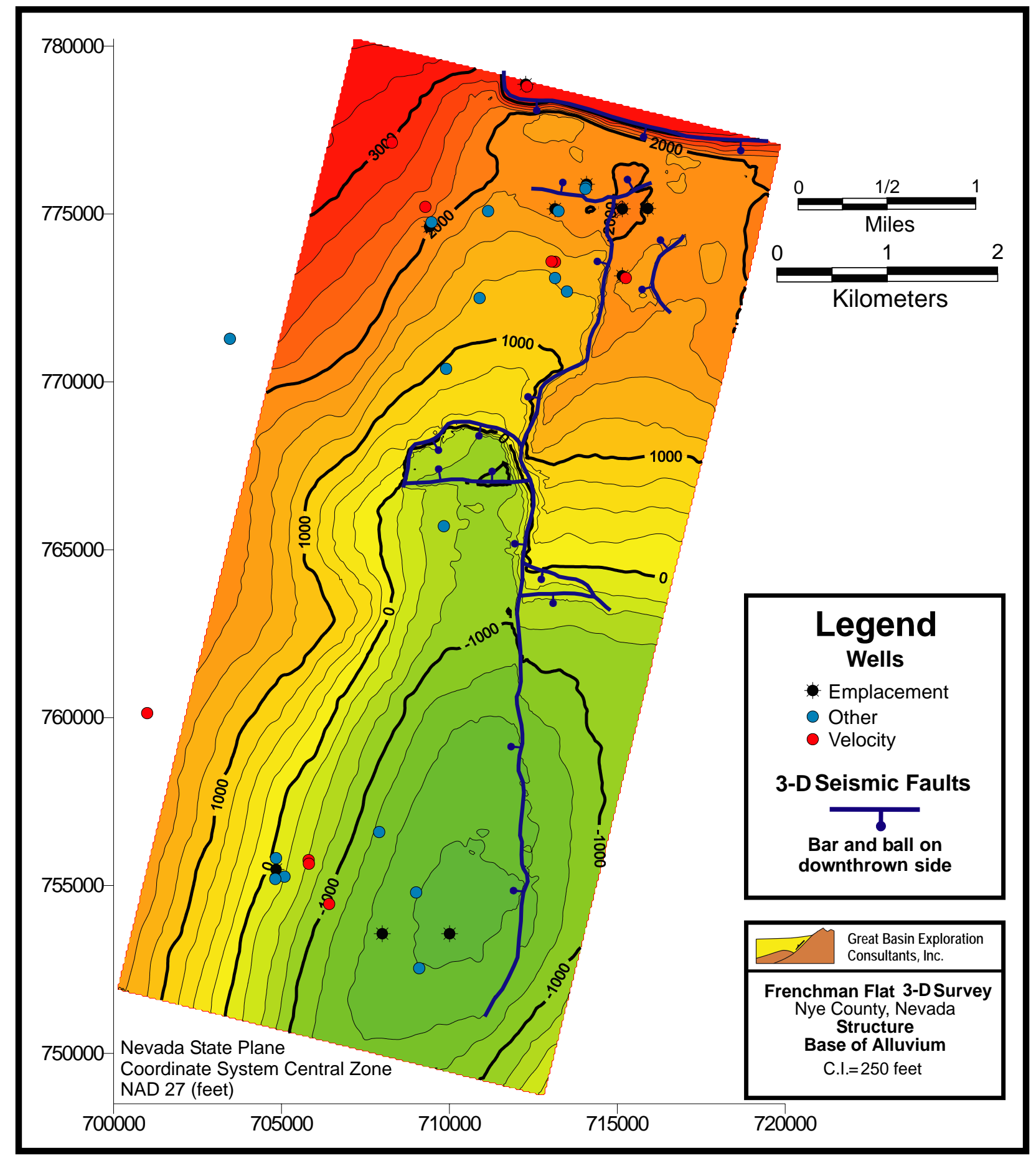

Figure D.4-17

Structure Map of the Base of Alluvium (BOA) 


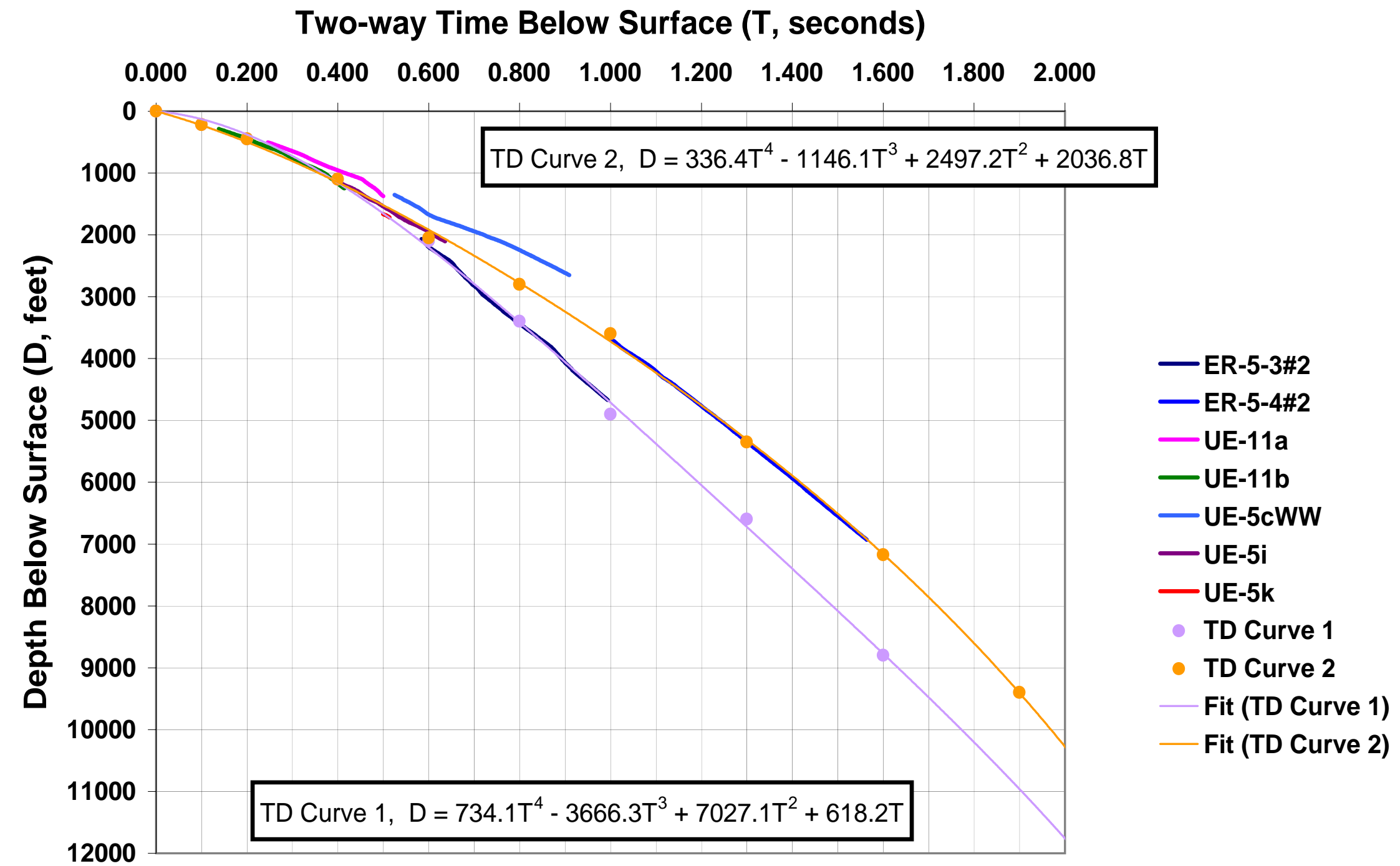

Figure D.4-18

Time-Depth (TD) Curves for Volcanic Rocks 


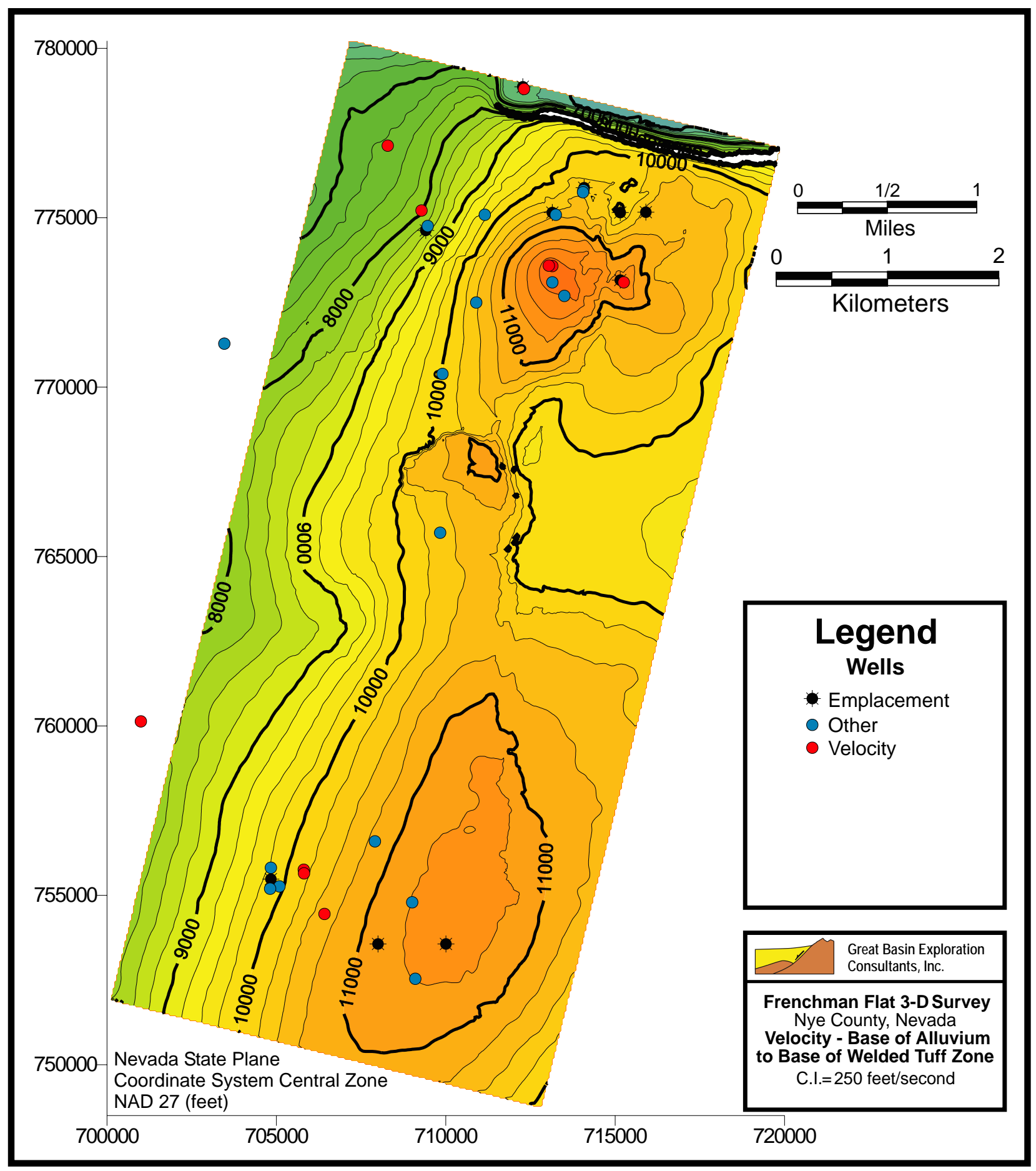

Figure D.4-19

Velocity Map from the Base of Alluvium (BOA) to Base of Welded Zone (BWZ) 


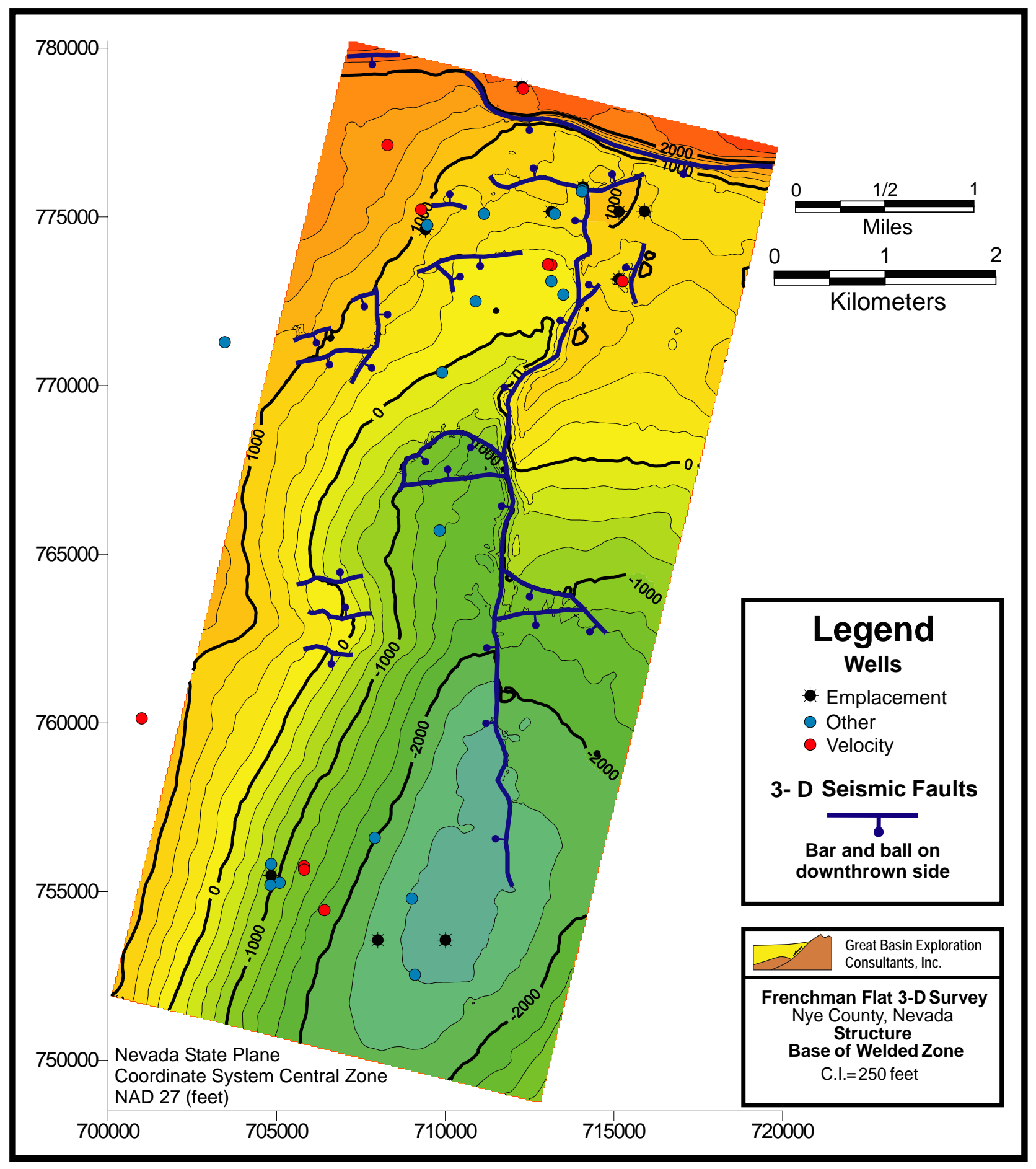

Figure D.4-20

Structure Map of the Base of Welded Zone (BWZ) 


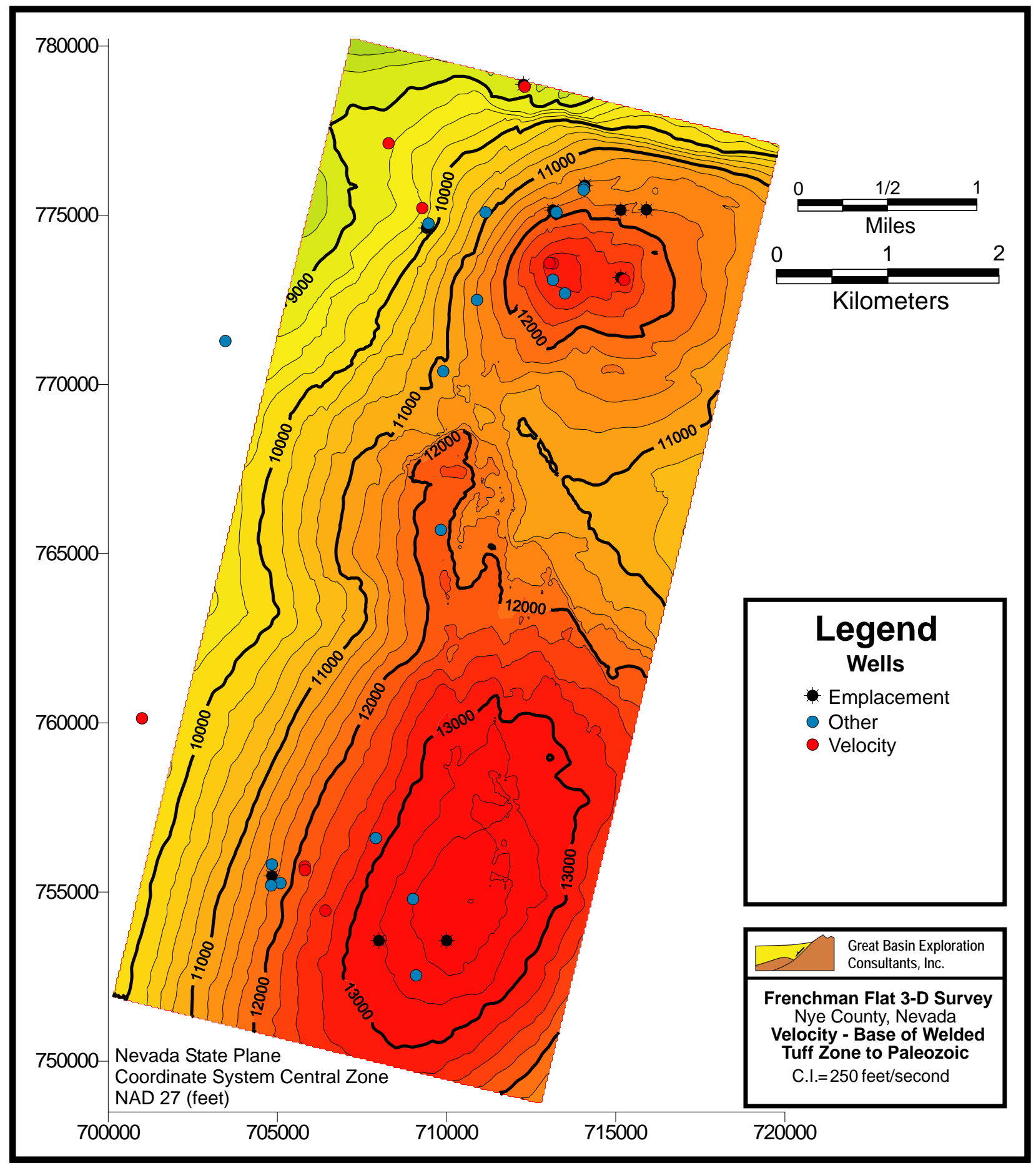

Figure D.4-21

Velocity Map from Base of Welded Zone (BWZ) to Top of Paleozoic Rocks (Pz) 


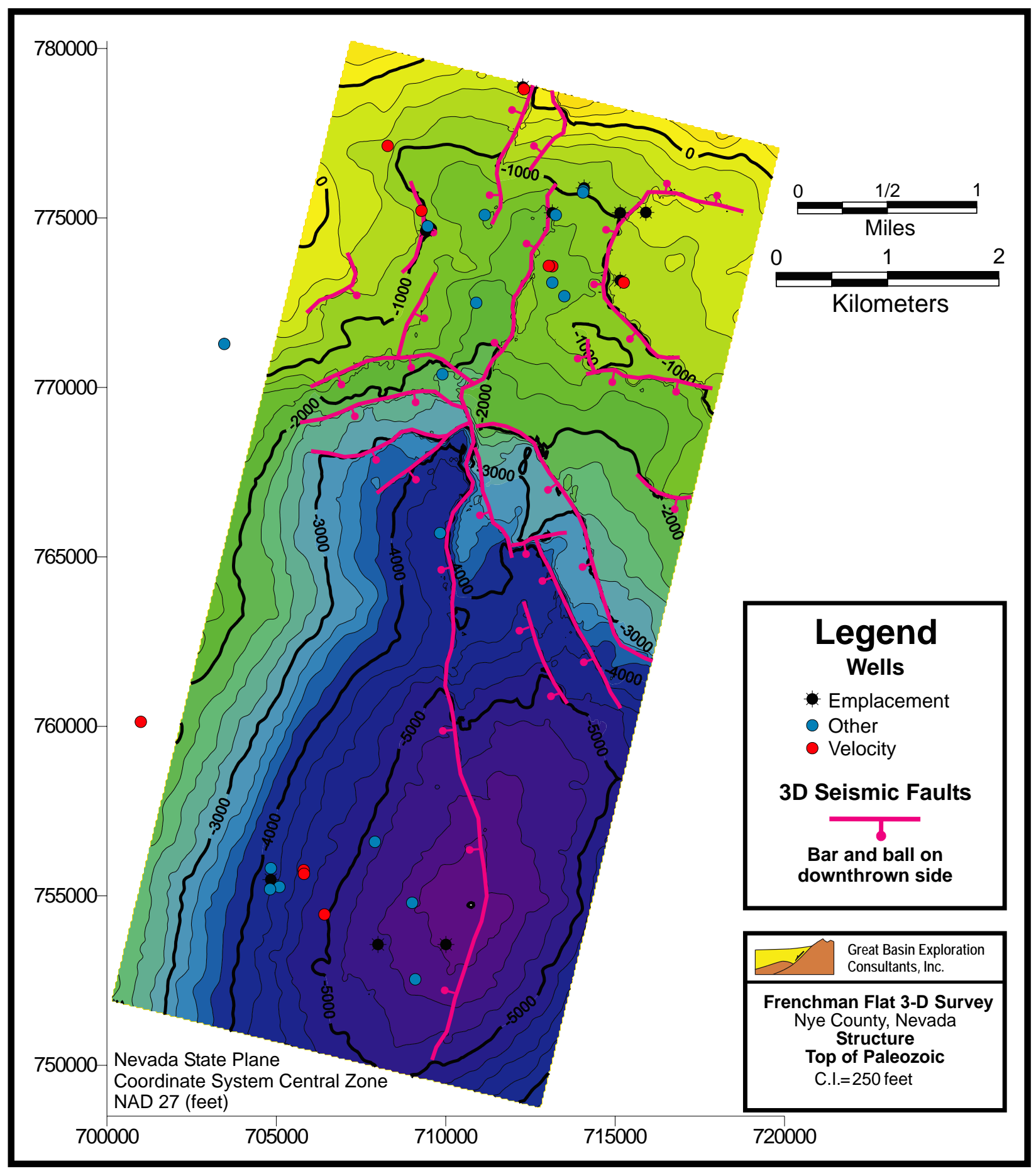

Figure D.4-22

Structure Map of the Top of Paleozoic Rocks (Pz) 


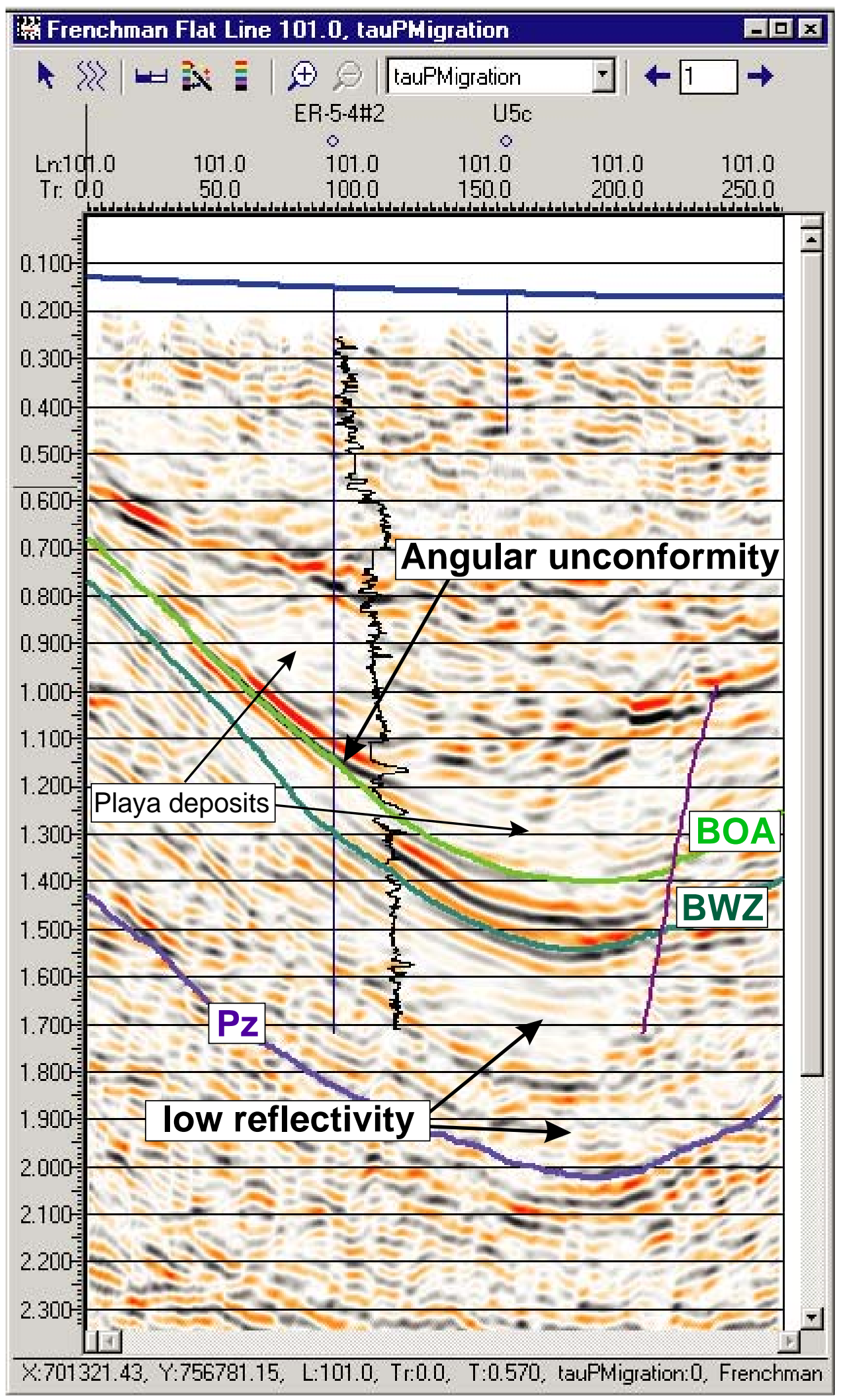

Figure D.4-23

Interpreted Seismic Profile along Inline 101, Looking North. (Log shown is velocity log for ER-5-4\#2) 


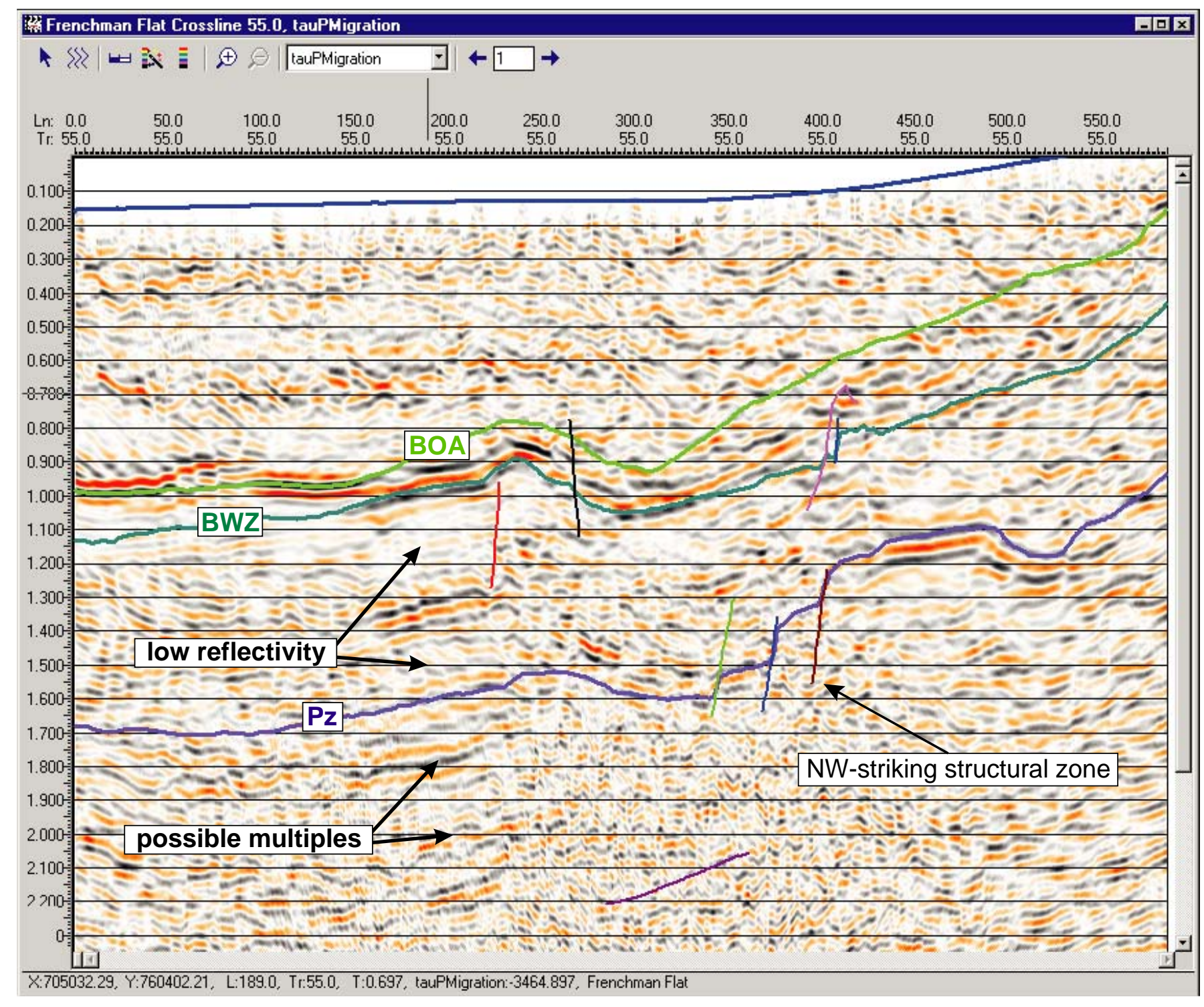

Figure D.4-24

Interpreted Seismic Profile Along Crossline 55, Looking West 


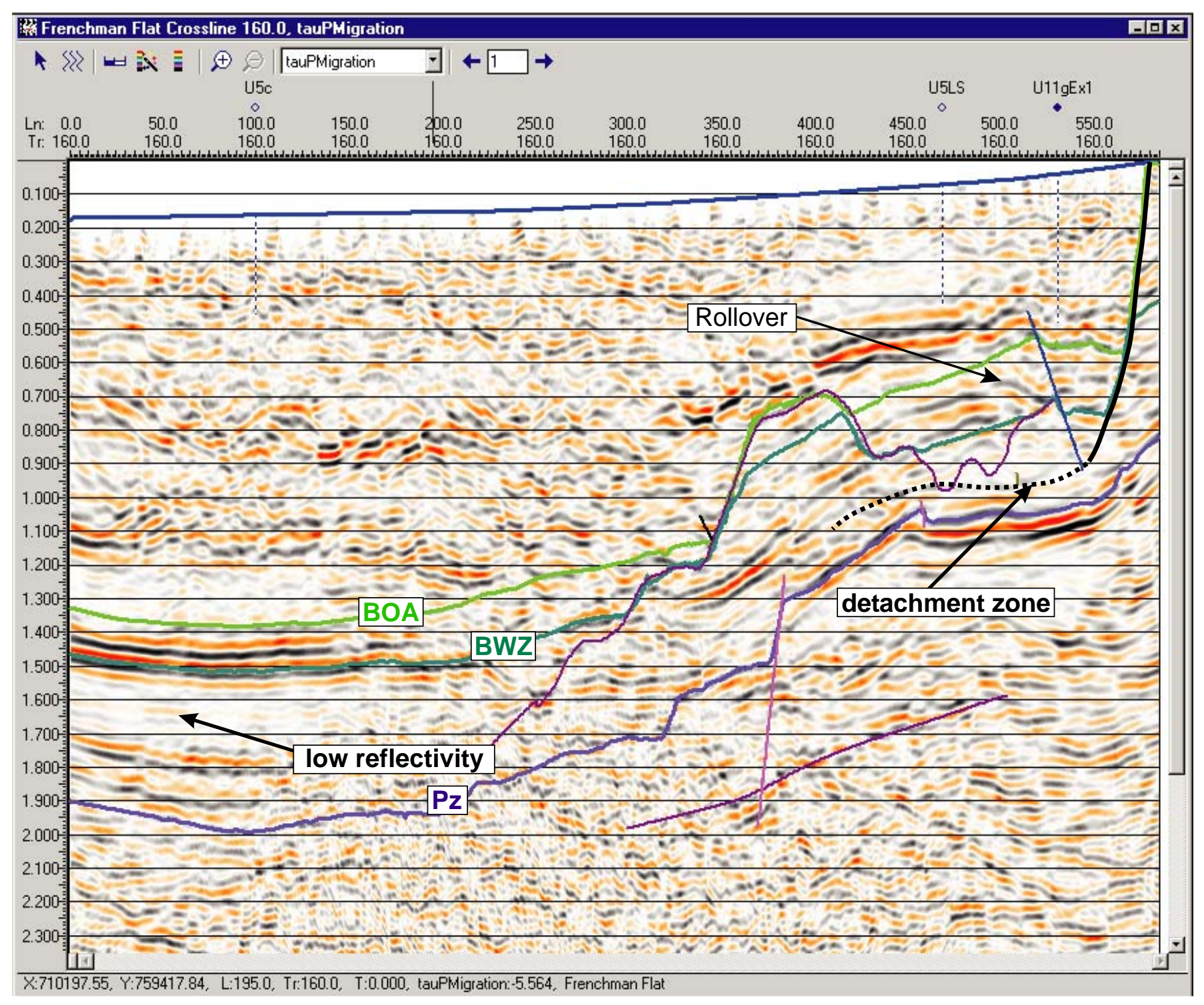

Figure D.4-25

Interpreted Seismic Profile Along Crossline 160, Looking West. 


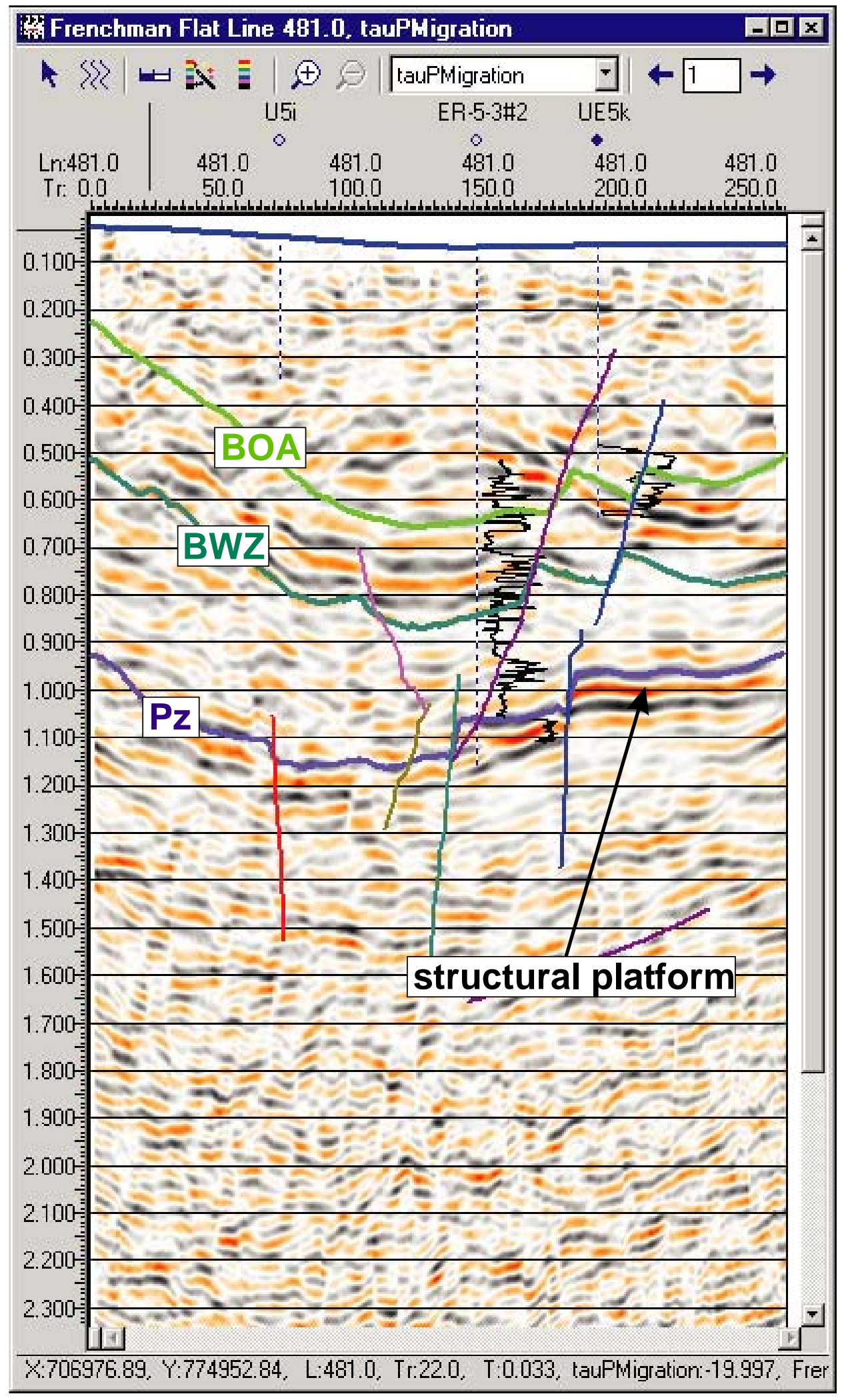

Figure D.4-26

Interpreted Seismic Profile Along Inline 481, Looking North (Logs shown are velocity logs for ER-5-3\#2 and UE-5k) 


\section{D.5.0 Summary}

A 3-D seismic reflection survey was conducted in Frenchman Flat to provide subsurface geologic information to better constrain groundwater flow and contaminant transport models. Three seismic horizons were mapped and include from highest to lowest, 1) the base of the alluvial basin-fill deposits (BOA), 2) the base of a zone of Tertiary-age welded ash-flow tuffs (BWZ), and 3) the top of Paleozoic-age sedimentary rocks (Pz). The mapping of these three horizons effectively delineates the extent, thickness, and structural orientation of the alluvial and volcanic aquifers. In addition, mapping of the BWZ and $\mathrm{Pz}$ improves constraints on the extent and thickness of the tuff and volcaniclastic confining units that occur between these two horizons. The Pz surface corresponds to the top of the regional carbonate aquifer and thus improves constraints on the depth to and structural orientation of this important aquifer.

Seismic data also revealed the presence of two large and previously unknown structures. A northwest-striking fault zone was identified that separates the Frenchman Flat basin proper from a structural platform on the north. In addition, the seismic data in conjunction with drill hole and outcrop data strongly suggest that much of the northern structural platform overlies a detachment fault within the volcanic rocks.

Results from the interpretation of the Frenchman Flat 3-D seismic data will allow for much more accurate modeling of hydrostratigraphic units in the survey area. Interpretation results also significantly improve and better constrain the structural model of the basin. The improved accuracy and better constraints provided by the seismic data will allow for more realistic evaluation of potential short-circuit groundwater pathways. 
This Page Intentionally Left Blank.

D-5-2 


\section{D.6.0 References}

Barnes, H., E. B. Ekren, C. L. Rodgers, and D. C. Hedlund. 1982. Geology and Tectonic Maps of the Mercury Quadrangle, Nye and Clark Counties, Nevada. U.S. Geological Survey, Miscellaneous Geologic Investigations Series Map I-1197, scale 1:24,000.

Carr, W. J., G. D. Bath, D. L. Healey, and R. M. Hazlewood. 1975. Geology of Northern Frenchman Flat, Nevada Test Site, U.S. Geological Survey Report, USGS-474-216.

Grauch, V. J. S., and M. R. Hudson. 1995. Preliminary Analysis of Major Structures and Lithologic Boundaries for the Frenchman Flat Model Area. Denver, CO: U.S. Geological Survey.

Hinrichs, E. N. 1968. Geologic Map of the Camp Desert Rock Quadrangle, Nye County, Nevada. U. S. Geological Survey Quadrangle Map G-726, scale 1:24,000.

Hinrichs, E. N., and E. J. McKay. 1965. Geologic Map of the Plutonium Valley Quadrangle, Nye and Lincoln Counties, Nevada, U.S. Geological Survey Geologic Quadrangle Map 384, scale 1:24,000.

McKeown, F.A., D.L. Healey, and C.H. Miller. 1976. Geologic Map of the Yucca Lake Quadrangle, Nye County, Nevada. U.S. Geological Survey GQ-1327, scale 1:24,000.

Nevada Bureau of Mines and Geology, 1996. County Digital Geologic Mapping Project- Final Report. Open-File Report 97-1. Scale 1:250,000.

Poole, F. G. 1965. Geologic Map of the Frenchman Flat Quadrangle, Nye, Lincoln, and Clark Counties, Nevada, U.S. Geological Survey Geologic Quadrangle Map GC-456, scale $1: 24,000$.

Poole, F.G., D.P. Elston, and W.J. Carr. 1965. Geologic Map of the Cane Spring Quadrangle, Nye County, Nevada. U.S. Geological Survey Geologic Quadrangle Map GQ-455, scale $1: 24,000$.

Prothro, L. B., 2002. Written communication. Subject: Geologic Interpretation of the Frenchman Flat 3-D Seismic Data. Bechtel Nevada. Las Vegas, NV.

Prothro, L.B., and S.L. Drellack, Jr. 1997. Review and Reconnaissance of the Hydrogeology of Tertiary Sedimentary Rocks in the Vicinity of Frenchman Flat, Nevada Test Site. DOE/NV/11718-155. Las Vegas, NV: Bechtel NV. 
Slate, J. L., M. E. Berry, P. D. Rowley, C. J. Fridrich, K. S. Morgan, J. B. Workman, O. D. Young, G. L. Dixon, V. S. Williams, E. H. McKee, D. A. Ponce, T. G. Hildenbrand, WC Swadley, S. C. Lundstrom, E. B. Ekren, R. G. Warren, J. C. Cole, R. J. Fleck, M. A. Lanphere, D. A. Sawyer, S. A. Minor, D. J. Grunwald, R. J. Laczniak, C. M. Menges, J. C. Yount, and A. S. Jayko, 1999. Digital Geologic Map of the Nevada Test Site and Vicinity, Nye, Lincoln, and Clark Counties, Nevada, and Inyo County, California. U.S. Geological Survey Open-File Report 99-554-A, scale 1:120,000.

Twiss R. J. and E. M. Moores, 1992. Structural Geology. W. H. Freeman and Company, New York, $530 \mathrm{pp}$. 


\section{Plate 1}

\section{Surface Geologic Map of Frenchman Flat and Vicinity}




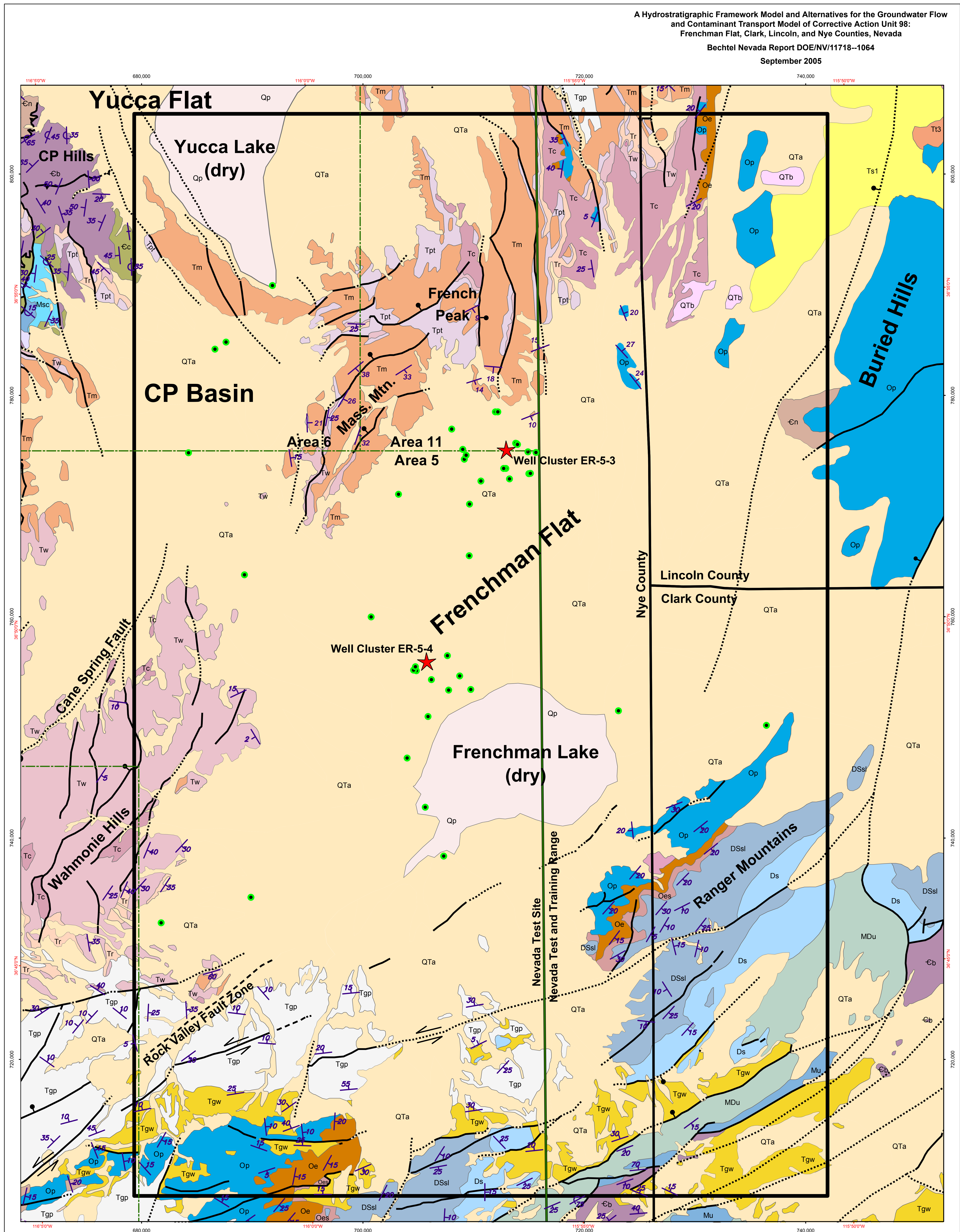

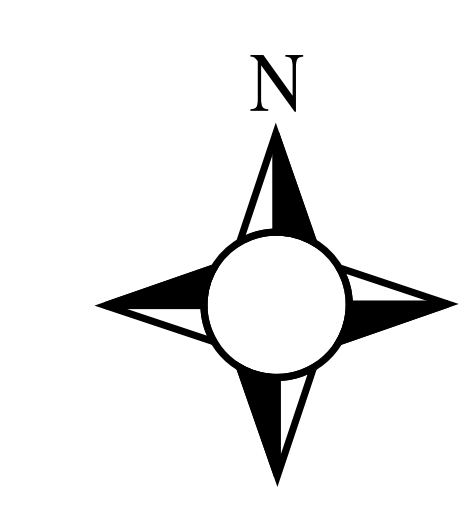

Geology

QTa Quaternary/Tertiary alluvium

Qp Playa deposits

lava flows, undivided

Tm Tuffs of the Timber Mountain Group

Tw Thopah Spring Tuf

Salyer Formation, undivided

Tc Tuffs of the Crater Flat Group

Tt3 Ash-flow tuffs and interbedded

QTb Basaltic lava flows, undivided

Tgp Rocks of Pavits Spring

ts1 1 Sedis of Winapi Wash
Plate 1

\section{Geologic Map of Frenchman Flat and Vicinity \\ (modified from Workman et al., 2002)}

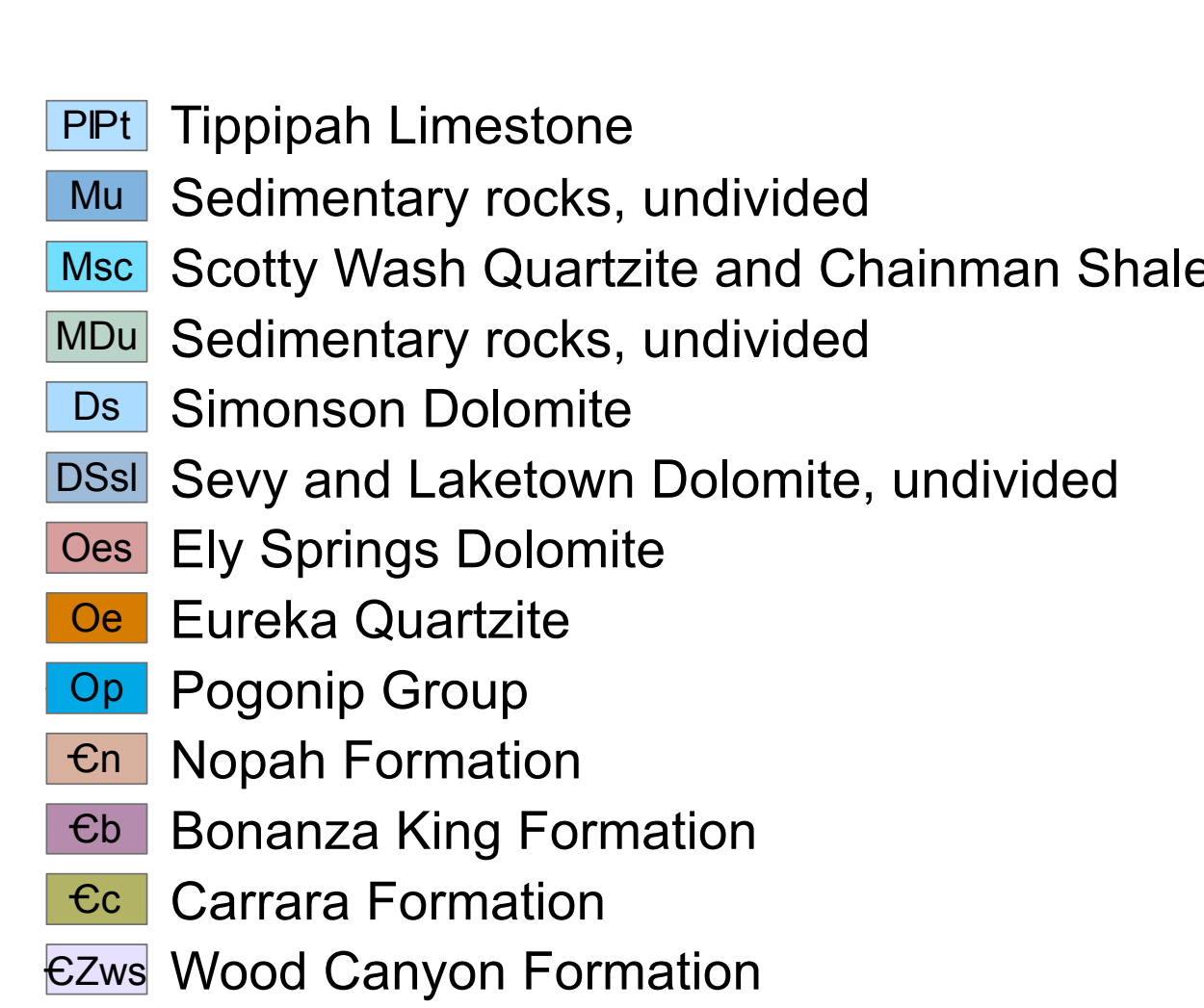

$\square$ Frenchman Flat CAU Model Boundary

Well Clusters ER-5-3 and ER-54

Strike and dip of bedding (Hinrichs \& McKay, 1965 Geologic fault structures

(from Workman et al., 2002)

- Fault-certain

Thrust fault

bar and ball symbol (ball on downthrown side) 0 气lateral offset arrows 


\section{Plate 2}

Hydrostratigraphic Surface Map of the Frenchman Flat Model Area 


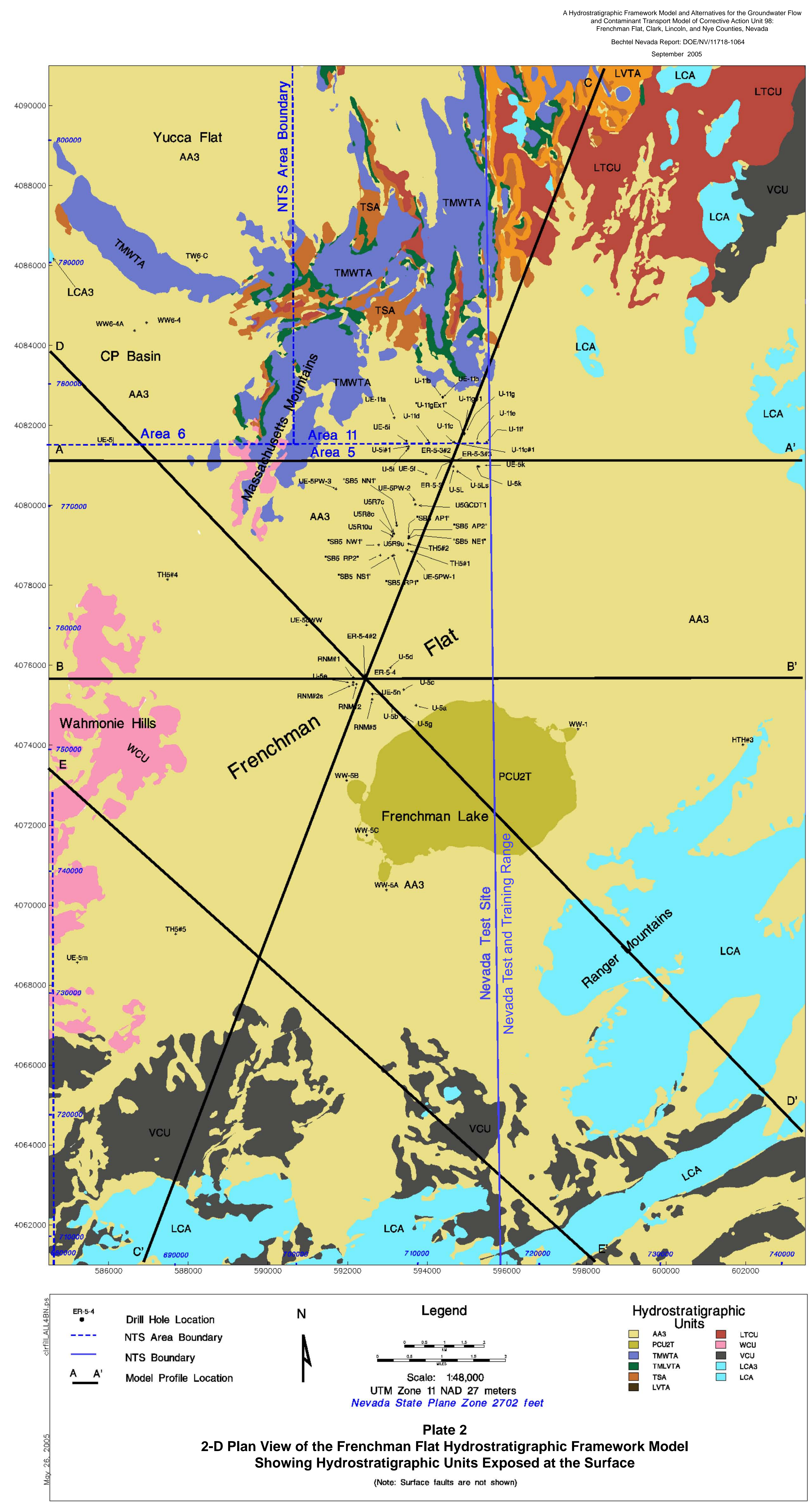

